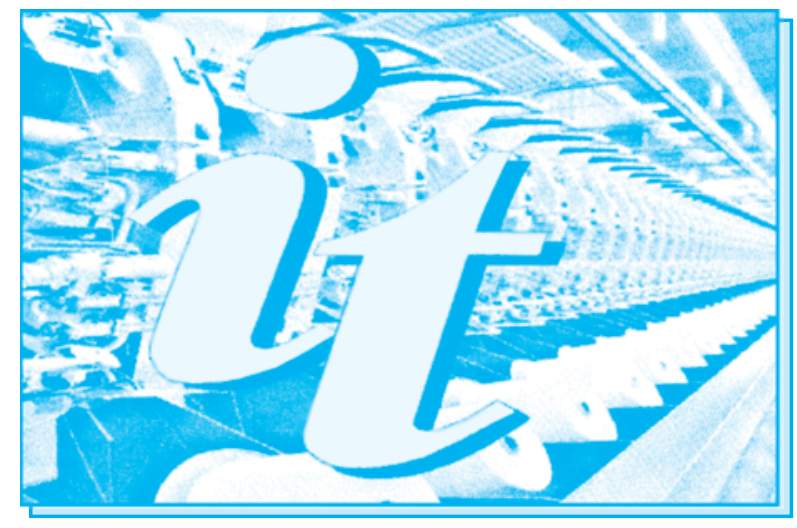

Revistă cotată ISI și inclusă în Master Journal List a Institutului pentru Știința Informării din Philadelphia - S.U.A., începând cu vol. 58, nr. 1/2007/

ISI rated magazine, included in the ISI Master Journal List of the Institute of Science Information, Philadelphia, USA, starting with vol. 58, no. 1/2007

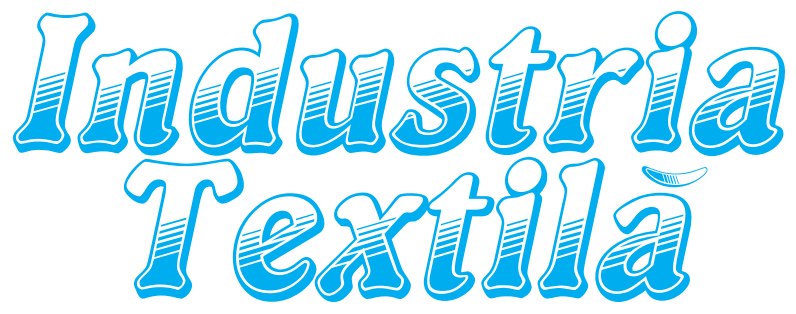

ISSN 1222-5347

$1 / 2017$

Editată în 6 nr./an, indexată și recenzată în:

Edited in 6 issues per year, indexed and abstracted in: Science Citation Index Expanded $\left(\mathrm{SciSearch}^{\circledR}\right)$, Materials Science Citation Index ${ }^{\circledR}$, Journal Citation Reports/Science Edition, World Textile Abstracts, Chemical Abstracts, VINITI, Scopus, Toga FIZ technik ProQuest Central

\section{COLEGIUL}

\section{DE REDACTIE:}

Dr. ing. CARMEN GHITULEASA CS I- DIRECTOR GENERAL

Institutul Naţional de Cercetare-Dezvoltare pentru Textile şi Pielărie - Bucureşti

\section{Dr. ing. EMILIA VISILEANU} CS I - EDITOR ŞEF

Institutul Naţional de Cercetare-Dezvoltare pentru Textile şi Pielărie - Bucureşti

Conf. univ. dr. ing. MARIANA URSACHE DECAN

Facultatea de Textile-Pielărie şi Management Industrial, Universitatea

Tehnică „Ghe. Asachi“" - laşi

Prof. dr. GELU ONOSE CSI

Universitatea de Medicină şi Farmacie "Carol Davila" - Bucureşti

Prof. dr. ing. ERHAN ÖNER Marmara University - Turcia

Prof. dr. MUGE YUKSELOGLU Marmara University - Turcia

Prof. univ. dr. DOINA I. POPESCU Academia de Studii Economice - Bucureşti

Prof. univ. dr. ing. CARMEN LOGHIN Universitatea Tehnică "Ghe. Asachi“ - laşi

Prof. univ. dr. MARGARETA STELEA FLORESCU Academia de Studii Economice - Bucureşti

\section{Prof. ing. ARISTIDE DODU}

Membru de onoare al Academiei de Ştiinţe Tehnice din România

Prof. dr. ing. LUIS ALMEIDA University of Minho - Portugal

Prof. $d r$. LUCIAN CONSTANTIN HANGANU Universitatea Tehnică „Ghe. Asachi“" - laşi

\section{TATJANA ŠARAC, JOVAN STEPANOVIĆ, VASILIJE PETROVIĆ,} GORAN DEMBOSKI

Determinarea drapajului țesăturilor din bumbac

IOAN PAVEL OANA, DORINA OANA, MARIUS SUTEU, DAN MIRICESCU

Studiul proprietăţilor tensionale la firele de lână în amestec

cu elastomer, albite şi colorate

LINGJIE YU, RONGWU WANG, JINFENG ZHOU

Performanța metodei de evaluare a pilingului pe baza tehnicii DFF

IRENA FUNDUK, ALENKA PAVKO-ČUDEN

Caracteristici de contrucție, performanță și sociale ale rochiei de mireasă contemporane din Slovenia

SUKRAN KARA, SEVIL YESILPINAR, YAVUZ SENOL, TANER AKKAN

Design-ul echipamentului de navigație cu funcții electronice, pentru o siguranță îmbunătățită

JIE ZHANG, RURU PAN, WEIDONG GAO

Metoda de iluminare pentru inspecția precisă a desimii țesăturilor

\section{ZOUHAIER ROMDHANI, AYDA BAFFOUN, MOHAMED HAMDAOUI,} SADOK ROUDESLI

Comportamentul general şi parametrii care afectează fenomenul de imprimare cu jet de cerneală pe ţesătura de poliester

DERMAN VATANSEVER BAYRAMOL

Efectele turmalinei asupra răspunsului la tensiune al filamentelor PVDF

OVIDIU N. PENEŞ, ANDREI MIHAI NEAGU, FLAVIUS PLATA, SILVIU DUMITRU PĂUN

Țesături cu fir de argint având rol de control al contaminării bacteriene la pacienții în stare critică

LAI-LI WANG, XIONG-YING WU, XUE-MEI DING

Factori care afectează capacitatea de încărcare a pungilor de cumpărături din nețesute

GEORGETA POPESCU, SABINA OLARU, CLAUDIA NICULESCU

Design inovativ și simularea produselor de îmbrăcăminte pentru copiii cu modificări atipice ale conformației și ţinutei

\section{MAJA JANKOSKA, GORAN DEMBOSKI}

Comparație între proprietățile mecanice, tușeul și capacitatea de croire a țesăturilor din lână în amestec pentru îmbrăcămintea de exterior

Recunoscută în România, în domeniul Științelor inginerești, de către Consiliul Național al Cercetării Științifice din Învățământul Superior (C.N.C.S.I.S.), în grupa $\mathbf{A}$ /

Aknowledged in Romania, in the engineering sciences domain, by the National Council of the Scientific Research from the Higher Education (CNCSIS), in group $\boldsymbol{A}$ 


\section{Contents}

TATJANA ŠARAC, JOVAN STEPANOVIĆ, VASILIJE PETROVIĆ, GORAN DEMBOSKI

IOAN PAVEL OANA, DORINA OANA, MARIUS SUTEU, DAN MIRICESCU

LINGJIE YU, RONGWU WANG, JINFENG ZHOU

IRENA FUNDUK, ALENKA PAVKO-ČUDEN

SUKRAN KARA, SEVIL YESILPINAR, YAVUZ SENOL, TANER AKKAN

JIE ZHANG, RURU PAN,

WEIDONG GAO

ZOUHAIER ROMDHANI, AYDA BAFFOUN, MOHAMED HAMDAOUI,

SADOK ROUDESLI

DERMAN VATANSEVER BAYRAMOL

OVIDIU N. PENEŞ, ANDREI MIHAI NEAGU, FLAVIUS PLATA, SILVIU DUMITRU PĂUN

LAI-LI WANG, XIONG-YING WU, XUE-MEI DING

GEORGETA POPESCU, SABINA OLARU, CLAUDIA NICULESCU

MAJA JANKOSKA, GORAN DEMBOSKI
Cotton type fabric drape prediction 3

The study of strain proprieties of woolen yarns mixed with elastomer, bleached and coloured

Performance of the pilling evaluation method based on the technique of DFF

Constructional, performance and social characteristics of contemporary Slovenian wedding dress

Design of an electronically equipped sailing garment for improved safety

A backlighting method for accurate inspection of woven fabric density

General behavior and parameters affecting the Ink jet printing phenomenon on woven polyester fabric

Effects of tourmaline on the voltage response of PVDF filaments

Fabric with silver thread role in the control of bacterial contamination in critically ill patients

Factors affect the carrying capacity of non-woven shopping bags

58

Innovative design and simulation of clothing products for children with atypical changes in conformation and posture

Comparison of mechanical properties, hand and tailorability of wool blended fabrics for outerwear clothing

\section{Scientific reviewers for the papers published in this number:}

Dragana Grujić - PhD., Associate professor, University of Banja Luka, Faculty of Technology, Bosnia and Herzegovina Svjetlana Janjić, PhD., Associate professor, University of Banja Luka, Faculty of Technology, Bosnia and Herzegovina Lilioara Surdu, PhD. Eng., The National Research \& Development Institute for Textiles and Leather, Bucharest, Romania Ursache Mariana, PhD. Prof. Eng., "Gheorghe Asachi" Technical University of lasi, Faculty of Textile, Leather and Industrial Management, lasi, Romania

Antoanela Curteza, PhD. Prof. Eng., "Gheorghe Asachi” Technical University of lasi, Faculty of Textile, Leather and Industrial Management, lasi, Romania

Savvas G. Vassiliadis, Prof., Technological Education Institute of Piraeus, Department of Electronics, Athens, Greece

Abdul Jabbar, Prof., Department of Material Engineering, Technical University of Liberec, Liberec, Czech Republic Claudia Niculescu, Eng, Senior Researcher $3^{\text {rd }}$ degree, The National Research \& Development Institute for Textiles and Leather, Bucharest, Romania

\section{EDITORIAL STAFF}

Editor-in-chief: Dr. eng. Emilia Visileanu Graphic designer: Florin Prisecaru e-mail: industriatextila@certex.ro

Journal edited in colaboration with Editura AGIR, 118 Calea Victoriei, sector 1, Bucharest, tel./fax: 021-316.89.92; 021-316.89.93; e-mail: editura@agir.ro,www.edituraagir.ro 


\section{Determinarea drapajului țesăturilor din bumbac}

Drapajul țesăturii poate fi definit ca un fenomen de formare a cutelor atunci când țesătura este sub presiunea masei proprii, dar fără influența forțelor externe. Drapajul materialului are o influență directă asupra aspectului și funcționalității articolului de îmbrăcăminte. Descoperirile recente în acest domeniu indică faptul că cercetătorii au definit fenomenul de drapaj pe baza caracteristicilor mecanice ale textilelor. Această lucrare prezintă metoda care are drept scop determinarea parametrilor de drapaj, acesta fiind definit în funcție de structura și parametrii de construcție ai țesăturilor. Caracteristicile de drapaj sunt testate pe instrumentul de măsurare a drapajului. Coeficientul de drapaj a fost determinat prin metoda "cut weight". Este utilizată o varietate de materii prime și țesături finite pentru îmbrăcăminte, pentru a explica modul în care modificările caracteristicilor structurale și de construcție afectează drapajul țesăturii. Pe baza rezultatelor, este prezentată ecuația care poate fi utilizată pentru a determina drapajul țesăturii. Rezultatele obținute furnizează parametrii de drapaj în funcție de parametrii structurali și de construcția materialelor țesute.

Cuvinte-cheie: drapaj, țesătură, desimea firelor, densitate lineară, cute, masa superficială

\section{Cotton type fabric drape prediction}

Fabric drape can be defined as a phenomenon of crease-forming when the fabric is put under pressure of its own mass, but without the influence of external forces. The drape ability of material has a direct influence on appearance and functionality of the garment. Recent findings in this field indicate that researchers have mostly been defining the phenomenon of draping on the basis of the mechanical characteristics of textiles. This paper presents the method that aims to to predict the draping parameters, where drape is defined in dependence of structure and construction parameters of woven fabric. Drape characteristics are tested on drape meter. Drape coefficient was determined by "cut weight" method. Variety of raw and finished fabrics for apparel are used, in order to explain how the changes of structural and constructional characteristics affect the woven fabric draping. Based on the results it is presented the equation that can be used to predict draping of woven fabric. The obtained results are aimed to provide drape parameters depending on the parameters of the structure and the construction of woven materials.

Keywords: draping, fabric, thread density, linear density, crimp, surface mass

\section{INTRODUCTION}

The ability of material to drape is a feature that defines the qualitative characteristics of the fabric and design of apparel products. Contemporary fashion trends and modern technologies impose more requirements to the textile industry. New and functional textile materials, modern methods of making apparel, competition in the world of fashion and clothing are factors that impose the fashion industry constant change and adaptation to the markets requirements. Fabric drape can be defined as a phenomenon of crease-forming when the fabric is put under pressure of its own mass, but without the influence of external forces. The drape ability of material has a direct influence on appearance and functionality of the garment [1].

As a numerical indicator of drape ability of fabrics is used drape coefficient (DC), which can be defined as a ratio of ring area of fabric sample before draping and projected area of draped part of the fabric, expressed as a percentage [2]. In addition to drape coefficient for description of the fabric drape there are used: minimum and maximum amplitude (minimum and maximum distance between the center of the circle and draped part of the sample), the number of folds, distribution of folds, drape profile circularity and others [3].

There are two basic approaches for evaluating and testing the drape in the textile and apparel industry. In other words, draping can be classified into two categories: two-dimensional and three-dimensional draping. The two-dimensional draping means that the fabric folds under the influence of its own mass in one plane. In the three-dimensional fabric drape fabric deforms under the influence of its own mass, in more than one plane. The study of two-dimensional drape set Pierce, establishes "cantilever method" [4]. The study of three-dimensional drape starts with a Chu (1950) when he set up measuring methods for fabric drape using F.R.L drape meter. Later, the three-dimensional draping studied a number of authors and finally Cusick (1968) reviewed experimental methods using parallel light source that reflects the shadow of draped part of fabric with circular shape on a piece of paper. He has also developed a new method of calculating the drape coefficient measuring the mass of paper drape, "cut weight" method [5]. 
Nowadays, for calculating the drape coefficient by Cusicks method usually applies the British standard BS 5058, according to which the fabric sample diameter of $30 \mathrm{~cm}$ is placed on a pedestal of $18 \mathrm{~cm}$ in diameter. In recent years, the profile of draped sample is recorded with a digital camera, and drape coefficient and other drape parameters are determined using a variety of computer software $[6,7]$.

Fabric drape referred to in the literature as a complex term because it depends on many parameters: the structural and mechanical characteristics of the fabric, as well as various external influences from the environment. The shape of draped fabric changing over time due to the influence of gravity on the sample. Changes in the draping of the fabric under the influence of time shows that drape coefficient increases exponentially with time. It should be taken into account that any time when material is draped it occupies a different configuration. The reasons for this unpredictable formation when fabric drape lies in mentioned parameters of fabrics including their inhomogeneous structure, the shape of the object on which the fabric is draped, sample size, etc. [8].

Research in this area mainly dealt with the analysis of the correlation between mechanical properties and fabric drape. It was found that the bending stiffness of the fabric has a significant influence on drape [9].

However, it was found that fabric drape depends on the structural characteristics of the fabric, such as: types of yarn, fiber composition, applied weave, fabric density etc. [10]. The density of warp and weft threads, linear density of warp and weft threads and crimp of the warp and weft threads in fabric are structure parameters that can be changed in the process of weaving on a weaving machine, in order to achieve optimal characteristics of woven fabric [11].

This paper analyzes the draping of fabric with different structural characteristics, in order to develop a method that can be used to predict drape woven fabric.

\section{EXPERIMENTAL WORK}

\section{Materials and Method}

The aim of this research is to acquire knowledge about the connection between the mass of woven fabric and the drape coefficient. Therefore, there were formed 18 different fabrics on modern weaving machines, which characteristics are shown in tables 1 and 2. Fabrics 1 to 7 (table 1) are formed on the same basis in plain weave and differ in density of

Table 1

\begin{tabular}{|c|c|c|c|c|c|c|c|c|}
\hline \multicolumn{9}{|c|}{ CHARACTERISTICS OF RAW FABRICS IN PLAIN WEAVE } \\
\hline \multirow{2}{*}{$\begin{array}{l}\frac{0}{0} \\
\frac{0}{E} \\
\infty \\
\infty\end{array}$} & \multicolumn{2}{|c|}{ Linear density (tex) } & \multicolumn{2}{|c|}{ Thread density $\left(\mathrm{cm}^{-1}\right)$} & \multicolumn{2}{|c|}{ Crimp coefficient } & \multirow{2}{*}{$\begin{array}{c}\begin{array}{c}\text { Surface } \\
\text { mass } \\
\left(\mathrm{g} / \mathrm{m}^{2}\right)\end{array}\end{array}$} & \multirow{2}{*}{$\begin{array}{c}\text { Drape } \\
\text { coefficient } \\
(\%)\end{array}$} \\
\hline & $\begin{array}{c}\text { Warp } \\
T_{t, \text { wa }}\end{array}$ & $\begin{array}{l}\text { Weft } \\
T_{t, \text { we }}\end{array}$ & $\begin{array}{c}\text { Warp } \\
d_{w a}\end{array}$ & $\begin{array}{c}\text { Weft } \\
d_{w e}\end{array}$ & $\begin{array}{c}\text { Warp } \\
k_{\text {uwa }}\end{array}$ & $\begin{array}{l}\text { Weft } \\
k_{\text {uwe }}\end{array}$ & & \\
\hline 1 & 18,52 & 23,5 & 37 & 18,5 & 1,184 & 1,0634 & 127,32 & 48,06 \\
\hline 2 & 18,52 & 23,5 & 36,5 & 20,5 & 1,1742 & 1,042 & 124,57 & 52,42 \\
\hline 3 & 18,52 & 23,5 & 36,5 & 21 & 1,1544 & 1,068 & 130,74 & 51,31 \\
\hline 4 & 18,52 & 23,5 & 36,5 & 23 & 1,0574 & 1,1881 & 135,62 & 57,19 \\
\hline 5 & 18,52 & 23,5 & 37 & 28 & 1,206 & 1,162 & 159,01 & 63,53 \\
\hline 6 & 18,52 & 23,5 & 37 & 29 & 1,1821 & 1,164 & 160,57 & 67,59 \\
\hline 7 & 18,52 & 23,5 & 37,5 & 32 & 1,192 & 1,0633 & 162,65 & 71,87 \\
\hline
\end{tabular}

Table 2

\begin{tabular}{|c|c|c|c|c|c|c|c|c|}
\hline \multicolumn{9}{|c|}{ CHARACTERISTICS OF RAW FABRICS IN FIVE-THREAD SATIN WEAVE } \\
\hline \multirow{2}{*}{ 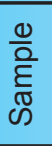 } & \multicolumn{2}{|c|}{ Linear density (tex) } & \multicolumn{2}{|c|}{ Thread density $\left(\mathrm{cm}^{-1}\right)$} & \multicolumn{2}{|c|}{ Crimp coefficient } & \multirow{2}{*}{$\begin{array}{c}\text { Surface } \\
\text { mass } \\
\left(\mathrm{g} / \mathrm{m}^{2}\right)\end{array}$} & \multirow{2}{*}{$\begin{array}{c}\text { Drape } \\
\text { coefficient } \\
(\%)\end{array}$} \\
\hline & $\begin{array}{c}\text { Warp } \\
T_{t, \text { wa }}\end{array}$ & $\begin{array}{l}\text { Weft } \\
T_{t, w e}\end{array}$ & $\begin{array}{c}\text { Warp } \\
d_{\text {wa }}\end{array}$ & $\begin{array}{c}\text { Weft } \\
d_{w e}\end{array}$ & $\begin{array}{c}\text { Warp } \\
k_{\text {uwa }}\end{array}$ & $\begin{array}{l}\text { Weft } \\
k_{\text {uwe }}\end{array}$ & & \\
\hline 8 & $13,54 \times 2$ & 19,55 & 43 & 36 & 1,1172 & 1,0931 & 185,65 & 43,00 \\
\hline 9 & $13,54 \times 2$ & $25,04 \times 2$ & 42 & 32 & 1,206 & 1,0415 & 303,95 & 69,70 \\
\hline 10 & $13,54 \times 2$ & $11,13 \times 2$ & 43 & 31 & 1,1164 & 1,0776 & 204,36 & 44,33 \\
\hline 11 & $13,54 \times 2$ & $14,62 \times 2$ & 41 & 33 & 1,1575 & 1,0368 & 228,56 & 49,62 \\
\hline 12 & $13,54 \times 2$ & $14,34 \times 2$ & 41 & 34 & 1,1742 & 1,03 & 231,21 & 54,19 \\
\hline 13 & $13,54 \times 2$ & 24,37 & 44 & 35 & 1,1152 & 1,0945 & 226,23 & 48,15 \\
\hline 14 & $13,54 \times 2$ & 35,85 & 43 & 34 & 1,176 & 1,06 & 266,14 & 59,77 \\
\hline 15 & $13,54 \times 2$ & 29,86 & 42 & 31 & 1,1604 & 1,052 & 229,36 & 57,81 \\
\hline 16 & $13,54 \times 2$ & $20,75 \times 2$ & 43 & 33 & 1,188 & 1,04 & 280,76 & 67,51 \\
\hline 17 & $13,54 \times 2$ & 34,73 & 40 & 33 & 1,154 & 1,0435 & 244,60 & 55,27 \\
\hline 18 & $13,54 \times 2$ & $17,28 \times 2$ & 46 & 33 & 1,157 & 1,086 & 268,00 & 53,78 \\
\hline
\end{tabular}




\begin{tabular}{|c|c|c|c|c|c|c|c|c|c|}
\hline \multicolumn{10}{|c|}{ TECHNICAL CHARACTERISTICS OF FINISHED FABRICS } \\
\hline \multirow{2}{*}{ 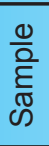 } & \multicolumn{2}{|c|}{ Linear density (tex) } & \multicolumn{2}{|c|}{ Thread density $\left(\mathrm{cm}^{-1}\right)$} & \multicolumn{2}{|c|}{ Crimp coefficient } & \multirow{2}{*}{$\begin{array}{c}\text { Surface } \\
\text { mass } \\
\left(\mathrm{g} / \mathrm{m}^{2}\right)\end{array}$} & \multirow{2}{*}{$\begin{array}{c}\text { Drape } \\
\text { coefficient } \\
(\%)\end{array}$} & \multirow{2}{*}{ Fabric weave } \\
\hline & $\begin{array}{c}\text { Warp } \\
T_{t, w a}\end{array}$ & $\begin{array}{l}\text { Weft } \\
T_{t, w e}\end{array}$ & $\begin{array}{c}\text { Warp } \\
d_{\text {wa }}\end{array}$ & $\begin{array}{c}\text { Weft } \\
d_{w e}\end{array}$ & $\begin{array}{c}\text { Warp } \\
k_{\text {uwa }}\end{array}$ & $\begin{array}{l}\text { Weft } \\
k_{\text {uwe }}\end{array}$ & & & \\
\hline 1 & 30 & 30 & 27 & 18 & 1,0417 & 1,2116 & 159,8 & 68,7 & Plain \\
\hline 2 & 50 & 48 & 22 & 22 & 1,086 & 1,0618 & 231,59 & 87,5 & Plain \\
\hline 3 & 20 & 25 & 40 & 25 & 1,0619 & 1,12 & 154,95 & 68,7 & Plain \\
\hline 4 & 30 & 34 & 30 & 22 & 1,0583 & 1,225 & 186,88 & 73,3 & Plain \\
\hline 5 & 30 & 30 & 28 & 22 & 1,0617 & 1,1323 & 163,91 & 79,2 & Plain \\
\hline 6 & 30 & 30 & 24 & 24 & 1,095 & 1,18 & 156,6 & 72,0 & Plain \\
\hline 7 & $17 \times 2$ & $17 \times 2$ & 37 & 20 & 1,0985 & 1,0785 & 211,53 & 75,6 & Plain \\
\hline 8 & $7,6 \times 2$ & 17 & 43 & 28 & 1,1563 & 1,0692 & 126,47 & 57,2 & Plain \\
\hline 9 & 15 & 16 & 47 & 29 & 1,065 & 1,163 & 129,1 & 56,0 & Plain \\
\hline 10 & 10,5 & 14 & 56 & 33 & 1,1 & 1,1 & 115,5 & 62,3 & Plain \\
\hline 11 & 14 & 14 & 44 & 37 & 1,1138 & 1,1107 & 126,14 & 59,9 & Plain \\
\hline 12 & 10 & 11,5 & 34 & 23 & 1,1256 & 1,1256 & 68,04 & 43,0 & Plain \\
\hline 13 & 14 & 13 & 44 & 35 & 1,0784 & 1,1153 & 117,18 & 61,2 & Plain \\
\hline 14 & 10 & 10 & 70 & 35 & 1,123 & 1,0307 & 114,68 & 60,2 & Plain \\
\hline 15 & 14 & 14 & 53 & 40 & 1,0984 & 1,1092 & 143,62 & 69,3 & Plain \\
\hline 16 & 14 & 14 & 56 & 37 & 1,103 & 1,0974 & 143,32 & 67,3 & Plain \\
\hline 17 & 20 & 20 & 45 & 23 & 1,0876 & 1,0538 & 146,36 & 75,3 & Plain \\
\hline 18 & 14 & 14 & 48 & 28 & 1,103 & 1,0519 & 115,29 & 65,5 & Plain \\
\hline 19 & 14 & 14 & 63 & 26 & 1,0876 & 1,0903 & 135,61 & 65,1 & Plain \\
\hline 20 & 13 & 14 & 53 & 28 & 1,0876 & 1,1153 & 118,66 & 63,2 & Plain \\
\hline 21 & 10 & 10,5 & 33 & 31 & 1,12 & 1,1243 & 73,33 & 48,3 & Plain \\
\hline 22 & 24 & 28 & 49 & 26 & 1,1036 & 1,18 & 215,69 & 80,4 & Twill 2/1 \\
\hline 23 & 25 & 25 & 43 & 25 & 1,0615 & 1,1153 & 183,82 & 73,7 & Twill 2/1 \\
\hline 24 & 30 & 30 & 40 & 27 & 1,0692 & 1,1345 & 220,2 & 74,7 & Twill 2/1 \\
\hline 25 & 30 & 28 & 45 & 21 & 1,0923 & 1,0723 & 210,51 & 71,4 & Twill 2/1 \\
\hline 26 & 25 & 30 & 43 & 23 & 1,1 & 1,0794 & 192,73 & 64,3 & Twill 2/1 \\
\hline 27 & 17 & 20 & 56 & 27 & 1,0667 & 1,1 & 160,95 & 63,9 & Twill 2/1 \\
\hline 28 & 30 & 30 & 48 & 23 & 1,0862 & 1,0699 & 230,24 & 82,0 & Twill 3/1 \\
\hline 29 & 30 & 42 & 49 & 24 & 1,095 & 1,0533 & 267,14 & 87,6 & Twill 3/1 \\
\hline 30 & 38 & 38 & 22 & 22 & 1,023 & 1,1815 & 184,3 & 79,0 & Twill 3/1 \\
\hline 31 & 33 & 50 & 42 & 19 & 1,1095 & 1,083 & 256,66 & 77,6 & Twill 3/1 \\
\hline 32 & 30 & 50 & 44 & 21 & 1,1046 & 1,1108 & 262,44 & 82,0 & Twill 3/1 \\
\hline 33 & 28 & 28 & 48 & 22 & 1,0517 & 1,0462 & 205,8 & 72,9 & Twill 3/1 \\
\hline 34 & $30 \times 2$ & 64 & 27 & 16 & 1,0483 & 1,12 & 284,51 & 85,6 & Twill 2/2 \\
\hline 35 & $17 \times 2$ & $17 \times 2$ & 37 & 22 & 1,0367 & 1,1667 & 194,53 & 70,2 & Panama $2 / 2$ \\
\hline 36 & $10 \times 2$ & $17 \times 2$ & 46 & 25 & 1,05 & 1,0916 & 189,39 & 66,2 & $\begin{array}{l}\text { Five-thread } \\
\text { satin }\end{array}$ \\
\hline 37 & 25 & 25 & 39 & 28 & 1,0583 & 1,14 & 183 & 63,4 & $\begin{array}{c}\text { Five-thread } \\
\text { satin }\end{array}$ \\
\hline 38 & 7,2 & 6 & 78 & 37 & 1,0492 & 1,0661 & 82,59 & 46,1 & $\begin{array}{l}\text { Five-thread } \\
\text { satin }\end{array}$ \\
\hline
\end{tabular}

weft threads. Fabrics 8 to 18 (table 2) are formed on the same basis in five-wire satin weave but with different linear density of weft threads. Based on the obtained results the goal is to acquire knowledge about the influence of density of warp and weft threads (in other approximately equal parameters) on drape coefficient. The results also aim to show the impact of different values of linear densities of the weft threads in woven fabric on drape.
Table 3 shows the characteristics of 38 finished cotton fabrics intended for garments.

The characteristics of the fabric were determined using the methods described by following standards: Surface mass of the fabric is determined in accordance with standard SRPS F.S2.016 i BS EN 12127 $[12,13]$.

Linear density of yarn is determined according to standard SRPS ISO 7211-5 i DIN 53830-3 [14,15]. 


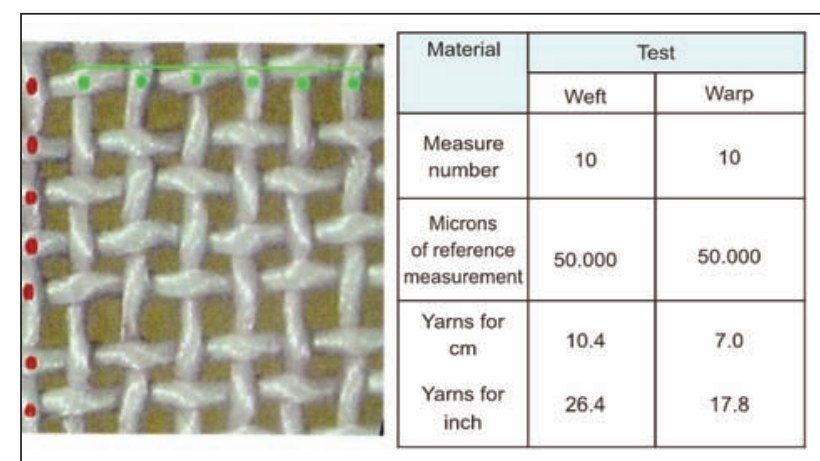

Fig. 1. Determination of density of warp and weft threads with the computer-controlled (stereo) microscope Video Analyser 2000

Determination of warp and weft threads crimp is determined in accordance with standard ISO 7211 (1 do 6) [16-21].

Determination of density of warp and weft threads (gwa i gwe) was carried out with the computer-controlled (stereo) microscope Video Analyser 2000, using software Mesdan Video Analyser (figure 1).

Determination of drape parameters is carried out on a standardized test device drape tester James $\mathrm{H}$ Heal \& Co, model 665, according to British standard BS 5058 (figure 2). This experimental method means that circular fabric sample $30 \mathrm{~cm}$ in diameter, hangs on a circular disk $18 \mathrm{~cm}$ in diameter.

The drape coefficients were determined by "cut weigh" method, which means that the projected image of the draped sample is traced on the ring-shaped piece of paper which is placed on the upper panel of the device (figure 3 ). On the analytical scale was measured paper mass $m_{1}$, then cut the contour of traced drape profile of the sample and measure its mass $m_{2}$. From the relation berween these two masses, drape coefficient is obtained.

$$
D C=\frac{m_{2}}{m_{1}} \cdot 100 \quad[\%]
$$

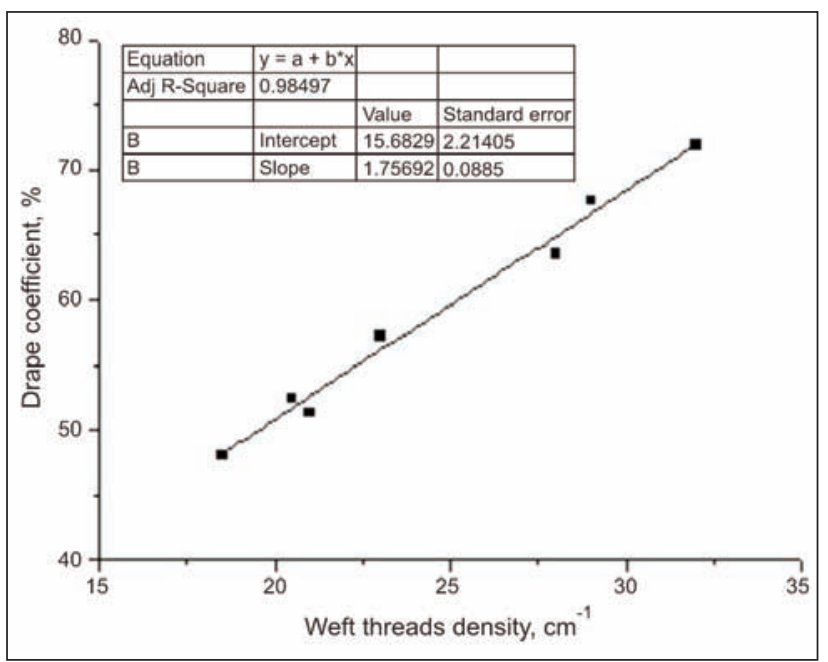

Fig. 4. Drape coefficient - weft threads density of raw fabrics in plain weave

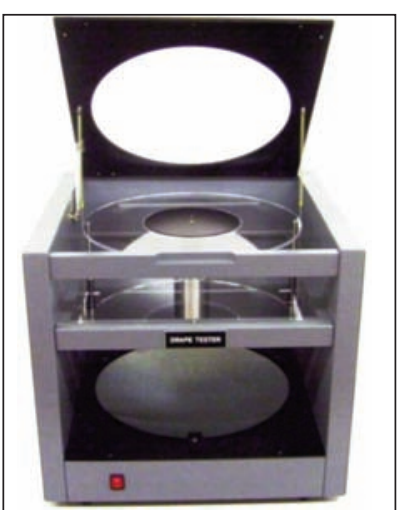

Fig. 2. Drape tester 665

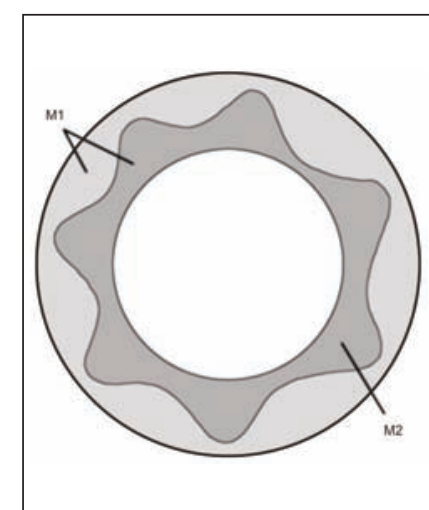

Fig. 3. Method "cut\&weigh"
From equation (1) it can be concluded that stiffer fabrics have higher drape coefficient values, while softer fabrics, which are easier to shape, have lower drape coefficient values.

For all samples drape coefficient was determined. The results are shown in tables 1 to 3 .

\section{RESULTS}

By analyzing the results shown in tables 1 and 2 it can be concluded that fabrics with higher surface mass have a lower propensity for draping, or may be more difficult to form in the process of further processing.

Figure 4 shows the correlation between the density of weft threads in fabric and drape coefficient of raw fabrics in plain weave, which differ in density of weft threads. Figure 5 shows the relation between surface mass and drape coefficient of these fabrics (table 1). The results show that the change in density of weft threads has an impact on woven fabrics draping ability (figure 4). The correlation coefficient between these parameters $(r=0.98497)$ confirms that statement.

Figure 6 shows the connection between the linear density of weft threads and drape coefficient of raw fabrics in five-thread satin weave. Figure 7 shows the

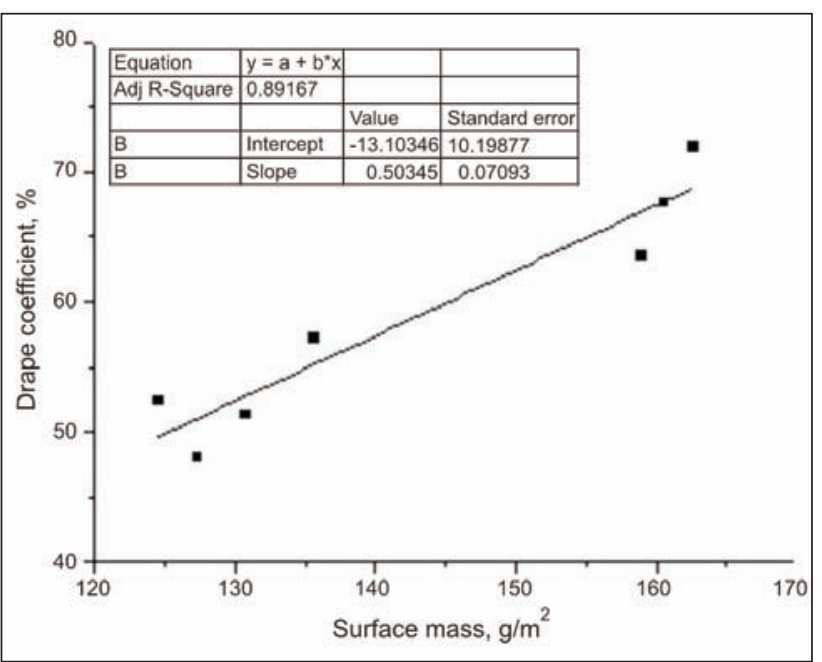

Fig. 5. Drape coefficient - surface mass of raw fabrics in plain weave 


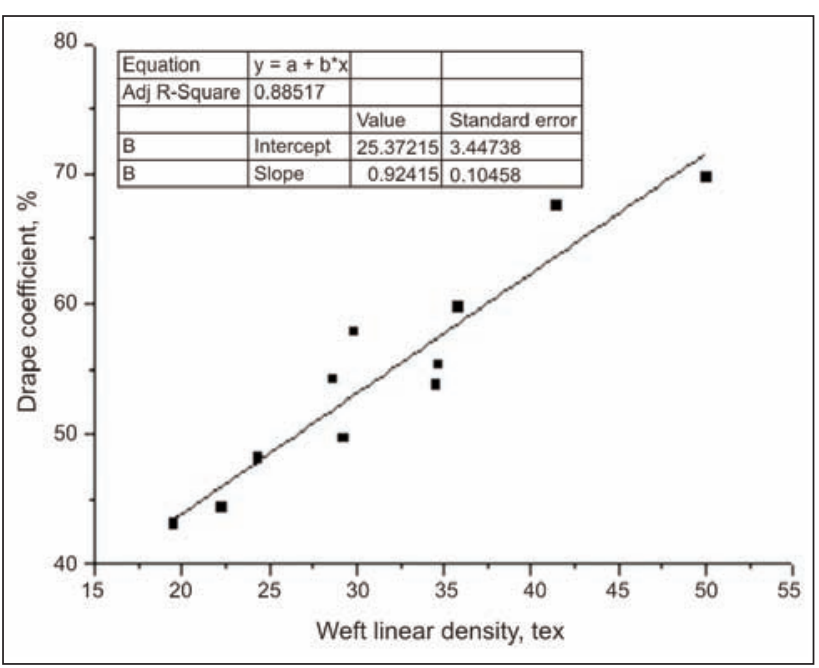

Fig. 6. Drape coefficient - linear density of weft threads of raw fabrics in satin weave

correlation between drape coefficient and surface mass of these fabrics (table 2).

The value of the correlation coefficient $(r=0.88517)$ indicates the correct connection of the given parameters.

Application of weft threads with larger linear density, at about the same other parameters of fabric structure, leading to an increase in stiffness of the fabric, thus fabrics have a lower propensity to drape.

Since the draping is defined as the phenomenon of formation of folds when the fabric is loaded with its own mass, without the influence of external forces, it is expected that the fabrics with higher mass have greater ability to drape. However, the measurement results showed that the fabrics with higher surface mass values have a lower propensity to drape (greater drape coefficient values). This can be explained because fabrics greater surface mass have greater stiffness and therefore less ability to draping.

In order to develop methods for predicting drape of woven fabric, there were also discussed the results of the finished commercial fabrics for garments (table 3). The parameters taken into consideration are linear density of warp and weft threads, density and warp and weft threads and crimp of warp and weft threads. These are parameters which may be influenced and simultaneously they define surface mass of woven fabric.

Respectively, the surface mass of the fabric can be defined by the equation:

$$
\begin{array}{r}
m=0,1 \cdot\left(T_{t, w a} \cdot d_{w a} \cdot k_{u w a}+T_{t, w e} \cdot d_{w e} \cdot k_{u w e}\right) \\
{\left[g^{-2}\right]}
\end{array}
$$

Where is:

$m$ - mass per square meter of fabric $\left(\mathrm{gm}^{-2}\right)$;

$T_{t, w a}-$ warp linear density (tex);

$T_{t, w e}$ - weft linear density (tex);

$d_{w a}$, warp thread density $\left(\mathrm{cm}^{-1}\right)$;

$d_{w e}-$ weft linear density $\left(\mathrm{cm}^{-1}\right)$;

$k_{\text {uwa }}$ - warp crimp coefficient;

$k_{\text {uwe }}-$ weft crimp coefficient.

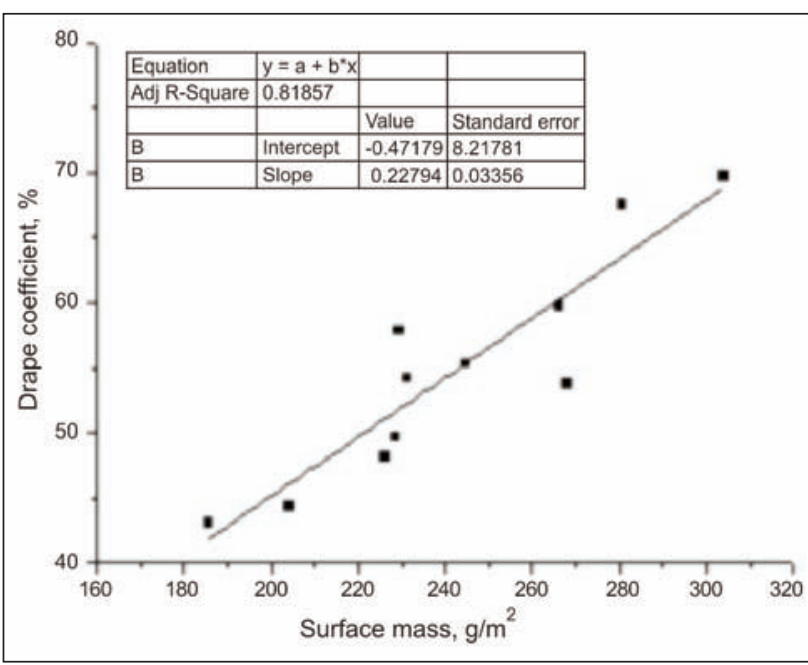

Fig. 7. Drape coefficient - surface mass of raw fabrics in satin weave

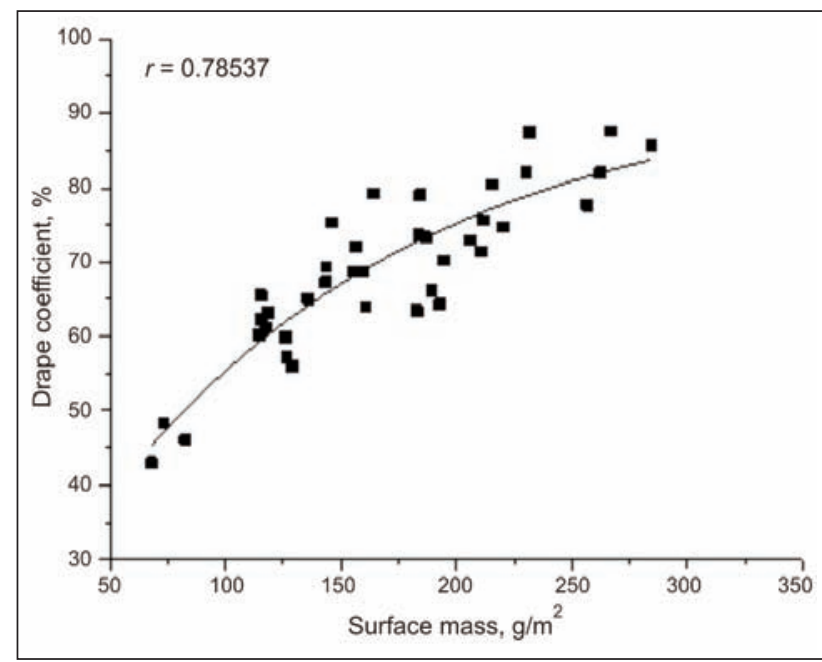

Fig. 8. Drape coefficient - surface mass of finished fabrics

Figure 8 shows the correlation between surface mass of finished fabrics and drape coefficient.

Dependence of drape coefficient and surface mass of finished fabrics can be represented by the equation:

$$
D C=93,82-79,42 \cdot \exp (-m / 137,85) \quad[\%]
$$

Respectively, by introducing the parameters of the equation 2 into equation 3 :

$$
\begin{aligned}
& D C=93,82-79,42 \cdot \\
& \cdot \exp \left(-\frac{T_{t, w a} \cdot d_{w a} \cdot k_{u w a}+T_{t, w e} \cdot d_{w e} \cdot k_{u w e}}{1,3785 \cdot 10^{3}}\right)[\%]
\end{aligned}
$$

The proposed equation can be used to predict fabric drape coefficient approximately. Since the linear densities of applied yarn, thread densities and crimp of warp and weft threads are parameters that can influenced in the process of fabric formation, thus providing the ability to use them for prediction of fabric drape. The parameters of the structure of the fabric can be used to determine the ability of fabrics to drape, and thus to predict the aesthetic appearance of the finished garment. 


\section{CONCLUSIONS}

Prediction of behavior of woven fabric during the production of garments and during exploitation as well, has significant economic benefits in terms of saving time and materials, which is one of the factors for increasing the competitiveness in the market. Therefore it is very important to study all the parameters and properties of textile materials affecting the drape ability.

The research results show that the change in density of weft threads in fabric may change the drape properties of fabric. By selecting the structural parameters can influenced fabric drape ability, according to the purpose and properties that are required by the garment.

In addition, there was observed good correlation between the drape coefficient, density of weft threads, linear density of weft threads and surface mass of fabric.

Based on the results there are proposed the equations that can be used to predict drape of woven fabrics for garment industry.

\section{BIBLIOGRAPHY}

[1] Frydrych I., Dziworska G., Cieslinska A., Mechanical fabric properties influencing drape and handle, In: International Journal of Clothing Science and Technology, 2000, vol. 12, no. 3, pp. 171-183

[2] Žunič Lojen D., Jevšnik S., Some Aspects of Fabric Drape, In: Fibres \& Textiles in Eastern Europe, 2007, vol. 15, no. 4, pp. 39-45

[3] Jevšnik S., Geršak J., Modelling the Fused Panel for a Numerical Simulation of Drape, In: Fibres \& Textiles in Eastern Europe, 2004, vol. 12, no. 1, pp. 47-52

[4] Žunič Lojen D., Jevšnik S., Some Aspects of Fabric Drape, In: Fibres \& Textiles in Eastern Europe, 2007, vol. 15, no. 4 , pp. 39-55

[5] Cusick G. E., A study of Fabric Drape, In: Faculty of Technology, University of Manchester, 1962.

[6] Robson D., Long C. C., Drape Analysis using Imaging Techniques, In: Clothing and Textiles Research Journal 2000 , vol. 18 , no. 1 , pp. 1-8

[7] Kenkare N., May-Plumlee T., Fabric Drape Measurement: A Modified Method Using Digital Image Processing, In: Journal of Textile and Apparel, 2005, vol. 4, no. 3, pp. 1-8

[8] Szabo L., Halasz M., Examination of dependence of drape coefficient on the samples size, In: Tekstil, 2008 , vol. 57, no. 9, pp. 439-447

[9] Nofitoska M., Demboski G., Carvalho M. A. F., Effect of fabric structure variation on garment aesthetic properties, In: Tekstil ve Konfeksiyon, 2012, vol. 22, no. 2, pp. 132-136

[10] Šarac T., Stepanović J., Demboski G., Petrović V., Fabric draping and cotton fabric structure relation analysis, In: Advanced Technologies, 2015, vol. 4, no. 1, pp. 84-88

[11] Stepanović J., Ćirković N., Radivojevic D., Reljić M., Defining the warp length required for weaving process, In: Industria textila, 2012, vol. 63, no. 5, pp. 227-231.

[12] SRPS F.S2.016 Tekstil - Metražna roba - Određivanje mase po jedinici dužine i jedinici površine, 1986

[13] BS EN 12127 Textiles. Fabrics. Determination of mass per unit area using small samples, 1998

[14] SRPS ISO 7211-5 Tekstil - Tkanine - Konstrukcija - Metode analiza - Deo 5: Određivanje linearne gustine pređe iz tkanine, 2005

[15] DIN 53830-3Prüfung von Textilien - Bestimmung der Feinheit von Garnen und Zwirnen - Einfache Garne und Zwirne, texturierte Garne - Abschnittverfahren,1981

[16] ISO 7211-1 Textiles - Woven fabrics - Construction - Methods of analysis - Part 1: Methods for the presentation of a weave diagram and plans for drafting, denting and lifting, 1984

[17] ISO 7211-2 Textiles - Woven fabrics - Construction - Methods of analysis - Part 2: Determination of number of threads per unit length, 1984

[18] ISO 7211-3 Textiles - Woven fabrics - Construction - Methods of analysis - Part 3: Determination of crimp of yarn in fabric, 1984

[19] ISO 7211-4 Textiles - Woven fabrics - Construction - Methods of analysis - Part 4: Determination of twist in yarn removed from fabric, 1984

[20] ISO 7211-5 Textiles - Woven fabrics - Construction - Methods of analysis - Part 5: Determination of linear density of yarn removed from fabric, 1984

[21] ISO 7211-6 Textiles - Woven fabrics - Construction - Methods of analysis - Part 6: Determination of the mass of warp and weft per unit area of fabric, 1984

\section{Authors:}

\section{TATJANA ŠARAC 1 JOVAN STEPANOVIĆ 1 VASIJLIJE PETROVIĆ2 GORAN DEMBOSKI ${ }^{3}$}

${ }^{1}$ Faculty of Technology, University of Niš/Bulevar oslobođenja 124, 16000 Leskovac, Serbia

${ }^{2}$ Technical faculty, Zrenjanin, University of Novi Sad/Đure Đakovića 66, 23000 Zrenjani, Serbia
${ }^{3}$ Faculty of Technology and Metallurgy, Skoplje, University of Skoplje/Nikola Tesla 16, 1000 Skopje, Macedonia

e-mail: tangerine_art@hotmail.com, jovan@tf.ni.ac.rs, vip@eunet.yu,goran@tmf.ukim.edu.mk

Corresponding author:

Tatjana Šarac

e-mail: tangerine_art@hotmail.com 


\section{The study of strain proprieties of woolen yarns mixed with elastomer, bleached and coloured}

\section{REZUMAT - ABSTRACT}

\section{Studiul proprietăților mecanice ale firele de lână în amestec cu elastomer, albite şi colorate}

Firele au caracteristici mecanice care le permit realizarea de structuri țesute, tricotate etc. pentru produse textile. Rezistența la întindere este una dintre caracteristicile de bază ale firului, deoarece influențează modul de comportare în procesele de prelucrare (pregătirea pentru țesere, țesere, tricotare), determinând parametrii tehnologici de reglare ai utilajelor, precum și productivitatea lor. De asemenea, rezistența firului la întindere constituie o caracteristică calitativă, deoarece de valoarea ei depinde calitatea acestuia și cea a produsului. Din aceste motive, caracteristica menționată este prevăzută în norme interne și standarde care cuprind valoarea minimă admisibilă, în funcție de materia primă, tehnologia de obținere și destinație.

În această lucrare s-au analizat, cu ajutorul aparatului USTER® TENSOJET 4, fire din $75 \%$ lână și 25\% elastomer, de finețe $\mathrm{Nm}$ 34/1 și torsiunea de 470 tors $/ \mathrm{m}$. Studiul comparativ din punctul de vedere al rezistenței la rupere al acestor fire s-a realizat pentru două loturi de fire, primul lot fiind fire albite, iar al doilea lot, fire vopsite, destinate tricotării. Din punct de vedere practic, rezistența se apreciază prin valoarea medie și coeficientul de variație.

Cuvinte-cheie: fibre, fire, rezistență la tracțiune, alungire la rupere, USTER® TENSOJET 4.

\section{The study of strain proprieties of woolen yarns mixed with elastomer, bleached and coloured}

Textile yarns have mechanical properties that enable their transformation using woven, knitted structures or other procedures into textile products.

Tensile strength is one of the basic features of the yarn because it influences the behaviour of yarns in processing (preparation for weaving, weaving, knitting) determining the technological parameters of equipment adjustment, and their productivity. Also, the breaking strength of yarns is a qualitative characteristic because its value depends on its quality and the product. For these reasons the characteristic mentioned above is established by internal norms and STAS by the minimum permissible value, depending on the feedstock, production technology and destination.

In this paper there were analysed the woolen yarns $75 \%$ mixed with elastomer $25 \%$, fineness of $34 / 1 \mathrm{Nm}$ and torque of 470 twists/m using the device USTER® TENSOJET 4. The comparative study in terms of breaking strength of these yarns was conducted for two groups of yarns, the first batch being bleached yarns and the second batch, colour yarns (dyed) for knitting. From a practical standpoint, the resistance is evaluated by the average value and the coefficient of variation.

Keywords: fibers, yarns, breaking strength, breaking elongation, USTER® TENSOJET 4.

\section{INTRODUCTION}

Wool yarns, as all yarns are multicellular fibers which from a morphologic point of view consist of three main structural parts or three cell layers, the distinction between them: cuticular layer, cortical layer which is the part that forms the fiber wool (approx. $85 \%$ of the fiber volume), and medullary layer is located inside the fiber and only in thick wool fiber [1].

Strain properties of the wool fiber are determined by the morphological structure of the fiber, of the wool quality, testing conditions, etc. The breaking strength of the fiber depends on its diameter from a physical and temperature point of view and in terms of the heat treatment to which it is subjected. The yarns studied are woolen in combination with elastomer thus is improves the elasticity and resistence of the yarn as a mix, compared to $100 \%$ wool [2].

This improvement in the yarns resistance is realized as being a transfer characteristic of the constituent fibers resistance and depends on the following factors: the nature of the raw material, yarn fineness, yarn twisting (depending on destination) characteristics of the component fiber (strength, fineness, length, surface status) yarns structure (twisted) mechanical, chemical, thermal treatments, etc.

Resistance is a characteristic that influences the degree of yarns processing and depending on its value the quality of the yarn is established [3].

\section{MODELING METHOD}

The wool as organic material, belongs to a class of proteins called keratin. Within proteins, keratins are characterized by great physical, mechanical, chemical and biochemical strength.

Wool has a great range of properties such as geometrical characteristics of wool yarns (length, thickness, undulation and elasticity) and strain properties (breaking strength, elongation at break, toughness, breaking mechanical operation) [1]. 
In terms of the elasticity the wool is ranked second after polyamide fibers. In the case of wool, the elasticity confers softness and resistance to wear of articles during use.

Strain properties of wool are determined by the morphological structure of the fiber, the quality of wool, testing conditions.

The breaking strength of wool yarn represents its property to withstand certain outdoor applications. It is expressed most frequently in $\mathrm{CN}$ and depends on its diameter from the physical and temperature point of view of the thermal treatment to which it is subjected (bleaching, dyeing, etc.) [4].

Toughness represents the ratio between the breaking force and length density expressed in tex or denier $\left(T_{\text {tex }}\right.$ or $\left.T_{\text {den }}\right)$. Although tenacity of wollen yarns is small the resistance to wear of woolen products is much better than the products made of yarns with higher tensile strength, because of the better structural stability and good resistance to repeated loads [5]. The breaking elongation varies depending on the fineness of the component yarns. The values of the breaking force and the breaking load do not fully reflect the behaviour of yarns (or fibers) to tensile stress. For a more complete characterization the stress-elongation diagram is chosen. During the request, the force variation according to the deformation can be represented graphically as a curve, using for this purpose the dynamometers equipped with recording devices (USTER $®$ TENSOJET 4 - which is a system for measuring the capacity of yarn weaving by the tensile stress in dynamic operation). USTER $尺$ TENSOJET 4 can test the yarns for tensile stress with a speed of $400 \mathrm{~m} / \mathrm{min}$, which is equivalent to $6.7 \mathrm{~m} / \mathrm{s}$.

The mechanical breaking work represents a mechanical work used for yarns deformation (or fiber) to breakage and is equivalent to the area deliniated by the curve, abscissa and parallel to the ordinate carried from the breaking point, and is measured $\mathrm{cN} \cdot \mathrm{cm}$. The mechanical breaking work $L$ (work) is determined by the relation 1 :

In which

$$
L=f \cdot F_{r} \cdot \Delta I_{r} \quad[\mathrm{cN} \cdot \mathrm{cm}]
$$

$f$ - represents the breaking factor;

$F_{r}$ - breaking force $(\mathrm{cN})$;

$\Delta$ / - elongation at break (cm).

The factor of the breaking mechanical work is a dimensionless value that indicates the deformability of the yarn.

Tensile strength is one of the basic characteristics of the yarn, because it influences the behaviour of yarns in processing (preparation for weaving, weaving or knitting) determining the technological parameters of equipment adjustment and their productivity. Also, the yarns tensile strength represents a characteristic quality because its value depends on the product's quality made of it.

Considering the aspects mentioned above, in this paper there were analysed the woolen yarns (breaking strength), strain properties of some wollen yarns

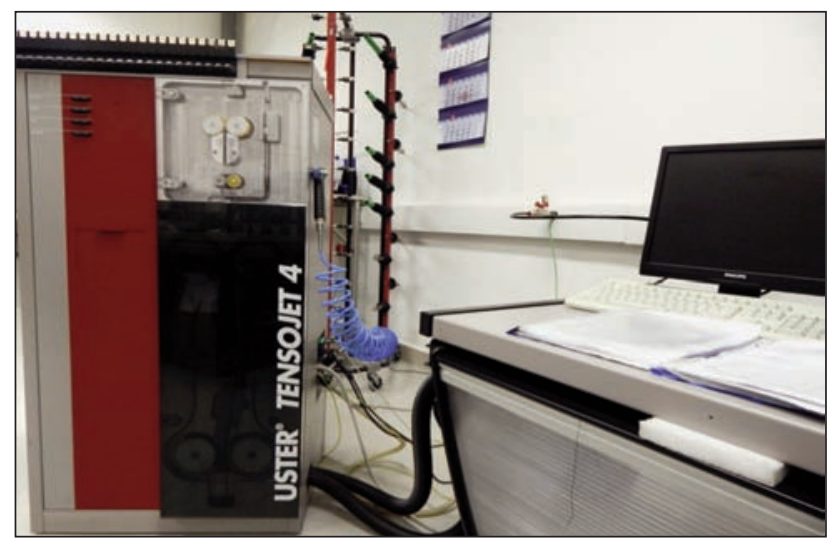

Fig. 1. Device USTER® TENSOJET 4

mixed with elastomer ( $75 \%$ wool and $25 \%$ elastomer), bleached and dyed (colour), that is subject to chemical and thermal treatments. These yarns are intended for knitting processes and have length density $T_{\text {tex }}=29.41$ tex $(\mathrm{Nm} \mathrm{31/1})$ with torque $T=470$ twists $/ \mathrm{m}$. The $25 \%$ elastomer component (SE) of this mixture is meant to improve the elastic properties of the woolen yarns in order to obtain the knitted product with improved elasticity. A comparative study was conducted between two groups of yarns, the first batch being white yarns, and the second batch being colored yarns (dyed). Test analysis of stress properties (breaking strength, elongation at break, toughness and mechanical breaking work) were made out of the ten samples for each batch of yarns. They were made using the device USTER $®$ TENSOJET 4 shown in figure 1. The technical characteristics were presented in another paper [6].

Based on the analyses conducted on two groups of yarns, this data has been processed statistically and mathematically determining the coefficient of variation for strain properties.

The irregularity of the resistance measured by the coefficient of variation to the breaking load (resistance) influences the behaviour of yarns to processing, determining the working capacity of the knitting machine and product quality by the number of nodes. The importance of this index, from a practical point of view is apparent from the fact that is reflected in the quality norms by the maximum acceptable value.

Testing conditions: tests done 10/500; testing speed $400 \mathrm{~m} / \mathrm{min}$; pretensioning $14.7 \mathrm{cN}$.

Figure 2 shows the diagram of dispersion of the breaking force for the yarns of batch 1, showing the irregularity of the tear strength for the ten samples of white yarns.

Figure 3 shows the dispersion diagram of the elongation at break for the yarns of batch 1 , showing the irregularity of the elongation at break for the ten samples of white yarns. Each Stroke diagram shows the maximum and minimum force, elongation determined on each yarn of the ten tested because the main purpose of the high-speed testing is to identify the weak points from the yarns.

Figure 4 shows the force for strain-elongation diagram (Scatter Plot) that shows the tractive and elongation 


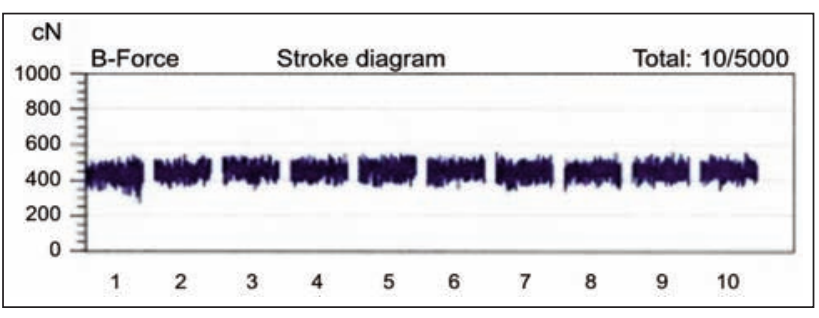

Fig. 2. Dispersion diagram of breaking force for white yarns

force at break for ten white yarns in batch 1, and comprises all the values of the force and elongation determined by the tests performed.

Table 1 shows the individual values of the tensile forces of the ten samples of white yarns and the elongation at break corresponding to these forces. Based on these data the statistical and mathematical processing of this individual data is calculated, thus obtaining toughness, arithmetic mean, coefficient of variation for white yarns in batch 1 . These are shown in the table 1 where: B-Force $(\mathrm{cN})$ is breaking force; Elong (\%) - elongation at break; Tenacity (cN/tex) the breaking toughness; B-Work $(\mathrm{cN} \cdot \mathrm{cm})$ - represents the mechanical work of deformation at break.

Figure 5 shows the dispersion diagram of breaking strength for yarns in batch 2, showing the breaking strength irregularity for the ten samples of dyed yarns. Figure 6 shows the dispersion diagram of elongation at break for the yarns in batch 2 , showing the irregularity of elongation at break for the ten samples of dyed yarns.

Figure 7 shows the force-elongation (stress-strain) diagram (Scatter Plot) that shows the tractive and elongation at break force for ten dyed yarns in batch 2 , and comprises all the strength and elongation values determined by tests. A particular aspect of this diagram is represented by the isolated weak portions from the yarn, showed in the left side of the representation.

Table 2 shows the individual values for the application of tensile forces of the ten samples of dyed yarns and the elongation at break corresponding to these forces. Based on this data the statistical and mathematical processing of the data is achieved, thus obtaining individual tenacity, arithmetic mean, coefficient of variation, for yarns in batch 2 . They are shown in the table 2 where: B-Force $(\mathrm{cN})$ is breaking force; Elong (\%) - elongation at break; Tenacity

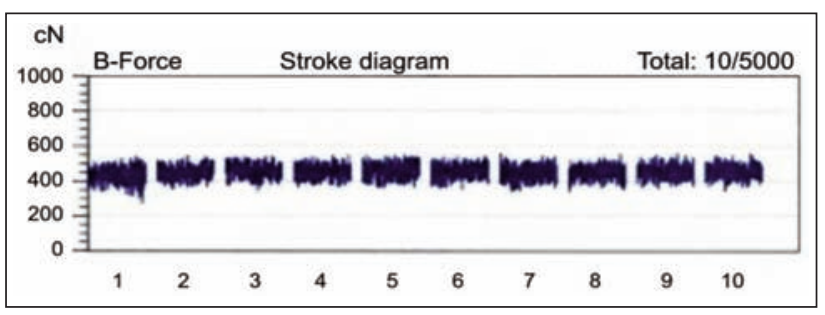

Fig. 5. Dispersion diagram of breaking force for dyed yarns

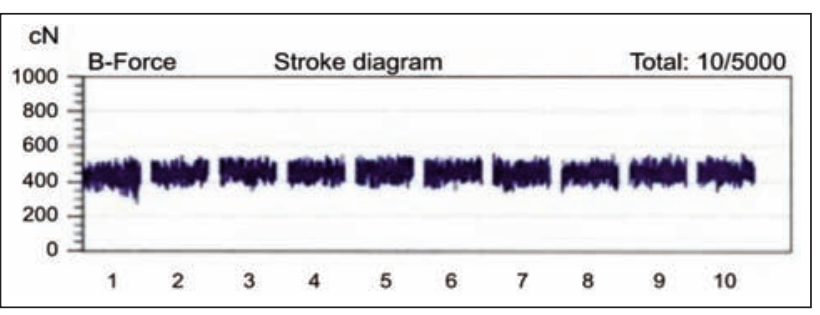

Fig. 3. Dispersion diagram for elongation at break for white yarns

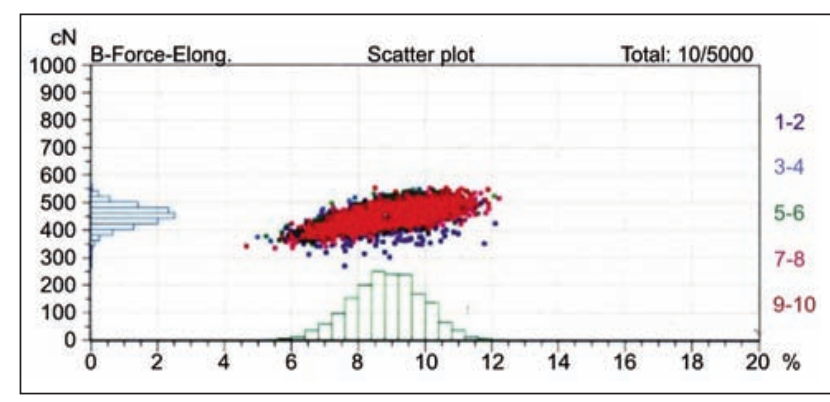

Fig. 4. Dispersion diagram force-elongation of white yarns

Table 1

\begin{tabular}{|c|r|r|r|r|}
\hline \multicolumn{5}{|l|}{ Total: 10/5000 Single test(s) } \\
\hline $\mathrm{Nr}$ & $\begin{array}{c}\text { B-Force } \\
\mathrm{cN}\end{array}$ & $\begin{array}{c}\text { Elong. } \\
\%\end{array}$ & $\begin{array}{c}\text { Tenacity } \\
\text { cN/tex }\end{array}$ & $\begin{array}{c}\text { B-Work } \\
\text { cNcm }\end{array}$ \\
\hline $1 / 500$ & 430.9 & 8.77 & 14.65 & 1253 \\
\hline $2 / 500$ & 445.5 & 8.69 & 15.15 & 1274 \\
\hline $3 / 500$ & 456.0 & 8.72 & 15.51 & 1306 \\
\hline $4 / 500$ & 453.9 & 8.73 & 15.43 & 1305 \\
\hline $5 / 500$ & 456.9 & 8.76 & 15.54 & 1314 \\
\hline $6 / 500$ & 456.0 & 9.13 & 15.50 & 1358 \\
\hline $7 / 500$ & 447.9 & 9.01 & 15.23 & 1324 \\
\hline $8 / 500$ & 447.8 & 8.87 & 15.23 & 1308 \\
\hline $9 / 500$ & 447.8 & 8.94 & 15.23 & 1328 \\
\hline $10 / 500$ & 451.4 & 8.95 & 15.35 & 1323 \\
\hline Mean & 449.4 & 8.86 & 15.28 & 1309 \\
CV & 7.95 & 12.02 & 7.96 & 19.31 \\
s & 35.74 & 1.07 & 1.22 & 252.8 \\
Q95 & 0.991 & 0.03 & 0.03 & 7.009 \\
Min & 267.8 & 4.66 & 9.11 & 459.8 \\
Max & 551.9 & 12.21 & 18.77 & 2161 \\
P0.01 (0) & & & & \\
P0.05 (2) & 310.3 & 5.23 & 10.55 & 546.7 \\
P0.1 (5) & 316.1 & 5.52 & 10.75 & 604.7 \\
P0.5 (25) & 348.4 & 6.05 & 11.85 & 694.9 \\
\hline
\end{tabular}

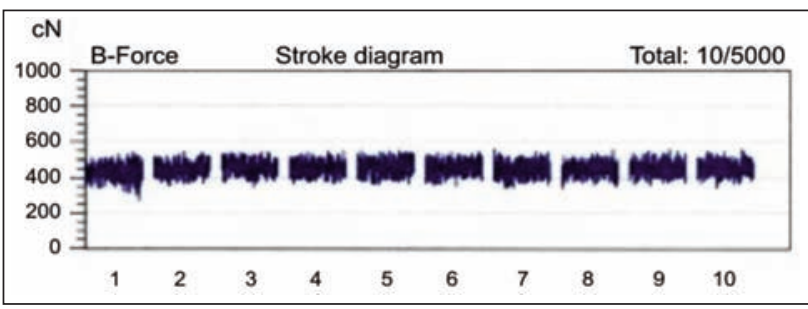

Fig. 6. Dispersion diagram of elongation at break for dyed yarns 


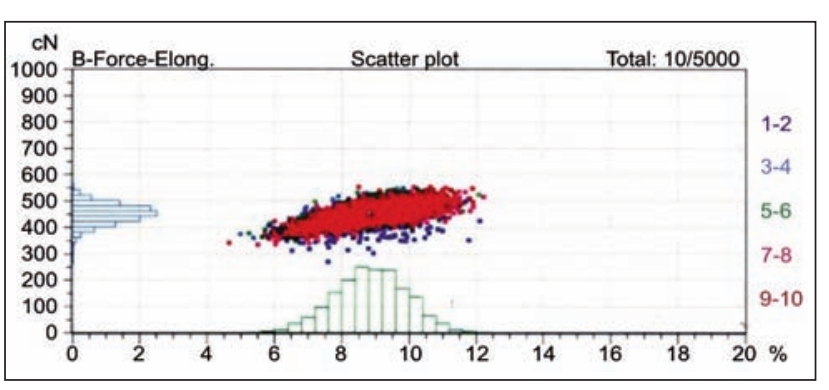

Fig. 7. Dispersion diagram for force-elongation of dyed yarns

(cN/tex) - the breaking toughness; B-Work $(\mathrm{cN} \cdot \mathrm{cm})$ represents mechanical work of deformation at break.

\section{RESULTS AND DISCUSSIONS}

For the first batch of white yarns: the average breaking strength is $449.4 \mathrm{cN} \mathrm{CV}$ for resistance $=7.95 \%$; average elongation at break is $8.86 \mathrm{~cm}$ and $\mathrm{CV}$ elongation $=12.02 \%$; the average tenacity is $15.28 \mathrm{cN} /$ tex and CV tenacity $=7.95 \%$; the average mechanical breaking work is $1309 \mathrm{cN} \cdot \mathrm{cm}$ and CV mechanical work $=19.31 \%$.

For the second batch of dyed yarns (colour): average breaking strength is $451.5 \mathrm{cN}$ and $\mathrm{CV}$ for resistance $=7.6 \%$; average elongation at break is $8.35 \mathrm{~cm}$ and $\mathrm{CV}$ elonagtion $=11.23 \%$; the average tenacity is $15.35 \mathrm{cN} /$ tex and CV tenacity $=7.60 \%$; the average mechanical breaking work (Work) is $1239 \mathrm{cN} \cdot \mathrm{cm}$ and CV mechanical work $=18.33 \%$.

\section{CONCLUSIONS}

Following the research performed on the two batches of yarns it was found that the strain properties (tensile strength, elongation at break, tenacity, breaking mechanical work) have quite similar values with a small difference in the batch of the bleached yarns having tensile strength lower than the dyed yarn

\begin{tabular}{|c|r|r|r|r|}
\hline \multicolumn{1}{|c|}{} & Table 2 \\
\hline \multicolumn{7}{|c|}{ Total: $10 / 5000$ Single test(s) } \\
\hline Nr & $\begin{array}{c}\text { B-Force } \\
\text { cN }\end{array}$ & $\begin{array}{c}\text { Elong. } \\
\%\end{array}$ & $\begin{array}{c}\text { Tenacity } \\
\text { cN/tex }\end{array}$ & $\begin{array}{c}\text { B-Work } \\
\text { cNcm }\end{array}$ \\
\hline $1 / 500$ & 459.5 & 8.32 & 15.62 & 1252 \\
\hline $2 / 500$ & 459.0 & 8.19 & 15.61 & 1229 \\
\hline $3 / 500$ & 451.8 & 8.39 & 15.36 & 1247 \\
\hline $4 / 500$ & 446.2 & 8.36 & 15.17 & 1228 \\
\hline $5 / 500$ & 447.0 & 8.38 & 15.20 & 1235 \\
\hline $6 / 500$ & 459.7 & 9.53 & 15.63 & 1289 \\
\hline $7 / 500$ & 447.3 & 9.30 & 15.21 & 1213 \\
\hline $8 / 500$ & 446.5 & 8.30 & 15.18 & 1218 \\
\hline $9 / 500$ & 448.6 & 8.37 & 15.25 & 1233 \\
\hline $10 / 500$ & 449.1 & 8.40 & 15.27 & 1245 \\
\hline Mean & 451.5 & 8.35 & 15.35 & 1239 \\
CV & 7.60 & 11.23 & 7.60 & 18.33 \\
s & 34.30 & 0.94 & 1.17 & 227.1 \\
Q95 & 0.951 & 0.03 & 0.03 & 6.297 \\
Min & 297.7 & 4.28 & 10.12 & 410.8 \\
Max & 590.7 & 11.17 & 20.08 & 2029 \\
P0.01 (0) & & & & \\
P0.05 (2) & 310.6 & 4.53 & 10.56 & 437.7 \\
P0.1 (5) & 327.3 & 4.83 & 11.13 & 507.0 \\
P0.5 (25) & 364.0 & 5.72 & 12.38 & 666.8 \\
\hline
\end{tabular}

(colour) and an increased sensitive irregularity. It follows that the modern technological processes of bleaching, the yarns are not damaged as compared with those dyed having very close strain properties, although the whitening is known to be more aggressive form a physical point of view on the yarns compared to those from the dyeing process.

The problem in the test sample is given by the variation of elongation values which do not use the yarn at a lower quality level but may be an indicator that deserves attention because it is slightly above the imposed average quality.

\section{BIBLIOGRAPHY}

[1] Bordeianu, L., Fibre textile, Editura Universității din Oradea, 2005.

[2] Gribincea, V., Bordeianu, L., Fibre textile - proprietăți generale, Editura Performantica, laşi, 2002.

[3] Avram, M., Avram, D., Bahu, L., Structura firelor, Editura Gh. Asachi, Iaşi, 2002.

[4] Antoniu, Gh., Arnăutu, I., Fibre Textile. Aplicații. Vol. 2, Editura Dosoftei, laşi, 2002.

[5] Avram, M., Avram, D., Structura şi proprietățile firelor, Editura CERMI, laşi, 1998.

[6] Oana, D., Suteu, M., Oana, I., The study of irregularity elongation of yarns of wool in mixture with silk using the Uster ${ }^{\circledR}$ Tensojet 4 Machine. Annals of the University of Oradea, Fascicle of Textiles-Leatherwork, Oradea, vol. XVI, nr. 2, 2015, pp. 51-56.

\section{Authors:}

Lecturer eng. PhD. IOAN PAVEL OANA ${ }^{1}$

Lecturer eng. PhD. MARIUS SUTEU 1

Lecturer eng. PhD. DORINA OANA ${ }^{1}$

Ass. profesor PhD. DAN MIRICESCU ${ }^{2}$

${ }^{1}$ University of Oradea

Faculty of Power Engineering and Industrial Management

Department of Textile Leather and Industrial Management

2 University Lucian Blaga Sibiu

Str. B. Şt. Delavrancea, no. 4, 410058, Oradea, Bihor, România

e-mail: oanaioanpavel@yahoo.com 


\section{Performance of the pilling evaluation method based on the technique of DFF}

În articolul anterior, am reconstruit imaginea detaliată a țesăturii pe baza metodei de focalizare pe adâncime (DFF), a pilingului segmentat și a pufului de pe fondul țesăturii. Studiul din această lucrare a fost efectuat folosind imaginea cu adâncime de focalizare. Este demonstrat aici procesul de predicție a evaluării pilingului utilizând un număr mare de probe de țesătură. Mașina cu vectori suport (SVM) a fost utilizată pentru a construi mașina de clasificat prin consultarea datelor existente. Metoda grid search a fost utilizată pentru a selecta valorile optime ale parametrilor.

Studiul a demonstrat că cea mai bună precizie a predicției poate ajunge la $90,75 \%$, indicând faptul că pilingul extras din imaginea cu adâncime de focalizare poate face o predicție adecvată a gradului acestuia.

Cuvinte-cheie: piling țesătură, focalizare pe adâncime, imagine cu adâncime de focalizare, mașină cu vectori suport

\section{Performance of the pilling evaluation method based on the technique of DFF}

In previous work, we reconstructed the depth image of fabric based on the method of Depth from Focus (DFF) and segmented pills and fuzz from fabric background. Work in this paper was performed using the segmented image. Here, we demonstrate the prediction operation of the pilling evaluation using a large set of fabric samples. The support vector machine (SVM) was applied to build the classifier machine by learning from existing data. The grid search method was used to select the optimal parameter values. The study found that the best prediction accuracy can reach $90.75 \%$, indicating the extracted pilling features from depth image can predict the pilling grade well.

Keywords: fabric pilling, depth from focus, depth image, support vector machine

\section{INTRODUCTION}

Pilling is the process by which small spherical balls of entangled loose fibers form on the surface of the fabric, due to mechanical abrasion on its surface [1]. Pilling of fabrics has been a problem for a long time, so most of the studies in the testing of fabrics involve pilling evaluation. Pilling became an even more serious problem after the development and wide use of man-made fibers in textiles, due to their higher tensile strength [2]. Researchers worldwide have been exploring techniques to isolate pills from the sample background and assess the pilling grade based on the digital images.

In an earlier work, we have presented a method for extracting pills based on the depth image of fabric. The depth image was reconstructed from multiple layers captured at different focal positions by digital camera under an optical microscope. Pills can be identified with a dynamic threshold of height values in the depth image. In this paper, we further evaluate the method to investigate its performance in fabric pilling grading.

Pill density, average size, and height are the main pill properties that visual observers use to rate the pilling grade of a fabric [3]. Soon Young Yun extracted three parameters including the number of pills, the total pixel area of pilling and the sum of the gray values [4]; Deng tested many parameters including energy feature and shape feature [5]; Junmin proposed the energies of detail sub-images as a quantitative measurement of the number and height of the fuzz and pills [6]. In this paper, the energy feature, pill density and total pilling volume were tested to assess pilling.

SVM is a supervised learning system that is developed from statistical learning theory [7]. This twodimensional learning system is a linear classifier machine whose learning strategy is to maximum the difference of two types, determined by solving a convex quadratic programming problem. The input examples are known as training data, and the output would be desired classified value. And the training samples are initially specified by sets of known attribute values and their respective outcome [8].

Initial investigations suggested that pilling was successfully identified and extracted by the depth map reconstructed by using the method of DFF. This paper aims to evaluate the pilling grades of real fabrics, using a combination of image energy, pill density and total pilling as input parameters to a trained SVM model.

\section{EXPERIMENTAL WORK}

\section{Samples and preparation of the image}

The evaluation method of pilling resistance referred in this study is based on Chinese Standard GB/T 4802.1-1997. Specimens are fixed on the cycle abrasion tester and run for a fixed number of cycles. The 


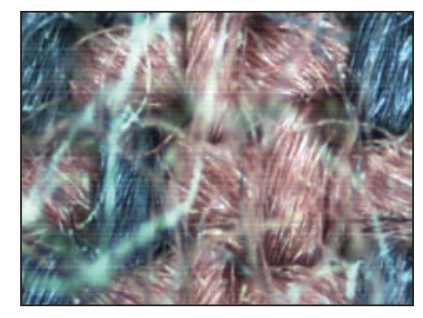

a

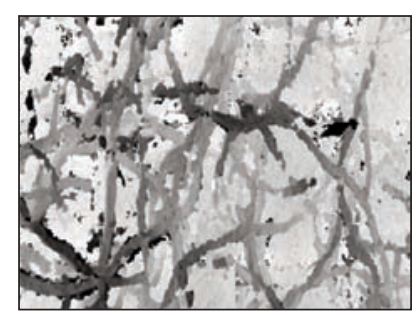

c

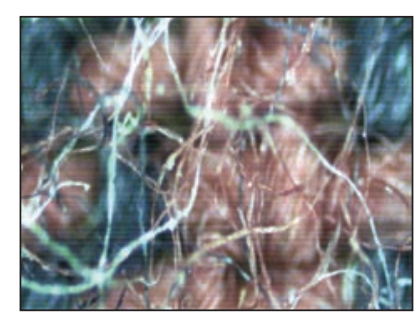

b

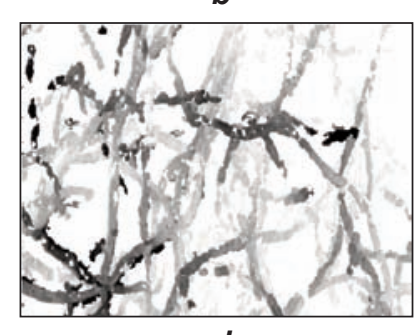

d
Fig. 1. The captured image of fabric and extracted pills and fuzz

standard consists of a verbal description of each pill grading from 1 to 5 degree, 72 knitted and woven fabric samples, including 10 samples in grade 1,9 samples in grade 2, 18 samples in grade 3, 22 samples in grade 4 and 13 samples in grade 5 , were used to be assessed by the Pilling evaluation system and verify its performance. Each fabric test sample was imaged under $4 \times$ lens to capture an image revealing fuzz clears. The images were scaled to $800 \times 600$ pixels in size and 24-bit grayscale in format.

A segmented image was used for extracting characteristic values. The segmented image is not an absolute binary image. The segmented image is obtained by replacing pixel grey values that lower than a threshold with 255 , and reducing the other original pixels grey values by the threshold. Therefore, the grey value of each pixel indicates the pixel height. The intensity of fabric background is 255 , and the intensity of pills and fuzz varies according to their height values. Figure 1 shows the captured images under microscope and the extracted pilling image. Figure $1, a$ indicates the representative layer of image where most fabric background is in-focus. Figure $1, b$ illustrates a layer of image where most pills are focused. Figure 1,c shows the reconstructed depth image and figure $1, d$ conveys the segmented image containing pills and fuzz.

\section{Character identification}

The characteristic parameters in fabric pilling can be extracted in frequency domain or in spatial domain. In frequency domain, researchers reconstruct the image by using Fourier or wavelet transform, and then calculate the energy of each reconstructed detail sub-image. In spatial domain method, many morphological features, such as the total area, size and height, are proposed as the quantitative measures to indicate pills and fuzz. In this paper, five parameters were selected as the characteristic parameters, which are the covering area, the volume and the roughness.

\section{(1) Covering area rate}

The covering rate reflects the area of pills and fuzz in the detected section. The area of pills and fuzz is expressed in terms of number of pixels with non-255 gray values in the picture. The calculated area would be affected by the resolution ratio of the image and the total area of detected section. Therefore, the covering rate was used as a relative index to describe the pills and fuzz.

$$
C=N /(W \times H)
$$

Where: $C$ is the covering rate, $N$ - the number of pixels with non-255 gray values, $W$ - the pixel width of the image and $\mathrm{H}$ - the pixel height of the image.

\section{(2) Volume}

The volume is defined as the accumulative height values of each pilling pixel. The volume is also divided by detected area. The expression can be described as follows:

$$
V=\sum_{i=1}^{i=W} \sum_{j=1}^{j=H} h_{i j} /(H \times W)
$$

Where, $V$ is the volume of pills and fuzz, $h_{i j}$ - the height value of pixel at $(i, j), W$ - the pixel width of the image and $H-$ the pixel height of the image.

\section{(3) Roughness}

Roughness is another important factor influencing pilling appearance. In this paper, roughness $R$ can be determined by the following equation:

$$
R=\sqrt{\sum_{i=1}^{W} \sum_{j=1}^{H}\left(h_{i j}-\bar{h}\right)^{2}} /(H \times W)
$$

In order to make fuzz display clearly, the images used for analysis were captured under $4 \times$ lens to magnify objects. However, at the same time, the magnification would narrow the field of vision. In this paper, the image is $800 \times 600$ pixels in size. Since the pixel resolution is $2 \mu \mathrm{m}$, the actual size of a single field of vision is $19 \times 10^{5} \mu \mathrm{m}^{2}$. Considering the size of one pill is $0.3 \times 0.3 \mathrm{~mm}^{2}$, the undersized area of one single field would increase the randomness of pills, leading to a poor stability of the evaluation algorithm. Therefore, several views were stitched together to form a larger detected section. In this paper, the detected section was constituted by 20 connected views.

\section{Pilling evaluation with SVM}

The Support Vector Machine is often used to solve the problem of classifying data by self-learning. The theory of the method is mapping the input vector into a higher space, and then establishing an optimal hyper plane. The key point of a SVM is finding the most suitable hyper plane to separate two types of data as far as possible.

The following figure illustrates the optimal hyper plane. Due to the fact that a narrow margin would increase the possibility of overfitting, the maximal principle was used in selecting the optimal hyper 


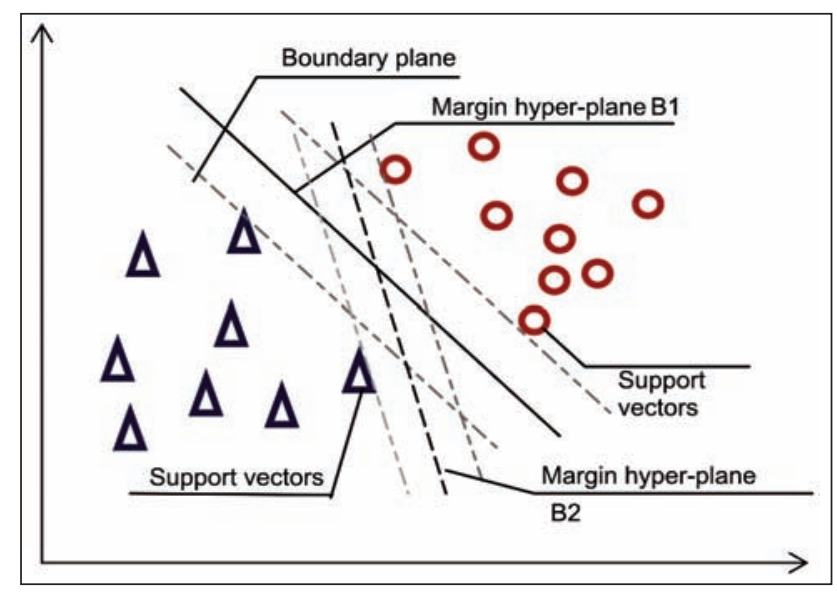

Fig. 2 The SVM classifier

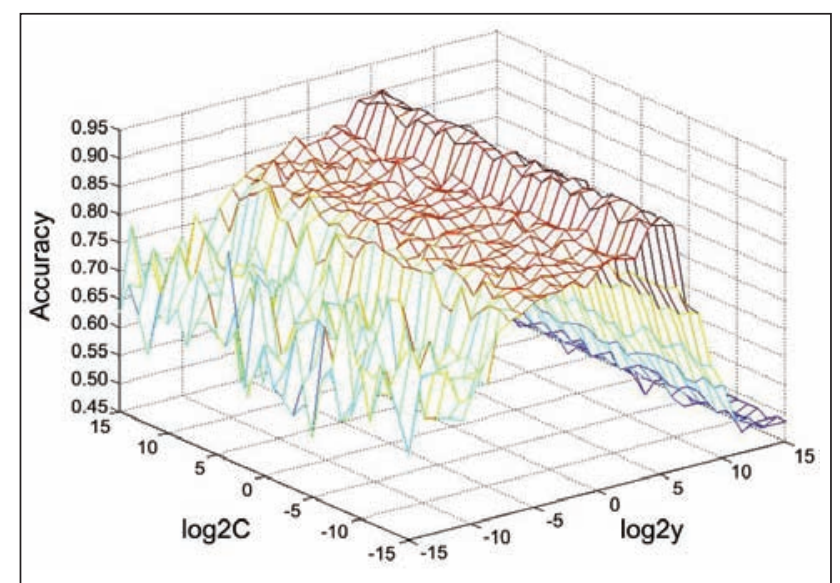

Fig. 3. The $(\gamma, C)$ grid search contour map plane. The maximal principle believes that the wider the margin is, the less the error rate would be. In figure 2, margin hyper-plane B2 is superior to B2. B2 is more likely to build an overfitting classifier, which happens when the model overfits train data by predicting an exact value for sample record from the same training document, but predicts a haywire value if an unseen record is used for testing.

Vapnik has discovered in his research that the choice of kernel functions does not much affect the prediction accuracy, while the choice of related parameters does [9]. The grid search technique was used to find the optimal model parameter values. We first made comparisons of different nuclear parameters $\gamma$ and penalty factor $C$ values, which varied from $2^{-15}$ to $2^{15}$. For each combination of model parameter, we ran all the 216 sets of feature vectors to determine the optimal parameter values. The prediction accuracy is obtained through cross-training. The v-fold crosstraining is a common strategy to separate the data set into v subsets of equal size, of which one subset is considered unknown.

In the process of v-fold cross-training, we divide the data set into 12 subsets, each of which contains 18 characteristic vectors. In the first step, one subset was picked randomly as the unseen set and tested using the classifier trained by the remaining 11 subsets. In the next step, another subset was picked and tested using a new classifier trained by remaining subsets. In the cross-training, the training has been conducted for 12 times and each data was tested.

Figure 3 shows that the SVM achieved from $45.09 \%$ to $90.75 \%$. The best prediction accuracy was achieved at several parameter combinations such as $\left(\gamma=2^{5}, C=2^{4}\right), \quad\left(\gamma=2^{5}, C=2^{21}\right)$ and $\left(\gamma=2^{15}, C=2^{24}\right)$, From figure 3 , it can been seen that a rise of prediction accuracy occurs when $\gamma$ approaches $2^{5}$, and proceeds to fall when $\gamma$ exceeds $2^{5}$, suggesting that the model parameter $\gamma$ affects the performance of our prediction model much.

\section{RESULTS}

This study employed the classification method for predicting the pilling grades of fabric using the SVM. 72 knitted and woven fabric samples, including 10 samples in grade 1, 9 samples in grade 2, 18 samples in grade 3, 22 samples in grade 4 and 13 samples in grade 5 , were used in this study. For each fabric, 3 detected sections constituted by 20 connected views were picked to extract characteristic vectors. The SVM is allowed to learn from the input parameters data and build a classifier for predicting unknown data. The RBF kernel function was used in SVM training. Grid search results suggested that several parameter combination such as $\left(\gamma=2^{5}, C=2^{4}\right), \quad\left(\gamma=2^{5}\right.$, $\left.C=2^{21}\right)$ and $\left(\gamma=2^{15}, C=2^{24}\right)$ can achieve the best prediction accuracy. The best prediction accuracy can reach to $90.75 \%$, thus, our experimental results suggests that the characteristic feature extracted from the depth image can assess the pilling grades well.

\section{Acknowledgements}

The authors would like to express their appreciation for the Natural Science Foundation of China (Grant No.61172119), the Program for New Century Excellent Talents in University (Grant No. NCET-12-0825), the Foundation for the Author of National Excellent Doctoral Dissertation of PR China (Grant No. 201168), the Fundamental Research Funds for the Central Universities of China, and the Subsidization Project (14JS039) of Shaanxi Province Education Department Science and Technology Research Plan.

\section{BIBLIOGRAPHY}

[1] Cooke W.D., Pilling attrition and fatigue, In: Textile Research Journal,1985, vol. 55, pp. 409-414

[2] Ozer G., Fabric pilling performance and sensitivity of several pilling testers, In: Textile Research Journal, 2012, vol. 72, pp. 625-630 
[3] Özdemir H., The effects of yarn and fabric structural parameters on the seam slippage, abrasion and pilling properties of double woven upholstery fabrics, In: Industria Textila, 2012, vol. 63. pp. 307-314

[4] SY.Y., S K., KP C., Development of an objective fabric pilling evaluation method. I. Characterization of pilling using image analysis, In: Fibers and Polymers, 2013, vol. 14, pp. 832-837

[5] Z.D., L.W., X.W., An integrated method of feature extraction and objective evaluation of fabric pilling, In: Journal of the Textile Institute, 2011, vol. 102, pp. 1-13

[6] Junmin Z., Xungai W., Start P., Objective pilling evaluation of wool fabrics. In: Textile Research Journal, 2007, vol. 7, pp. 929-936

[7] Xu, B., Instrumental evaluation of fabric pilling. In: Textile Research Journal, 1997, vol. 88, pp. 488-500

[8] C D., M T., Integrated visual-smart inspection system for the textile fabrics developed by image virtual processing methods. In: Industria Textila 2009, vol. 60, pp. 134-145

[9] C C., V V., Support-vector networks. In: Machine Learning, 1995, vol. 20, pp. 273-297

\section{Authors:}

LingJie $\mathrm{Yu}^{1}$

RongWu Wang ${ }^{1,2}$

JinFeng Zhou ${ }^{1}$

Donghua University

${ }^{1}$ Donghua University, Department of Textile Engineering

2 Xi'an Polytechnic University , Functional apparel fabric Key Laboratory of Shaanxi Province e-mail: lunwenzhuanyou@126.com

Corresponding author:

RongWu Wang

wrw@dhu.edu.cn

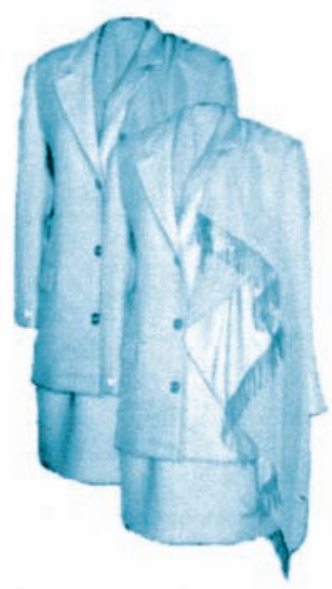




\title{
Constructional, performance and social characteristics of contemporary Slovenian wedding dress
}

\author{
DOI: 10.35530/IT.068.01.1309
}

\section{REZUMAT - ABSTRACT}

\section{Caracteristici de contrucție, performanță și sociale ale rochiei de mireasă contemporane din Slovenia}

\begin{abstract}
În prezent, rochia albă de mireasă se bucură încă de o mare popularitate în rândul mireselor din diverse culturi și societăți. Este prezentată ca o manifestare magică a tot ceea ce este sacru. Pe de altă parte, idealurile populare nunții tradiționale de culoare albă sunt puternic promovate și în mod constant prezentate în numeroase filme și reality showuri, reviste şi reclame. Cultura rochiei de mireasă contemporane și moda din Slovenia sunt create în saloane de nuntă cu colecții proprii care sunt închiriate și care urmează tendința populară la nivel global a nunților occidentale în culoare albă. Scopul cercetării a fost de a studia semnificațiile simbolice ale rochiei albe de mireasă din Slovenia și de a explora și a identifica caracteristicile de construcție, performanță și sociale ale acesteia. A fost utilizată abordarea metodelor mixte. În primul rând, a fost utilizată o analiză critică a discursului (CDA) pentru a identifica semnificațiile simbolice ale rochiei albe de mireasă, în contextul relațiilor dintre sexe. În plus, o abordare cantitativă a fost realizată cu scopul de a evalua prezența și puterea elementelor identificate anterior. În cercetarea calitativă, au fost identificate elementele simbolice ale rochiei albe de mireasă contemporane: imobilizare, dependență, delicatețe, lipsa autenticității și caracteristicile exagerate ale corpului mireselor. Rezultatele cercetării cantitative au dovedit că toate elementele simbolice identificate sunt foarte puternic prezente în moda contemporană a mireselor din Slovenia.
\end{abstract}

Cuvinte-cheie: rochie de mireasă, modă mirese, analiza critică a discursului, semnificație simbolică, conotație, ideal de frumusețe

\section{Constructional, performance and social characteristics of contemporary Slovenian wedding dress}

The white wedding dress is still very popular among today's brides from many cultures and societies. It is still presented as a magical manifestation of all that is sacred. On the other hand, popular white wedding ideals are strongly advertised and constantly presented in numerous movies and reality shows, magazines and commercials. Contemporary bridal culture and fashions in Slovenia are created in wedding salons with their rental collections, which follow the globally popular trend of Western white weddings. The purpose of the research was to study the symbolic meanings of the white wedding dress in Slovenia, and to explore and identify its constructional, performance and social characteristics. The mixed methods approach was used. First, critical discursive analysis (CDA) was used to identify the symbolic meanings of the white wedding dress in the context of gender relations. Additionally, a quantitative approach was conducted with an aim to evaluate the presence and strength of previously identified elements. In the qualitative research, symbolic elements of the contemporary white wedding dress: entrapment, dependency, slenderness, inauthenticity and exaggerated attributes of brides bodies were identified. The results of the quantitative research proved that all identified symbolic elements are very strongly present in contemporary Slovenian bridal fashion.

Keywords: wedding dress, bridal fashion, critical discourse analysis, symbolic meaning, connotation, beauty ideal

\section{INTRODUCTION}

The white wedding dress is still very popular among today's brides from many cultures and societies. A traditional design based on the pre-modern romantic belief seems to be resilient and prevalent, even among those who prefer original and unique approaches. As we know it today, the white wedding dress emerged and became popular in the nineteenth century after the marriage of Queen Victoria and Albert of Saxe-Coburg in 1840. The royal bride wore a long white wedding dress with veil and orange blossoms, which became the most desirable and valued wedding image - a symbol of true romantic love and purity [1]. The popularity of the white wedding dress in Anglo-American and European society is therefore ascribed to Queen Victoria. The white colour of her wedding dress signified purity, as was common in Britain in the early nineteenth century. By the early twentieth century, however, with increasing secularisation in Britain and America, brides became less concerned about displaying their status in the colour of their gown [2].

Nowadays, the prevailing colour of wedding dresses in Western culture is white or ivory. The well-established term white wedding encapsulates the occasion of the entire wedding and its Christian religious tradition, which includes a ceremony followed by a reception [3]. In our research, the term white wedding dress is used for a long female wedding dress of bright colour (white, ivory, bright blue, bright pink, etc.), which presents a popular Western design, the style of which has flourished globally.

Otnes \& Pleck argue that brides want lavish weddings because they wish to experience this magic in 
their lives [3]. Evidently, culture has a profound influence on the manner in which individuals perceive each other, and how they perceive the limits imposed by society and their place within it [4]. A white wedding dress is still presented as a magical manifestation of all that is sacred [5]. The authors interpret the white wedding as a secular yet sacred event that brings together consumer culture and romantic love in the form of magical modern transformation. On the other hand, popular white wedding ideals can be interpreted as rampant commercialism. Such ideals strongly advertised and spread worldwide - are constantly presented in numerous movies and reality shows, magazines and commercials; therefore helping to spread their popularity. Hypnotic images of brides inspire lust for imaginary fantasy weddings, lavishness, and magic, therefore constantly interpolating the audience; and in these images, a long white wedding dress is the only right and socially appropriate choice.

\section{BRIDAL FASHION IN SLOVENIA}

This part of the research was completed between 2012 and 2013 in Slovenia - where bridal fashions are well known to the researcher. Then, the research has been continued and focused on the design and planning of the alternative unique bridal fashion collection; the publication of results is planned for the near future.

Typical wedding dresses in Slovenian bridal fashion are white and ivory, following the global popularity of Western wedding dresses. Some weddings in Slovenia are based on Christian religious tradition, which includes a ceremony followed by a reception; others are based on formal procedures according to the constitution, while some other weddings include both elements. Slovenian brides prefer to rent wedding dresses, instead of buying them. With that purpose, many bridal salons were established in Slovenia with the aim of renting wedding dresses and all the associated services: cleaning, measuring, making adjustments and selecting accessories. In this way, the Slovenian bridal fashion actually contributes to sustainability; rental as a type of re-use slows the consumption and the need for the costly and energy consumptive manufacturing processes of new products [6]. Bridal culture and fashions in Slovenia are therefore created by wedding salons with their rental collections, which are imported from foreign producers (China, Italy, England, France, etc.); they all follow the globally popular trend of Western white weddings.

\section{EXPERIMENTAL}

\section{Research objective}

The purpose of the study was to examine the symbolic meanings of the white wedding dress, and to explore and identify its characteristics and beliefs, in the context of gender relations. This symbolic meaning or, as Barthes defines it, a connotation, refers to ideologies within a particular culture and often justifies the relation of power and subordination, which appear to be like the works of nature [7]. Working for over ten years with the white wedding brides, who are customers of Atelje Princ - a bridal salon in Ljubljana, Slovenia - gives us the opportunity to thoroughly observe their position and behaviour. Surprisingly, we noticed that the white wedding dress, in some cases placed the bride in a subordinate gender position, resulting in a need for research and criticism. Thus, we decided to undertake an interdisciplinary study of the white wedding dresses and their symbolic meaning and characteristics in the context of gender relations. A qualitative approach was deemed appropriate to recognize characteristics, elements and mechanisms of the white wedding dress. Additionally, quantitative research was conducted with an aim to evaluate the presence and strength of previously identified elements.

\section{Research methods}

On the basis of the information obtained from theoretical literature framework, as well as on the basis of experience working with the brides who were the customers of Atelje Princ bridal salon in Slovenia, the mixed methods approach was used, with its combination of quantitative and qualitative research methods [8, 9]. The methods are based on different paradigms or epistemologies (positivist versus interpretive) [8-13]. We have undertaken the mixed method approach in order to develop a deep insight into the white wedding dress phenomenon that cannot be fully understood or objectively presented if only one method was used.

First we used the qualitative critical discursive analyses, which enables us to have a deeper understanding of the white wedding dress phenomena and the gap related to the meanings of white wedding dresses and issues of gender relations [14]. The open nature of the critical discourse analysis (CDA), which is characterised by a critical attitude towards unproblematic acceptance of knowledge, is important for our study because it enables interdisciplinary interpretations, whilst addressing issues of gender relations created by the white wedding dress [15]. The CDA's critical purpose is based on a wide variety of theories, so an interdisciplinary approach from different theoretical backgrounds is fundamental for in-depth analyses. The eclectic nature of CDA enables us to have a certain freedom when developing new perspectives, but it focuses on the following main concepts: discourse, ideology, hegemony, and context. The CDA method takes place on the three main levels (figure 1), but we have redefined it by analysing clothes as cultural texts (figure 2) [14].

According to Fairclough, Level 1 is a descriptive level and a linguistic analysis of a text [14]. Level 2 is the interpretational level of a text. Level 3 gives social clarification and it explains a textual discourse in relation to ideology, hegemony, and power.

Qualitative findings were, in the second phase, evaluated in a quantitative way where content analysis was used. Content analysis is based on explicit rules 


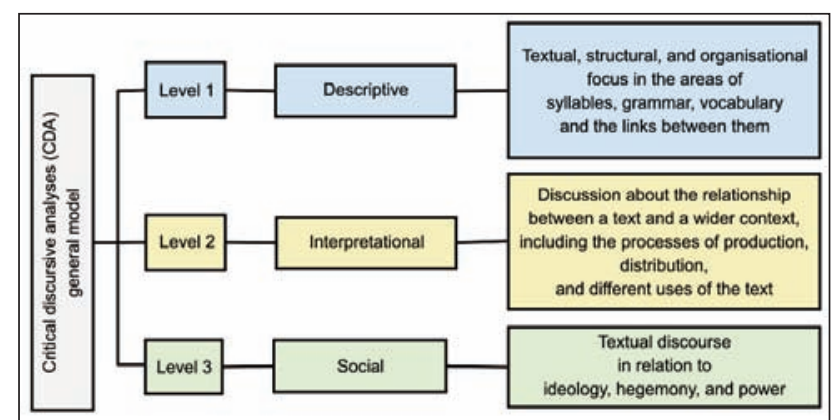

Fig. 1. General 3-level concept of the critical discursive analyses (CDA)

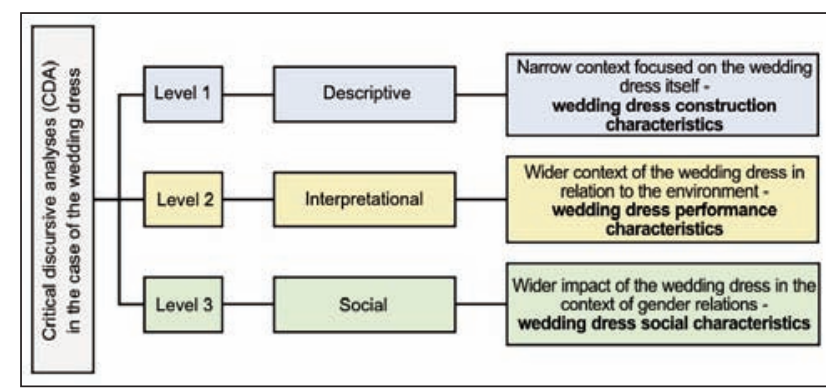

Fig. 2. Redefined 3-level concept of the critical discursive analyses (CDA) - the case of the wedding dress

of coding and on a systematic, objective, and replicable technique used for describing the manifested contents of communication [16-18]. The mixedmethod approach used in our study is important, because it maximizes the strengths and minimizes the weaknesses of each of these two approaches.

\section{Data collection}

From all the bridal salons in Slovenia known to offer white wedding dresses, we identified the five financially most successful salons in the year 2012. We have used the Slovenian financial database (http:// www.bizi.siw.bizi.si/) to select the five bridal salons with the highest income in 2012, working on the assumption that they are the most popular salons in Slovenia. Further data was collected using online web pages of the salons, where their latest collections have been presented for commercial purposes. We accessed the web pages in June 2013. From each web page of each of the salons, we selected the first three models, and we worked on the assumption that these three receive the most exposure and therefore the most attention from future brides. Our data collection therefore consisted of 15 models of white wedding dresses from the most popular bridal salons in Slovenia, and are representative of Slovenian bridal fashion. Hence, a total of 15 wedding dresses were critically analysed on the basis of the three different levels suggested by Fairclough [14].

\section{RESULTS AND DISCUSSION}

\section{Qualitative critical discursive analyses}

On the basis of the qualitative critical discursive analyses (CDA) method (figure 1), we analysed the

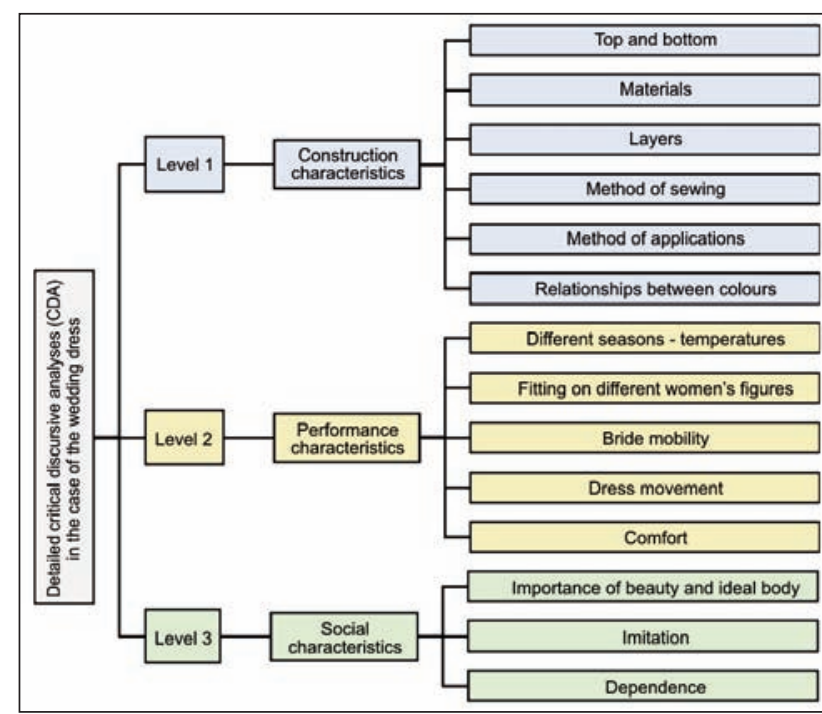

Fig. 3. Critical discursive analyses (CDA) - analysed elements of the wedding dress

selected wedding dresses at three levels (figures 2 and 3) [14]. Level 1 as a descriptive level requires a textual, structural, and organisational focus, featuring syllables, grammar, vocabulary, and the links between them (figure 1).

In our study, level 1 was a descriptive analysis of the construction of the wedding dress (figure 3): top, bottom, materials, layers, methods of sewing, methods of applications, relationships between colours, and other recognized characteristics. According to the CDA general model, level 2 as an interpretational level of a text contains a discussion about the relationship between a text and a wider context, including the processes of production, distribution, and different uses of the text (figure 1). In our study, we have analyzed the following performance characteristics (figure 3): a wedding dress in different seasons (temperatures), a wedding dress on different women's figures, bride mobility, movement, and comfort. Level 3 generally explains a textual discourse in relation to ideology, hegemony, and power (figure 1). In our study, level 3 has identified meaning behind the wedding dress in the context of a wider impact of a certain dress, on the relationships in today's society: importance of beauty and ideal body, imitation and dependence (figure 3).

On level 1, further analysed CDA results showed that the construction of the contemporary white wedding dress in Slovenia can be described in more detail as follows:

- emphasised breasts with decorations, emphasized hips and buttocks;

- corset, stiff belt, boat collar, long trail, veil;

- slimmer princess A-line, very slim mermaid shape;

- asymmetrical lines, emphasized S-line of silhouette, emphasized longitudinal lines of silhouette;

- polyester taft, polyester sateen, polyester lace;

- large amounts of plastic pearl decorations, floral voluminous decoration in polyester organdie, small button decoration in the back;

- white or ivory colour, addition of black colour; 
- short dress, one shoulder dress, bare shoulder dress;

- huge voluminous skirt, multiple layers of the dress, heaviness of the dress.

After the construction of the contemporary wedding dress in Slovenia was defined in more detail, further CDA was performed on the level 2. The results showed that the contemporary white wedding dress in Slovenia can be critically interpreted as follows:

- multilayered synthetic dresses are not appropriate for summer weddings in hot temperatures;

- multilayered bottom petticoats, stiff corsets in the top half of the dress, or slim mermaid silhouettes create clumsy movement and can immobilize the bride;

- poor synthetic materials and large amounts of plastic in the form of pearls placed in an over-thetop manner, create an inauthentic appearance;

- juxtaposition of wide petticoats and stiffness of corsets creates discomfort;

- the tight mermaid silhouette creates a movement of the bride that is not autonomous;

- fragile and feminine silhouettes accompany other exaggerated feminine physical characteristics (breasts, buttocks, hips and tight waist);

- slimness is emphasized by longitudinal lines, S lines of silhouettes are emphasized;

- heaviness of the dress disables the free movement of the bride.

On the basis of the first two levels, the interpretation of the wedding dress in relation to the society, along with the impact on gender relations, was performed on the level 3. Symbolic meaning, messages to the society and gender relations characteristics of the white wedding dress in Slovenia were identified as:

- entrapment,

- dependency,

- slenderness,

- inauthenticity and

- exaggerated attributes of bride's body.

\section{Quantitative content analysis}

In the second part, previously identified symbolic elements were evaluated in a quantitative way - on the basis of content analysis. Content analysis is a systematic, objective, replicable technique used for describing the manifested contents of communication, and it is based on explicit rules of coding [16-19]. Content analysis can be any technique which is used for making inferences by objectively and systematically identifying specified characteristics of messages, and it can be applied to other areas which are not restricted to the domain of textual analysis. In order to allow for the replication, however, the technique can only be applied to data that is durable in nature. Many researchers used content analysis for analysing the contents of pictures and photographs [20-23].

A total of 15 wedding dress models representing our data collection were evaluated in terms of the intensity for each symbolic element. A coding sheet was used, developed for the study. We categorised the level of intensity of each individual element using a numerical scale with values from 1 to 5 , where number 1 signifies the minimum presence of the element and number 5 signifies the maximum presence of the element in a specific dress. The level of intensity for each element within 15 models of wedding dress of our data collection was determined. In total, 75 intensities were evaluated and later calculated in percentages. First, the reliability of the coding was determined. Two researchers independently evaluated the intensities of symbolic elements in the first three dresses ( $20 \%$ of the data collection). The reliability of the coding was calculated by dividing the agreements by total items (agreements plus disagreements). A reliability of $95 \%$ was found, and thus relative reliability was established. On the basis of this result, the primary researcher continued to evaluate the rest of the dresses of data collection. For the purpose of coding accuracy, all evaluations were made three times [24]. The analysis aimed to evaluate intensity of previously identified symbolic elements and has shown the following (figure 4): entrapment: $82 \%$, dependency: $76 \%$, slenderness: $68 \%$, inauthenticity: $88 \%$, exaggerated attributes of bride's body: $71 \%$.

Our qualitative identification of the symbolic elements and their strong quantitative presence in the collections of our study case provide some new insights into the meanings and power of ideology in the context of a contemporary white wedding dress in Slovenia.

The symbolic element of inauthenticity had in the strongest intensity (88\%) among all recurring symbolic elements of our data collection. Wedding dresses made of synthetic materials, mendacious silhouettes of princesses and mermaids and large quantities of plastic pearls and decorations are highly inauthentic products. Therefore, it could be established that shoddy and mass-produced wedding dresses cause the individuality of future brides to drift into a fantasy and a numb state of comfort and deprive them of their experience as an autonomous individual.

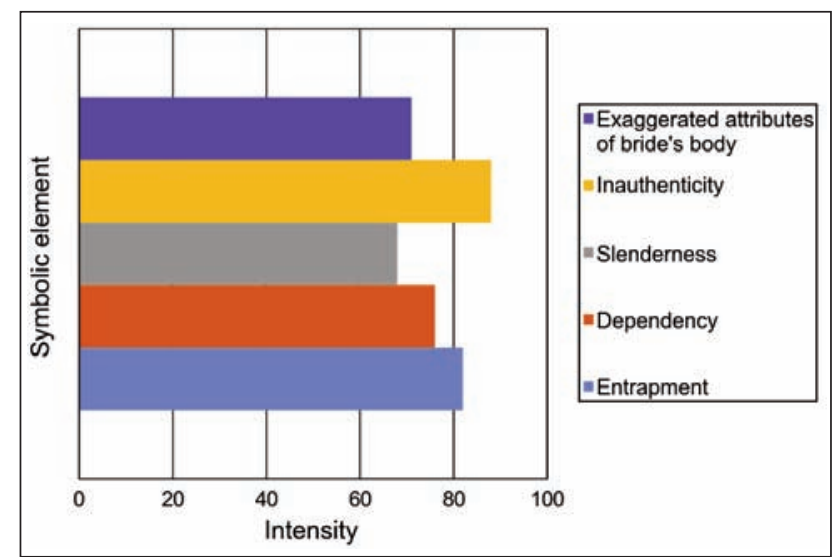

Fig. 4. The intensity of the symbolic elements of the wedding dress 
The second strongest symbolic element was entrapment, measured with an intensity of $82 \%$ and mainly manifested in forms of stiff, tight corsets. In the frames of reality and long-term benefits, brides take the decision to wear the white wedding dress as an internalization of general moral standards and ideals. The third symbolic element is dependency, with an intensity of $76 \%$ and which mainly showed as a result of the different clothing elements; stiffness of a corset and a voluminous, heavy, layered skirt with wide petticoats, which prevent a bride from moving freely, trains or elongated tails or immobile mermaid silhouettes. Wedding dresses with these elements constrict a bride as a dependent being, and render her into someone who needs support and assistance during the ceremony and throughout the wedding day.

The fourth strongest mechanism with an intensity of $71 \%$ is manifested in the form of exaggerated attributes of the bride's body. By highlighting body parts with the help of laces, ornaments, large quantities of decorations, and corsets, a juxtaposition of an unnaturally thin waist and emphasized hips is obtained.

The last in the terms of intensity - but still a strong symbolic element - is slenderness, with intensity of $68 \%$. In our research, emphasizing slenderness represents a burden for brides, which preoccupies them by constantly triggering the feelings of imperfection and the unsuitability of their bodies. Brides invest time, energy and money into unhealthy beauty routines in order to change their bodies to comply with an expected ideal.

\section{CONCLUSIONS}

The results of the research showed that all identified symbolic elements: entrapment, dependency, slen- derness, inauthenticity and exaggerated attributes of bride's body are strongly present in the contemporary Slovenian bridal fashion. The qualitative identification of the symbolic elements and their strong quantitative presence in the collections provides some new insights into the meanings and power of ideology in the context of a contemporary white wedding dress in Slovenia. Our interdisciplinary study shows how the identity of an individual woman can be constructed by a fashion that defines her reality. It also shows how fashion can recreate the relations of power and subordination between the genders. A bride renounces her own identity and accepts the hegemonic symbolic meaning of a white wedding dress, which seems to be lavish and magical [3].

In our study, content analysis links the selected theoretical concepts with research and practice, as suggested by Pedersen [25] in order to provide a deeper insight into the white wedding dress phenomenon and a better understanding of the white wedding dress ideology. Findings and results of this study can be used in designing future wedding collections, as a proposal to select more intelligent, individual and authentic concepts and contribute to more equal gender relations.

Further research could be conducted to include an analysis of wedding collections of world corporations and to address cultural, racial, occupational and educational stratifications of brides, as well as an analysis of the impact of the white wedding dress on human behaviour as suggested by Johnson, Yoo, Kim, \& Lennon [26]. Further research has already been conducted to set better values for the development of an intelligent, individual and an authentic wedding collection for women of today, who are developing their identity with her their uniqueness and dignity.

\section{BIBLIOGRAPHY}

[1] Ehrman, E. The wedding dress: 300 years of bridal fashions, In: V\&A Publishing, London, 2011

[2] Church, K. Something plain and simple? Unpacking custom-made wedding dresses from Western Canada (1950-1995), In: Wedding Dress across Cultures, Berg, Oxford, 2003

[3] Otnes, C., \& Pleck, E. H. Cinderella dreams: The allure of the lavish wedding, In: University of California Press, Berkeley, 2003

[4] Popescu, Doina, I. Green fashion - a new possible lifestyle for Romanians. In: Industria textilã, 2013, vol. 64, issue 1 , pp. $46-54$

[5] Friese, S. The wedding dress: From use value to sacred object, In: Berg, Oxford, 2001

[6] Cuc, S., Girneata, A., Iordanescu, M., Irinel., M. Environmental and socioeconomic sustainability through textile recycling. In: Industria Textilã, 2015, vol. 66, issue 3, pp. 156-163

[7] Barthes, R. Mythologies, In: Vintage, London, 1993

[8] Tashakkori, A., \& Teddlie, C. Issues and dilemmas in teaching research methods courses in social and behavioural sciences: A US perspective. In: International Journal of Social Research Methodology, 2003, vol. 6, issue 1, pp. 61-77

[9] Creswell, J. W., Plano Clark, V. L., Fetters, M. D., \& Morales, A. Mixed methods intervention trials, In: John Wiley and Sons, New York, 2009

[10] Brannen, J. Mixed methods for novice researchers: Reflections and themes. In: International Journal of Multiple Research Approaches, 2009, vol. 3, issue 1, pp. 8-12 
[11] Bryman, A. Barriers to integrating quantitative and qualitative research. In: Journal of Mixed Methods Research, 2007, vol. 1, issue 1, pp. 8-22

[12] Datta, L.E. Paradigm wars: A basis for peaceful coexistence and beyond. In: New Directions for Program Evaluation, Special Issue: The Qualitative-Quantitative Debate: New Perspectives, 1994, vol. 61, pp. 53-70

[14] Fairclough, N. Critical discourse analysis: The critical study of language, In: Longman, London, 1995

[15] Burr, V. An introduction to social constructionism, In: Routledge, London, 1995

[16] Berelson, B. Content analysis in communication research, In: Free Press, New York, 1952

[17] Krippendorff, K. Bivariate agreement coefficients for reliability of data. In: Sociological Methodology, 1970, vol. 2, pp. $139-150$

[18] Neuendorf, K. Content analysis: A methodological primer for gender research. In: Sex Roles, 2011, vol. 64, issue 3-4, pp. 276-289

[19] Holsti, O. R. Content analysis for the social sciences and humanities, In: Addison-Wesley, Reading, 1969

[20] Al-Olayan, F. S., \& Karande, K. A content analysis of magazine advertisements from the United States and the Arab world. In: Journal of Advertising, 2000, vol. 29, issue 3, pp. 69-82

[21] Field, S. L., Bauml, M., Wilhelm, R. W., \& Jenkins, J. Folk dress, fiestas, and festivals: How is mexico portrayed in U.S. Primary grade social studies textbooks? In: The Journal of Social Studies Research, 2012, vol. 36, issue 1, pp. 22-46

[22] Seels, B., Good, B., \& Berry, L. Recognition and interpretation of historically significant news photographs. In: Journal of Visual Literacy, 1999, vol. 19, issue 2, pp. 125-138

[23] Webb, S. Art commentary for the middlebrow: Promoting modernism \& modern art through popular culture - how Life magazine brought "The new" into middle-class homes. In: American Journalism, 2010, vol. 27, issue 3, pp. $115-150$

[24] Minjeong, K., \& Lennon, S. J. Content analysis of diet advertisements: a cross-national comparison of Korean and U.S. women's magazines, In: Clothing \& Textiles Research Journal, 2006, vol. 24, issue 4, pp. 345-362

[25] Pedersen, E.L. Theory is everywhere: A discourse on theory. In: Clothing and Textiles Research Journal, 2007, vol. 25, issue 1, pp. 106-128

[26] Johnson, K. K. P., Yoo, J. J., Kim, M., \& Lennon, S. J. Dress and human behaviour: A review and critique. In: Clothing and Textiles Research Journal, 2008, vol. 26, issue 3, pp. 3-22

\section{Authors:}

\section{IRENA FUNDUK ${ }^{1}$}

Dr. ALENKA PAVKO-ČUDEN, Assoc. Prof. ${ }^{2}$

${ }^{1}$ Atelje Princ, Irena Funduk Fashion

Karlovška 1a, 1000 Ljubljana, Slovenia

e-mail: ateljeprinc@siol.net, irena.funduk@siol.net

${ }^{2}$ University of Ljubljana

Faculty of Natural Sciences and Engineering

Department of Textiles, Graphic Arts and Design

Aškerčeva 12, 100 Ljubljana, Slovenia

e-mail: alenka.cuden@ntf.uni-lj.si

Corresponding authors:

ALENKA PAVKO-ČUDEN

alenka.cuden@ntf.uni-lj.si 


\section{Design of an electronically equipped sailing garment for improved safety}

\section{Design-ul echipamentului de navigație cu funcții electronice, pentru o siguranță îmbunătățită}

În ultimele decenii, s-au dezvoltat diverse articole de îmbrăcăminte inteligente cu funcții electronice care urmează să fie utilizate în medicină, armată și divertisment. Unele dintre aceste articole de îmbrăcăminte conțin dispozitive electronice clasice și au fost numite dispozitive purtabile. În plus, unele studii au fost realizate prin introducerea proprietăților funcționale direct în materialele textile. Aceste cercetări sunt limitate și se află încă în curs de desfășurare, din cauza problemelor de durabilitate a efectului funcțional și a altor probleme tehnice.

În această lucrare, un sistem electronic a fost dezvoltat și integrat într-un articol de îmbrăcăminte de navigație, în scopul de a asigura acestuia proprietăți funcționale. O astfel de îmbrăcăminte funcțională a fost realizata pentru a creşte siguranța marinarilor. Sistemul electronic a fost conceput pentru a detecta prezența marinarilor de pe navă și pentru a da un mesaj de alarmă în cazul în care aceștia cad în mare. În acest scop, microcontrolere, module Bluetooth, module GPS (Global Positioning System), module GSM (Global System for Mobile Communications) și ecrane au fost utilizate pentru a construi sistemul. De asemenea, un senzor pentru ritm cardiac și un senzor de temperatură au fost adăugați la proiectarea sistemului pentru a obține valorile frecvenței cardiace a marinarilor și pentru a oferi informații despre temperatura mediului înconjurător. Componente electronice miniaturizate au fost utilizate pentru a putea integra întreg sistemul în articolul de îmbrăcăminte. După obținerea unui prototip util, un sistem electronic a fost integrat în echipamentul de navigație fara a afecta impermeabilitatea, greutatea și aspectul îmbrăcămintei originale. Este de așteptat ca utilizarea acestui sistem de îmbrăcăminte funcțional să accelereze operațiunea de salvare și să crească eficiența siguranței marinarilor. De asemenea, acest sistem poate fi adaptat la alte activități de echipă, cum ar fi alpinismul, operațiunile din armată și cele de salvare, și, prin urmare, domeniile de aplicare ale acestui concept pot fi extinse.

Cuvinte-cheie: echipament de navigație funcțional, sistem electronic, detectarea căderii, senzor de ritm cardiac, alarmă de urgență, temperatură ambiantă

\section{Design of an electronically equipped sailing garment for improved safety}

In the last decades, various smart garments with electronic functions were developed to be used in medicine, army and entertainment areas. Some of these garments contained classical electronic devices and they were called as wearable computers. Besides, some studies were done by introducing the functional properties directly to the textiles. But these researches are limited and still in progress because of the durability problems of the functional effect and other technical problems.

In this work, an electronic system was developed and integrated to a sailing garment in order to provide functional properties to the sailing garment. Such a functional garment was produced to enhance the safety of the sailors. The electronic system was designed to detect the sailors' presence on the boat and give an alarm message in case they fall overboard. For this purpose, microcontrollers, Bluetooth modules, GPS (Global Positioning System) modules, GSM (Global System for Mobile Communications) modules and screens were used to build the system. Also a heart rate sensor and a temperature sensor were added to the system design to obtain the heart rate values of the sailors and give information about the temperature of the surrounding environment. Miniaturized sized electronic components were used to be able to integrate the total system onto the garment. After obtaining a useful prototype, an electronic system was implemented to the sailing garment without impairing the waterproofness, low weight and appearance of the original garment. Usage of this functional garment system is expected to speed up the rescue operation and increase the efficiency for the safety of sailors. Also this system can be adapted to other team activities such as mountaineering, soldier operations and rescue teams therefore the application areas of this concept can be broadened.

Keywords: functional sailing garment, electronic system, fall detection, heart rate sensor, emergency alarm, ambient temperature

\section{INTRODUCTION}

Protective garments are produced to protect the wearer against harsh environmental conditions and/or various threats that can cause harm or death [1-3]. According to their end-uses, protective garments can posses one or more functional properties like waterproofness, flame retardancy, ballistic protection, protection against hot/cold weather, resistance to chemicals and etc. In addition to these protective properties, some functional garments can exhibit electronic functions. Garments with electronics can serve for entertainment, medical, safety and communication purposes [4-5]. In this kind of garments, generally, environmental or individual effects are sensed, processed and responded by the garment. For these processes, various sensors and other 
kinds of electronics are implemented to garment design.

Garments with electronic functions are usually divided into two main groups, namely; wearable computers and smart garments. In wearable computers, some hard electronic materials such as sensors, microcontrollers, batteries and interfaces are added to garment after garment production process. On the contrary, smart garments are produced by introducing intelligent properties directly to the garment $[4,5]$. The former approach is preferred more for electronically developed textiles because of its simplicity and applicability. Also producing smart garments has to overcome some durability and technical problems which are caused by external effects such as washing, stretching, construction of textile materials [6, 7]. In the literature, different examples of wearable electronics and smart garments can be found. Electronically equipped vests, t-shirts, jackets, shoes and etc. can be given as examples. Some of these products became commercial within years. For example, Philips developed a LED (Light Emitting Diode) array integrated very flexible fabric, Lumalive, which is proposed to be used in advertising, personal safety, fashion and interior design [8]. Georgia Institute of Technology developed a wearable motherboard to detect the projectile penetration and to monitor the vital signs such as temperature, heart rate and respiration rate of soldiers [9]. Other products for heart rate detection can be in the form of textile hearth rate sensors attached to a bra or vest [10]. Also, smart textiles for noninvasive monitoring of physiological signals were developed [11]. Many works were done on IPod related garments for entertainment area, too. IPod jackets or jeans of Burton [12], Levi's, Bagir [13] and many other companies can be given as examples. Also, as in our study, GPS integrated garments were designed, too. The Know Where Jacket is one of them, possessing a GPS module [12]. Another example can be the research work of Rantanen et.al. (2002), in which a functional garment prototype was prepared for arctic snow car riders [14]. In this research, GSM and GPS modules were used to find the injured rider. In other researches, electronically equipped protective garments such as heating vests, high visible t-shirts, safety gloves, functional fireman garments and etc. were produced [15-18].

Some of the above mentioned examples are produced for sports area. But according to the authors' knowledge, there is no electronically equipped sailing garment in the literature or in the market. Also, there are only a few researches on the sailing garments. One of the rare researches is made by Bye and Hakala [19]. They designed a one piece women sailing garment to enhance the comfort and visual properties of female sailors. Besides there are some patents in which the safety of the sailors were enhanced via buoyancy properties of sailing vests or jackets. One of the oldest patents which are available on this issue is got by Steinthal (1969) [20]. Steinthal used an inflatable $U$ shape segment combined with the sailing jacket. This $U$ shaped segment was designed to float the head of the fallen sailor. A similar patent was got by Jackson (1988) [21]. In Jackson's patent, the inflatable segment was placed inside the jacket and could be inflated by the help of strings. Other patents about sailing garments were got by Kaynor et. al. (1977) [22] and Pankof (1987) [23] about load balancing and easy wear sailing garments, respectively.

In this study, firstly, an electronic system was designed to enhance the safety of the sailors. Differently from the literature, a fall detection system was designed by using Bluetooth communication principles. The electronic system was developed to detect the fallen sailor from the boat, find the falling location and time and send an emergency message. In addition, a heart rate sensor and a temperature sensor were added to the electronic system of this study. Normally, when resting, heart rate values of adults are between 60 and 100 beats per minute. But for sports activity, this value increases over 100 and is usually influenced by some other parameters like oxygen level, air temperature, body position (standing up, sitting down or lying down), emotions, body size, medications and etc. [24]. For example at sea level, the heart rate is lower than the one in higher altitudes [25]. As a result, addition of these two sensors provides sailors to follow their heart rates and learn ambient temperature by using their functional sailing garment.

Before the system development, an emergency scenario was created by the authors to be able to line up the system steps and clarify the emergency response. The final prototype of the system was implemented to a sailing garment successfully.

\section{EXPERIMENTAL WORK}

\section{Materials}

The critical point, in determining the components of the electronic device to be used in a functional garment design, is selecting the optimally sized and optimally weight electronics in order to avoid giving extra weight and extra volume. Otherwise, the mobility and the performance of the sportsmen can be reduced easily. Therefore, miniaturized sized components were selected for creating the electronic system.

The electronic system of this study is consisted of two parts: master system and slave system. Master system is planned to be mounted on the center of the boat. This system contains a master Bluetooth, a GPS module, a GSM module, a microcontroller, a character LCD (Liquid Crystal Display) screen, buttons and a battery. Main aim of the master system is to search for the presence of the sailors on the boat, find the falling time and location of the sailor, and send emergency messages by GSM. The system also takes the temperature and heart rate values from each sailor by communicating slave modules. Besides, the LCD screen of the master system shows the current presence status of sailors, their heart rates and the ambient temperature. Also, 
master system settings can be adjusted by the help of LCD screen and menu button.

The second system part, namely, slave system is consisted of a slave Bluetooth, a microcontroller, a heart rate sensor, a temperature sensor, an OLED screen, on-off switch, a button and a battery. Slave modules were planned to be mounted on the sailing garments. By the communication of the master and slave Bluetooth modules, the electronic system becomes able to detect the fallen sailor. With the help of the heart rate sensor and the OLED screen which are integrated to sailing garment, sailors can see their heart rate values by using their functional garment. In addition, the ambient temperature can be seen in this OLED screen by processing the signals of temperature sensor.

In the following section, details of the master system components and slave system components are given. All the electronic equipments of the study were purchased from Sparkfun.

\section{Bluetooth Module Breakout}

Bluetooth is a low-cost and power efficient multiple device communication standard. One Bluetooth device can control and manage several other devices [26]. In this study, Bluetooth modules were used to detect the presence/absence situation of the sailors on the boat. One Bluetooth module was integrated to the master system to be mounted on the center of the boat. Eight (up to nine) Bluetooth modules were used as slave systems to be mounted on each sailor's garment. The Roving Networks (RN 41) Bluetooth v2.1 EDR modules were used in this study. The weight of the module is 8 grams and the size is $2.54 \times 2.28 \mathrm{~cm}$. Module power consumption is low and module has an onboard RF chip antenna.

\section{GPS module}

GPS receivers are used for positioning, locating, navigating, surveying and determining the time [27]. A 50 channel GS407 Helical GPS Receiver was used in this project in order to find the accurate falling position of the sailor. This module uses a helical antenna with $\mathrm{U}-\mathrm{Blox} 5 \mathrm{H}$ chip set. The GPS module is 16 grams in weight and $4.71 \times 2.29 \mathrm{~cm}$ in sizes. GPS receiver has $2 \mathrm{~Hz}$ update rate and can track 50 satellites. It has less than 1 second hot start-up time and 29 seconds for warm start-up time.

\section{GSM Module}

GSM is a voice and data mobile communication standard [28]. In this study a GSM module was used in the master system to be able to send emergency messages in case any sailors fall overboard. Telit GL865-DUAL GSM kit was selected for this purpose. This module is 23 grams in weight and $5.8 \times 6.2 \mathrm{~cm}$ in sizes. It supports GSM/GPRS 850/900/1800/1900 $\mathrm{MHz}$ Quad-band frequency.

\section{Heart rate Sensor}

A heart rate sensor was used in the study in order to follow the heart rates of sailors during sports. This was important because the lowest the heart rate during sports means the highest the performance of the sailors. For this purpose, a Grove Ear Clip Heart Rate Sensor was used in this study. The sensor can be clipped on to a fingertip or earlobe. Commercially, some other kinds of heart rate sensors could be provided which can measure heart rate from chest or wrist of the wearer. However, these sensors require a very tight, fixed and continuous contact with the skin which cannot be provided by a waterproof sailing top. Because, the waterproof sailing tops are made of coated or laminated woven fabrics, which form loose garments on the body. When moving during sports, the place of these sensors would frequently change on the body and the measurements would be done wrongly because of the poor fit of the garment. For this reason, ear/finger clip type heart rate sensor was selected to be used in this project. Chest type heart rate sensor was not selected due to its difficult wear and relatively more cost. The sensor was planned to be clipped on the earlobe, because the sailors use their hands frequently and harshly. The squeezing force of the sensor is enough to be clipped on the earlobe. Even if the clip splits from the ear during sailing, the sailor can easily clip it back to his earlobe. The heart rate sensor works with the help of a LED and ambient light sensor. During use, LED and light sensor contacts with the skin. The LED shines light into earlobe or other capillary tissue, and sensor reads the light that bounces back. An amplification and noise cancellation circuitry helps to get reliable heart rate readings from the heart rate sensor.

\section{Microcontrollers}

Two different types of development cards were used in the study. One is ATmega 2560 microcontroller based Arduino Mega 2560 card which was used in the master system. The card has 54 digital input/output pins, 16 analog inputs, 4 UARTs, a $16 \mathrm{MHz}$ crystal oscillator, and an USB connection. It can be powered by an AC-to-DC adapter or a battery. This card is 35 grams in weight and $10 \times 5.5 \mathrm{~cm}$ in sizes. The other development card of the study, which was used in the slave systems, was ATmega 328 microcontroller based Arduino Pro Mini. It has 14 digital input/output pins, 6 analog inputs and pin headers. A six pin header can be connected to an FTDI cable or Sparkfun breakout board to provide USB power and communication to the board. Arduino Pro Mini is less than 2 grams in weight and $1.8 \times 3.3 \mathrm{~cm}$ in sizes.

\section{Screens}

The master system has a LCD screen to show the master system information and system settings. The LCD screen is $2 \times 16$ character backlight LCD. The slave system has a micro OLED screen to show the heart rate and ambient temperature to the wearer. The micro OLED screen is $64 \times 48$ pixels Monochrome Blue-on-Black screen.

\section{Batteries}

The master system has an onboard $7.4 \mathrm{~V} 4100 \mathrm{mAH}$ Lithium polymer (Li-Po) battery. The slave system has 3.7 V $1050 \mathrm{mAH}$ Li-Po battery. Li-Po batteries 
were selected because of their high power efficiencies.

\section{Battery chargers}

Li-Po batteries must be charged carefully by the help of designed charger ICs. In this study MCP73831T is used for single cell $3.7 \mathrm{~V}$ Li-Po battery placed in the slave system, MCP73213 is used for dual cell $7.4 \mathrm{~V}$ Li-Po battery placed in the master system.

\section{Methods}

A scenario was created by the authors in order to decide the proper electronic function for the garment. According to the electronic function, the best electronic hardware and software designs were developed by the researchers.

\section{Scenario}

According to the scenario, the presence of the sailors would be detected in certain time intervals and continuously. If any sailor falls overboard, an emergency message would be sent to a rescue center with the coordinates, name and the falling time of the sailor. The scenario is summarized in figure 1. Firstly, to cover detection of all sailors, the midpoint of the boat is determined as shown in figure 1, a. The length of the boat is $2 r$ (figure $1, b$ ). From the midpoint, a safe area is defined with $r$ radius (figure $1, c)$ ). The main electronic system (master system) is placed on the midpoint. 8 slave systems are mounted on each sailors' garments. The master system scans this inquiry area and finds the eight sailors in certain time intervals. If a sailor falls from the boat and gets out of this safe area, connection between master system and slave system is broken (figure 1,e). After this situation, the master system matches and records the corresponding GPS coordinates with the fallen sailor's name and falling time information. This information is sent to an emergency (rescue) center simultaneously by using the GSM module (figure 1, f). By this way, a quick and effective rescue operation will be started. If a sailor falls out of the lateral face of the boat, he/she will go out of the safety area fast because of the movement of the sailboat and will be detected by the master system within a few seconds. If the number of sailors will be higher than eight, then the system can scan the inquiry area with different modes. Three modes are defined for inquiring. This can be controlled by a 6 mode switch in the master system. By manually selecting the modes of switch, eight sailors can be found in each one. So the total number for scanning the sailors in a boat can be increased to 24 by using different switch modes. As the number of sailors in a yacht boat during a sailing race is considered as $8-14,24$ sailors are higher than the required one. Also by power consumption mode, the sailors can be scanned in a narrower area or can be scanned in a wider area. The scenario and the electronic system can be adapted to reduce the safety area. For this, the electronic system can be developed by using one or two more Bluetooth modules in the master system, which will be placed on the different parts of the boat. By the interference and communication of these additional Bluetooth modules with the master microprocessor, the master system

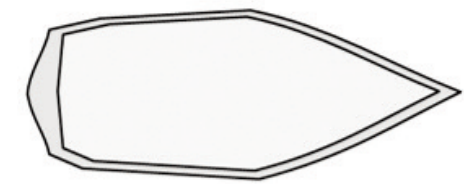

a

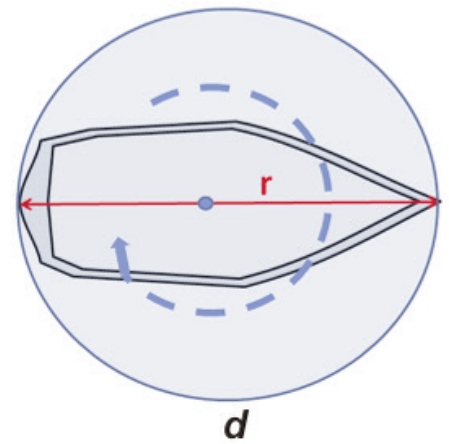

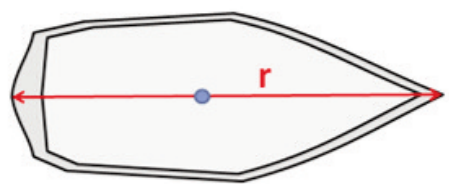

b

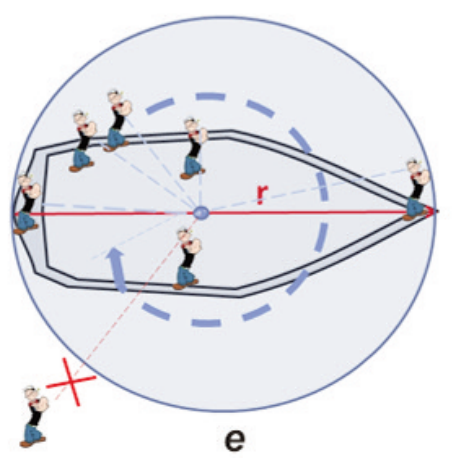

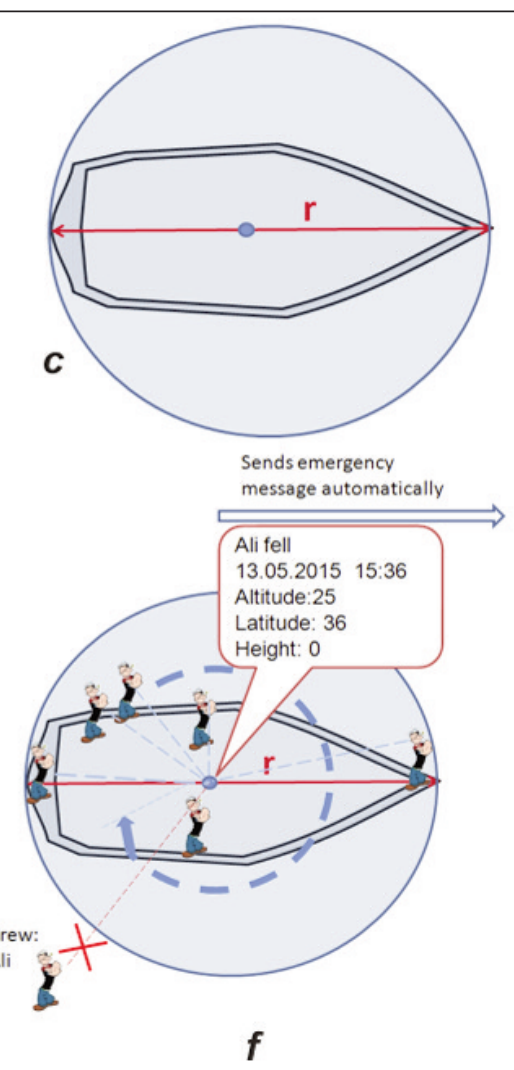

$f$

Fig. 1. The scenario for the system development 
can evaluate the safety in a narrower area. However, this solution needs additional Bluetooth systems, which can cause an increment in the total system costs.

\section{Electronic system design}

Electronic system design is consisted of hardware and software. Hardware and software designs of master and slave systems are given in the following parts, respectively.

\section{- The Hardware Design}

The hardware consists of two systems namely master system and slave systems. The master system is planned to be placed on the center of the sailboat and the slave systems are on the garments of the sailors. Block schematics of the hardware are given in figure 2.

Master system is controlled by Arduino Mega platform. This system can be powered either by sailboat battery or an internal battery. The batteries that would be used must be powerful and feed the system for long durations. In this project master system is fed with a Li-Po internal battery. The master Bluetooth module scans the slave Bluetooth modules in order to detect their presences. The Bluetooth module (RN 41) is powered by $3.3 \mathrm{~V}$ and communicates with Arduino Mega by using serial channel 1. The GSM module (GL-865 DUAL) was connected to Arduino Mega to send emergency SMS (Short Message Service) to a rescue center. The GSM module is powered by $3.3 \mathrm{~V}$ and communicates with Arduino Mega by using Serial channel 2. The GPS module (GS407) detects the location and falling time of the slave modules, which fall out of the inquiry area. GPS module is powered by $3.3 \mathrm{~V}$ and communicates with Arduino Mega by using serial channel 3. GPS module indicates connection status to satellites with a LED. Also buttons and a character LCD are used to determine operation modes and display required information.

Slave system has an Arduino Mini Pro platform, which is used to collect heart rate data, read the temperature sensor and command the OLED screen. Slave system has an internal 3.7 V Li-Po battery which provides long term use. The $3.3 \mathrm{~V}$ voltage regulator on the Arduino Mini Pro powers all the system components. The slave Bluetooth module is controlled by microcontroller and used for presence detection by master system. This module communicates with Arduino Mini Pro with serial channel 0. The OLED module displays the sensory information. The module communicates Arduino with $12 \mathrm{C}$ protocol. There is power on/off switch and a button controls displaying sensory information on the OLED screen only for a determined time for battery saving purpose.

\section{- The Software Design}

Software for master system and slave systems was written by using Arduino $\mathrm{C}$. In the beginning, the master system was able to find any Bluetooth systems in the safe inquiry area. In order to prevent the detection of the Bluetooth modules which are not from the same team, the slave modules are inquired by using

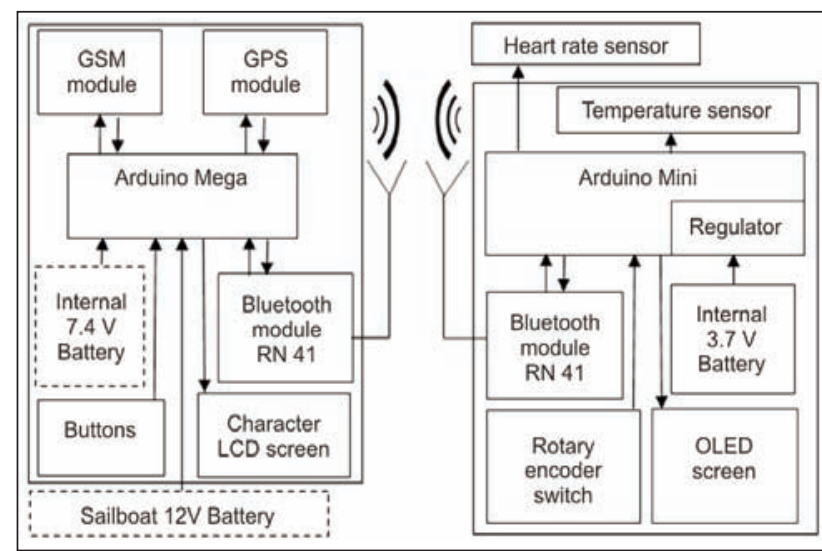

(a) Master system

(b) Slave system

Fig. 2. Hardware block schematics

CoD (Class of Device) values by improving the software. All the Bluetooth modules in the sailing team are defined by the same CoD values where the strangers have different CoD values. After inquiry, master Bluetooth system used to write "Inquiry done" to Arduino receiver buffer. If the letters " $D$ o $n$ e" are received one after another from the buffer, it understands that the inquiry is completed and the online slave module names are detected. If any modules are out of the detection area, the names of these modules are stated as not detected. If any sailor falls from boat, its Bluetooth communication becomes lost and the GSM module is awoken by the microcontroller and it gets the GPS position information from microcontroller and send it to the security unit according to the written software.

In the slave system, software was written to read the value in heart rate sensor and temperature sensor. These sensor values are written to the slave Bluetooth name for master system acquisition. If the show button is pressed, the information is displayed on the slave module OLED screen for only 2 seconds for the sailor view to save the battery.

The basic software algorithms are given in figure 3 . Here, LCD control and LCD message part is not mentioned for simplicity.

\section{- Garment design}

After the development of electronic systems, a sailing garment was modified to be able to mount the slave system on the sailing garment. It was planned to place the slave system inside a waterproof pocket above the cuff of a waterproof sailing top garment. This pocket fixes the module and isolates the module from water. Also this placement does not limit the movement of the sailor. The pocket is sealed with a Velcro cover. The pocket is designed to have a transparent screen window, so the sailor will be able to see his heart rate and ambient temperature from the OLED screen easily during sailing. The pocket is connected to a waterproof inner tube which starts from the upper part of the pocket to the collar of the garment. In the hardware design, the heart rate sensor was connected to the slave system with $2.5 \mathrm{~mm}$ stereo connector. Its cable goes to the neck of the 


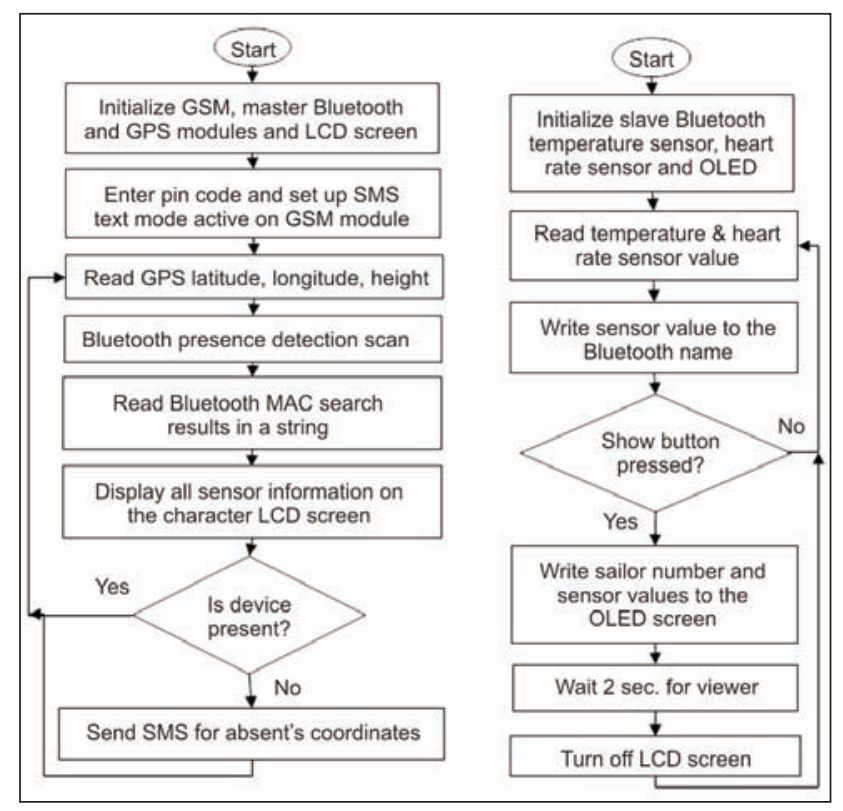

Fig. 3. The basic software algorithm of the master (left) and slave system (right)

garment by using the inner tube. Collar exit of the inner tube is sealed by Velcro. The cable is fixed at the upper side of the garment's neck with a clamp and the heart rate sensor is attached to the earlobe. This approach fixes the heart rate sensor cable and isolates it from water. To be easily washed, the electronic system can be unplugged from the garment and plugged after laundering easily according to this garment design. Placement of the slave system on the sailing garment is represented in the drawing in figure 4. After sewing the designed pocket and the inner tube on the garment, needle holes were closed with a spray adhesive in order to maintain the waterproofness of the sailing garment.

\section{RESULTS}

The resultant prototype of the master system is given in figure 5 . The Master system is placed in a trans-

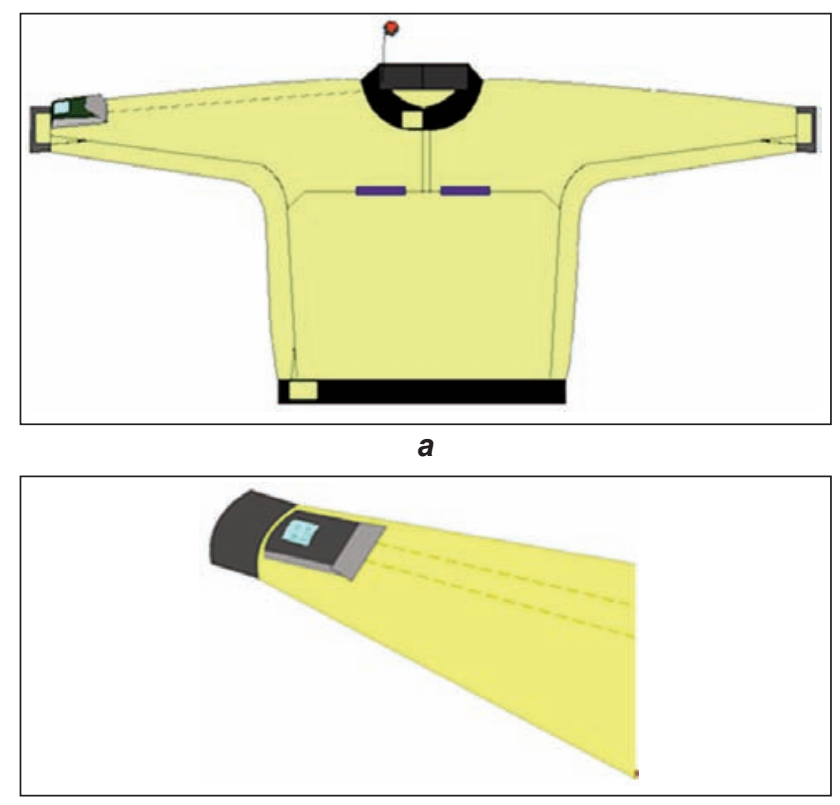

b

Fig. 4. The placement of the slave system on the sailing garment: $a$ - front face of the garment; $b$ - zoomed view of garment sleeve

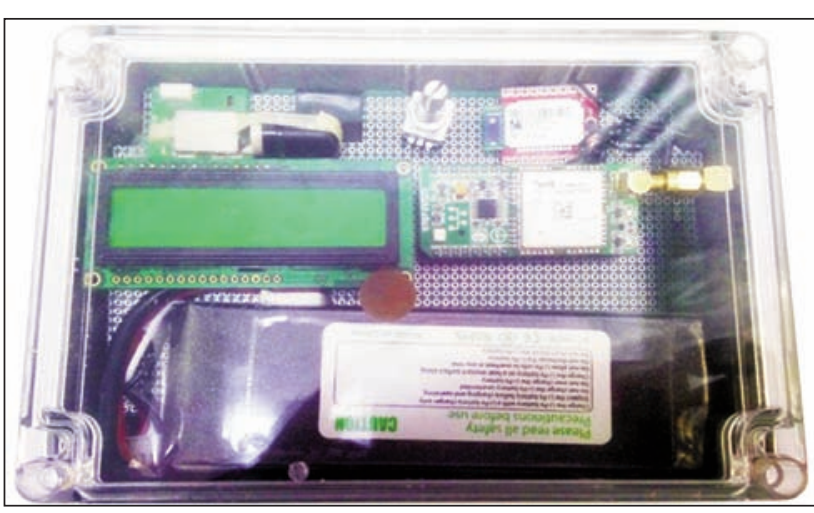

Fig. 5. Prototype of master system

parent waterproof container. So the process of the master system can be followed from the digital screen.

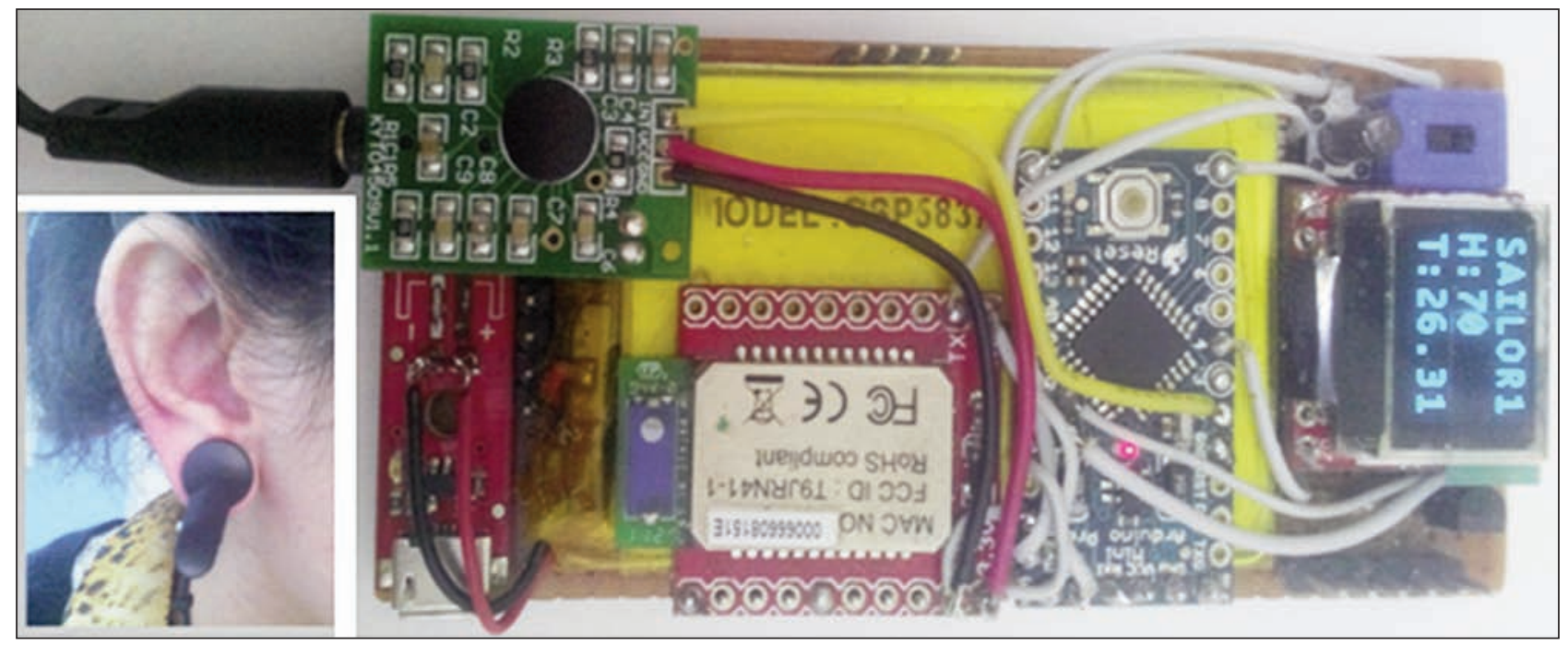

Fig. 6. Prototypes of slave system ( $\mathrm{H}$ : heart rate, $\mathrm{T}$ : ambient temperature) 


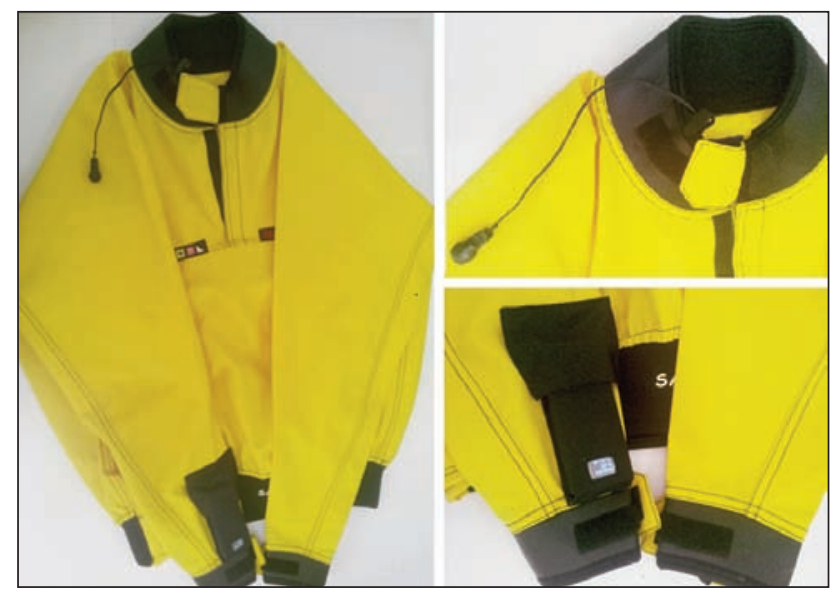

Fig. 7. Electronically equipped sailing garment (left: whole garment, right top: collar and the heart rate sensor clip, right bottom: the slave module inside water-roof pocket)

The heart rate sensor is seen near the collar and there is enough cable to clip the sensor to the earlobe (figure 6). The heart rate value and ambient temperature can be easily seen from the transparent window of the pocket. The slave system was implemented on the garment as in figure 7 . The pocket is made of waterproof laminated fabric Lock stitch is used while sewing. Black color is selected for the pocket fabric so it would be harmonic with the collar and the cuff of the garment.

\section{CONCLUSION}

The hardware elements of the prototypes were gathered together and connected to each other properly. The software was created successfully and worked compatible with the hardware. In the master and slave system prototypes, fall of the crew was detected successfully and emergency message with the name of the fallen crew, falling time and GPS coordinates was sent by the system to a predetermined cell phone number. Heart rates of the sailors and ambient temperature were read on the OLED screen in the sailing garment successfully.

Both the master system which will be placed on the boat, and the slave system which was mounted to the sailor's garment, worked properly and synchronized. The slave system is less than 15 grams without the battery. Master and the slave electronic prototypes were built using breakout cards and their overall weights were higher than specifically designed electronic cards. Even in this case, the weight of the systems is acceptable, but in future works by using specially designed printed circuit boards the weight of the systems can be reduced more. Slave system was mounted on the cuff of the sailing garment as shown in figure 7 . With the addition of an inner tube to the sleeve, attachment of the heart rate sensor to the earlobe of the sailor became possible and easy.

The system is expected to speed up the rescue operation by providing the falling time and position of the sailor as soon as he falls overboard. If necessary, more than 9 crews can be scanned in the boat by using the inquiring mode switch manually. By this way, up to 24 people can be detected by this system. Cost of the prototype electronic system is not very expensive to implement when compared with the cost of the waterproof sailing garments. Moreover, specific electronic card design and printing helps to reduce the cost. Also, the addition of such a safety system increases the added value of the sailing garment which can amortize the cost of the electronics. For this study, yacht racing sailors were selected for scenario design and electronic function. Application areas of this system can be broadened according to the requirements of different areas. For example, this system can be used in rescue boats. So if any of the rescue crews fall over the boat in an emergency state, the master can be informed about this situation. Also, this system can be adapted to be used in mountaineer teams. If any of the mountaineers gets away from the group, this can be detected and the group leader can be warned to find the lost mountaineer.

\section{Acknowledgements}

This project is funded by Dokuz Eylul University via Scientific Research Project (Project Number: 2012.KB. FEN.013). The authors thank for their financial support. Also, authors thank Electrical and Electronics Engineers Murat UCAN and Emin VILGENOGLU for their technical support in electronic system design.

\section{BIBLIOGRAPHY}

[1] Adanur S., Wellington Sears Handbook of Industrial Textiles, Technomic Publishing Company Inc., Lancaster, Pennsylvania, 1995

[2] Scott R. A. Textiles for protection, Woodhead Publishing, Cambridge, England, 2005

[3] Pan N., Sun G. , Functional textiles for improved performance, protection and health, Woodhead Publishing, Cambridge, England, 2011

[4] ShishoO R, Textiles in Sports, Woodhead Publishing, Cambridge England, 2005

[5] Tao X., Wearable electronics and photonics, Woodhead Publishing, Cambridge, England, 2005

[6] Dumitrescu I., Nello L. P., Iordache O. G., Bima G., The influence of the textile materials structure on the screen printed circuits' characteristics. In: Industria Textila, 2014, vol. 65, no. 6, pp. 310-317

[7] Kayacan O., Comparative study about the effect of cleaning processes on the transmission performance of textile based conductive lines. In: Industria Textila, vol. 66, no. 4, pp. 176-183 
[8] Otley M. T., Invernale M. A., Sotzing G. A., Fabric electrochromic displays for adaptive camouflage, biomimicry, wearable displays and fashion; Mortimer R. J., Rosseinsky D. R, Monk, P. M. S. (Eds.) Electrochromic Materilas and Devices, In: Wiley-VCH Verlag GmbH, 2015, p. 518

[9] Park S., Jayaraman S. e-Health and Quality of life: The role of the wearable meotherboard; Lymberis, A., De Rossi, D. (Eds) Wearable e-Health Systems for Personalised Health Management, In: IOS Press, 2004, pp. 243

[10] Black S., Trends in Smart Medical Textiles; Langenhove L. V. (Ed.) Smart Textiles for Medicine and Healthcare: Materials, Systems and Applications, Woodhead Publishing, Cambridge, England, 2007, pp. 13-17

[11] Onose G., Anghelescu A., Chendreanu C., Onose L., Neacsu A., Haras M. et. al. Smart textiles for noninvasive monitoring of physiological signals. In: Industria Textila, 2009, vol. 3

[12] Hurford R.D. Types of smart clothes and wearable technology, McCann J, Bryson D. (Eds.) Smart Clothes and Wearable Technology, Woodhead Publishing, Cambridge, England, 2009, pp. 28-29

[13] Ji Y.G., Lee K. Standardization for smart clothing technology, GILSOO Cho (Ed). Smart Clothing: Technology and Applications, CRC Press, Boca Raton. 2009, pp. 69

[14] Rantaten J., Impio J., Karinsalo T., Malmivaara M., Reho A., Tasanen M., Vanhala J. Smart clothing prototype for the arctic environment, In: Personal and Ubiquitous Computing, 2002, vol. 6, pp. 3-16

[15] Şahin O., Kayacan O., Bulgun E. Y. Akıllı Giysilerde Sıcaklık Kontrolünün Elektronik Gerçeklemesi. In: Akıllı Sistemlerde Yenilikler ve Uygulamaları Sempozyumu - ASYU'2006, Symposium Book, Istanbul, 2006

[16] Senol Y., Akkan T., Bulgun Y. E., Kayacan O. Active T-shirt, In: International Journal of Clothing Science and Technology, 2011, vol. 23, no. 4, pp. 249-257

[17] Kaappa E., Halme A., Vanhala J. A textile integrated system extending the awareness of an electrician for dangerously high voltage, In: Abstract book of $5^{\text {th }}$ European Conference on Protective Clothing and NOKOBETEF 10 "Future of Protective Clothing: Intelligent or not", Valencia, Spain, 2012, p. 16

[18] Yilmaz M., Bulgun Y. E., Şenol Y., Akkan T. Designing smart garment for firefighters, In: Abstract book of $5^{\text {th }}$ European Conference on Protective Clothing and NOKOBETEF 10 "Future of Protective Clothing: Intelligent or not", Valencia, Spain, 2012, p. 71

[19] Bye E., Hakala L. Sailing apparel for women: A design development case study. In: International Textile and Apparel Association, 2005, vol. 23, no. 1, pp. 45-55

[20] Steinthal, A. Inflatable sailing jacket. 1969, US patent, patent no: 3441963

[21] Jackson M. A. Inflatable Buoyancy Oilskin Jacket. 1988, US patent, patent no: 4767371

[22] Kaynor M., Branning P., Nolan B. Competition Sailing Jacket. 1977, US patent, patent no: 4011824

[23] Pankopf B. Protective garment for water activities. 1987, US patent, patent no: 4710978

[24] Rehberg R.S. Sports emergency care: A team approach. Slack Incorporated, U.S.A., 2007, pp. 84-87

[25] Achten J., Jeukendrup A. E. Heart rate monitoring. In: Sports medicine, 2003, vol. 33, no. 7, pp. 517-538

[26] Kamal R. Embedded systems 2E. Tata McGrawhill Publishing, New Delhi, 2011, pp. 178

[27] Hofmann-Wellenhof B., Lichtenegger H., Collins J. Global positioning system: theory and practice, In: Springer Science and Business Media. 2012, pp. 4-5

[28] Mouly M., Pautet M. B. The GSM system for mobile communications, Telecom Publishing, 1992

Authors:

\section{SUKRAN KARA ${ }^{1}$ \\ SEVIL YESILPINAR ${ }^{1}$ \\ YAVUZ SENOL ${ }^{2}$ \\ TANER AKKAN ${ }^{3}$}

Dokuz Eylul University,

${ }^{1}$ Faculty of Engineering, Department of Textile Engineering, Tınaztepe Campus, 35397

${ }^{2}$ Department of Textile Engineering, Tınaztepe Campus, 35397, Buca, Izmir, Department of Electrical and Electronics Engineering, Tınaztepe Campus, 35397

${ }^{3}$ Izmir Vocational School, Department of Mechatronics, Buca, Izmir, Turkey

Buca, Izmir, Turkey

e-mail: sukran.kara@deu.edu.tr, sevil.yesilpinar@deu.edu.tr, yavuz.senol@deu.edu.tr, taner.akkan@deu.edu.tr

Corresponding author:

\section{SUKRAN KARA}

sukran.kara@deu.edu.tr

sukran.kara.deu@gmail.com 


\section{A backlighting method for accurate inspection of woven fabric density}

\section{REZUMAT - ABSTRACT}

\section{Metoda de iluminare pentru inspecția precisă a desimii țesăturilor}

Pentru a inspecta automat desimea țesăturilor cu fire vopsite, în acest articol este propusă o metodă eficientă de iluminare. Această metodă conține patru etape: achiziția imaginilor țesăturii, detectarea asimetriilor firelor, segmentarea pragului de imagine și proiecția imaginii binare. Este utilizat un sistem de achiziție a imaginii cu două lumini, reflectorizantă și de transmisie, în partea superioară și inferioară, iar imaginile reflectorizante și de transmisie ale aceleiași regiuni din țesătură sunt capturate prin reglarea condițiilor de iluminare. Unghiurile de înclinare ale firelor în imaginea de transmisie sunt obținute prin utilizarea transformatei Hough, pentru ca acestea să fie inspectate în imaginea de reflexie. Imaginea de transmisie a țesăturii este convertită în imagini binare prin algoritmul Otsu. Curbele de proiecție create din imaginea binară prin metoda de proiecție devin netede prin algoritmul de regresie ponderată la nivel local. Numărul de vârfuri din curba de proiecție este luat în calcul și este detectat numărul de fire, iar desimea este calculată cu precizie. Rezultatele experimentale au demonstrat că metoda propusă este eficientă pentru țesături, prin testarea a opt probe de tesături gri și colorate, cu diferite modele de legătură.

Cuvinte-cheie: desimea țesăturii, retroiluminare, curbă de proiecție, imagine de transmisie, regresie ponderată la nivel local

\section{A backlighting method for accurate inspection of woven fabric density}

To inspect the yarn-dyed fabric density automatically, an efficient backlighting method is proposed in this paper. This method consists of four steps: fabric image acquisition, yarn skew detection, image threshold segmentation and binary image projection. Firstly, it is utilized an imaging acquisition system with two reflective and transmission lights in its top and bottom placements, and the reflective and transmission images of the same region in the fabric are captured respectively by adjusting the illumination condition. Secondly, the skew angles of yarns in transmission image are obtained by using Hough transform to inspect them in reflective image. Then, the transmission fabric image is converted into binary image by Otsu algorithm. Finally, the projection curves produced from the binary image by the projection method are smoothed by the locally weighted regression algorithm. The number of peaks in the projection curve is counted and therefore the number of yarns is detected and the density is calculated precisely. The experimental results proved that the proposed method is effective for woven fabrics by testing eight grey and color fabric samples with different weave patterns.

Keywords: Woven fabric density, backlighting, projection curve, transmission image, locally weighted regression

\section{INTRODUCTION}

Warp and weft density are the basic structural parameters of woven fabric, and they are also the important indicators to evaluate the quality of fabric. The density is the number of yarns in a unit length. Traditional methods of measuring woven fabric density are mainly based on manual operations. These methods are not only time-consuming and lab-intensive, but also they cannot avoid careless mistakes committed by skillful workers. The detection results are often influenced by the mental and physical condition of the inspectors easily. With the rapidly development of computer technology, computer-aid inspection of yarn-dyed fabric density becomes more and more workable. Many scholars have made plenty of valuable studies on the fabric density inspection.

The reflective fabric image is usually captured and yarns are segmented by digital image processing. The yarn segmentation methods to detect the fabric density can be categorized into two main groups: frequency domain analysis-based and spatial domain analysis-based methods [1]. The former methods include Fourier transform-based and wavelet transform-based methods [2-9]. The later methods include Wiener filter method, median filter-based, gray projection, correlation coefficient-based and clustering analysis-based methods [10-15]. These methods can recognize the densities of the solid color and grey fabric with great accuracy, but the yarn-dyed fabrics with some misjudgments. In the yarn-dyed fabric image, the color signals play a dominant role and the intensity signals decreasing from the yarn center to the interstices play an inferior role. Additionally long hairiness on the fabric surface has a negative influence on the yarn segmentation result. It is difficult to locate yarns of yarn-dyed fabric by these methods with a high accuracy [15-16].

Therefore, we propose an Otsu algorithm-based projection method to inspect the woven fabric density automatically, including grey, solid color and yarndyed fabrics. We take full advantage of the light 
transmittance of woven fabric to reduce the difficulty to detect the fabric density. A new optical system is used to capture the reflective and transmittance images of yarn-dyed fabrics, and the Otsu algorithmbased projection method is applied to segment the yarns of the transmittance image.

\section{EXPERIMENTAL WORK}

\section{Fabric image acquisition}

An optical system of SMZ 140-N2LED is used to capture a reflective color fabric image in the RGB mode, as shown in figure 1 . The resolution is set at 6.5359 um/pixel $\times 6.4516$ um/pixel along the $X$ and $Y$ coordination. In figure 1 , there are two light-emitting diode (LED) lights in the top and bottom placements to adjust the illumination condition: reflective and transmission lights. Each LED light has two states: $\mathrm{NO}$ and OFF. There is a light intensity controller that can adjust the illumination intensity of the LED lights simultaneously. The experiments of the method are carried out with MATLAB 2013a. The computer doing experiments is equipped with the Win7 Ultimate System, CPU Intel(R) Core(TM) i3 and 2.00 GB memory.

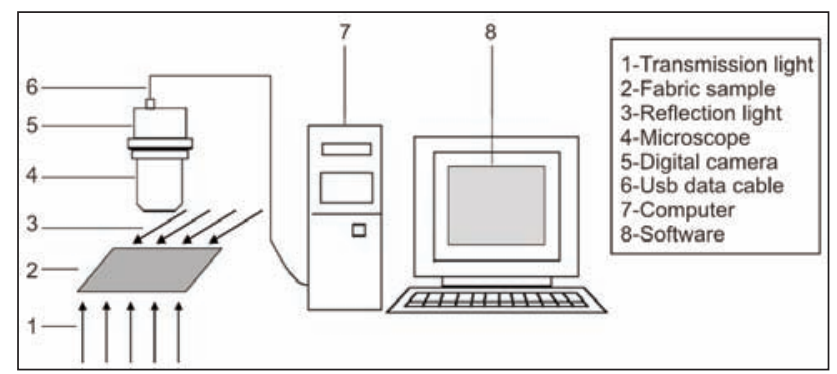

Fig. 1. The imaging acquisition system

The fabric sample is placed above the bottom LED light when capturing image. To reduce the color differentiation on the fabric's appearance, the capture region is chosen far from the edge, and the surface of fabric should be clearly visible. Utilizing the light transmittance of woven fabric, the reflective and transmission images of the same region in the fabric are captured respectively. The reflective image of fabric is captured when the bottom transmitted light is
OFF and the top reflection light is ON, as shown in figure 2, a. The corresponding transmission image is captured when the bottom transmitted light is $\mathrm{ON}$ and the top reflection light is OFF, as shown in figure $2, b$. In the experiments, the reflective and transmittance images of the same fabric Sample 0 in figure 2 are captured to validate the effect of the method. The image size is 1536 pixels $\times 1618$ pixels. Compared with the reflective fabric image, the transmission image has clearer yarn clearances, which reduce the difficulty of yarn segmentation significantly.

\section{Yarn skew detection}

Because of the fabric placement, the slant of fabric cannot be avoided. The slant of fabric can affect the yarn segmentation results greatly. To realize the precise measurement of fabric density, the skew angles of the warp and weft yarns in reflective image are detected by the Hough transform [17-18].

To save computation time, the color fabric image is converted into gray image. The gray fabric image is underwent the threshold process to remove most of the pixels, leaving just some which represent the locations of interstices in the fabric image. When the fabric image is segmented by the threshold $t_{0}$ $\left(t_{0}=\max (G) \times 0.995\right)$, the fabric image in figure $2, b$ is converted into binary format, as shown in figure 3 , $a$. To detect the skew angles of weft and warp yarns, the Hough transform is applied to white pixels in figure $3, a$. The essence of the Hough transform is to change all the pixels in the image from $X$ and $Y$ coordinates $(x, y)$ to polar coordinates $(s, \theta)$ as in

$$
s=x \cdot \cos \theta+y \cdot \sin \theta
$$

where $\theta$ with the highest frequency is regarded as the skew angle of the yarns [17, 18]. The angle distribution map of figure $3, a$ is shown in figure $3, b$. In figure $3, b$, the green squares represent the skew with the highest frequency in the Top 20. The skew angle is considered to be no more than $20^{\circ}$. The skew of weft yarns, $\theta_{\text {wefts }}$, is set within the range $\left[80^{\circ}, 100^{\circ}\right]$. The skew of warp yarns, $\theta_{\text {warps }}$, is set within the ranges $\left[0^{\circ}, 10^{\circ}\right]$ and $\left[170^{\circ}, 180^{\circ}\right]$. The skew angles of warps and wefts are detected in figure $3, b$ : $\Delta \theta_{\text {warps }}=0.17^{\circ}, \Delta \theta_{\text {wefts }}=0^{\circ}$.

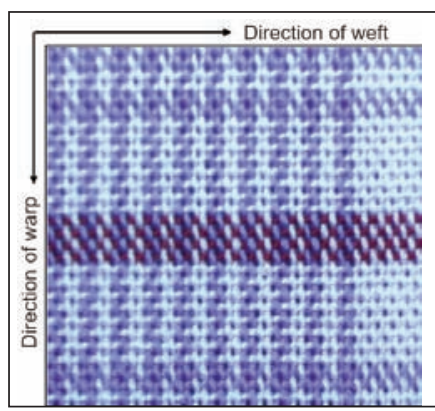

a

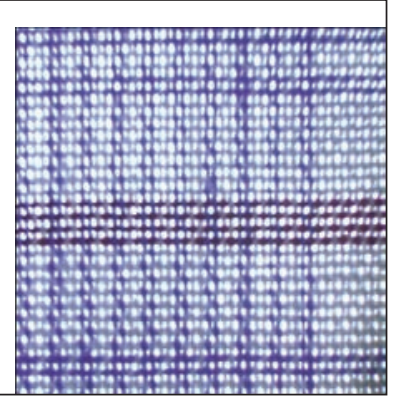

$\boldsymbol{b}$

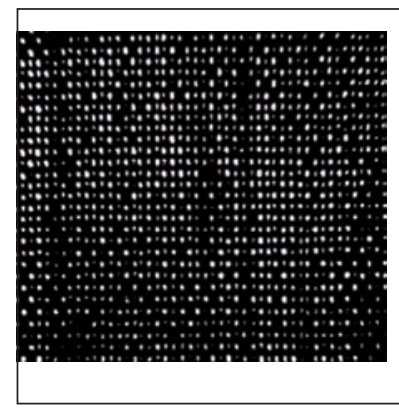

a

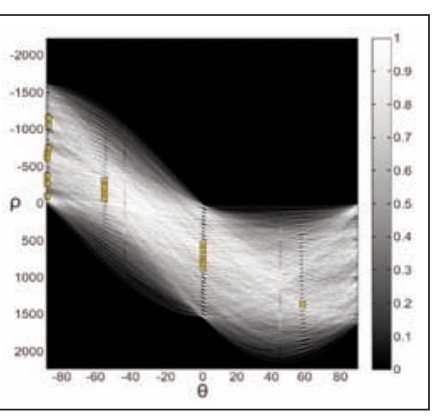

$\boldsymbol{b}$

Fig. 2. Image of yarn-dyed fabric sample 0: $a-$ the reflective image; $b$ - the transmission image

Fig. 3. Yarn skew detection: $a$ - the binary format; $b$ - the angle distribution map 


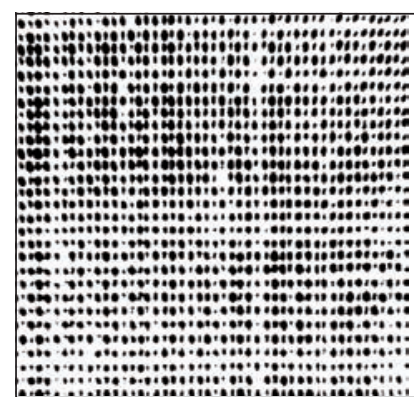

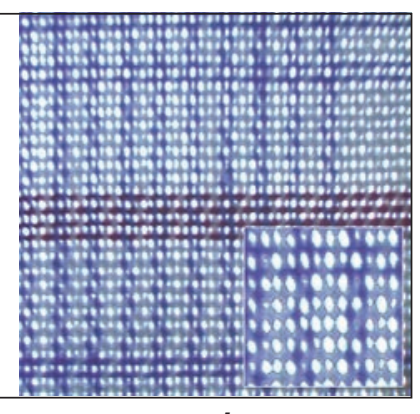

b
Fig. 4. Image threshold segmentation result: a - binary image; $b$-transmission image with interstice contours

\section{Image threshold segmentation}

To detect the yarn locations, the transmission image in figure $2, b$ is converted into gray image, successively changed into binary format by Otsu algorithm, and the binary image is projected in row and column respectively. In Otsu algorithm [19], the image is divided into foreground and background at a threshold $t$. The optimum $t$ is one that maximizes the interclass variance $\sigma_{\mathrm{w}}^{2}(t)$ :

$$
\sigma_{w}^{2}(t)=w_{1}(t) \times w_{2}(t) \times\left[u_{1}(t)-u_{2}(t)\right]^{2}
$$

where $w$ are the probabilities of the two classes separated by the threshold $t, u$ are the class means. The binary image of the transmittance image is shown in figure 4, a. In figure 4, the white pixels represent the position of yarns and $V_{i, j}=1$, the black pixels represent the position of interstices and $V_{i, j}=0$, where $V$ is the binary matrix of the fabric image whose size is $N \times M, i=1,2, \ldots, M, j=1,2, \ldots, N$. Figure $4, b$ shows the transmission image with the inspected interstice contours.

\section{Binary image projection}

Because the inspection of the warp density is more difficult than that of weft density, we focus on explanation of the experiments for warp density detection. To obtain the projection curves of the fabric image in figure 4 , the values are accumulated in each column respectively.

$$
V_{j}^{\prime}=\frac{1}{M} \sum_{i=1}^{M} V_{i, j}
$$

where $V_{i, j}$ is the value of the pixels in the fabric image, $i=1,2, \ldots, M, j=1,2, \ldots, N$. The projection curve is obtained, as shown in figure $5, a$.

Taking the noise points in the projection curves into consideration, the projection curves should be smoothed by the locally weighted regression (LOESS) algorithm [20-22]. In the smoothed projection curve, the peaks correspond to the yarn centermain lines and the valleys correspond to the interstices between yarns. We obtained the rough number of the warps by counting the peaks in the projection curve using the following steps:

Step 1: The peaks of the original projection curve are counted. If $V_{j}^{\prime}-V_{j+1}^{\prime} \geq 0$ and $V_{j}^{\prime}-V_{j-1}^{\prime} \geq 0, J_{0}=J_{0}+1$,
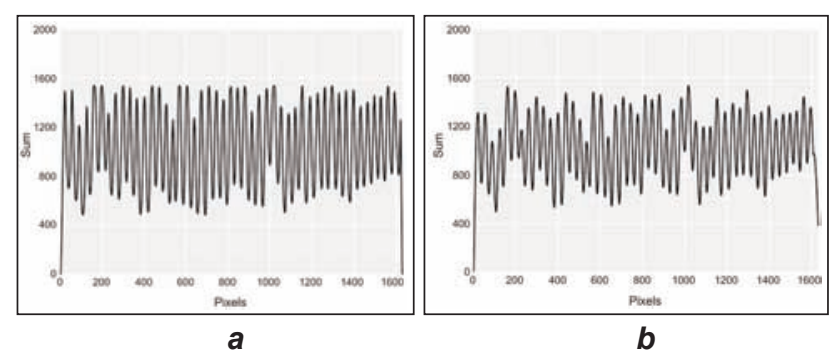

Fig. 5. The projection curve corresponding to the warp yarns: $a$ - before smoothing; $b$ - after smoothing
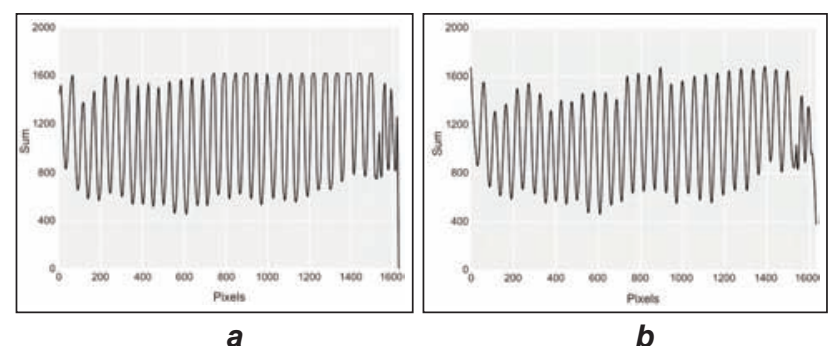

Fig. 6. The projection curve corresponding to the weft yarns after smoothing: $a$ - Before smoothing; $b$ - after smoothing

where $J_{0}$ is the roughly estimated number of the warps and its original value is 0 .

Step 2: The peaks of the projection curve after smoothing are counted to confirm the precise smoothing span. The span $\left(S_{1}\right)$ of LOESS algorithm is set as $\gamma_{1} \times N / J_{0}$. In the beginning of the experiment, the value $\gamma_{1}$ is set as 2 . The proper proportionality constant $\gamma_{1}$ will be analyzed and discussed in the third section. After that, the smoothed projection curve $V^{\prime \prime}$ is obtained from the original projection curve $V^{\prime}$. If $V_{j}^{\prime \prime}-V_{j+1}^{\prime \prime} \geq 0$ and $V_{j}^{\prime \prime}-V_{j-1}^{\prime \prime} \geq 0, J_{1}=J_{1}+1$, where $J_{1}$ is the roughly estimated number of the warps and its original value is 0 .

Step 3: The peaks of the projection curve after smoothing are counted to acquire the precise number of the warps. The span $\left(S_{2}\right)$ of LOESS algorithm is set as $\gamma_{2} \times N / J_{1}$. In the beginning of the experiment, the value $\gamma_{2}$ is set as 1 . The proper proportionality constant $\gamma_{2}$ will be analyzed and discussed in the third section. After that, the smoothed projection curve $V^{\prime \prime \prime}$ is obtained from the original projection curve $V^{\prime}$. If $V_{j}^{\prime \prime \prime}-V_{j+1}^{\prime \prime \prime} \geq 0$ and $V_{j}^{\prime \prime \prime}-V_{j-1}^{\prime \prime \prime} \geq 0, J_{2}=J_{2}+1$, where $J_{2}$ is the precise number of the warps and its original value is 0 .

The final smoothed projection curve $V^{\prime \prime \prime}$ is shown in figure $5, b$. To inspect the precise number of the wefts, we rotate the fabric image by $90^{\circ}$ and use the above steps to conduct the fabric image and obtain the final smoothed projection curve, as shown in figure 6. According to the smoothed projection curve, the precise number of the wefts $W_{2}$ is counted. After that, the yarn segmentation results of the fabric image in figure 2 are shown in figure 7 . In figure 7 , the weft and warp yarns are both segmented without any misjudgments. 


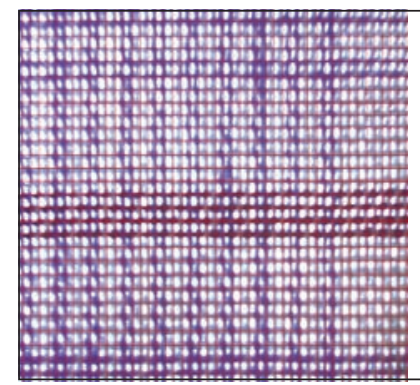

a

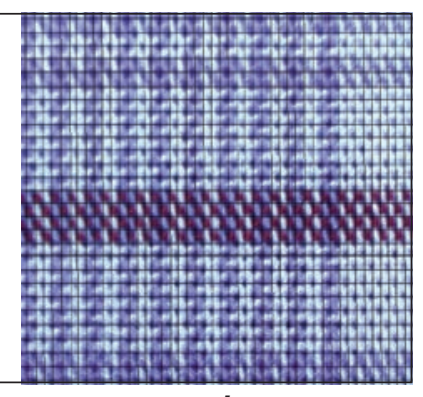

b

Fig. 7. Yarn segmentation of yarn-dyed fabric sample 0: $a$ - the reflective image; $b$ - the transmittance image

\section{RESULTS AND DISCUSSIONS}

In the above experiments, the yarn-dyed fabric in figure 2 has been conducted. In this section, another seven fabric samples are used to illustrate the effectiveness of the automatic method and compare the fabric density errors inspected by the automatic method and the manual method. Finally, parameters of the automatic method have been analyzed and discussed, and the optimal parameters have been obtained.

\section{Yarn segmentation experiments}

Before the test, the span of the data smoothing $(S=\gamma \times N / J)$ should be set, $\gamma_{1}$ is set as $1, \gamma_{2}$ is set as

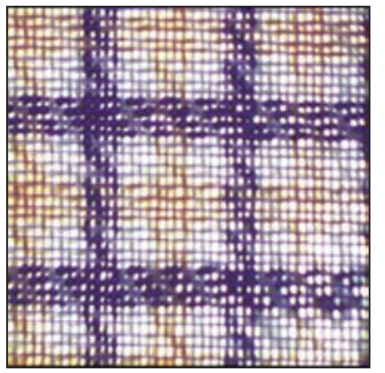

a1

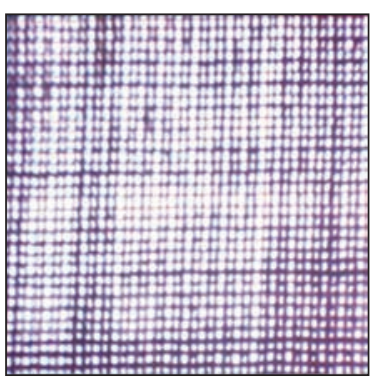

c1

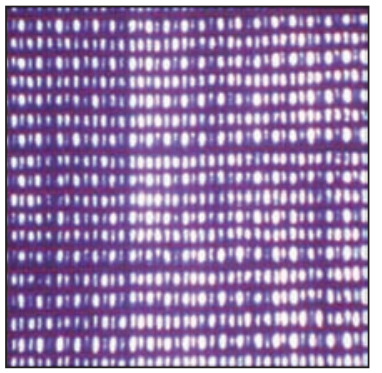

e1

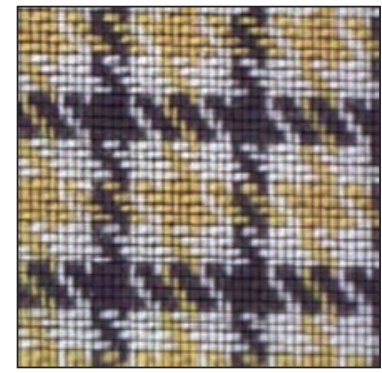

a2

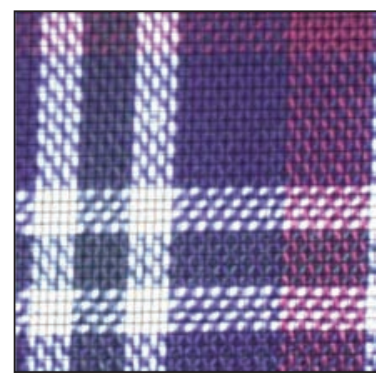

$c 2$

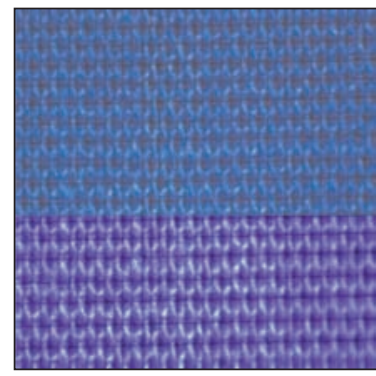

e2

1. The yarn segmentation results of the 7 fabric samples are shown in figure 8 . In figure 8 , Sample 1 is a $2 / 2$ twill yarn-dyed fabric, Sample 2, 3 and 4 are plain yarn-dyed fabrics, Sample 5 is a solid color plain fabric, Sample 6 is a grey 2/1 twill fabric, the warp and weft yarns of all samples are segmented successfully without any misjudgments. Hence, the Otsu algorithm-based projection method can inspect the yarndyed fabric density correctly. To illustrate the precision degree of the automatic method, the fabric density inspected by the automatic method is compared to that by the manual method, as shown in table 1, The specific formula of error is shown as the following:

$$
\text { error }=\left|x-x^{\prime}\right| / x \times 100 \%
$$

where $x$ is the density measured manually, $x^{\prime}$ is the density measured automatically.

In table 1, the Sample 1 and 4 yield the largest detection error, whose weft density errors are $0.12 \%$ and $0.14 \%$ respectively. Basically, in the experiment, the units of the automatic and manual methods are yarn and pixel respectively, and the corresponding lengths of the measured regions are $2.54 \mathrm{~cm}$ and $1.68 \mathrm{~cm}$ (the physical size of the fabric image) respectively. From the perspective of single measurement, the manual method is better than the automatic

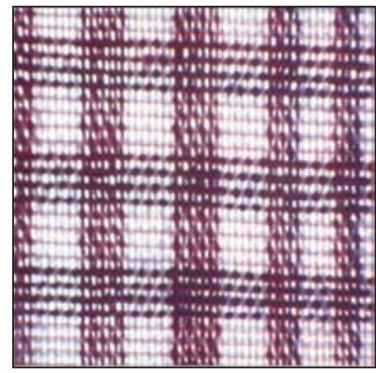

b1

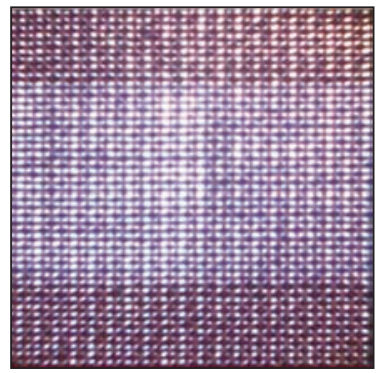

d1

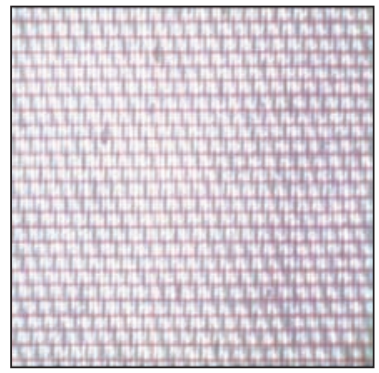

f1

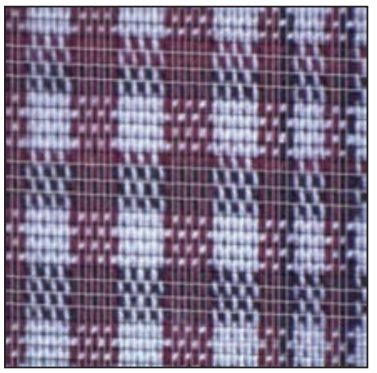

b2

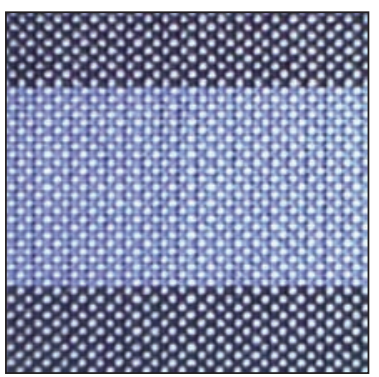

d2

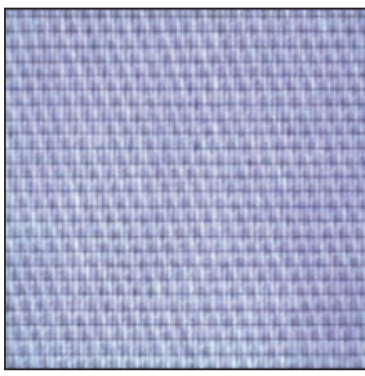

f2

Fig. 8. Yarn segmentation results of different fabrics: a1, a2, a3, a4, a5 and a6 - transmittance images of Sample 1-6; b1, b2, b3, b4, b5 and $b 6$ - reflective images of Sample 1-6

industroia textilă 
WARP AND WEFT DENSITY OF MANUAL AND AUTOMATIC MEASUREMENT

\begin{tabular}{|c|c|c|c|c|c|c|}
\hline \multirow{3}{*}{ Sample } & \multicolumn{6}{|c|}{ WARP AND WEFT DENSITY OF MANUAL AND AUTOMATIC MEASUREMENT } \\
\hline & \multicolumn{2}{|c|}{ Warp density (thds $/ 10 \mathrm{~cm}$ ) } & \multicolumn{2}{|c|}{ Weft density (thds/10 cm) } & \multicolumn{2}{|c|}{ Error (\%) } \\
\hline & Automatically & Manually & Automatically & Manually & Warp & Weft \\
\hline 1 & 269.7 & 269.5 & 242.2 & 242.5 & 0.07 & 0.12 \\
\hline 2 & 288.2 & 288.0 & 187.4 & 187.5 & 0.07 & 0.05 \\
\hline 3 & 286.1 & 286.0 & 248.4 & 248.5 & 0.03 & 0.04 \\
\hline 4 & 302.7 & 302.5 & 194.2 & 194.5 & 0.07 & 0.14 \\
\hline 5 & 298.8 & 299.0 & 181.6 & 181.5 & 0.06 & 0.07 \\
\hline 6 & 352.2 & 352.0 & 242.2 & 242.0 & 0.05 & 0.08 \\
\hline
\end{tabular}

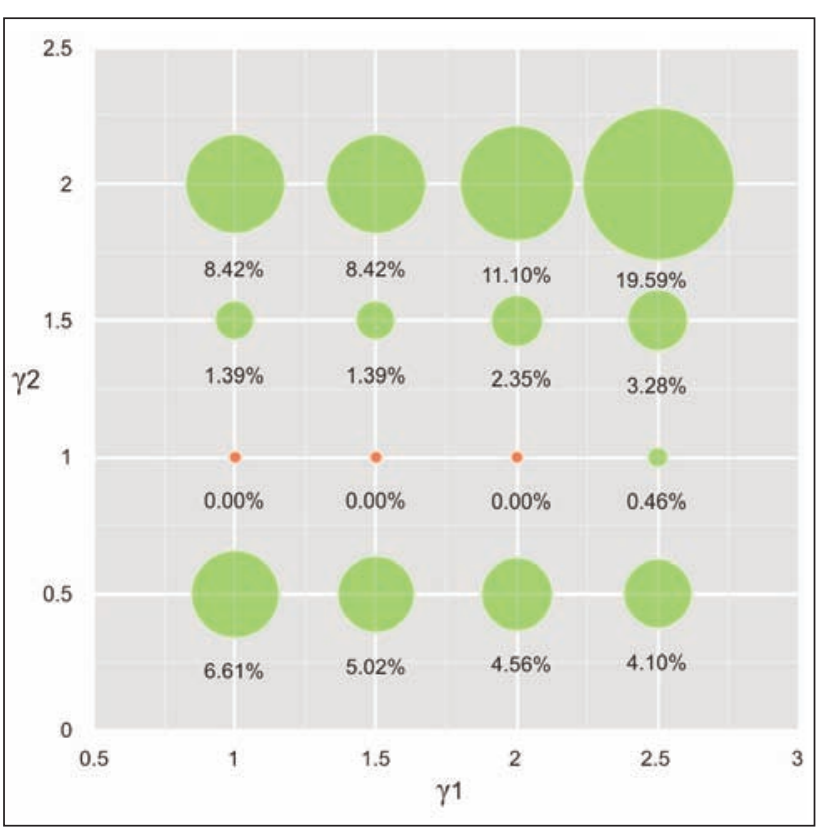

Fig. 9. The average error of sample 2 and 3 by different parameters

method, because of the bigger measured regions. Nonetheless, the opposite situation has happened after the multiple measurements, because the measured times of the automatic method is greater so that the sum of measured regions is lager and the value of fabric density is more stable. Hence, it demonstrates that the proposed method is more reliable and more accurate after multiple measurements. Overall, the error of the fabric density inspected by the automatic method is below $0.14 \%$ in table 1 . Therefore, our automatic method can take place of the manual method to inspect the fabric density in physical production.

\section{Process control parameters selection}

The method in this paper is based on LOESS algorithm to smooth data. The span of LOESS algorithm $(S=\gamma \times N / J)$ is determined by $\gamma$. The parameter, $\gamma_{1}$ and $\gamma_{2}$, exercise a great influence on the precise inspection of the fabric density. It is necessary to analyze the effects on the fabric density measurement by different parameters. Yarn-dyed fabrics of Sample 2 and 3, have been used to test the fabric density errors by different $\gamma_{1}$ and $\gamma_{2}$, as shown in figure 9 .

In figure 9, the average error is the mean value of warp and weft errors of sample 2 and 3 . The size of the bubble represents the average error in corresponding $\gamma_{1}$ and $\gamma_{2}$. When $\gamma_{2}=1$, the average error is small, especially, when $\gamma_{1} \in[1,2]$, the average error is $0.00 \%$. Therefore, in the experiments, $\gamma_{2}=1$ and $\gamma_{1} \in[1,2]$ can give an optimal yarn segmentation result.

\section{CONCLUSIONS}

In the paper, a backlighting-based method is proposed to inspect the yarn-dyed fabric density automatically. An imaging acquisition system with two reflective and transmission lights in its top and bottom placements, is used to capture the reflective and transmission images of the same region in the fabric respectively by adjusting the illumination condition. The transmission fabric image is corrected, thresholded and projected successively. Subsequently, the projection curves are smoothed by the locally weighted regression algorithm, whose peaks are counted to calculate the fabric densities.

The greatest creativeness in the paper is the fabric image acquisition approach that is to capture the reflective and transmission images simultaneously. The light transmittance of woven fabric is exploited sufficiently. The transmission fabric image makes the automatic inspection of fabric density more efficient and accurate. It can realize the automatic inspection of density for grey and yarn-dyed fabrics with different woven structures.

\section{Acknowledgments}

The authors would like to acknowledge the National Natural Science Foundation of China (No. 61202310); Research Fund for the Doctoral Program of Higher Education of China(20120093130001); the Henry Fok Educational Foundation (141071); the National Postdoctoral Fund Project (2013M541602); the Postdoctoral Fund Project of Jiangsu Province (1301075C); Prospective Industry University Research Project of Jiangsu Province (BY2013015-20); the Postgraduate Research Project of Jiangsu Province (KYLX15_1180). 


\section{BIBLIOGRAPHY}

[1] Jie Zhang, Binjie Xin, Xiangji Wu. A review of fabric identification based on image analysis technology, In: Textiles and Light Industrial Science and Technology 2013, 2(3), pp. 120-130.

[2] Weidong Gao, Jihong Liu, Bojun Xu, Wei Di, Wei Xue, Automatic identification of weft arrangement parameters in fabric, In: Cotton Textile Technology 2002, 30(3), pp. 31-34.

[3] Binjie Xin, Xufen Yu, Zhaoping Wu, Automatic measurement of the yarn density of woven fabric, In: Journal of China Textile University 1999, 25(3), pp.34-36.

[4] Jinjeong Young and Hojang Jin, Applying image analysis to automatic inspection of fabric density for woven fabrics, In: Fibers and Polymers 2005, 6(2), pp. 156-161.

[5] S. A. Hosseini Ravandi, K. Toriumi, Fourier transform analysis of plain weave fabric appearance, In: Textile Research Journal 1995, 65(11), pp. 676-683.

[6] Bugao Xu., Identifying fabric structures with fast Fourier transform techniques, In: Textile Research Journal 1996, 66(6), pp. 496-506.

[7] Maroš Tunák, Aleš Linka, Petr Volf, Automatic assessing and monitoring of weaving density, In: Fibers and Polymers 2010, 10(6), pp. 830-836.

[8] Yili Feng, Ruqin Li, Automatic measurement of weave count with wavelet transfer, In: Journal of Textile Research 2001, 22(2), pp. 30-31.

[9] Xunming Zhao, Zhongmin Dend, Youting Ran, The automatic detection technology of woven fabric density based on wavelet transform, In: Progress in Textile Science and Technology 2011; (5), pp. 45-47.

[10] Weidong Gao, Jihong Liu, Bojun Xu, Wei Di, Wei Xue, Automatic identification of warps arrangement parameters in fabric, In: Cotton Textile Technology 2002, 30(3), pp. 31-34.

[11] Ruru Pan, Weidong Gao, Jihong Liu, Automatic inspection of solid color fabric density by Hough transforms, In: Fibres and Textiles 2010, 18(4), pp. 46-51.

[12] Ruru Pan, Weidong Gao, High-precision identification of woven fabric density via image process, In: Journal of Textile Research 2008, 29(11), pp. 128-131.

[13] Ruru Pan, Jihong Liu and Weidong Gao, Measuring linear density of threads in single-system-mélange color fabrics with FCM algorithm, In: Color Research and Application 2013, 38(6), pp. 456-462.

[14] Ruru Pan, Weidong Gao, Jihong Liu, Automatic inspection of double-system-mélange yarn-dyed fabric density with color-gradient image, In: Fibers and Polymers 2011; 12(1), pp.127-131.

[15] Lenka Techniková, Maroš Tunák, Weaving density evaluation with the aid of image analysis, In: Fibres and Textiles 2013, 2(98), pp. 74-79.

[16] Ruru Pan, Weidong Gao, Jihong Liu, Skew rectification for yarn-dyed fabric via FFT in HSL color space, Software Engineerin, In: WRI World Congress on 2009; 2, pp. 481-485.

[17] P. V. C. Hough, 1962, Methods and means for recognizing complex patterns, In: U.S. Patent 3,069,654.

[18] J. Llingworth, J. Kittler, A survey of the Hough transform. Computer Vision, In: Graphics and Image Processing 1988, 44, pp. 87-116.

[19] N. Otsu, A threshold selection method from gray-level histograms, In: IEEE trans. on system, man, cybernetics 1979, 9(1), pp. 62-66.

[20] Cleveland, S. William, Robust locally weighted regression and smoothing scatterplots, In: Journal of the American Statistical Association 1979, 74(368), pp. 829-836.

[21] Cleveland, S. William, LOWESS: a program for smoothing scatterplots by robust locally weighted regression. In: The American Statistician 1981, 35(1), p. 54.

[22] Cleveland, S. William, Devlin, Locally-weighted regression: an approach to regression analysis by local fitting, In: Journal of the American Statistical Association 1988, 83(403), pp. 596-610

\section{Authors:}

\section{JIE ZHANG}

RURU PAN

WEIDONG GAO

Key Laboratory of Eco-textiles, Ministry of Education, School of Textile and Clothing Jiangnan University, Wuxi, China

email: peterzhang19911130@gmail.com, prrsw@163.com, gaowd3@163.com

Corresponding author:

RURU PAN

prrsw@163.com 


\section{General behavior and parameters affecting the Ink jet printing phenomenon on woven polyester fabric}

\section{REZUMAT - ABSTRACT}

\section{Comportamentul general şi parametrii care afectează fenomenul de imprimare cu jet de cerneală pe țesătura de poliester}

Studiul higroscopicității textilelor are implicații importante în industria textilă și in industria prelucrării hârtiei, cum ar fi capacitatea de spălare, procedurile chimice și de selecție a tehnologiilor inginerești moderne, precum imprimarea cu jet de cerneală. Lucrarea de față își propune să studieze efectul diferiților parametri ai lichidelor şi structurii țesăturii asupra impactului picăturii de lichid, prin experimente. Digidrop cu camera de înaltă rezoluție este utilizat pentru a măsura diferiți parametri ce caracterizează acest fenomen. Rezultatele obținute arată că proiecția înaltă a picăturii afectează profund profilul picăturii și comportamentul de răspândire după deformarea importantă a picăturii la impactul pe suprafață. Structura țesăturii, cum ar fi numărul firelor de bătătură și natura fibrei, influențează impactul picăturii. Pentru legătura pânză, o creștere a numărului de fire de bătătură determină o scădere a ratei de penetrare și o creștere a ratei de răspândire. În final, tensiunea superficială a picăturii de lichid folosit influențează comportamentul general al fenomenului de umezire.

Cuvinte-cheie: unghi de contact, umezire, răspândire statică, răspândire dinamică, impactul picăturii, țesătură

\section{General behavior and parameters affecting the Ink jet printing phenomenon on woven polyester fabric}

Studying textile wettability has important implications in textile industries and paper treatment as the detergency, the chemistry and material-selection procedures of modern engineering materials, such as ink jet printing. This present paper aims to study the effect of different parameters of liquid, fabric structure and experiment on the liquid drop impact. The digidrop with high resolution camera is used to measure the different parameters characterizing this phenomenon. The obtained results show that the high drop projection affects deeply the drop profile and the spreading behavior after important drop deformation at the surface impact. Then, the fabric construction as the weft count and the nature of fiber influence the drop impact. For the plain weave, an increase of weft count causes a decrease of penetration and increase the spreading rate. Finally, the surface tension of used liquid drop influences the general behavior of wetting phenomenon.

Keywords: contact angle, wetting, static spreading, dynamic spreading, drop impact, woven fabric

\section{INTRODUCTION}

The wetting of solid surfaces by liquids is a central process in many practical applications, such as printing, painting, adhesion, lubrication and spraying on surfaces [1-4]. The most common forms of wetting are spreading of the drop on a solid surface and the penetration of liquids into capillary pores. Drop spreading is one of the most studied wetting processes from a fundamental point of view. This phenomenon is characterized by the contact angle which determinates the surface hydrophobicity and permit to calculate the solid surface tensions [5, 6]. Many techniques can be used to measure the contact angle which based on Thomas Young's equation [7-9]. Young's equation (1) explains the equilibrium of the three interfacial tensions:

$$
\cos \theta=\frac{\gamma_{S V}-\gamma_{S L}}{\gamma_{L V}}
$$

Where the variable $\gamma$ refers to interfacial tension of the solid-liquid (sl), solid-vapor (sv) and solid-liquid interfaces (sl).
The Young's equation assumes that the solid surface is smooth, homogeneous and rigid and should also be chemically and physically inert (figure 1). In a real system, it is known that wetting phenomenon is affected by surface properties. Wenzel proposed a theoretical model describing the contact angle $\theta^{*}$ at a rough surface [10]. He modified Young's equation as follows:

$$
\cos \theta^{*}=r \cos \theta
$$

Therefore, there is a range of contact angles between two extremes. The highest value of the

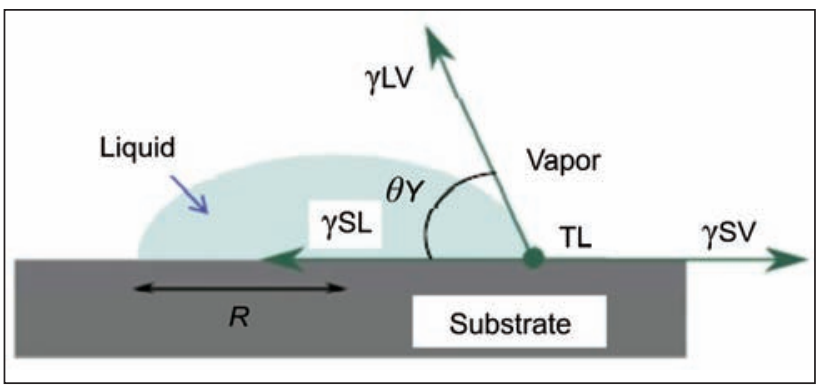

Fig. 1. Contact angle and the three interfacial tensions 
range is the advancing contact angle. The lowest value is the receding contact angle. The difference between the advancing and receding contact angles is known as the contact angle hysteresis. The contact angle hysteresis has been studied extensively and its causes and its origins are not completely understood. The roughness and the heterogeneity and the surface energetic are the most reason of the hysteresis [11-17]. More recent studies, confirmed the others first studies on the contact angle hysteresis [18-21]. Two wetting regimes can be distinguished the static phenomenon where the deposit of the drop is without outside strength or kinetic energy and the dynamic phenomenon in which the drop was projected reflecting the ink jet printing technique. The static phenomenon was widely studied and many parameters characterizing the liquid - surfaces interactions were invented by Gillespie [22]. These most important parameters of this first regime are the contact angle, drop diameter, the height and the volume. The ray of the contact drop-substrate is given by the equation (3):

$$
R(t)=R_{i}\left[1+\left(\frac{4(n+1) \alpha \gamma k_{s}}{n \eta R_{i}^{2} e}\right) t\right]^{\frac{1}{2(n+1)}}
$$

Where $e$ is thickness of the substrate, $R_{i}$ - initial ray, $k_{s}$ - permeability of the porous material, $\alpha$ and $n-$ constants.

Then Kissa [23] used the Gillespie [22] equation, which predicts the dependence of drop ray at the time, to measure the liquid drop area as given by the following relation (4):

$$
A=K\left(\frac{\gamma}{\eta}\right)^{u} V^{m} t^{n}
$$

$K$ is the capillary sorption coefficient, $u, m$ and $n$ are constants, $V$ is the volume of the drop liquid.

The Volume $V(t)$ of the drop is assimilated to a spherical cap, it is calculated from the diameters $D(t)$ and the drop height $h(t)$ according to the following equation:

$$
V(t)=\frac{\pi h(t)}{t}\left[3\left(\frac{D(t)}{2}\right)^{2}+h^{2} t\right]
$$

The drop impact or dynamic spreading on solid substrate goes back up to 1966 . However, the first real study was studied by Leidenfrost [24]. It has been shown that the dynamic and thermal features of this impact were influenced by many parameters. The interface interactions depend on liquid phase and surface properties. This phenomenon results in three outcomes: bouncing, spreading, or splashing. Many factors characterizing the liquid drop impact on a solid substrate phenomenon exist in literature and the most important are the Weber number which corresponds to the report between the inertial forces and superficial tension of the drop, the Reynolds number which defines the report between the inertial forces and the viscous forces. These parameters were given respectively by the following equations (6) and (7):

$$
\begin{aligned}
& W e_{n}=\frac{\rho_{l} V_{i, n}^{2} D_{0}}{\sigma_{l}} \\
& R e_{n}=\frac{\rho_{l} V_{i, n} D_{0}}{\mu_{l}}
\end{aligned}
$$

Where $V_{i, n}, D_{0}$ and $\rho_{l}, \sigma_{l}$ are respectively the incidental normal speed of the drop, the diameter, the density of the liquid and the superficial tension of the liquid. For both wetting regimes on textile woven fabric, the literature shows several works being interested in the survey of the impregnation and the spreading of liquid on porous material [25-28]. Therefore, the surface tension, the gravitational forces and viscous forces govern the spreading and penetration of liquid over a porous substrate [29]. Then, this phenomenon is directly relied to liquid and fiber characteristics [30]. Thus, several researches showed the fabrics characteristics effect on spreading, impregnation and diffusion phenomena [31-34].

In this case, much progress in wetting is invented thanks to improvements in contact angle measurements techniques. But, such questions of drop spreading have not yet been answered such the general behavior of the drop wetting on the anisotropic material as textile fabric. This state is very considered in the case of the textile inkjet printing where an overlap of the contour colors is observed. In addition, there is a need for more experimental data for the kinetics of partial wetting of drops on textile material. Therefore, the objectives of this paper are: (a) to present the general behavior of static and dynamic of the drop on textile fabric was investigated. (b), we will look at the effect of the projection distance of the drop on the virgin glass and on the fabric. Therefore, the effect of the surface tension on the textile fabric is investigated. Then, the effect of the support parameters on the impact and spreading was studied.

\section{EXPERIMENTAL WORK}

In order to study the phenomenon of static and dynamic wetting, homogenous material and ideal surface were prepared. The used surface is the glass plate. It has been cleaned to the ultrasonic sounds during 30 seconds in ethanol solution, then rinsed with the same solvent and dried to nitrogen. Then the surface is treated and activated in an oxidizing solution "Piranha" in $50^{\circ} \mathrm{C}$ during 30 min (mixture of 3 vol. of $30 \% \mathrm{H}_{2} \mathrm{O}_{2}$ and 7 vol. $\mathrm{H}_{2} \mathrm{SO}_{4}$ ). After this treatment the glass plate is rinsed with twice distilled water and then dried under flux of nitrogen.

The dispersive coating paste has been taken from an industrial society specialized in ink-jet printing of which its formulation is shown in table 1.

The weaving structure is $100 \%$ polyester plain weave; the warp count was 22 per $\mathrm{cm}$ and the weft count was varied; 11,17 and 22 per $\mathrm{cm}$. As to treat woven fabric, first the reverse-rollers coating technique 


\begin{tabular}{|l|c|}
\hline \multicolumn{2}{|c|}{ Dispersive paste } \\
\hline Setaprint RST-A & $4 \%$ \\
\hline Setaprint NDG & $1.5 \%$ \\
\hline Urea & $15 \%$ \\
\hline Sodium Bicarbonate & $2.5 \%$ \\
\hline
\end{tabular}

was used to apply the dispersive coating paste on fabric. Then, to study the effect of drying process of the coating agents, the treated woven fabric was at the ambient drying conditions $\left(25^{\circ} \mathrm{C}\right)$ and the oven drying (industrial scale) $110^{\circ} \mathrm{C}$ for 2 minutes in oven room.

The kinetic spreading parameters were studied using water $\left(72.1 \mathrm{mN} \times \mathrm{m}^{-1}\right)$ and ink $\left(45 \mathrm{mN} \times \mathrm{m}^{-1}\right)$ droplets. The evolution of drop profile was captured with videocamera of GBX Digidrop (figure 2) with 25 captures per second. The liquid volume was $5 \mu \mathrm{l}$ and every measure was repeated 3 times.

\section{RESULTS}

\section{The static and dynamic wetting regime}

In this paragraph, behaviors of static and dynamic wetting are investigated. The static regime was done by the drop sessile technique. The dynamic regime was done by free fall of the drop on the wanted surface. The used drop was the ink solution having a $5 \mu$ as drop size. These applied conditions permit to approach of the case of the ink jet printing process. The static wetting regime presents two different phases along this phenomenon. The first is at short time, which characterized by the coexistence of the spreading. This phenomenon controls the drop profile at these first instants. The drop spreads on the solid to reach its maximum as shown in the figure 3 . It has important diameter and high variation from the first impact (0 ms to $40 \mathrm{~ms}$ ). Then, figure 4 demonstrates that contact angle variation show

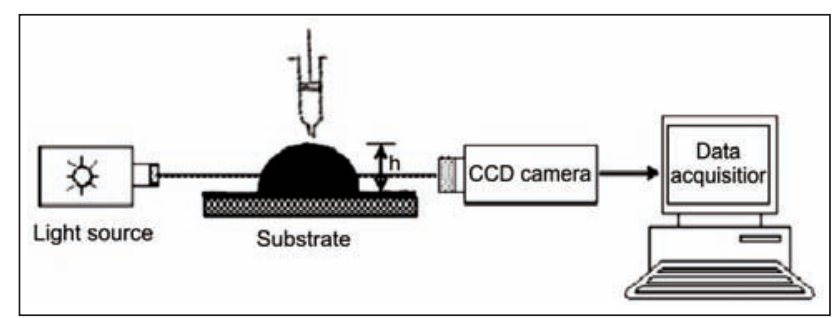

Fig. 2. The experimental set up of spreading parameters

the two phases and the significant decrease in the first instants of static wetting regime. In the second phase (long times) the drop diameter reach its maximal spreading and stabilized. Therefore, the evaporation controls the profile of the drop during this running.

Generally, for the static wetting regime, the spreading phenomenon was observed for first instants for both

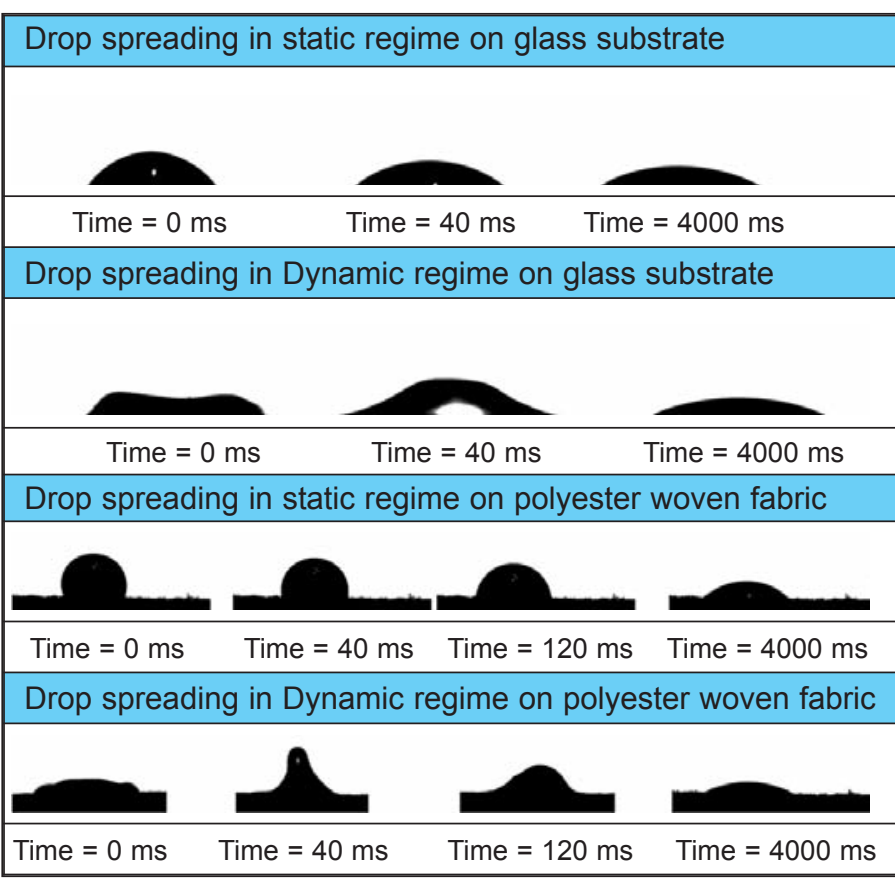

Fig. 3. Drop deformation as function of the wetting regime and used material
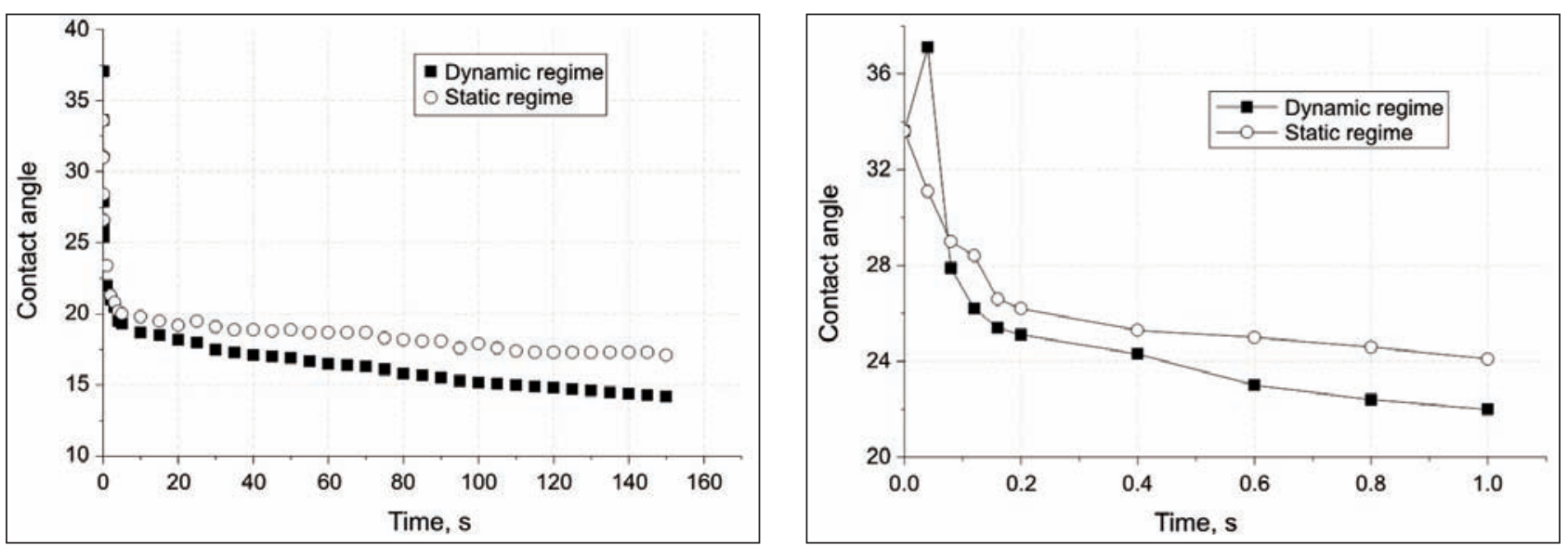

Fig. 4. Contact angle variation of the ink drop on glass plate at static and dynamic wetting regime 
the gill of glass and the polyester woven fabric. The spreading may be explained by the effect of the surface tension and the gravity of the ink which encourage this phenomenon in order to reach its equilibrium. After this phase, the diameter is stabilized and the evaporation phenomenon governs the drop behavior for the gill of glass, but the diffusion has important effect on the drop on the polyester woven fabric.

The wetting phenomenon on substrate is controlled by the surface tension and viscosity of the liquid and the surface energy of the solid. Therefore these parameters have a remarkable effect on the wetting phenomenon and especially for the dynamic regime as the projection of the drop on the polyester woven fabric which reflects the ink jet printing on the textile surface. The projection of the ink drop on textile fabric was done in free fall method. The figure 3 shows important deformation of the drop profile just after first impact drop/substrate. Then, the drop begins to spread on the solid surface and the kinetic energy of the drop is converted into surface energy. The deformation or rebound is very important in the state of the polyester woven fabric. This is may be explained by the surface energy of this material contrarily to the glass plate which has been made very absorbent by the applied treatment. This deformation is caused by the opposition of the energy of surface of the substrate to the inertia of the drop that provokes the variation of its contact line. The variation of the drop profile just after impact is confirmed by the variation of the contact angle shown in figure 4. The contact angle increases after its impact on the substrate and relaxes to equilibrium ulterior.

Thus, this phenomenon of retraction can be explained by the small air bubble can be entrapped below the drop at impact, owing to the air layer below the drop [35-37]. Then, the retraction after impact can be caused by displacements of the capillary waves of the side of the drop toward the centre [38]. The meeting of these waves provokes the capture of air bubble as shown in the figure 5 .

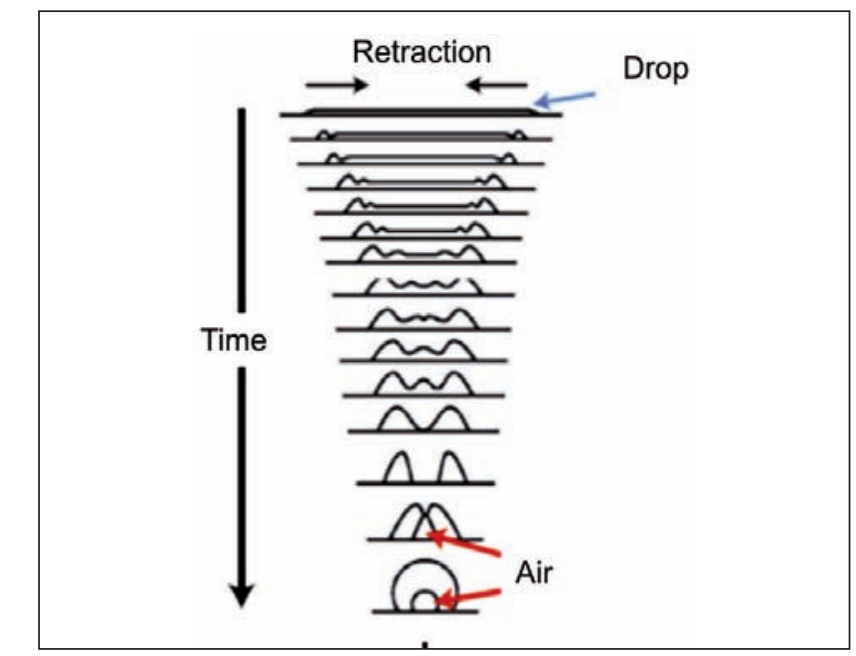

Drop

Fig. 5. Formation of an air bubble after the impact of the drop on ideal material
Therefore, the static wetting regime shows two phases contrarily to the dynamic wetting regime where three phases was considered. For the static wetting, the spreading controls the drop in first instants and evaporation governs the evolution of the drop profile at long time on the glass substrate. On the textile material, the spreading controls this phenomenon at short first time but the diffusion governs it beyond these instants. For the dynamic wetting, three phases were considered, the rebound or the drop deformation at short first instants consistent by the important spreading and the increase of drop diameter finished by stabilization state. Therefore, the most remarkable difference is the rebound of the drop which is very important for the polyester woven fabric indicating its energy of surface bigger than the glass substrate.

Finally, to lead this study, the parameters effect on the ink jet printing of textile fabric was studied such the drying temperature. We are interested to prepare a thin film of dispersive coating paste and dried in dried-ambient conditions and oven conditions $\left(110^{\circ} \mathrm{C}\right.$ during 2 minutes as in industrial scale). The wetting phenomenon on this film shows the presence of three phases of the drop impact on the polyester woven fabric. The drop rebound in first instants followed by the important spreading and finished by the third phases where the diameter is constant and the height and volume continue to decrease. The spreading rate on the ambient-dried coatings, through much lower as compared to oven-dried coating. This was analyzed by the notion of reservoir or the volume of the coating film is rightly below the area contact of the drop as demonstrated by [39].

In order to really succeed this work, in others different parameters we are interested to the ambient drying conditions. This choice is explained by the important experiment time of the wetting phenomenon which let us to better analyze different phases of this phenomenon as the spreading, the diffusion and the evaporation.

\section{Effect of surface tension of liquid}

The effect of the surface tension on the drop impact on the glass plate is studied using water and ink solution. The variation of the adimensionals parameters at the short and long times is given in the figure 6 . The variation of these parameters (diameter, height and the volume) show that for both used liquids (water and ink solution) the wetting phenomenon presents three phases. The rebound deformation just after drop impact generates a reduction of the spreading diameter and an increase of the height whereas the volume remained at least more intact (figure 6 at the short times). During second phase, we distinguish a fast increase of the diameter to reach its maximum during the first 3 seconds for ink and the 10 first seconds for water. Beyond these, time, the height and the volume continue to decrease slowly. It indicates the presence of the evaporation phenomenon during the long times. Therefore, the profile of the drop is controlled by the spreading phenomenon during the 
first and the second phase whereas it is governed by the evaporation during the third phase. The kinetics and the amplitude of spreading are more important for ink solution. It is explained by the fact that the surface tension of ink is weaker than the one of water, thus encouraging the spreading phenomenon. Thus, this result may be explained by the fact that low-energy liquids (ink solution) spread rapidly on high-energy surfaces. Therefore, the woven fabric pores will be covered by a film of liquid if they exhibit a high surface energy.
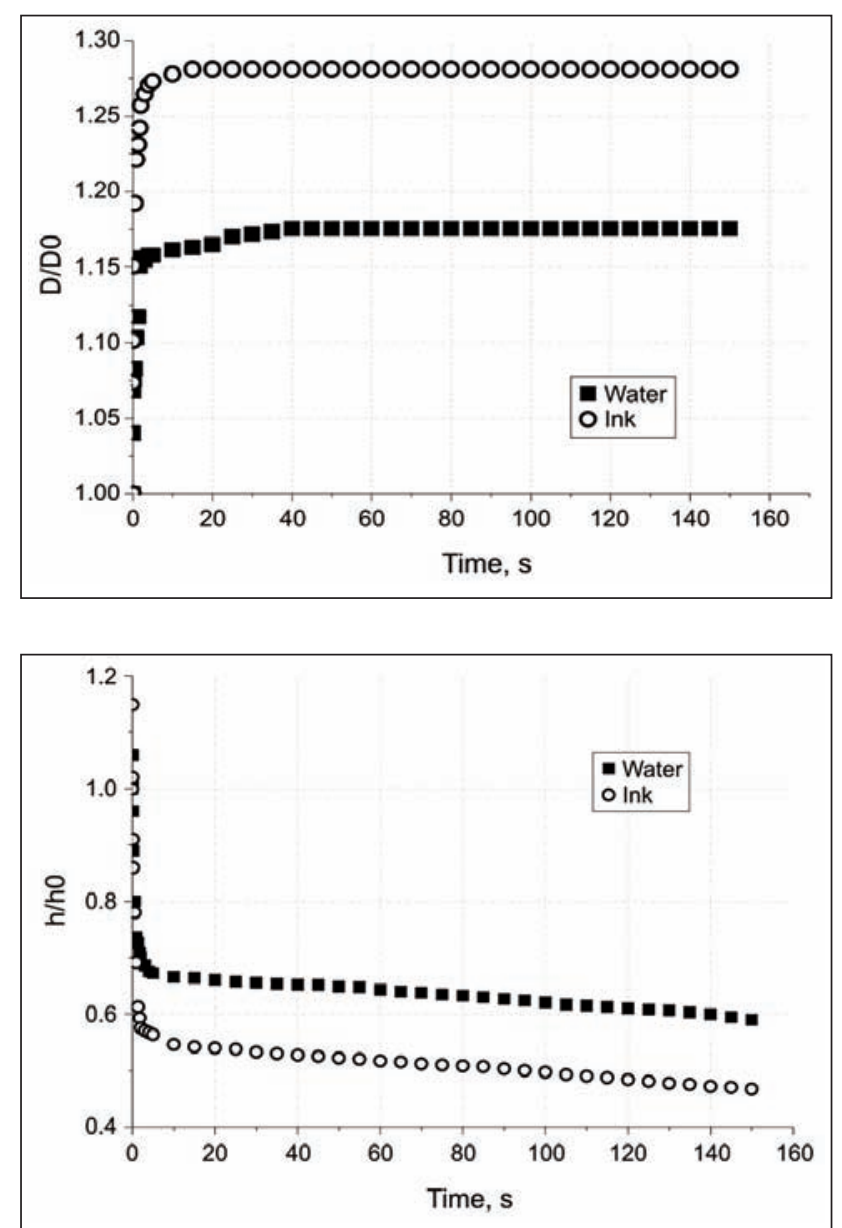

a

b

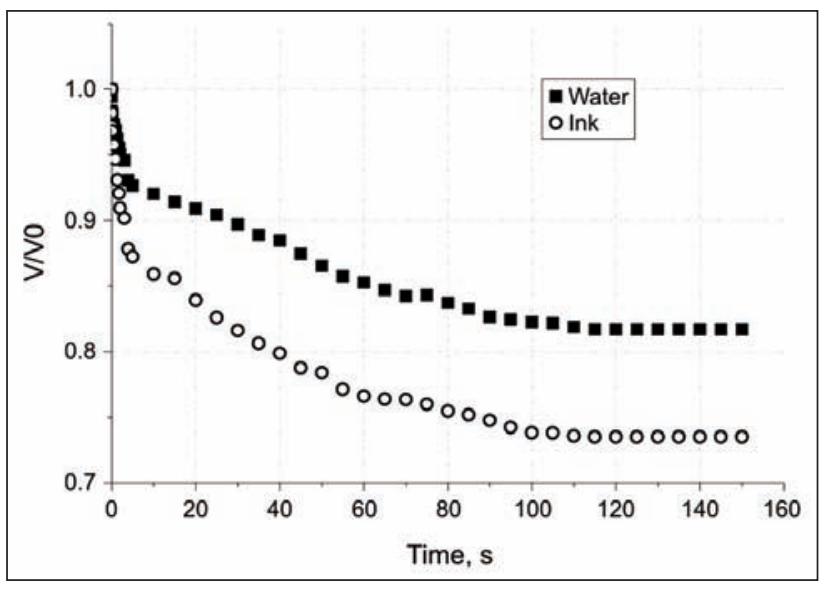

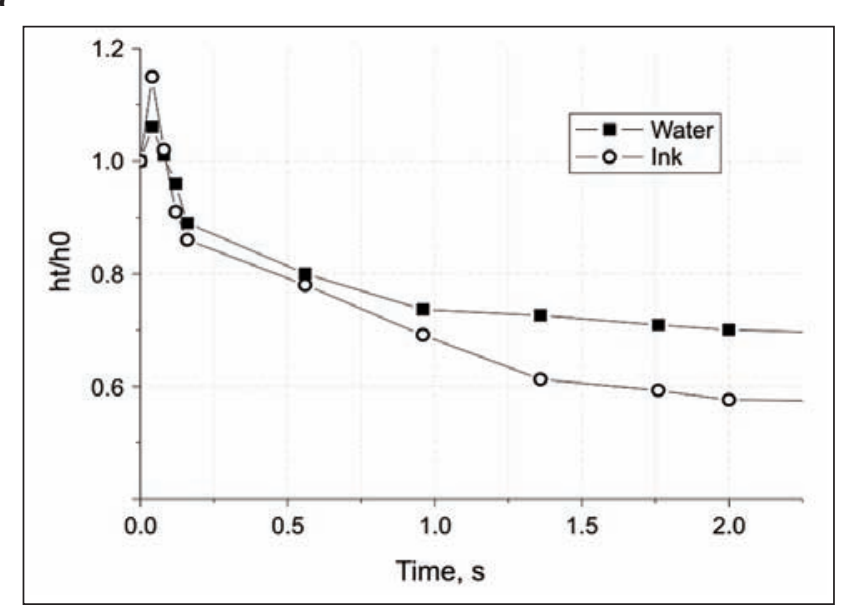

The water is a highly polar liquid that can forms strong hydrogen bonds with polar groups in the substrate molecules. These interactions may not occur with weakly-polar molecules where the principle inter-molecular forces are dispersive or Van Der Waals forces. This liquid characteristic affects directly the wetting phenomenon and the kinetic of drop spreading.

\section{Effect of projection height}

For this experiment, the drop will be projected on the support under the effect of its own weight. Three heights (static deposit $(0 \mathrm{~cm})$, the fall from $5 \mathrm{~cm}$ and
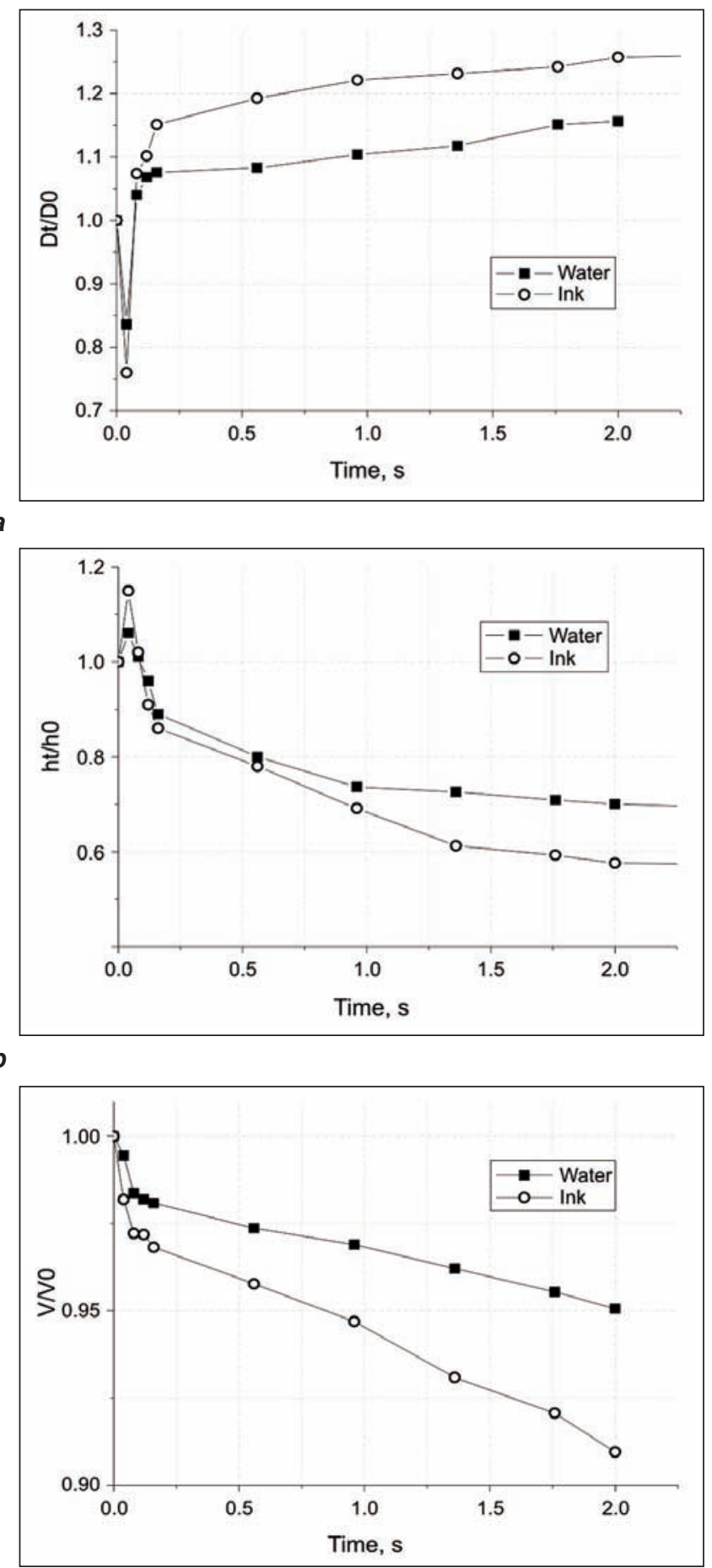

c

Fig. 6. Drop wetting kinetic of two droplets; water and ink of volume $5 \mu \mathrm{L}$ on the glass substrate at the short and long times: $a$ - evolution of the diameter, $b$ - evolution of the height, $c$ - evolution of the volume, adimensionals 
$10 \mathrm{~cm}$ ) were used to study the drop - glass plate effect on the phenomenon impact. Kinetics of wetting and evaporation according to different studied heights is given by the figure 7 .

In general, the wetting phenomenon is subdivided in three phases. The first phase was observed after the knocking drop - support. Important deformation is observed for the highest fall height. It is explained by the most elevated energy directly related to the variation of the projection height. Therefore this energy has been transformed in surface energy which has the tendency to bring the drop rightly to an important retraction after the impact. Then, it has the tendency to consolidate it (maximal spreading) more quickly
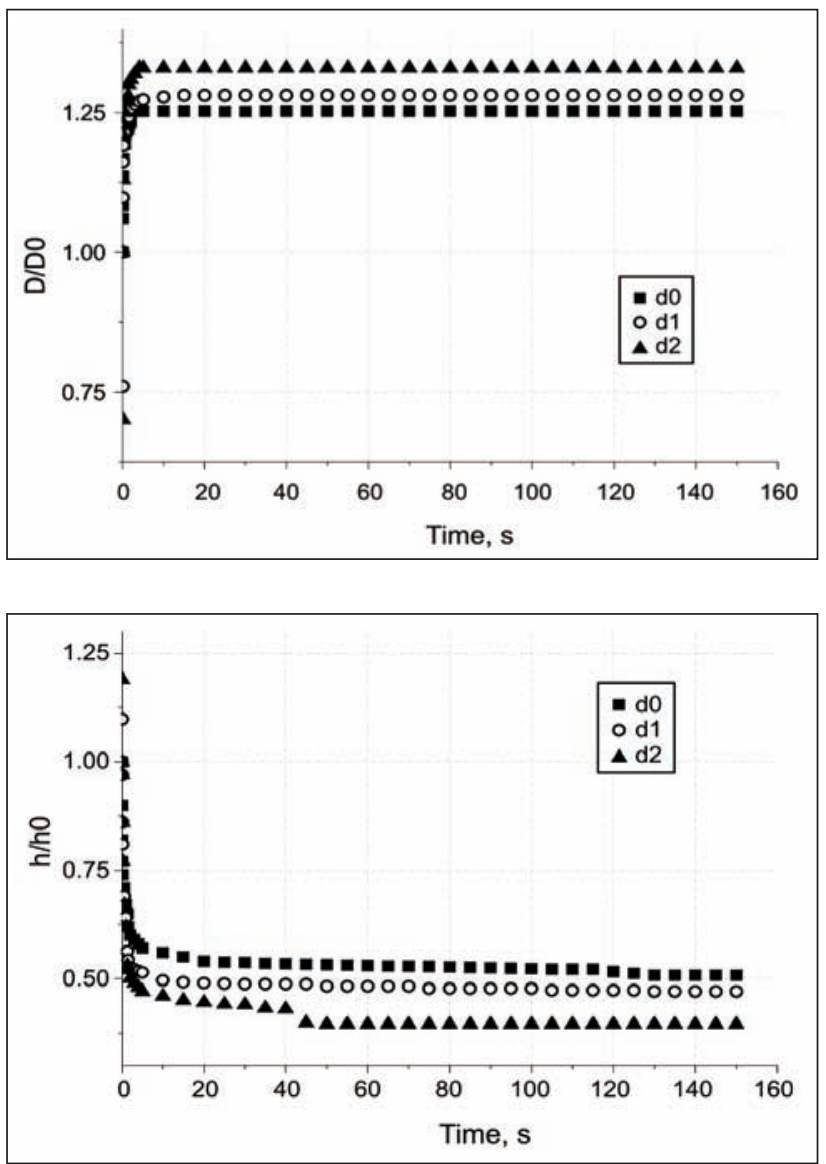

a

b

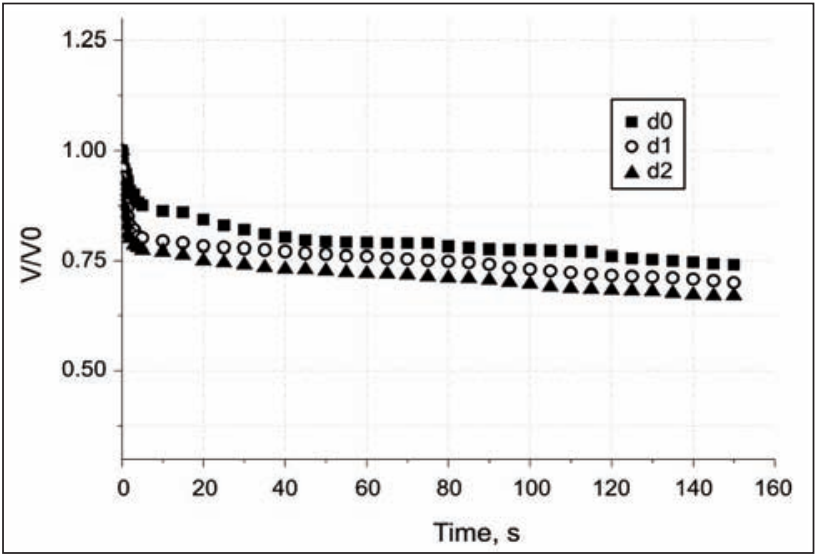

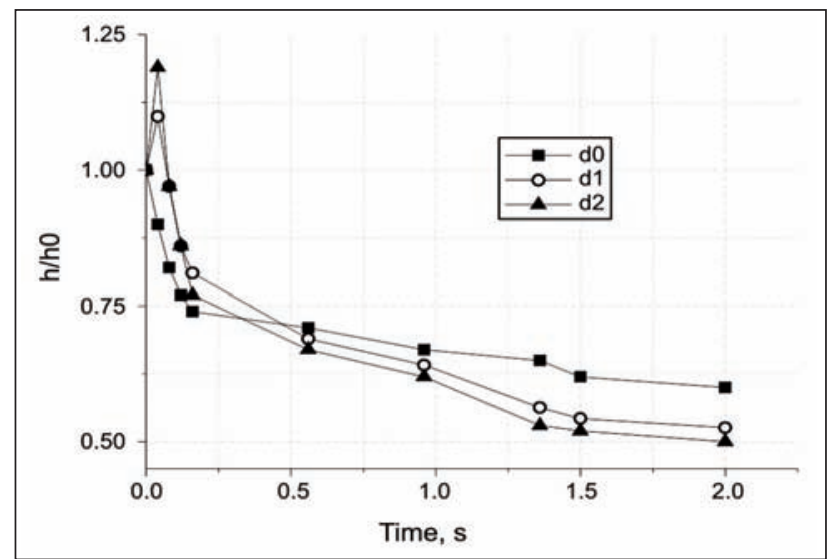

subsequently. Thus, the kinetics and amplitude of spreading are more important for the most elevated projection height.

A second phase, in which the drop spreads until all the initial energy is transformed in surface energy. Thus, the maximal spreading is reached, all the mechanical energy meets under the shape of surface energy. Finally, the diameter of the drop stabilize, the height is almost constant with a weak variation of the volume explained by a weak evaporation during this phase. Finally, the drop is governed by the spreading phenomenon at the short times and by the evaporation at the long times. Also, the height of fall possesses an influence on this phenomenon. The kinetics
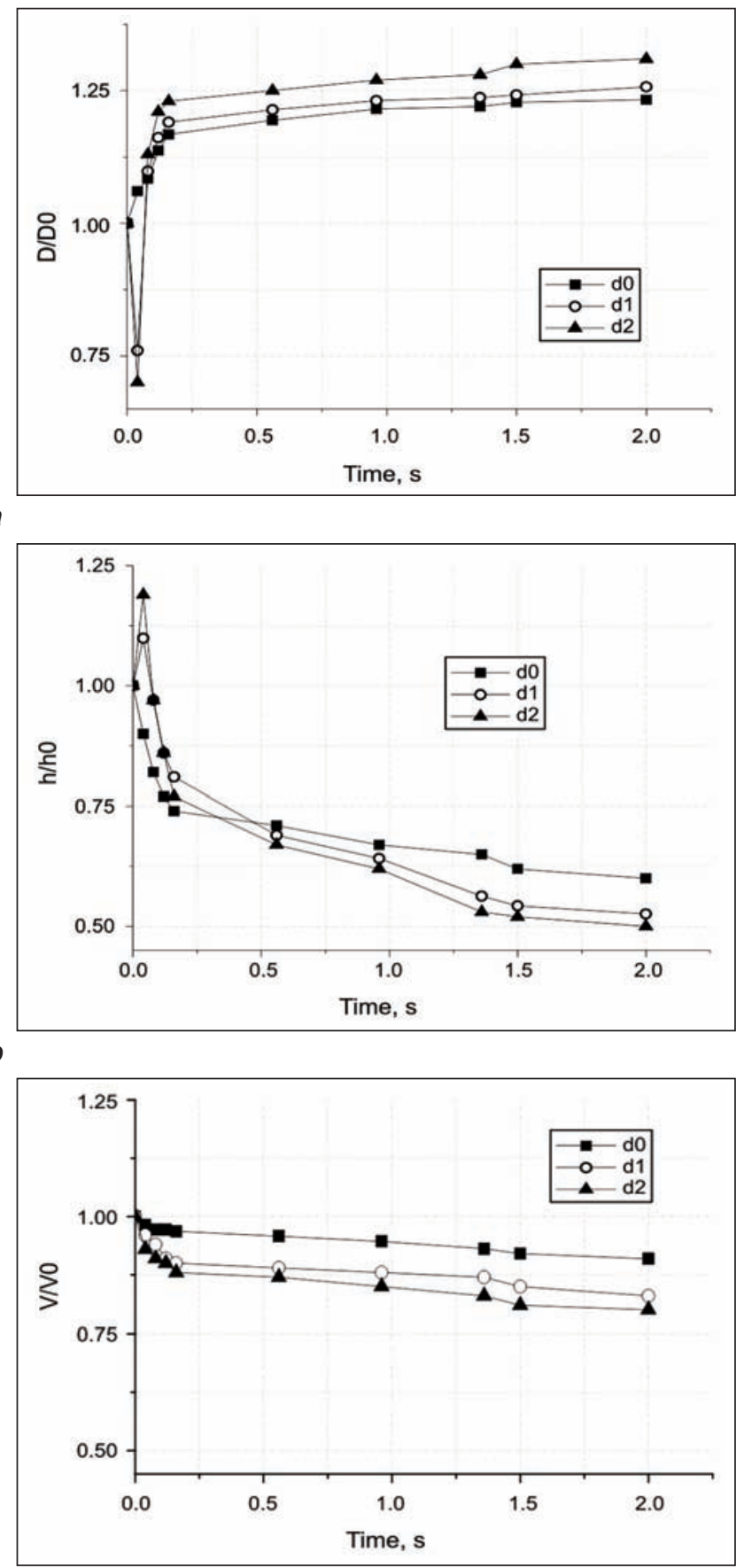

c

Fig. 7. Drop wetting kinetic of ink solution of volume $5 \mu \mathrm{L}$ on glass plate at the short and long times: $a-$ evolution of the diameter, $b$ - evolution of the height, $c$ - evolution of the volume, adimensionals 
and the spreading amplitude are more important for the highest projection distance.

\section{Effect of fabric parameters}

\section{Effect of weft count}

While varying the weft count, the capillaries sizes vary what is going to have an impact on the transportation of fluid in cloths. For this reason, we choose to study cloths having the same chemical features but that differ solely by the weft count. To analyze the effect of the weft count on the phenomena existing during the dynamic wetting of the ink drop on the tex-

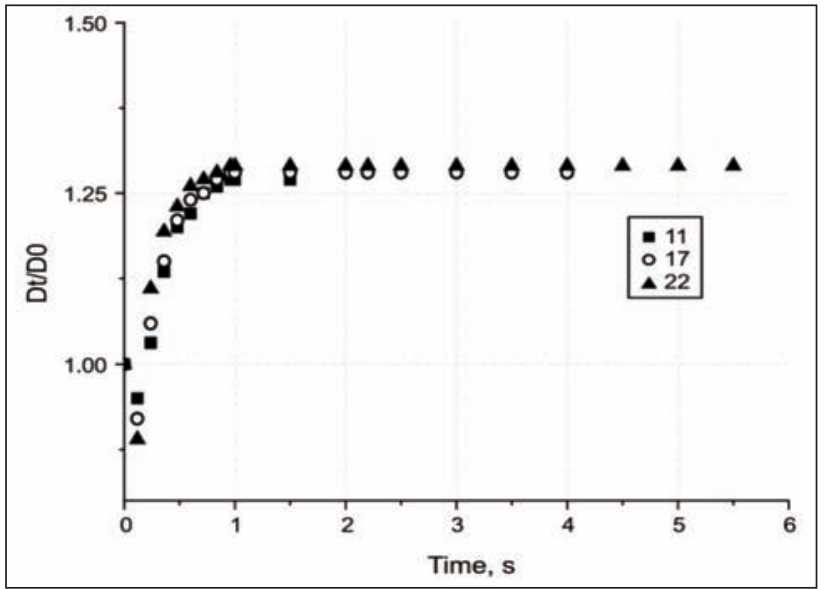

a

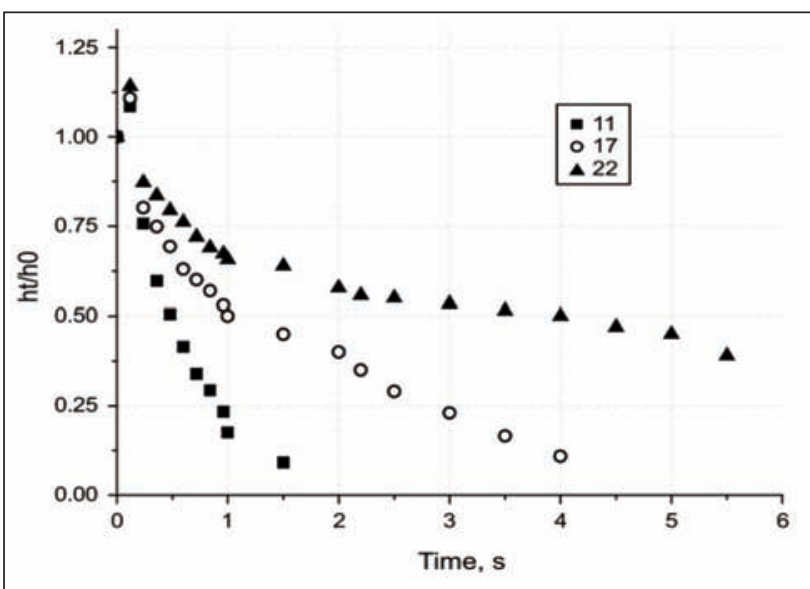

b

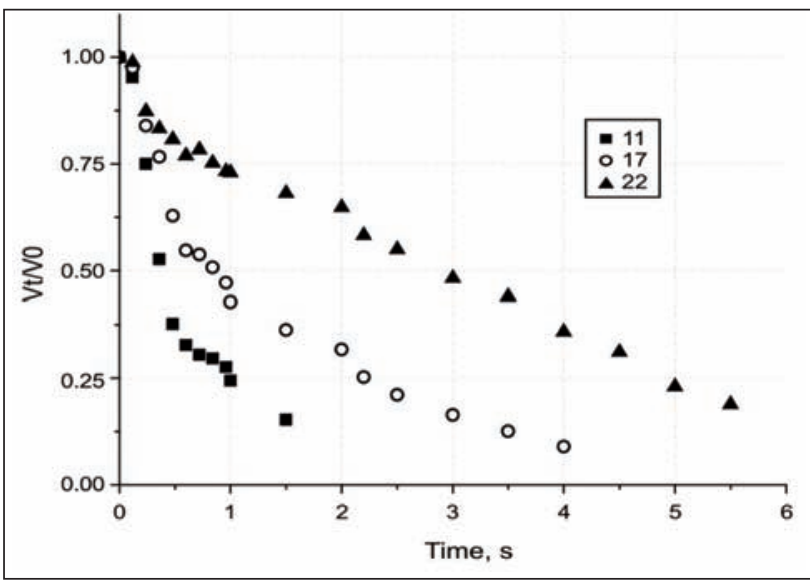

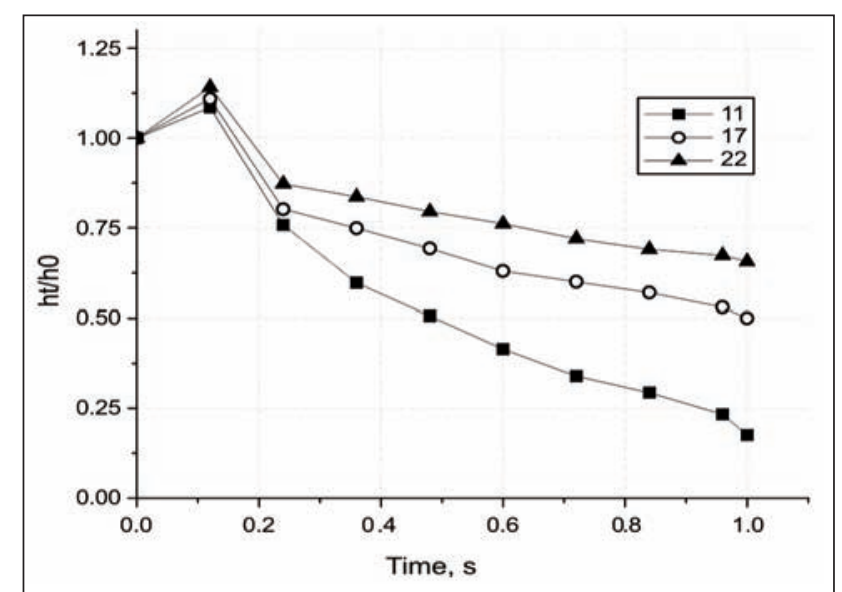

tile support. We have resort to three accounts in different weft count 11, 17 and 22. The used material is $100 \%$ polyester woven fabric which treated by dispersive coating paste. The same height of fall is used as well as the volume of the ink drop that is of $5 \mu \mathrm{L}$. The graphs characterizing the behavior of the drop The figure shows the drop deformation amplitude according to the weft count. It is smaller for the weakest weft count what can be explained by the important spaces inter-yarns which generates larger capillaries. It is obvious that the structure of the textile
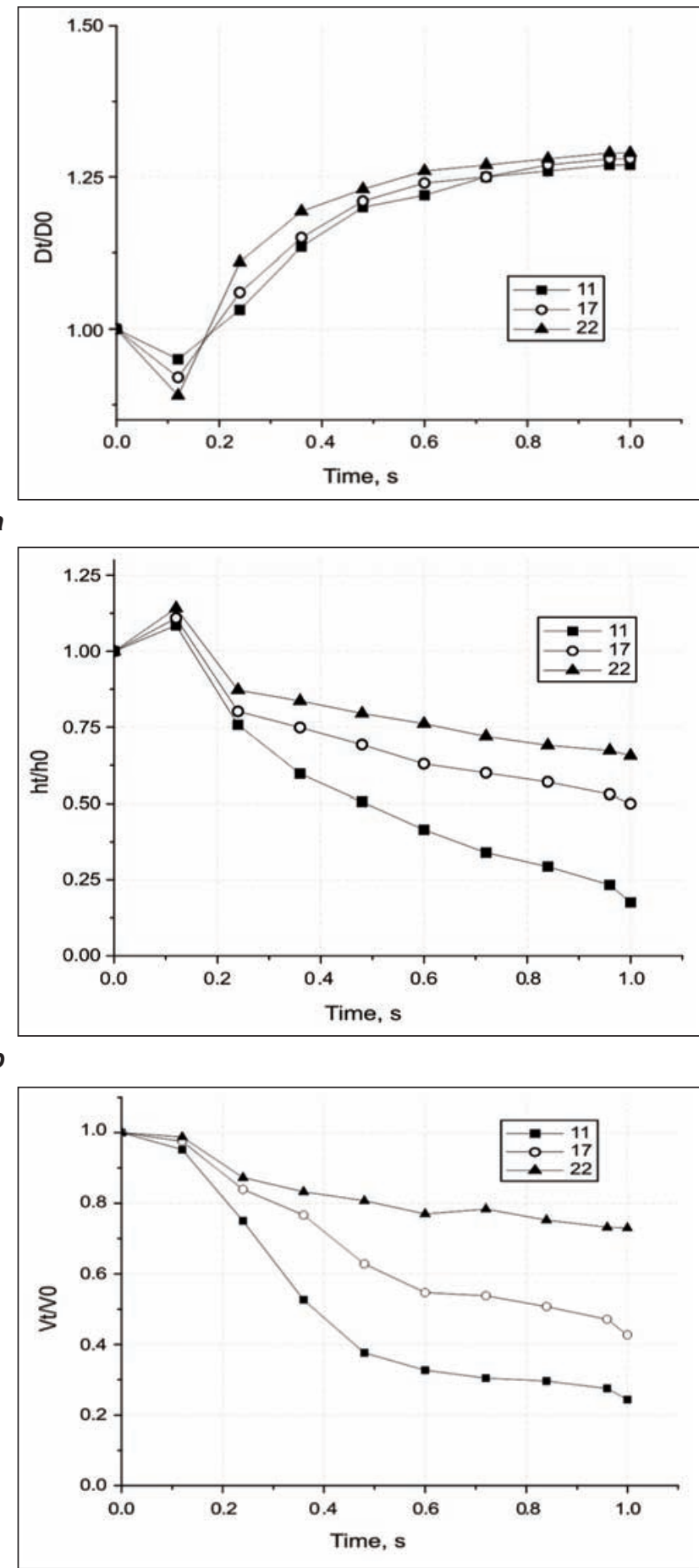

$c$ during this phenomenon are given by the figure 8 .

Fig. 8: Drop wetting kinetic of ink drop of volume $5 \mu \mathrm{L}$ on the treated textile and dried ambient temperature: $a-$ evolution of diameter, $b$ - evolution of the height, $c$ - evolution of the volume, adimensionals 
support controls the rate of spreading and diffusion of the liquid. The profile of the drop presents important deformation, after impact, for the raised weft count. It can be explained by the fact that the surface energy of the drop is very important which opposed to drop energy. It generates elevated energy provoking an important drop deformation after impact. Therefore, while increasing this factor the total surface of liquid contact - fiber is very important. Besides, the two parameters that characterize the porous environment are its porosity and its permeability. The dynamic wetting regime presents three phases; the first phase in which important drop deformation in the vertical direction is observed rightly after impact (figure 8).
The second phase in which the drop surface contact diameter increases rapidly to reaching its maximum. Finally, the third phase is the stabilization of the diameter and the total diffusion of the liquid drop in the textile support.

\section{Effect of fabric composition}

The effect of the cloth composition on the wetting of the ink drop was about supports at different compositions; mixture 50/50 cotton - polyester and 100\% polyester. The two cloths are treated by dispersive coating paste and are dried to ambient temperature. The intended drops have a volume of $5 \mu \mathrm{L}$. The different results of analysis are given by the graphs of the figure 9 .
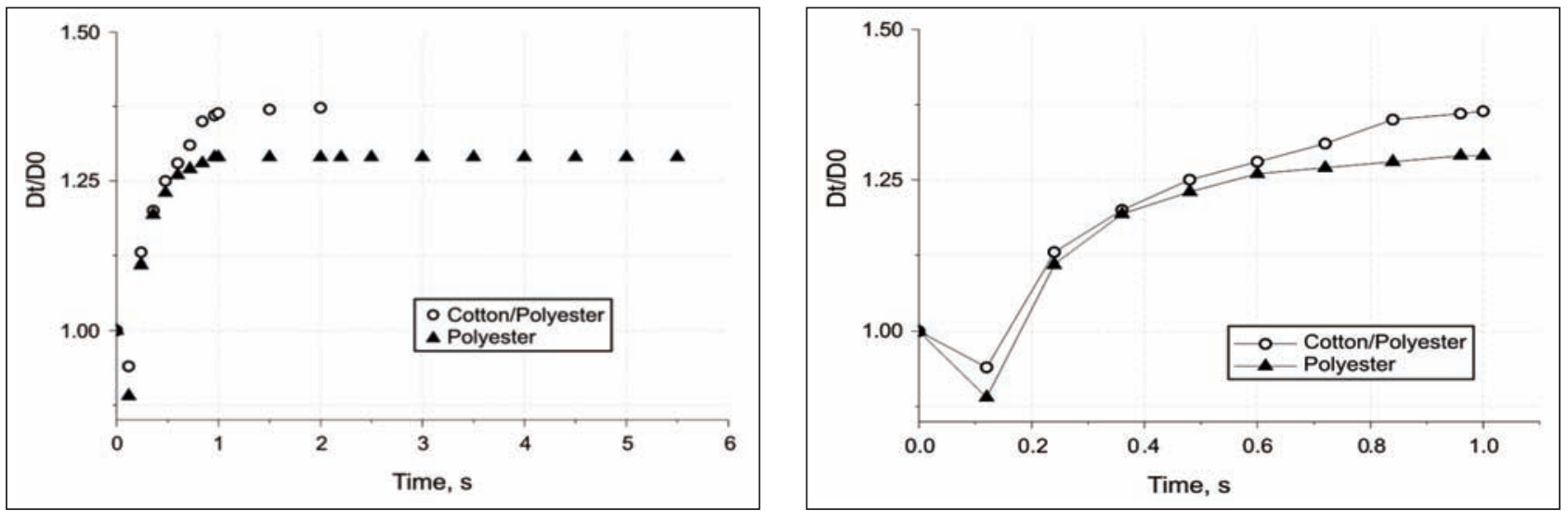

a
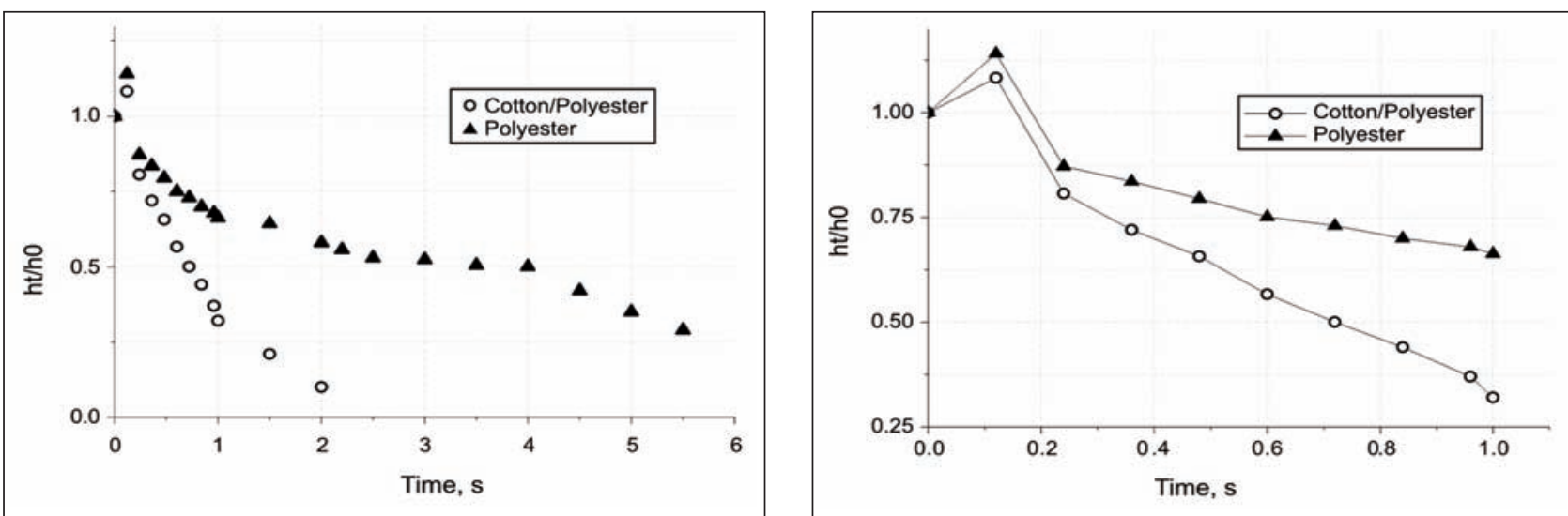

b
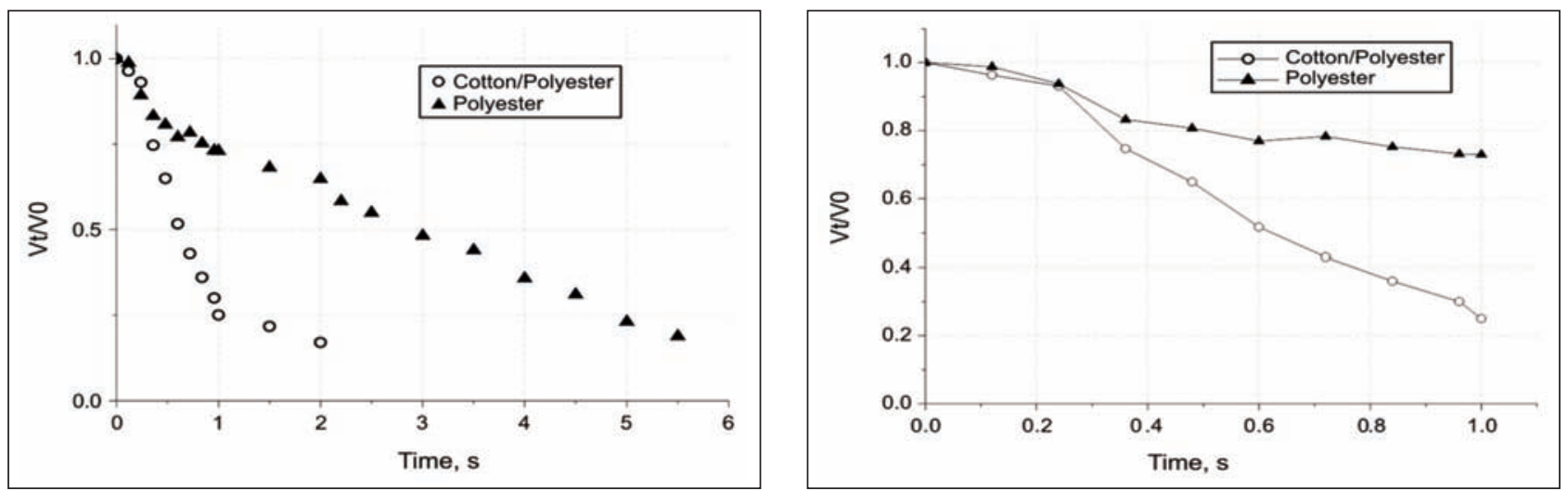

c

Fig. 9: Drop wetting kinetic of ink drop of volume $5 \mu \mathrm{L}$ on the treated textile $(100 \%$ polyester and blend polyester/cotton) and dried ambient temperature: $a$ - evolution of diameter, $b$ - evolution of the height, $c$ - evolution of the volume, adimensionals 
The same phases of dynamic wetting are observed for the two textile compositions. The duration of every phase varies from a structure to the other. The deformation is more important for cloth made of polyester. This pick of retraction of the drop believes proportionally with the energy of surface of the structure and the hydrophobicity of the composition. Besides, the profile of the drop is controlled by the spreading that is more important in the case of blend fabric. It explains itself by the absorbent character of the present proportion in the structure in mixture. It accelerates the spreading phenomenon and diffusion of the liquid in relation to the structure in $100 \%$ polyester. This can be explained that the woven fabric contains following three porosity scales in which the water molecules can be diffused (macropores, mesopores and mocropores). Indeed, the water can only enter the cotton fiber in its amorphous region, as the inter polymer spaces in the crystalline regions are too small for the water molecules.

What gives important kinetic and spreading amplitude for the blend textile sample. Therefore, the drop is governed by the spreading for the second phase in presence of the diffusion. This last controls the profile of the drop in third phase. Thus, the spreading and the diffusion control the profile of the drop during the second phase. Whereas the evaporation is pronounced more in the case of polyester sample during the last phase.

\section{CONCLUSIONS}

In summary, the study of the two wetting regime as the static and the dynamic wetting phenomena shows three drop impact phases on surface. In the first case, rebound and deformation of the drop was in first short times for the dynamic wetting regime. This deformation is bound to the surface energy and it is very significant for the important weft count of polyester woven fabric by report the virgin glass. Then the drop spreads to reach its equilibrium on the gill of glass and its total diffusion in the textile fabric. The same state was observed for the static wetting regime where important spreading rate in first instants was observed and lately the maximum diameter was obtained.

The kinetic energy has important effect on the rebound amplitude and profile perturbation and the kinetic of spreading phenomenon. Generally, the surface properties influence deeply the drop shape and the spreading rate as the effect of the fabric composition. Moreover, the coating paste encourages the water drop spreading by increasing the hydrophilic character of the polyester woven fabric. This is may be explained that the energy of the drop is dissipated by viscous forces, and converted into surface energy which increase the spreading rate as the free surface area is greatly increased.

\section{BIBLIOGRAPHY}

[1] A. Marmur, Equilibrium and spreading of liquids on solid surfaces, In: Advances in Colloids and Interface Science, 1983, vol. 19, pp. 75-102.

[2] P.G. de Gennes, Wetting: statics and dynamics, In: Reviews of Modern Physics, 1985, vol. 7, pp. 827-863.

[3] A.M. Cazabat, How does droplet spread? In: Contemporary Physics, 1987, vol. 28 (4) pp. 347-364.

[4] J. De Coninck, M. de Ruijter, M. Voue, Dynamics of wetting. Current Opinion, In: Colloid and Interface Science, 2001, vol. 6, pp. 49-53.

[5] Zisman W.A., Contact angle, wettability and adhesion, In: Advances in Chemistry Series, 1964, vol. 43, pp. 1-51.

[6] Li, D., Neumann, A.W., Equation of state for interfacial tensions of solid-liquid system, In: Advances in Colloid and Interface Science, 1992, vol. 39, pp. 299-345.

[7] Kwok D.Y., Neumann A.W., Contact angle measurement and contact angle interpretation, In: Advances in Colloid and Interface Science, 1999, vol. 81(3), pp. 167-249.

[8] Spelt J.K., Li D., The equation of state approach to interfacial tensions, In: Neumann AW, Spelt JK (eds) Applied Surface Thermodynamics. Marcel Dekker Inc., New York, 1996, pp. 239-292.

[9] Young T., An essay on the cohesion of fluids, In: Philosophical Transactions of the Royal Society, 1805, vol. 95, pp. 65-87.

[10] Wenzel, R.N., Resistance of solid surfaces to wetting by water, In: Industrial \& Engineering Chemistry, 1936, vol. 28(8), pp. 988-994.

[11] Bartell F.E., Shepard J.W., The effect of surface roughness on apparent contact angles and on contact angles hysteresis. I. the system paraffin water-air, In: Journal of Physical Chemistry, 1953, vol. 57(2), pp. 211-215.

[12] Johnson R.E., Dettre R.H., Contact angle hysteresis, In: Contact angle, wettability, and adhesion Fowkes F.M Advances in chemistry series, 1964, vol. 43, pp. 112-135. Eds. Washington, DC: American Chemical Society.

[13] Eick J.D., Good R.J., Neumann A.W., Thermodynamics of contact angle. II. Rough solid surface, In: Journal of Colloid and Interface Science, 1975, vol. 53(2), pp. 235-238.

[14] Oliver J., Huh C., Mason S.G., Effect of surface roughness on wetting (theoretical), In: Colloids and Surfaces, 1980, vol. 1(1), pp. 79-104.

[15] Neumann A.W., Good R.J., Thermodynamics of contact angle. I. Heterogeneous solid, In: Journal of Colloid and Interface Science, 1972, vol. 38(2), pp. 341-358.

[16] Schwartz L.W., Garoff S., Contact angle hysteresis on heterogeneous surface, In: Langmuir, 1985, vol. 1(2), pp. 219-230. 
[17] Brandon S. Marmur A., Simulation of contact angle hysteresis on chemically heterogeneous surfaces, In: Journal of Colloid and Interface Science, 1996, vol. 183(2), pp. 351-355.

[18] Decker E.L., Garoff S., Contact line structure and dynamics son surfaces with contact angle hysteresis, In: Langmuir, 1997, vol. 13(23), pp. 6321-6332.

[19] Chen W., McCarthy T.J., Layer by layer deposition: A tool for polymer surface modification, In: Macromolecules, 1997, vol. 30(1), pp.78-86.

[20] Youngblood J.P., McCarthy T.J., Ultrahydrophobic polymer surfaces prepared by simultaneous ablation of polypropylene and sputtering of poly (tetrafluoroethylene) using radio frequency plasma, In: Macromolecules, 1999, vol. 32(20), pp. 6800-6806.

[21] C.N.C. Lam, R.H.Y. Ko, L.M.Y. Yu, A. Ng, D. Li, M.L. Hair, A.W. Neumann, Dynamic cycling contact angle measurements: study of advancing and receding contact angles, In: Journal of Colloid and Interface Science, 2001, vol. 243(1), pp. 208-218.

[22] T. Gillespie, The spreading of low vapour pressure liquids in paper, In: Journal of Colloid Interface Science, 1958, vol. 13(32), pp. 32-50

[23] Kissa, E., Capillary sorption in fibrous assemblies, In: Journal of Colloid and Interface Science, 1981, vol. 83 pp. 265-272.

[24] Leidenfrost, J. G., On the fixation of water in diverse fire, In: International Journal of Heat and Mass Transfer, 1966 vol. 9, pp. 1153-1166.

[25] Washburn, E. W., The dynamics of capillary flow, In: Physical Review, 1921, vol. 17 (3), pp. 273-283.

[26] Bell, J. M., The flow of liquids through capillary spaces, In: Journal of Physical Chemistry, 1905, vol. 10, pp. 658-674.

[27] R. Lucas, Ueber das Zeitgesetz des kapillaren Aufstiegs von Flussigkeiten, In: Kolloid Z., 1918, vol. 23, pp.15-22.

[28] R. L. Peek Jr, D. A. Mclean, Capillary penetration of fibrous materials, In: Industrial \& Engineering Chemistry Analytical Edition, 1934, vol. 6 (2), p. 85.

[29] S. M. Kumar and A. P. Deshpande, Dynamic of drop spreading on fibrous porous media, In: Colloid. Surface A. physicochemical and engineering aspects, 2006, vol. 277, pp. 157-163.

[30] Hasan, M.M.B., A. Calvimontes, A. Synytska and V. Dutschk, Effects of topographic structure on wettability of differently woven fabrics, In: Textile Research Journal, 2008, vol. 78(11), pp. 996-1003.

[31] He, B., Patankar N.A., \& Lee, J., Multiple equilibrium droplet shapes and design criterion for rough hydrophobic surfaces, In: Langmuir, 2003, vol. 19, pp. 4999-5003.

[32] Oner, D., \& T.J. McCarthy, Ultrahydrophobic surfaces; Effects of topography length scales on wettability, In: Langmuir, 2000, vol. 16(20), pp. 7777-7782.

[33] Cassie, A.B.D., Contact angles, In: Discussion Faraday Society, 1948, vol. 3, pp. 11-16.

[34] Ramaratnam, K., Iyer, S.K., Kinnan, M.K., Chumanov, G., Brown, P.J., \& Luzinov, I. Ultrahydrophobic textiles using nanoparticles: Lotus approach, In: Journal of Engineering Fibers and Fabrics, 2008, vol. 3(4), pp.1-14.

[35] Thoroddsen, S. T., Etoh, T. G., Takehara, K., Ootsuka, N., \& Hatsuki,A. The air bubble entrapped under a drop impacting on a solid surface, In: Journal of Fluid Mechanics, 2005, vol. 545, pp. 203-212.

[36] A. A. Korobkin, A. S. Ellis, and F. T. Smith, Trapping of air in impact between a body and shallow water, In: Journal of Fluid Mechanics, 2008, vol. 611, pp. 365-394.

[37] Mandre, S., Mani, M., \& Brenner, M. P., Precursors to splashing of liquid droplets on a solid surface, In: Physical. Review. Letters, 2009, vol. 102, 134502.

[38] Romdhani, Z., Baffoun, A., Hamdaoui, M., \& Rodesli S.,Drop impact on textile material: effect of fabric properties In: AUTEX Research Journal, 2014, vol. 14 (3), pp. 145-151.

[39] Romdhani, Z., Baffoun, A., Hamdaoui, M., \& Rodesli, S., Drying Morphologies and Emport Rate Effect on Wetting and Spreading Behaviours, In: Fibers and Polymers, 2013, vol. 14 (7), pp. 1157-1164.

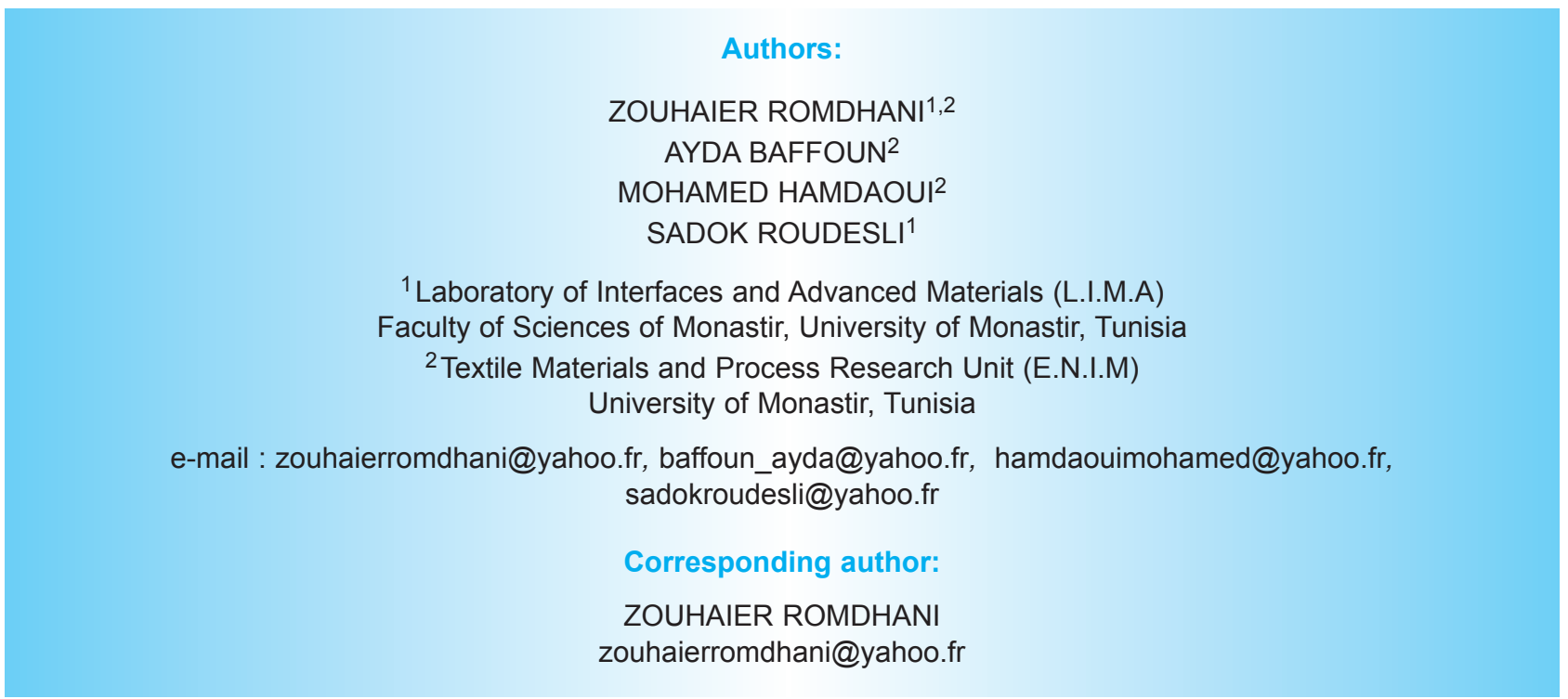




\title{
Effects of tourmaline on the voltage response of PVDF filaments
}

\author{
DOI: 10.35530/IT.068.01.1335
}

DERMAN VATANSEVER BAYRAMOL

\author{
REZUMAT - ABSTRACT
}

\section{Efectele turmalinei asupra răspunsului la tensiune al filamentelor PVDF}

Scopul acestei lucrări a fost de a investiga efectul unui material natural cristal piezoelectric asupra răspunsului la tensiune al filamentelor polimerice. Filamentele piezoelectrice pe bază de fluorură de poliviniliden (PVDF) care conțin pulbere de turmalină (TM) au fost produse cu succes. Pulberea TM a fost amestecată direct în polimer termoplastic PVDF la un raport de masă de $1 \%, 3 \%$ și $5 \%$, cu ajutorul unui aditiv. Filamente PVDF pure au fost utilizate ca materiale de control. Au fost investigate proprietățile de rezistență la tracțiune, morfologiile de suprafață şi caracteristicile de topire ale filamentelor rezultate. Conținutul piezoelectric al fazei $\beta$ a fost calculat din valorile intensității maxime la anumite numere de undă obținute prin spectroscopia în infraroşu cu transformată Fourier (FTIR). Răspunsurile la tensiune ale filamentelor au fost investigate cu ajutorul unui dispozitiv de testare a impactului şi înregistrate de un osciloscop digital. Rezultatele arată că adăugarea de pulbere TM în polimerul PVDF nu a avut un efect negativ asupra tenacității filamentelor, determinând o uşoară creştere a conținutului de fază $\beta$, iar răspunsul la tensiune a fost observat la o creştere a raportului $T M$.

Cuvinte-cheie: piezoelectric, PVDF, turmalină, extrudare prin topire

\section{Effects of tourmaline on the voltage response of PVDF filaments}

The aim of this research was to investigate the effect of a natural piezoelectric crystal material on the voltage response of polymeric filaments. Polyvinylidene fluoride (PVDF)-based piezoelectric filaments containing tourmaline (TM) powder were successfully produced. TM powder was directly blended in thermoplastic PVDF polymer at mass ratios of 1\%, 3\% and $5 \%$ via a compounder. Pristine PVDF filaments were also produced as control materials. Tensile properties, the surface morphologies and melting characteristics of resulting filaments were investigated. Piezoelectric $\beta$-phase content was calculated from the intensity levels of peaks at certain wavenumbers obtained from Fourier transform infrared spectroscopy (FTIR). Voltage responses of the filaments were investigated by an impact test rig and recorded by a digital oscilloscope. The results show that the addition of TM powder into PVDF polymer did not have a negative effect on tenacity of the filaments but a slight increase in $\beta$-phase content and the voltage response were observed with an increase in TM ratio.

Keywords: piezoelectric, PVDF, tourmaline, melt extrusion

\section{INTRODUCTION}

Piezoelectricity can be defined as electromechanical behavior of some materials which can generate electrical charge when mechanically stressed. Conversely, these materials generate mechanical strain as a result of applied electrical charge. A number of works were conducted on naturally occurring piezoelectric materials in the $20^{\text {th }}$ century [1-6]. Tourmaline is a natural noncentrosymmetric crystal material which shows pyroelectric and piezoelectric properties when subject to a temperature change and a mechanical strain, respectively. There is limited number of works on piezoelectric property of tourmaline [7].

Piezoelectric researches took a new path with the discovery of piezoelectric property on man-made piezoelectric materials, such as barium titanate $\left(\mathrm{BaTiO}_{3}\right)$, lead zirconium titanate $(\mathrm{PZT})$, polyvinylidene fluoride (PVDF) etc. [8-11]. These materials have been widely studied for the applications of direct and reverse piezoelectric effect. However, ceramic based materials have limitations of limited flexibility, brittleness and toxicity. Polymers on the other hand are flexible, non-toxic and versatile materials. Polyvinylidene fluoride (PVDF) was the first polymer discovered to show piezoelectric effect after stretched and polled at elevated temperatures [11]. Among different phases of PVDF, the most prevalent phase is nonpolar $\alpha$-phase while $\beta$-phase is the most responsible phase of piezoelectric behaviour of the polymer [12-13]. In order to produce piezoelectric PVDF material, molecular dipoles must be reoriented from nonpolar $\alpha$-phase to polar $\beta$-phase by application of stretching, polling and temperature [14].

The only drawback of the polymer based piezoelectric materials can be their low piezoelectric properties as compared to ceramic based materials. There a number of works on polymer based piezoelectric materials to increase the electrical response of the material. Tourmaline is a natural material and a kind of complex borosilicate. It contains spontaneous and permanent poles which can generate electric dipoles [15-16]. These dipoles result is an electric field on the surface of the tourmaline particle when mechanically strained [17]. In this work, a natural piezoelectric material tourmaline has been added to PVDF 
polymer and the effect of the addition of naturally occurring crystal piezoelectric material in PVDF polymer was investigated.

\section{EXPERIMENTAL WORK}

\section{Masterbatch and fillament production}

Tourmaline powder was obtained from Shanghai HuZheng NanoTechnology Company (China). Low viscosity Solef 1008 homopolymer PVDF granules used for the production of flexible piezoelectric fibres were obtained from Solvay Solexis S.A. Belgium (figure 1). PVDF has a melt flow index of $0.8 \mathrm{~g} / \mathrm{min}$ at $230^{\circ} \mathrm{C}$ and $2.16 \mathrm{~kg}$ mass with the melting point of $174^{\circ} \mathrm{C}$.

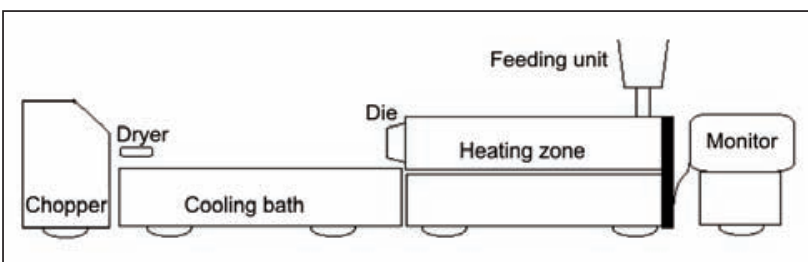

Fig. 1. Twin-screw compounding equipment and the chopper

The heating zone consists of six parts whose temperature can be controlled individually. The temperature of the heating zone is increased gradually from $180^{\circ} \mathrm{C}$ (at the heating zone 1 where the polymer/tourmaline mixture is fed) to $220^{\circ} \mathrm{C}$ (at the heating zone 6 located in front of the die). The torque of the double-screw needs to be kept below $80 \%$ to avoid any blockage. Therefore, the parameters applied for compounding were $10 \%$ feeding rate and 350 rpm twinscrew rotation speed which helps to keep the torque around $60 \%$. Fed polymer/tourmaline blend passes through six heating zone. Granular polymer melts during the travel between feeding unit and the die, and tourmaline particles get dispersed into the molten polymer. Extruded single filament passes through a cold water bath for cooling and then dried via a blower. The filament is then fed straight to the cutting unit to be cut into small pieces as granules. The sizes of the granules are dependent on the feeding percentage and diameter of the extrusion die of the compounder. Produced masterbatches were then dried at $80^{\circ} \mathrm{C}$ in the oven for 2 hours.

PVDF/TM monofilaments were produced through extrusion, drawing and simultaneous polarisation. Filament production was done in a laboratory scale single-screw melt extruder. The polymer was fed through the screw at a speed of between 1-2 rpm. The temperature profile was $100^{\circ} \mathrm{C}$ at the feeding zone and was increased gradually at three zones along the barrel, $190^{\circ} \mathrm{C}, 200^{\circ} \mathrm{C}$ and $210^{\circ} \mathrm{C}$, respectively. The die temperature was maintained at $220^{\circ} \mathrm{C}$. The speed of take-up rollers (slow rollers) and fast rollers were 10 meter per minute $(\mathrm{mpm})$ and $50 \mathrm{mpm}$, respectively. First two of six slow rollers were watercooled while other four were heated from $60^{\circ} \mathrm{C}$ to $90^{\circ} \mathrm{C}$ with $10^{\circ} \mathrm{C}$ increment. Detailed information on

\begin{tabular}{|c|c|c|c|}
\hline \multicolumn{4}{|c|}{ NOMENCLATURE OF PRODUCED PP/TM } \\
MONOFILAMENTS \\
\hline $\begin{array}{c}\text { Weight ratio } \\
\text { of PVDF } \\
(\%)\end{array}$ & $\begin{array}{c}\text { Weight ratio } \\
\text { of Tourmaline } \\
(\%)\end{array}$ & $\begin{array}{c}\text { Polarization } \\
\text { Status } \\
\text { (poled/unpoled) }\end{array}$ & Sample ID \\
\hline 100 & 0 & unpoled & UP0T \\
\hline 99 & 1 & unpoled & UP1T \\
\hline 97 & 3 & unpoled & UP3T \\
\hline 95 & 5 & unpoled & UP5T \\
\hline 100 & 0 & poled & PP0T \\
\hline 99 & 1 & poled & PP1T \\
\hline 97 & 3 & poled & PP3T \\
\hline 95 & 5 & poled & PP5T \\
\hline
\end{tabular}

piezoelectric filament production from thermoplastic polymers can be found elsewhere [18-19].

As shown in table 1, eight types of filaments were produced. The first letter of nomenclature presents the polarization status of the filament; "P" for poled and " $U$ " for unpoled. The second letter $(P)$ stands for PVDF while the number represents the amount of TM into the filament structure and the last letter $(T)$ presents TM. The optimum drawn ratio for piezoelectric behaviour of melt extruded PVDF materials was previously studied by other researchers therefore the drawn ratio in this work was chosen according to these experimental studies $[13,20-21]$. Simultaneous polarisation was taken place between temperature controlled slow rollers and the fast rollers. Two flatplate electrodes were located in this region and connected to a Spellman SL300 series high voltage power supply. A high voltage of $15 \mathrm{kV}$ was applied on to the filaments during the filament production.

Mechanical properties of filaments were investigated by using Textechno Statimat M Tensile Test Equipment. Thermal behavior of the filaments was investigated by Differential Scanning Calorimetry (DSC), TA Instruments Q2000. Very small pieces of each sample was placed in a pan and closed with a lid. After weighting, the whole sample was placed inside the furnace along with a reference pan. The samples were scanned from $-50^{\circ} \mathrm{C}$ to $200^{\circ} \mathrm{C}$ at a heat rate of $10^{\circ} \mathrm{C} / \mathrm{min}$ under nitrogen atmosphere. Analyses of the curves of DSC thermographs were carried out by Thermal Analysis software. $\beta$-phase formation of unpoled and poled filaments of pristine PVDF and PVDF/TM was analyzed by Thermo Scientific's IS10 Nicolet Fourier Transform Infrared Spectroscopy (FTIR) coupled with the smart iTR accessory. OMNIC software was used to plot the absorbance spectra as a function of wave numbers over a range of $4000-600 \mathrm{~cm}^{-1}$ and sixty four scans were accumulated for each sample. A Hitachi S-3400 N Scanning Electron Microscope (SEM) was used to examine the morphology of the samples. The microstructure images of the filaments were captured at an accelerating voltage of $5 \mathrm{kV}$ and various magnifications and compared. 


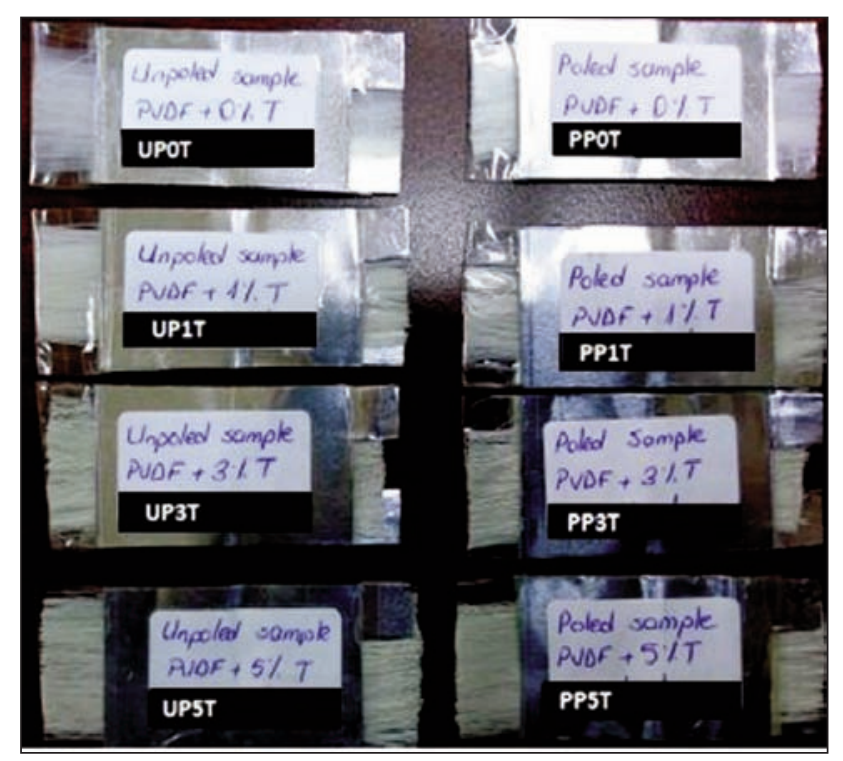

Fig. 2. Photograph of prepared samples from unpoled and poled pristine PVDF and

PVDF/TM blends (containing $1 \%, 3 \%$ and $5 \%$ tourmaline)

To investigate the voltage output of filaments, a mechanical stress should be applied onto the filaments. However, measuring the voltage output of a single filament is not easy. Therefore, produced filaments were tested for their voltage response by placing several fibres adjacent to each other between two aluminium conductive sheets with no attention to the direction of fibres. To make sure that each sample contains the same amount of material, a spinning wheel was used. A certain amount of filament was wind onto the spinning wheel then cut and inserted between two conductive sheets acting as electrodes. The whole sample structure was then encapsulated between two wide sticky tapes as shown in figure 2 . The size of the sample was $50 \mathrm{~mm} \times 30 \mathrm{~mm}$. Samples were placed in an impact test equipment (Instron Dynatup $®$ MiniTower $®$ ) which uses ASTM D 3763 standard impact test method. In this experimental work, we located a metal substrate in the equipment and the samples were fixed on this metal substrate. A weight of $1.02 \mathrm{~kg}$ was freely dropped onto the sample from a height of $5 \mathrm{~cm}$. The voltage responses of the piezoelectric sample was evaluated and recorded using a digital oscilloscope. The top and bottom aluminium sheets act as electrodes collecting the charge from the fibres.

\section{RESULTS AND DISCUSSIONS}

Linear density of the filaments has been investigated by measuring the weight of a certain length of the filaments. As aforementioned, production parameters (feeding speed, temperature, pressure etc.) on melt extruder were kept the same for each group of filaments. The counts of the filaments containing $0 \%$, $1 \%, 3 \%, 5 \%$ weight ratio of TM were measured to be 29.82 tex, 27.97 tex, 26.96 tex and 26.20 tex, respectively. The decrease in the fibre diameter can be explained by the decrease in viscosity of polymer blends as a result of TM addition. This is an agreement with the work of Safak and Karaca who produced and characterized poly(ethylene terephthalate)/tourmaline nanofibrous mats by electrospinning process and claimed that the addition of tourmaline nanoparticles resulted a decrease in nanofiber diameter [22]. Moreover, after about two hours of run, the fast rollers of the laboratory scale melt extruder were found to start accelerating with no intervention. The acceleration was a very low level that can be ignored if the equipment will be run for only a couple of hours. For longer runs, the speed should be checked frequently with a tachometer otherwise the draw ratio could change which would then result thinner filaments. Even though the draw ratio applied to the filaments was controlled by checking the speed of the slow and the fast rollers frequently in this study, it could still have a slight effect on the linear density of filaments.

Tenacity of a filament structure is an important parameter for many applications that is significantly influenced by material properties and production parameters. From Statimat $M$ test results, an increase in the tenacity of the filaments that was ranged from $35.02 \mathrm{cN} / \mathrm{tex}$ (623 MPa, based on the conversion of $1 \mathrm{MPa}=\mathrm{cN} / \mathrm{Tex}{ }^{*} 10^{*}$ specific gravity of PVDF) to $37.11 \mathrm{cN} /$ tex (660.5 MPa) was recorded with an increase in the weight ratio of TM. Tenacity of poled filaments was slightly higher as compared to the unpoled ones which having the same amount of tourmaline additive. For instance, UP3T filaments showed a tenacity of $35.02 \mathrm{cN} /$ tex (623 MPa, based on the conversion of $1 \mathrm{MPa}=\mathrm{cN} / \mathrm{Tex} * 10^{*}$ specific gravity of PVDF) while it was measured to be $35.10 \mathrm{cN} / \mathrm{tex}$ (625 MPa) for PP3T filaments. Therefore, it is possible to comment that this slight difference between the tenacity of unpoled and poled filaments was insignificant. It should be noted that addition of tourmaline nanoparticles resulted an increase in the tenacity of the filaments which is in agreement with the work reported by Sencadas et al. They claimed that better mechanical properties were observed on poled PVDF films as compared to the unpoled PVDF films. It was concluded that this increase was fundamentally due to the enhanced orientation of dipoles in the interphase region of the ferroelectric polymer.

All unpoled and poled samples showed an endothermic melting peak in the region of $167-172^{\circ} \mathrm{C}$ which comprises previously reported melting temperature (Tm) of $\alpha$-phase PVDF: $167^{\circ} \mathrm{C}$ and $174^{\circ} \mathrm{C}$ [23-24]. Gregorio claims that Tm of $\alpha$-phase PVDF and $\beta$-phase PVDF are very similar but $\gamma$-phase has a slightly higher melting point which is dependent on the $\gamma$-phase crystallisation: from melt or $\alpha$-phase transformation [25]. Figure 3 shows the DSC curves of PVDF granules, UPOT and PPOT filaments to identify the effect of melt extrusion and poling on the melting characteristics of PVDF materials. A small shift was observed on melting enthalpy of the poled PVDF filament as compared to unpoled PVDF filament which is in agreement with the melting characteristics reported for $\alpha-, \beta$ - and $\gamma$-phases of PVDF [26]. 


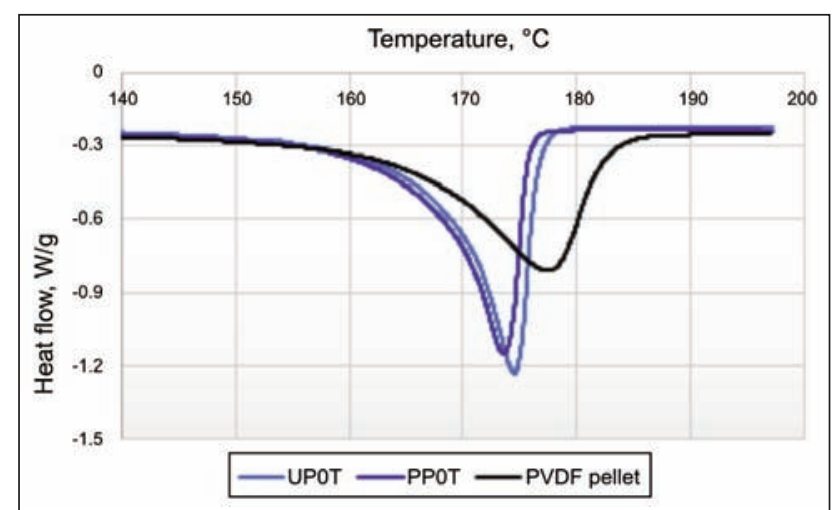

a

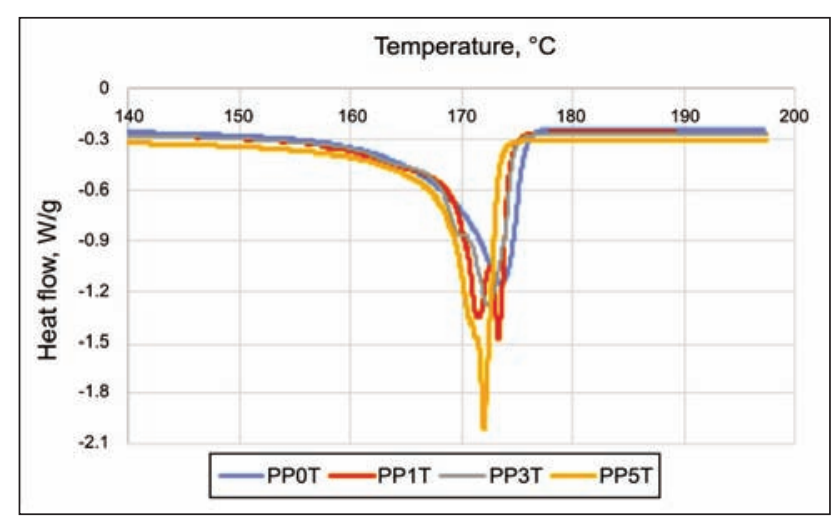

b

Fig. 3. DSC traces for: a - pristine PVDF materials; pellets, unpoled and poled filaments and $b$ - polarized PVDF filaments; PP0T, PP1T, PP3T and PP5T performed at $10^{\circ} \mathrm{C} / \mathrm{min}$

The degree of crystallinity $\left(\Delta X_{c}\right)$ was calculated from melting enthalpy $\left(\Delta H_{m}\right)$ of filaments and the melting enthalpy for $100 \%$ crystalline PVDF $\left(\Delta H_{m} 100\right)$ was taken as $104.07 \mathrm{~J} / \mathrm{g}$ [27-28]. It was observed that the crystallinity was enhanced from $38.60 \%\left(\Delta X_{c}=40,40\right.$ $\mathrm{J} / \mathrm{g})$ up to $48,66 \%\left(\Delta X_{c}=50.95 \mathrm{~J} / \mathrm{g}\right)$ as a result of stretching on the melt extruder which is in agreement with the effect of stretching on crystalline structure reported for PVDF thin films [29]. However, the polarization was found not to have a significant effect on the percentage of crystallinity for this experimental study. The reason to this may be that the applied high voltage was $15 \mathrm{kV}$ which is quite lower than what is reported in literature $[20,30]$. Polarization at higher voltages may have a distinguished effect on the crystallinity of the material. Although, DSC curves give an idea about the crystallinity of the material, it is inadequate for investigation of the different crystalline phases of the PVDF filaments.

Determination of the polar $\beta$-phase formation of produced monofilaments was carried out via an FTIR equipment coupled with the smart iTR accessory (figure 4). The FTIR analyses were carried out three times for each type of monofilament (from UPOT to PP5T). Before the filament was placed on the equipment, 5 to 10 metres of filament was removed from the spool. FTIR spectras of filaments were used to determine and quantify the $\beta$-phase of eight different monofilaments. It is reported in the literature that peaks at specific wave numbers of FTIR absorbance/ transmittance bands present the $\alpha$-phase and $\beta$-phase of PVDF. Particularly, the peaks at wave numbers $760 \mathrm{~cm}^{-1}$ and $840 \mathrm{~cm}^{-1}$ are related to $\alpha$-phase and $\beta$-phase, respectively [31-33]. Piezoelectric property of PVDF is related to the amount of $\beta$-phase which is calculated by following equation (1):

$$
F(\beta)=\frac{X_{\beta}}{X_{\alpha}+X_{\beta}}=\frac{A_{\beta}}{\left(K_{\beta} / K_{\alpha}\right) A_{\alpha}+A_{\beta}}
$$

where the $F(\beta)$ is the $\beta$-phase content; $X_{\alpha}$ and $X_{\beta}$ are the crystalline fraction of $\alpha$ - and $\beta$-phase, respectively; $A_{\alpha}$ and $A_{\beta}$ are the absorbance at the specific wave numbers for $\alpha$ - and $\beta$-phase; $K_{\alpha}$ and $K_{\beta}$ are the

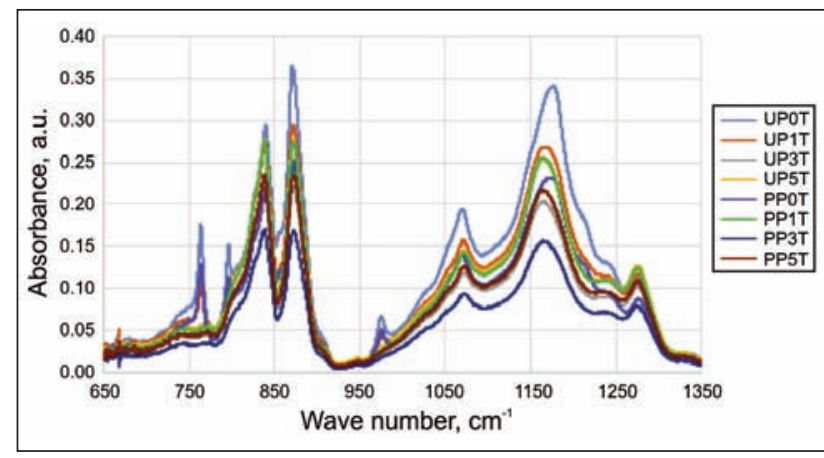

Fig. 4. Absorption spectrum of unpoled (UP0T, UP1T, UP3T, UP5T) and poled (PP0T, PP1T, PP3T, PP5T) filaments

absorption coefficients; $6.1 \times 104 \mathrm{~cm}^{2} / \mathrm{mol}$ and $7.7 \times 104$ $\mathrm{cm}^{2} / \mathrm{mol}$, respectively $[23,26,34]$. $\beta$-phase contents of the PVDF pellets, PVDF/TM masterbatches, produced PVDF and PVDF/TM filaments are calculated by using above equation. The results exhibited that $\beta$-phase contents of unpoled filaments were increased from $56 \%$ to $68 \%, 79 \%$ and $81 \%$ with an increase in TM. Similar results were observed for poled filaments that the results for these filaments (PP0T, PP1T, PP3T and PP5T) were 57\%, 79\%, 80\% and $82 \%$, respectively. It is possible to say that the effect of polarization on the $\beta$-phase formation of the filaments was found to be minor in this work.

The microstructure of the produced piezoelectric polymeric monofilaments was also studied under SEM. The effect of polarization on the surface morphology of pristine PVDF and PVDF/TM monofilaments was not significant. Some small voids were detected on the polarised filaments which were not exist on unpolarised filaments. However, an increase in the TM percentage in the polymer rezulted rougher filament surface as shown in figure 5, a-d. The same was observed in cross-sectional images (figure 5 , $e-f)$. Cross-section of both UP0T and PP0T filaments were smoother as compared to PVDF/TM blend filaments. Figure 5, e shows the cross-section of pristine PVDF filament while figure $5, f$ shows PVDF filament containing $5 \mathrm{wt} \% \mathrm{TM}$. The number and the size 


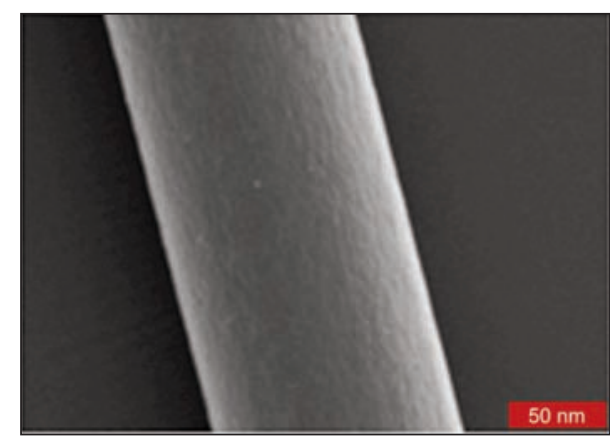

a

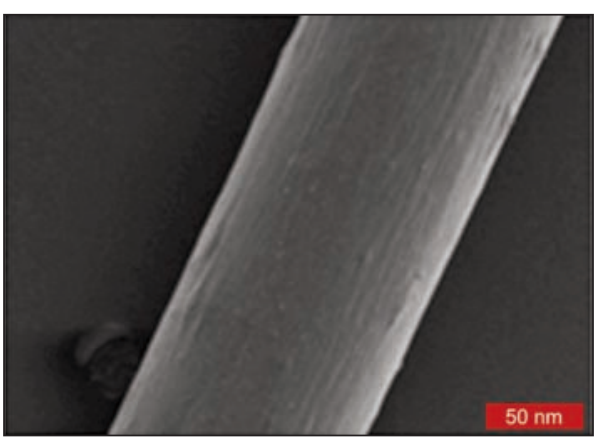

C

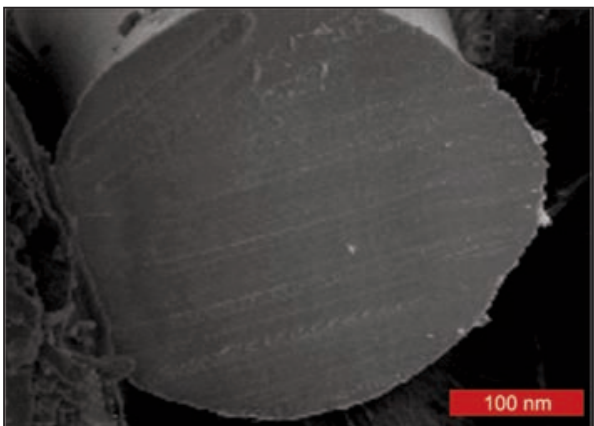

e

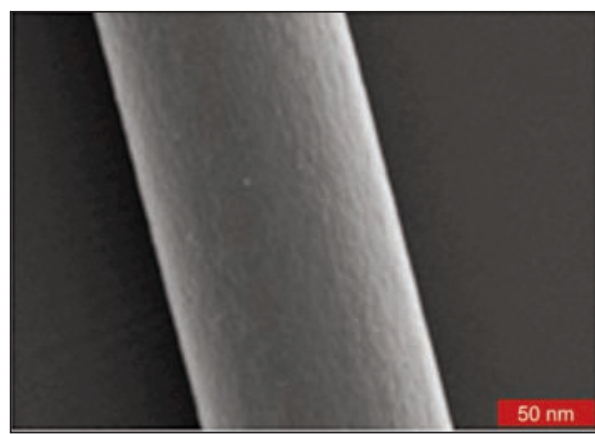

$\boldsymbol{b}$

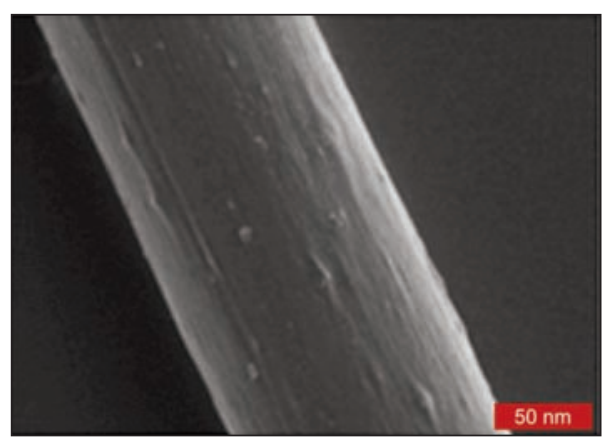

d

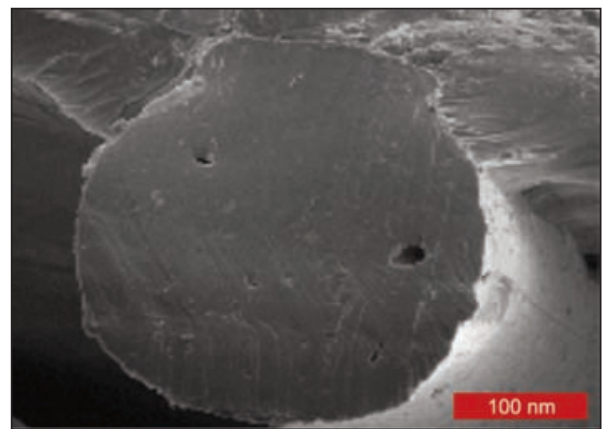

f

Fig. 5. SEM images of PVDF filaments with a weight ratio of: $a-0 \%, b-1 \%, c-3 \%$ and $d-5 \% \mathrm{TM}$; cross-sectional images of: $e-$ pristine PVDF and $f-5 \mathrm{wt} \%$ PVDF/TM filaments

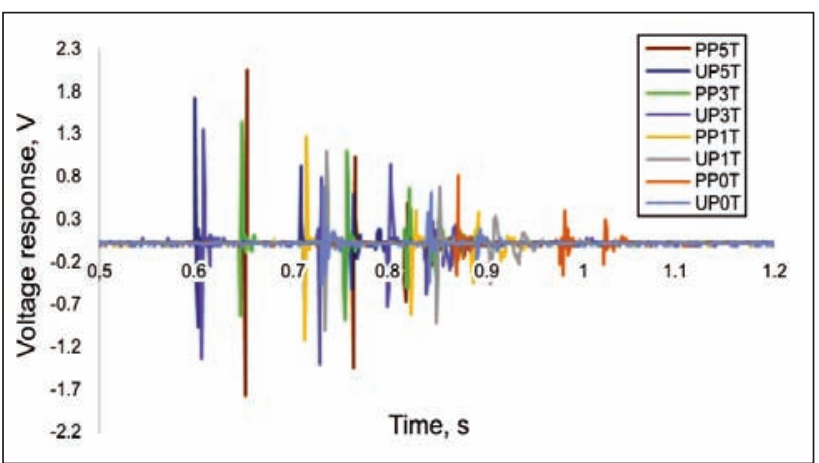

Fig. 6. Voltage responses of produced piezoelectric filaments

of the voids decreased with a decrease in TM ratio. It can be explained as the agglomeration attempt of TM particles during the melt extrusion process. Once the masterbatches melt in the heating zone of the equipment, TM particles may tend to agglomerate which then cause these voids during filament preparation for cross-sectional image. When the filament is cut in transverse direction, one side will contain agglomerated particles while the other will have the voids. From aforementioned tenacity test results, it is possible to conclude that these voids do not affect the tenacity of the filaments in a negative way.

Voltage response of produced filaments was investigated using an impact test rig and the results were given in figure 6 and figure 7 . Since the samples do not contain a resin to held the fibres in place, they tend to vibrate upon impact which results voltage generation in both negative and positive polarities. In figure 6, voltage responses of all produced filaments were shown in the same graph to indicate the differences in peak voltage generations.

To demonstrate the voltage generation characteristics of produced filaments, voltage responses of each prepared sample was given in figure 7. Peak voltage generated by samples prepared from pristine PVDF filaments, was approximately $680 \mathrm{mV}$ and $820 \mathrm{mV}$ for UPOT and PPOT, respectively. An increase in voltage generation was recorded with an increase in TM ratio in filaments. PVDF filament containing $1 \mathrm{wt} \%$ of TM showed slightly higher peak voltage generation as compared to pristine PVDF filaments. Recorded peak voltage was $1.10 \mathrm{~V}$ for UP1T and $1.28 \mathrm{~V}$ for PP1T while the voltage generated by UP3T and PP3T were $1.40 \mathrm{~V}$ and $1.44 \mathrm{~V}$, respectively. The highest peak voltage generation was observed from filaments containing $5 \mathrm{wt} \%$ of TM that was recorded as $1.72 \mathrm{~V}$ for UP5T and 2.06 $\mathrm{V}$ for PP5T. Therefore, it is possible to say that an increase in TM ratio in the filament structure resulted in an increase in peak voltage generation. A similar work should be carried out with higher TM ratios.

\section{CONCLUSIONS}

A natural piezoelectric crystal material was successfully incorporated into a polymeric material. Eight sets of piezoelectric filaments were produced. Two sets of pristine PVDF filaments were produced and one of them was polarized via a polarization unit integrated 


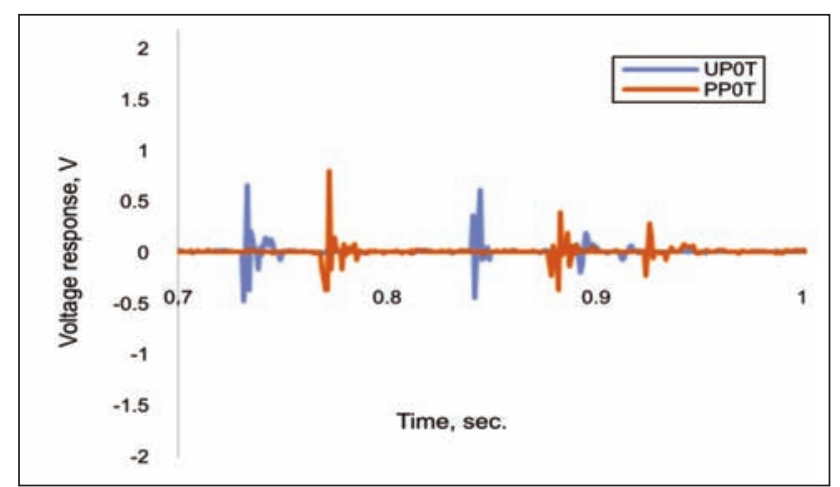

a

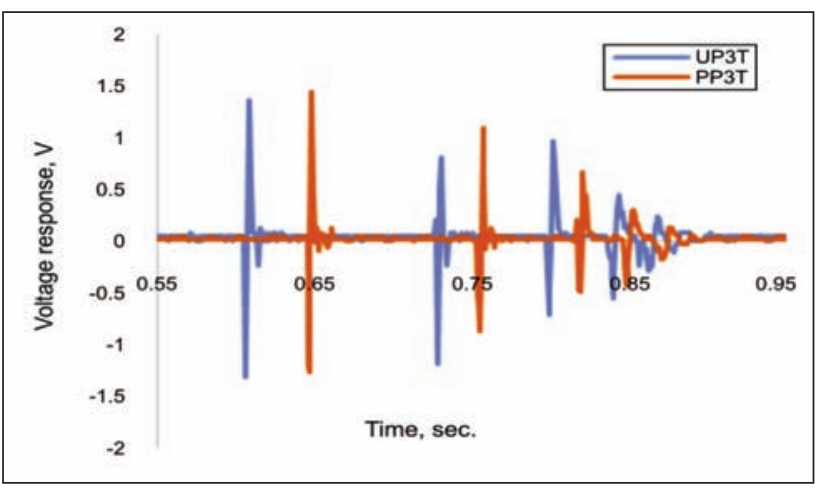

c

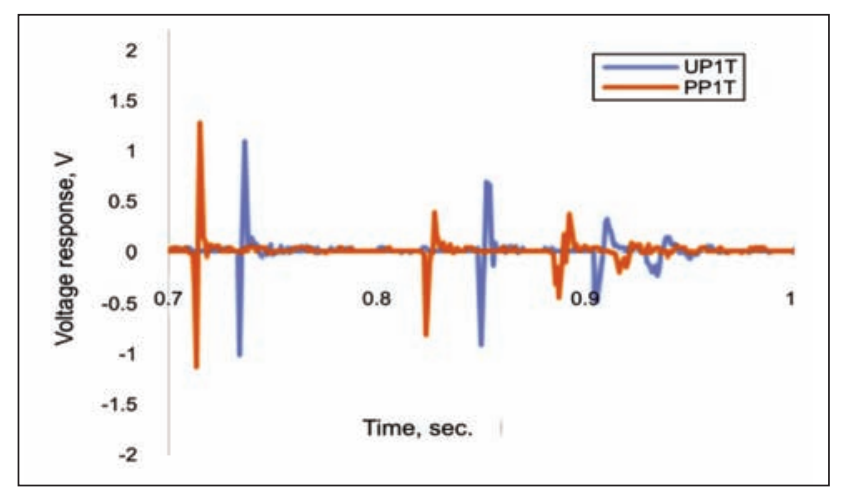

b

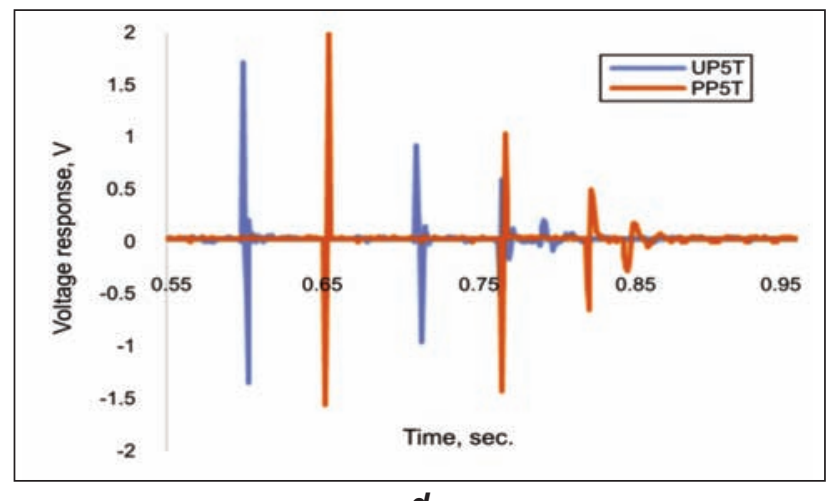

d

Fig. 7. Voltage responses of prepared samples performed on Dynatup impact test rig

to the melt extruder. Other six sets of filaments contained different ratios of naturally piezoelectric TM powder. Produced filaments were then investigated for their mechanical, thermal, structural and voltage response characteristics. Tenacity test results showed that addition of TM powder up to $5 \mathrm{wt} \%$ did not have a negative effect on the tenacity. It is calculated from the melting enthalpies of filaments obtained from DSC that the crystallinity of the filaments was increased with an increase in TM powder in piezoelectric filament. FTIR results showed that $\beta$-phase content of the filaments increased slightly with an increase in the ratio of TM. The effect of polarization was found to be low for this experimental work. The peak voltage output difference between poled and unpoled pristine PVDF filaments was $140 \mathrm{mV}$ while $5 \%$ TM addition resulted $1240 \mathrm{mV}$ increase in peak voltage output (820 mV for PPOT and $2.06 \mathrm{~V}$ for PP5T). It can be concluded that an increase in TM addition in PVDF polymer resulted in piezoelectric filaments showing higher peak voltage generation. Therefore, it can be said that addition for tourmaline powder has an influence in output voltage of PVDFbased filaments.

\section{BIBLIOGRAPHY}

[1] Fukada, E. , Piezoelectricity of wood, In: Journal of Physical Society of Japan, 1955, vol. 10, issue 2, pp. 149.

[2] Fukada, E., On the Piezoelectric effect of silk fibers, In: Journal of Physical Society of Japan, 1956, vol. 11, issue 12, pp. 1301A.

[3] Fukada, E. and Yasuda, I., On the piezoelectric effect of bone, In: Journal of Physical Society of Japan, 1957, vol. 12, number 10, pp. 1158-1162.

[4] Fukada, E. and Yasuda, I. , Piezoelectric effects in collagen, In: Japanese Journal of Applied Physics, 1964, vol. 3, number 2, pp. 502B.

[5] Fukada, E., Piezoelectricity in oriented DNA films, In: Journal of Polymer Science Part A-2, 1972, vol. 10, pp. 565-567.

[6] Fukada, E., Piezoelectric properties of organic polymers, In: Annals of the New York Academy of Sciences, 1974, vol. 238, pp. 7-25.

[7] Pandey, C. S. and Schreuer, Elastic and piezoelectric constants of tourmaline single crystals at non-ambient temperatures determined by resonant ultrasound spectroscopy, In: Journal of Applied Physics, 2012, vol. 111, issue 1 , pp. 013516.

[8] Roberts, S., Dielectric and piezoelectric properties of barium titanate, In: Physical Review, 1947, vol. 71, pp. 890.

[9] Shirane, G. and Suzuki, K., Crystal structure of $\mathrm{Pb}(\mathrm{Zr}-\mathrm{Ti}) \mathrm{O}_{3}$, In: Journal of the Physical Society of Japan, 1952, vol. 7 , issue 3 , pp. 333 . 
[10] Jaffe, B., Roth, R. S. and Marzullo, S. J Piezoelectric Properties of lead zirconate-lead titanate solid-solution ceramic ware, In: Journal of Applied Physics, 1954, vol. 25, pp. 809.

[11] Kawai, H. The piezoelectricity of poly(vinylidene fluoride), In: Japanese Journal of Applied Physics, 1969, vol. 8, number 7, pp. 975.

[12] Sencadas, V., Barbosa, R., Mano J. F. and Lanceros-Mendez, S, Mechanical characterization and influence of the high temperature shrinkage of $\beta-P V D F$ films on its electromechanical properties, In: Ferroelectrics, 2003, vol. 294, issue 1, pp. 61-71.

[13] Steinmann, W., Walter, S., Seide, G., Gries, T., Roth, G. and Schubnell, M., Structure, properties, and phase transitions of melt-spun poly(vinylidene fluoride) fibers, In: Journal of Applied Polymer Science, 2011, vol. 120, pp. 21-35.

[14] Dickens, B., Balizer, E., DeReggi, A. S. and Roth, S. C., Hysteresis measurements of remanent polarization and coercive field in polymers, In: Journal of Applied Physics, 1992, vol. 72, issue 9, pp. 4258-4264.

[15] Nakamura, T. and Kubo, T., The tourmaline group crystals reaction with water, In: Ferroelectrics, 1992, vol. 137, issue 1, pp. 13-31.

[16] Ji, Z. J., Jin, Z. Z., Liang, J. S., Wang, J. and Yan, X. W., Observation of electric dipole on polar crystalline tourmaline granules, In: Journal of Synthetic Crystals, 2002, vol. 31, pp. 503.

[17] Yamaguchi, S., Surface electric fields of tourmaline, In: Applied Physics A, 1983, vol. 31, pp. 183-185.

[18] Hadimani, R. L., Vatansever Bayramol, D., Sion, N., Shah, T., Qian, L., Shi, S. and Siores, E., Continuous production of piezoelectric PVDF Fibre for E-Textile Applications, In: Smart Materials \& Structures, 2013, vol. 22, 075017.

[19] Siores, E., Hadimani, M. L. (Ravi) and Vatansever, D., Piezoelectric polymer element and production method and apparatus therefor, EP Patent: EP2617075 B1, 2014.

[20] Shuford, R. J., Wilde, A. F., Ricca, J. J. and Thomas, G. R., Characterization and piezoelectric activity of stretched and poled poly(vinylidene fluoride). Part I: Effect of draw ratio and poling conditions, In: Polymer Engineering and Science, 1976, vol. 16, issue 1, pp. 25-35.

[21] Lund, A. and Hagstrom, B., Melt spinning of poly(vinylidene fluoride) fibers and the influence of spinning parameters on beta-phase crystallinity, In: Journal of Applied Polymer Science, 2010, vol. 116, issue 5, pp. 2685-2693.

[22] Safak, S. and Karaca, E, Production and characterization of poly(ethylene terephthalate) nanofibrous mat including tourmaline additive, In: Textile Research Journal, 2015, 10.1177/0040517515617418 (2015)

[23] Gregorio, R. and Cestari, M. J., Effect of crystallization temperature on the crystalline phase content and morphology of poly(vinylidene fluoride), In: Journal of Polymer Science Part B: Polymer Physics, 1994, vol. 32, pp. 859-870.

[24] Prest, W. M. and Luca, D. J., Formation of gamma-phase from alphapolymorphs and beta-polymorphs of polyvinylidene fluoride, In: Journal of Applied Physics, 1978, vol. 49, pp. 5042-5047.

[25] Gregorio, R., Determination of the alpha, beta, andgamma crystalline phases of poly(vinylidene fluoride) films prepared at different conditions, In: Journal of Applied Polymer Science, 2006, vol. 100, pp. 3272-3279.

[26] Martins, P., Lopes, A. C. and Lanceros-Mendez, S., Electroactive phases of poly(vinylidene fluoride): Determination, processing and applications, In: Progress in Polymer Science, 2014, vol. 39, pp. 683-706.

[27] Nakagawa, K. and Ishida, Y., Dielectric relaxation and molecular motions in polyvinylidene fluoride with crystal form II, In: Journal of Polymer Science Part-B Polymer Physics, 1973, vol. 11, issue 8, pp. 1503-1533.

[28] Teyssedre, G., Bernes, A. and Lacabanne, C., Influence of the crystalline phase on the molecular mobility of PVDF, In: Journal of Polymer Science Part-B Polymer Physics, 1993, vol. 31, pp. 2027-2034.

[29] Mohammadi, B., Yousefi, A. A. and Bellah, S. M., Effect of tensile strain rate and elongation on crystalline structure and piezoelectric properties of PVDF thin films, In: Polymer Testing, 2007, vol. 26, pp. 42-50.

[30] Ramos, M. M. D., Correia, H. M. G. and Lanceros-Mendez, S., Atomistic modeling of processes involved in poling of PVDF, In: Computational Materials Science, 2005, vol. 33, pp. 230-236.

[31] Salimi, A. and Yousefi, A. A., Analysis Method: FTIR studies of $\beta$-phase crystal formation in stretched PVDF films, In: Polymer Testing, 2003, vol. 22, issue 6, pp. 699-704.

[32] Ferreira, A., Costa, P., Carvalho, H., Nobrega, J. M., Sencadas, V. and Lanceros-Mendez, S., Extrusion of poly(vinylidene fluoride) filaments: effect of the processing conditions and conductive inner core on the electroactive phase content and mechanical properties, In: Journal of Polymer Research, 2011, vol. 18, issue 6, pp. 1653-1658.

[33] Silva, A. B., Wisniewski, C., Esteves, J. V. A. and Gregorio, R., Effect of drawing on the crystal-amorphous interphase, remanent polarization and dielectric properties of $\alpha-P V D F$ films, In: Ferroelectrics, 2011, vol. 413, issue 1, pp. 220-230.

[34] Soin, N., Shah, T. H., Anand, S. C., Geng, J., Pornwannachai, W., Mandal, P., Reid, D., Sharma, S., Hadimani, R. L., Bayramol, D. V. and Siores, E., Novel "3-D spacer" all fibre piezoelectric textiles for energy harvesting applications, In: Energy \& Environmental Science, 2014, vol. 7, issue 5, pp. 1670-1679.

\section{Authors:}

\section{Dr. DERMAN VATANSEVER BAYRAMOL}

Namık Kemal University

Corlu Faculty of Engineering, Department of Textile Engineering

59860, Corlu-Tekirdag-TURKEY

e-mail: dvbayramol@nku.edu.tr; dermanvs@gmail.com 


\section{Fabric with silver thread role in the control of bacterial contamination in critically ill patients}

Țesături cu fir de argint având rol de control al contaminării bacteriene la pacienții în stare critică

Argintul are o istorie lungă și controversată și este utilizat pentru proprietățile sale antibacteriene în domeniul îngrijirii sănătății umane. A fost utilizat în: purificarea apei, îngrijirea rănilor, protezele osoase, intervențiile chirurgicale ortopedice reconstructive, dispozitivele cardiace, catetere, aparate chirurgicale, bandaje și textile. Avansarea biotehnologiei a permis încorporarea de argint ionizabil în produse textile și bandaje pentru utilizarea clinică, în scopul reducerii riscului infecțiilor nosocomiale și pentru igiena personală. Acțiunea antimicrobiană a compușilor de argint este proporțională cu ionul de argint bioactiv ( $\mathrm{Ag} \mathrm{(+))} \mathrm{eliberat} \mathrm{și} \mathrm{disponibilitatea} \mathrm{acestuia} \mathrm{de} \mathrm{a} \mathrm{interacționa} \mathrm{cu} \mathrm{membranele} \mathrm{celulare} \mathrm{bacteriene}$ sau fungice. Argintul metalic și compuși ai argintului anorganici ionizează în prezența apei, fluidelor corporale sau exudatelor de țesut. lonul de argint este biologic activ și interactionează cu proteinele, resturile de aminoacizi, anionii liberi și receptorii pe membranele celulelor de mamifere și eucariote. Sensibilitatea bacteriană la argint este determinată genetic și se referă la nivelurile de absorbție de argint intracelular și capacitatea de a interacționa și a denatura sistemele enzimatice cheie într-un mod ireversibil. Argintul prezintă toxicitate redusă în corpul uman. Riscul minim poate fi din cauza expunerii clinice prin inhalare, ingestie, aplicare cutanată sau pe cale urologică sau hematogenă. Ingestia cronică sau inhalarea de preparate de argint (în special argint coloidal) poate duce la depunerea de metal argint/particule de argint sulfuroase în piele (argyria), ochi (argyrosis) și alte organe. Acestea nu sunt condiții care pun în pericol viața, dar sunt nedorite din punct de vedere cosmetic. Argintul este absorbit în corpul uman și intră în circulația sistemică, ca un complex de proteine care urmează să fie eliminat de către ficat și rinichi. Acest complex atenuează toxicitatea celulară a argintului și contribuie la repararea țesuturilor. Alergia la argint este o contraindicație pentru utilizarea argintului în dispozitive medicale sau textile antibacteriene.

Cuvinte-cheie: argint, antibacterian, clinic, particule, toxicitate, dispozitive medicale textile

\section{Fabric with silver thread role in the control of bacterial contamination in critically ill patients}

Silver has an intriguing, long history used for its antibiotic properties in human health care. It has been used in water purification, wound care, bone prostheses, reconstructive orthopaedic surgery, cardiac devices, catheters and surgical appliances, dressings and textiles. Advancing biotechnology has enabled incorporation of ionizable silver into fabrics, textiles and dressings for clinical use to reduce the risk of nosocomial infections and for personal hygiene. The antimicrobial action of silver is proportional to the bioactive silver ion $(A g(+))$ released and its availability to interact with bacterial or fungal cell membranes. Silver metal and inorganic silver compounds ionize in the presence of water, body fluids or tissue exudates. The silver ion is biologically active and interacts with proteins, amino acid residues, free anions and receptors on mammalian and eukaryotic cell membranes. Bacterial sensitivity to silver is genetically determined and relates to the levels of intracellular silver uptake and its ability to interact and irreversibly denature key enzyme systems. Silver exhibits low toxicity in the human body. Minimal risk is expected due to clinical exposure by inhalation, ingestion, dermal application or through the urological or haematogenous route. Chronic ingestion or inhalation of silver preparations (especially colloidal silver) can lead to deposition of silver metal/silver sulphide particles in the skin (argyria), eye (argyrosis) and other organs. These are not life-threatening conditions but cosmetically undesirable. Silver is absorbed into the human body and enters the systemic circulation as a protein complex to be eliminated by the liver and kidneys. This complex mitigates the cellular toxicity of silver and contributes to tissue repair. Silver allergy is a known contraindication for using silver in medical devices or antibiotic textiles.

Keywords: silver, antibacterial, clinical, particles, toxicity, textile medical devices

\section{INTRODUCTION}

Silver is a white metallic element found in many parts of the world in soil and rocks, fresh and salt water and in the atmosphere. Silver is the 63 most abundant element in the Earth's crust and is found naturally as the native metal or in numerous complexes with zinc, copper, mercury, etc. silver has a fascinating history in the treatment of human diseases including epilepsy, venereal diseases, cholera and wound infections. For centuries it has been observed that silver threads used in surgical sutures and silver foils used for wounds seemed to speed healing and tissue repair. Several metals had antibiotic effect but this discovery of the antibacterial properties of silver is due to Carl von Nagel in 1893 which introduced the concept of "oligodynamic action". Silver has an important contribution in elucidating radiography or a pathologic diagnosis; radiographic films contain $40 \%$ silver, which is why radiologists are prone to silver poisoning. 
Silver materials may be found in the form of:

- Dressings - on one side or both sides thereof (elemental silver or silver Nano crystals)

- Textiles - plain silver or silver compounds within the entire fabric or only in some parts of it.

The use of silver in textiles as a protection against bacteria and fungal infections (such as Tinea pedis) is located within a new comparative and expanding growth area at the moment. There is recognition of the increasingly large silver textile as these are useful in controlling infections especially in elderly and immune-compromised patients who are at risk of being infected with MRSA or other fatal pathogens.

Silver in the human body is found in a very small amount in the blood and tissues $(<2.3$ micro $\mathrm{g} / \mathrm{L}$ ). Silver absorbed into the body is metabolized in bone and soft tissues. Silver measurements in the blood (argyraemie) and urine are useful indicators of human silver exposure from any source [1-3].

How does it work? In its basic form, metallic silver can not have bactericidal action. To become bactericide, silver atoms ( $\mathrm{Ag} 0)$ must lose an electron and become positively charged $(\mathrm{Ag}+)$. Silver ionizes in the air but in the presence of an aqueous medium such as an exudate this process happens more pronounced and faster. Silver ions bind to the bacterial membrane, penetrating into the bacterial cell wall and breaking it, thus tearing the cell to death by affecting the enzymatic cell function and replication thereof [4].

Lately many technologies have sought to maximize ionization of I of silver or silver compounds and release a large amount of $\mathrm{Ag}$ ions for antibiotic action. Nanotechnology represents a major step in silver science, creating products with antibiotic function such as dressings or linens/sheets with silver which are designed for disinfection of infected wounds with moderately to severe bacterial colonization. Besides all this there are also silver-impregnated catheters designed to decrease the number of urinary tract infections in catheterized patients [5-7].

Metallic silver, silver sulfadiazine and other silver-containing products at the moment are used for antibiotic properties through: dressings, urinary catheters, intravascular insertions, cardiac devices, orthopedic products, water purification, textiles.

Today's technology is targeting production of silver dressings and textiles that release a sufficient amount of silver ions for an efficient antibiotic function without affecting patient health in any way nor medical staff exposure (figure 1).

Silver sulfadiazine is probably the most used antibiotic in the world based on silver for treating wounds.

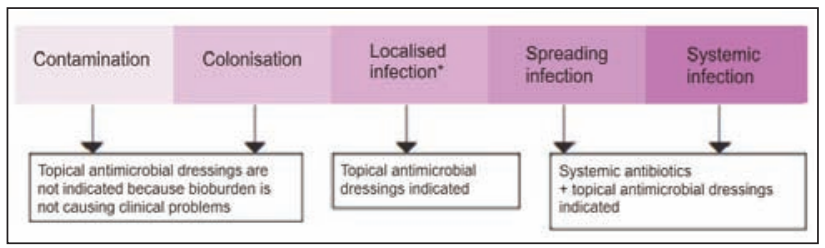

Fig. 1. When to implement antimicrobial dressings
Discovered in 1968, it has become very popular as a topical antibiotic for burns and wounds, especially those infected with Pseudomonas aeruginosa [8]. In the past 50 years is has been acquired a significant experience in terms of fabrics treated with silver, used in wound treatment. Effectiveness depends on the textile antibiotic binding molecules fiber surface biocides. In the case of silver, the effectiveness is directly proportional to the amount of fiber and silver ionization potential with the skin contact. Molecular mechanisms are complex but are believed to be involved in bioactive molecules found on the surface of the fiber and kinetic ions in the presence of exudate or metabolites given by the infection itself (enzymes, toxins).

All types of silver (metal, colloidal, sulfadiazine, etc.) were used in the creation of these natural or synthetic textile fibers for medical products, textile clothing, hygiene products, linens. The chemistry of these compounds is well known, but recently it has appeared a new compound that has been introduced, $\mathrm{Ag}_{4} \mathrm{O}_{4}$ osmium (containing two monovalent ions and two trivalent silver ions in each molecule). The effectiveness of fiber that is inserted is shown in many studies. Apparently hydrophilic fibers treated with this product are resistant to sunlight and have excellent antibiotic properties against Gram positive and Gram negative.

The main considerations when it comes to textiles impregnated with silver:

- Type of fiber: durability, resistance to long skin contact, durability in the presence of skin secretions.

- Technology used: silver impregnation within the entire fiber surface or accumulated only in certain areas.

- Efficacy versus safety: the release of silver ions will be sufficient for therapy or prophylaxis against pathogens but is insufficient in predicting an imbalance in skin infections. Only Silver ions have antibiotic properties; therefore attention to the use of the products and their release.

Textiles and impregnated dressings using silver are still in their early stage and we expect in the near future to make important discoveries related to Silver. Even if you want a quick release of silver from the bacteriological point of view it is preferable that this be done slowly in a certain number of days. This will prevent possible toxicity of silver date.

Although some bacteria can develop resistance to silver, scientists do not take this very seriously because studies show that most products that release silver ions are effective against MRSA and VRE action (vancomycin resistant enterococci).

A number of studies have shown that silver materials are associated with factors that may be beneficial in terms of cost-efficiency chronically hospitalized patients:

- Reducing the healing time of wounds [9].

- Reduced length of hospitalization.

- Low frequency of dressing change/textiles [10].

- Fewer MRSA bacteremia - infections due to MRSA wound/wounds/bedsores [11]. 


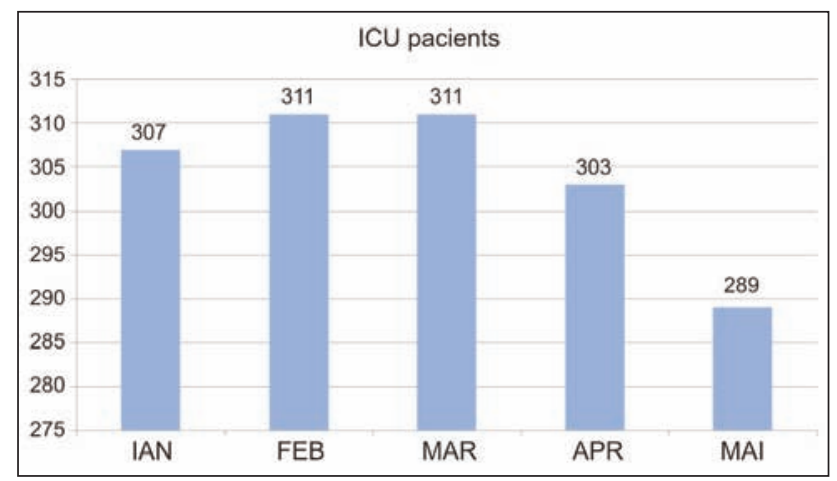

Fig. 2. Number of ICU patients

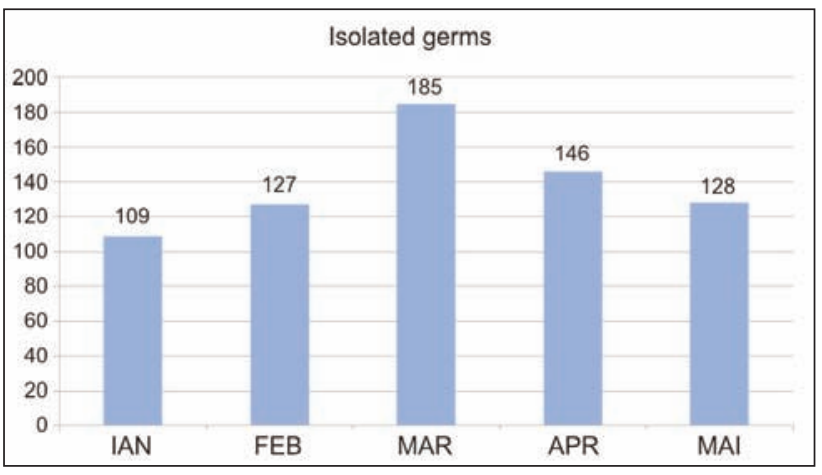

Fig. 3. Isolated germs - totally each month

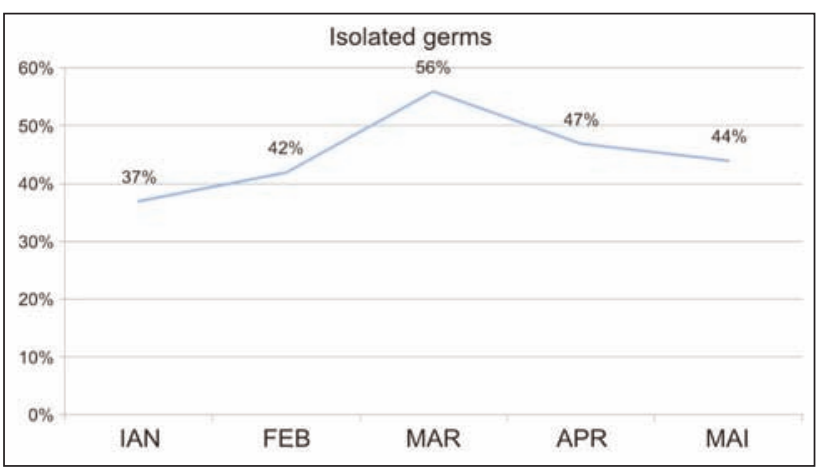

Fig. 4. Isolated germs - totally each month

Research in this area and the clinical efficiency of silver and silver materials is continuously developing. In the future we need to discover more about clarification of the relationship between the type of material used and bioavailability of silver; how money affects clinical performance; cost-effectiveness; development of less invasive tests for the discovery of infection, etc.

In Bucharest Emergency University Hospital, Department of Anesthesiology and Intensive Care, we tried to see the effects of using textiles but also dressings impregnated with Silver on infected in or out patients of the hospital in January-May 2016 with the introduction of impregnated silver textiles in March 2016 versus no silver textiles from 1 January 2016-1 march 2016. The numbers of patients admitted to ICU ward this period were around 300 each month (figure 2).

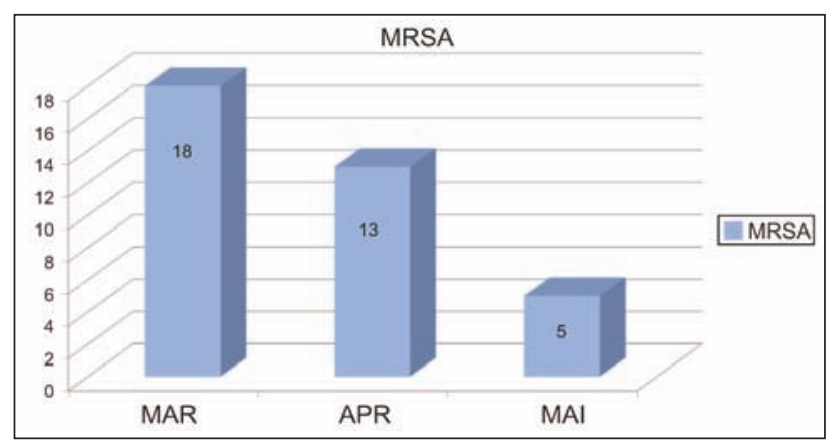

Fig. 5. Isolated MRSA cultures for March, April, May

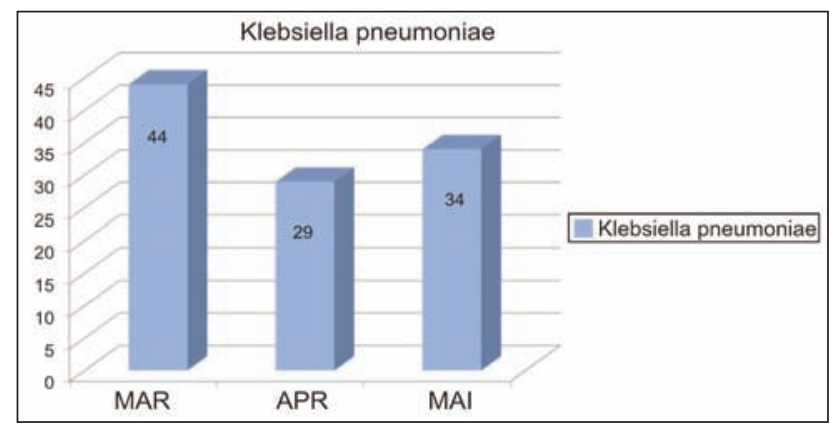

Fig. 6. Isolated Klebsiella cultures for March, April, May

Laboratory isolates of clinical specimens of all patients are: in January $37 \%$, February $42 \%$, March $56 \%$, April $47 \%$, May $44 \%$ (figure 3, 4). Observe a maximum number of isolates within January-March followed by a downward trajectory apparently after introducing textiles Silver.

\section{RESULTS}

In terms of the type of germ, MRSA was isolated in 63 cases out of a total of 1521 patients. Maximum of MRSA strains was found in February with 19 cases followed a downward trajectory in March of 18 cases, 13 cases in April and 5 cases in May (figure 5).

Apparently on Klebsiella pneumoniae we didn't notice any effect because the isolates were a total of about 30 each month (figure 6).

\section{CONCLUSIONS}

So far we can say that textiles, linens and dressings with Silver have a possible influence on infected patients hospitalized in the ICU, even if the downward trend thereof may be awarded-full of new methods introduced, this depending on many factors, such as disinfect wards, medical staff hygiene, etc. It is an observational study that will continue with investigations on the total number of isolates, the type of bacteria that silver impregnation may take effect or not. The importance of using in the medical hospital practice silver textiles and linen bandages is expressed by the way, according to the law currently in force in Romania (harmonized 2006 with EU standards), the rise to civil liability in the event of allegations of medical malpractice issued following the damages caused by nosocomial infection patients. 
In these situations the responsibility lies with the health institution (hospital, clinic or doctor's office) which will have to pay patients harmed due their monies in the form of material and moral damages, civil courts amounts established by final and irrevocable court decision. Since health institution has the legal obligation to implement a plan of surveillance, prevention and control of nosocomial infections it is natural to her task to undamaged the patients who suffer from nosocomial infections acquired during hospitalization. In any contract for liability insurance institutional hospital it is stipulated that the insurance company will not pay if the hospital violated a legal regulation of any kind. For this reason it often happens that the damages to the patient are entitled to be paid from the funds even health institution in question $[12,13,14]$.

Experience processes conducted in civilian courts Romanian, from 2006 until today, show that the damage caused to a patient as a result of nosocomial infections is perfectly possible that it gets in the end the judges financial compensation in the form of damages several hundreds of thousands of Euros. It is not difficult to understand that 3-4 such cases occurred during a year in the same hospital can mean in fact that bankruptcy financial health institutions. That's why any hospital management to take all possible measures to prevent nosocomial infections is a priority in medical practice and hospital use textiles, linen and dressing with silver, in this context, a wise decision [15].

\section{BIBLIOGRAPHY}

[1] Lansdown A.B.G., Silver I: its antibacterial properties and mechanism of action, In: J Wound Care 2002; 11(4): pp. 125-130.

[2] Lansdown A.B.G., Silver, in Chemistry: Foundation and Application, In: Ed. J. J. Lagowski, Thomas Gale, MacMillan reference, Farmington Mills, MI, 2004, Ch.4, p.126

[3] Lansdown A.B.G., Silver in health care: antimicrobial effects and safety in use, In: Curr Probl Dermatol. 2006, 33, pp. 17-34. Review

[4] Parsons D., Bowler P.G., Myles V., Jones S., Silver antimicrobial dressings in wound management: a comparison of antibacterial, physical, and chemical characteristics, In: Wounds 2005, 17(8), pp. 222-232.

[5] R.E. Burrell, A scientific perspective on the use of topical silver preparations, In: Ostomy Wound Manage, 2003, 49 (Suppl. 5A), p. 19.

[6] World Union of Wound Healing Societies (WUWHS), Principles of best practice: Wound infection in clinical practice. An international consensus, In: London: MEP Ltd, 2008. Available from www.woundsinternational.com

[7] Lipsky B.A., Hoey C., Topical antimicrobial therapy for treating chronic wounds, Clinical Practice 2009, 49, pp. 1541-1549.

[8] E. J. L. Lowbury, Infection associated with burns, In: Postgrad. Med. J., 1972, 48, p. 338.

[9] Muangman P., Pundee C., Opasanon S., Muangman S., A prospective, randomized trial of silver containing Hydrofiber dressing versus $1 \%$ silver sulfadiazine for the treatment of partial thickness burn, In: Int Wound J 2010 , 7(4), pp. 271-76.

[10] Caruso D.M., Foster K.N., Blome-Eberwein S.A., et al., Randomized clinical study of Hydrofiber dressing with silver or silver sulfadiazine in the management of partial thickness burns, J Burn Care Res 2006; 27(3), pp. $298-309$.

[11] Newton H., Reducing MRSA bacteraemias associated with wounds, In: Wounds UK 2010, 6(1), pp. 56-65.

[12] A. Nanu, (2013) Malpraxisul medical - 7 instrucțiuni de siguranță, Ediția a II-a, ISBN 978-973-0-15017-9.

[13] A. Nanu, D. Georgescu, V. Voicu, B. Ioan, Locul și relevanța prevederilor legale în contextul practicii medicale din România, In: Revista Română de Bioetică, vol. 9, nr. 4, octombrie-decembrie, 2011.

[14] A. Nanu, D. Georgescu, D. Bulgaru, M. Berteanu, C. Rădulescu, Using the International Classification of Functioning, Disability and Health in assessing moral damages, In: Romanian Journal of Legal Medicine, vol. 20 , Issue 1, March 2012.

[15] S. Pituru, S. Vladareanu, S. Paun, A. Nanu, Malpractice and professional liability of medical personnel, FARMACIA, 2015, vol. 63, 2

\section{Authors:}

\section{Dr. Ovidiu N. Peneș}

Universitatea de Medicină și Farmacie Carol Davila București, Facultatea de Medicină, Clinica ATI I Spitalul Universitar de Urgență București

\section{Dr. Andrei Mihai Neagu}

Clinica ATI I Spitalul Universitar de Urgență București

Dr. Flavius Plața

Departamentul Control Epidemiologic, Spitalul Universitar de Urgență București

Dr. Silviu Dumitru Păun

Universitatea de Medicină și Farmacie Carol Davila București, Facultatea de Medicină

\section{Corresponding author:}

Dr. Ovidiu N. Peneș

e-mail: office@DrOvidiuPenes.ro 


\title{
Factors affect the carrying capacity of non-woven shopping bags
}

\section{REZUMAT - ABSTRACT}

\section{Factori care afectează capacitatea de încărcare a pungilor de cumpărături din nețesute}

\begin{abstract}
Convingerea că a merge la cumpărături cu pungi de cumpărături refolosibile este o alegere conștientă importantă din punct de vedere ecologic și social este din ce în ce mai populară. Multe țări au luat măsuri pentru interzicerea comercializării gratuite a pungilor de plastic de unică folosință. Pungile de cumpărături din nețesute au fost utilizate pe scară largă de către consumatori pentru a transporta produse alimentare și bunuri cumpărate, după interzicerea distribuirii de pungi de plastic pentru cumpărături, gratuite în China, începând cu data de 1 iunie 2008. Capacitatea de încărcare este un factor important care afectează timpii de reutilizare a pungilor de cumpărături din nețesute. În această lucrare, a fost evaluată capacitatea de încărcare cu ajutorul testelor de agățare. Rezultatele au arătat că mânerul și cusătura de la mâner, precum și punga în sine au cedat mai rapid în comparație cu alte părți în timpul testelor. Aceștia au fost cei mai importanți doi factori care afectează capacitatea de încărcare. Tehnologia de fixare termică a fost mai bună decât tehnologia de coasere, deoarece aceasta a cauzat o deteriorare mai mică a tăierii pe materialul textil în timpul confecționării pungilor de cumpărături din nețesute. Creșterea lățimii mânerului și echivalentul-gram greutate al nețesutului pot îmbunătăți capacitatea de încărcare a pungilor de cumpărături.
\end{abstract}

Cuvinte-cheie: capacitate de încărcare, pungi de cumpărături nețesute, factori de efect, test de agățare, eco-performanță

\section{Factors affect the carrying capacity of non-woven shopping bags}

The belief that shopping with reusable shopping bags is an important environmental and socially conscious choice has gained prevalence. Many countries have taken steps to ban free retail use of disposable plastic bags. Non-woven shopping bags were widely used by consumers to carry purchased groceries and goods after prohibiting the distribution of free plastic shopping bags in China since June 1, 2008. Carrying capacity is an important factor that affects the reusable times of non-woven shopping bags. In this paper, the carrying capacity was evaluated with hanging tests. The results showed that handle belt and the seam jointing handle belt and bag body fatigued faster than other parts during tests. They were the most important two factors that affect the carrying capacity. Thermal attachment technology was better than sewing technology as it caused less cutting damages on the fabric during the production of non-woven shopping bags. Increasing the width of handle belts and the gram weight of non-woven fabric can improve the carrying capacity of shopping bags.

Keywords: carrying capacity, non-woven shopping bags, effect factors, hanging test, eco-performance

\section{INTRODUCTION}

Shopping bags are produced to carry groceries and goods from the shop to the home. There are different types of shopping bags available to cater for the shopping needs of consumers. A variety of raw materials and technologies are employed to manufacture them, the most popular of those are plastic, paper, non-woven and woven bags. Shopping bags have generally been categorized as disposable (i.e. single use) or reusable [1]. Disposable shopping bag, mainly made of plastic, is a symbol of the throw-away society. Usage of free plastic bags at supermarkets is a repetitive type of behavior in daily life, which is acknowledged as a habit [2-3]. According to the estimate of the Global Warming White Paper, over 300 plastic bags per person are consumed every year [4]. As concerns about pollution and climate change become more mainstream, the belief that people use fewer plastic shopping bags is an important environmental and socially conscious choice has gained prevalence [5].
Therefore, the free use of plastic shopping bags has become one of the most important issues to be addressed by the competent authorities. Several governments have taken initiatives for the limitation of the use of plastic shopping bags. The plastic shopping bag fee has become legally mandatory in many countries such as China, India, Mexico, and cities of Australia, USA, Canada, etc. [6]. For example, on June 1, 2008, China instituted a nationwide regulation prohibiting the distribution of free plastic shopping bags. Instead, consumers had to pay a small fee at checkout. By 2011, 28 U.S. cities, including New York and San Francisco, had enacted some form of ban, fee, or other regulation on the use of "thin-film" disposable shopping bags. In September 2014, California became the first state to ban single-use plastic shopping bags [7]. As an alternative, non-woven bags made of spun-bonded polypropylene (PP) are most commonly used for shopping purposes in recent years [8]. The non-woven PP shopping bag is stronger and more durable. They are intended to be reused many times. Generally, non-woven PP shopping 


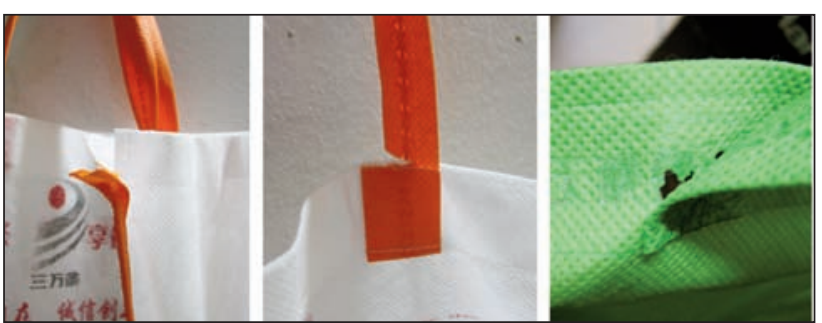

Fig. 1. Break forms of non-woven shopping bags

bags are expected to be reused at least 20 times and they break down when they are exposed in sunshine or buried in soil for several months.

The shopping bag therefore needs to provide a convenient option for the consumer to carry or transport the shopping home, but at the same time be robust enough to hold a certain quantity of groceries and goods. However, the carrying capacity is not labeled on the bags as there is no testing method for the carrying capacity of non-woven shopping bags. Many bags are not reusable as they are not stability enough and easily broken in use (figure 1). A questionnaire survey showed that carrying capacity and reusable times of non-woven shopping bags gained the most concern from customers [9]. In fact, carrying capacity is the important factor that affects reusable times and the eco-performance of non-woven shopping bags. In this paper, the carrying capacity of nonwoven shopping bags was tested by a self-designed instrument and factors that affect the carrying capacity were discussed.

\section{MATERIALS AND METHODS}

Two kinds of commonly used non-woven shopping bags were selected for this research. The shopping bags were made of polypropylene (PP) non-woven fabric which produced by spun-bonded technology. The technologies used to produce the shopping bags were thread sewing and thermal attachment with ultrasonic wave. The physical properties of the shopping bags are listed in table 1.

Shopping bags filled with purchased groceries show a wave motion locus when consumers carry them from shop to home. A hanging instrument was designed to imitate the vibration movement in order to test the carrying capacity of the non-woven shopping bags. The schematic of the instrument can be seen from figure 2 . The frequency of the reciprocating motion is $130 \pm 1$ times per minute and the amplitude is $30 \pm 2 \mathrm{~mm}$, refers to the standard of carrying

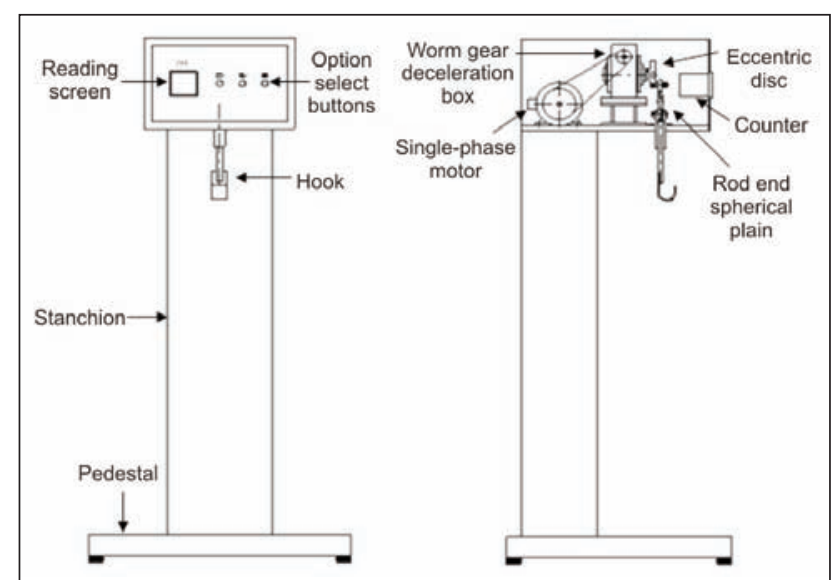

Fig. 2. The front and side schematic of the instrument

capacity testing of plastic shopping bags (GB/T 21661-2008 Plastic shopping bags). One testing cycle includes 3600 times reciprocating motion.

Glass balls with uniform shape and density were selected as simulants for groceries. The diameter of the glass ball was one centimeter. The tested nonwoven shopping bags were filled with the glass balls to approximately the two third of their full volumes. The weight of NWB1 (filled with glass balls) was $8 \mathrm{~kg}$, equaled to that of NWB2. Then they were hanged in the hook (figure 3 ) and tested through reciprocating motion after starting the instrument.

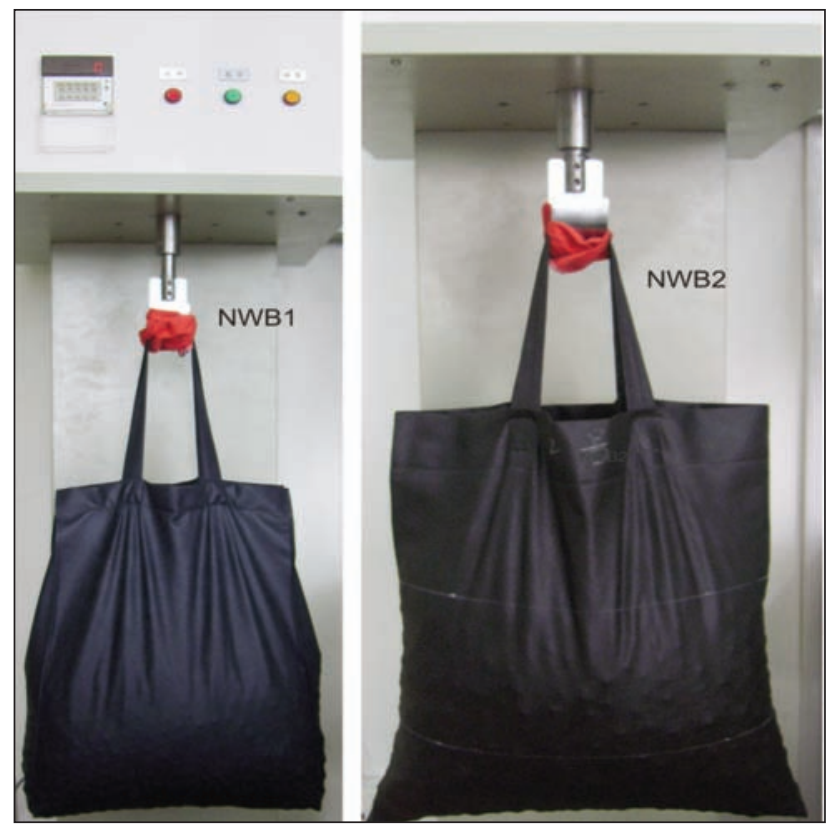

Fig. 3. Hanging method of the tested bags

\begin{tabular}{|c|c|c|c|}
\hline \multicolumn{4}{|c|}{ PHYSICAL PROPERTIES OF THE TESTED NON-WOVEN SHOPPING BAGS } \\
\hline Number & Produce technologies & Fabric weight $\mathbf{( g / \mathbf { m } ^ { 2 } )}$ & Size (cm) \\
\hline NWB1 & Thread sewing & 65 & $\left.40(\mathrm{~L})^{*} 32(\mathrm{~W})\right)^{\star} 8(\mathrm{D})$ \\
\hline NWB2 & Thermal attachment & 75 & $25(\mathrm{~L}) * 45(\mathrm{~W})$ \\
\hline
\end{tabular}

Note: $L$ means length, $W$ means width and $D$ means depth. 
When the reciprocating motion comes to $3600^{*} n(n=$ $1,2,3 \ldots)$ times, there will be a break. The testing started again after five minutes. The instrument will stop when the tested bag was broken and the times of reciprocating motion can be read from the reading screen. Five non-woven shopping bags of each kind were tested separately.

\section{RESULTS AND DISCUSSION}

During the testing process, the width of handle belts of the two kinds of non-woven shopping bags changed significantly. This can be seen from figure 4 and figure 5 .

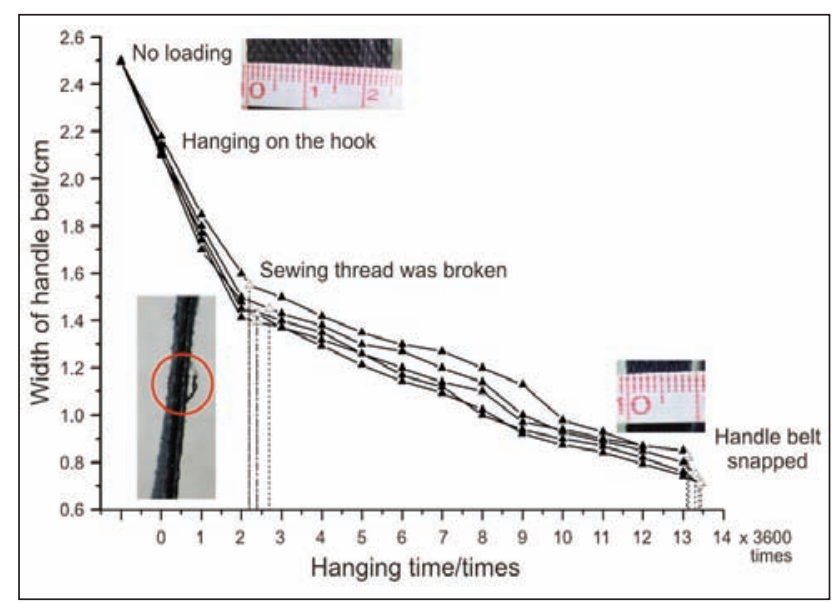

Fig. 4. Hanging times and width of handle belts of NWB1

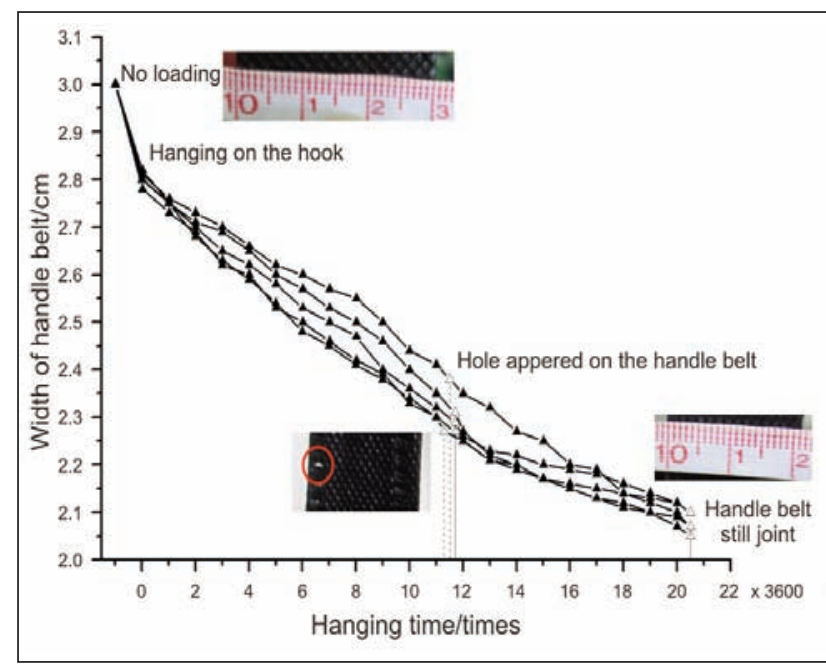

Fig. 5. Hanging times and width of handle belts of NWB2

From figure 4 it can be seen that with the increasing of hanging times, the width of handle belts decreased gradually. Before the glass balls loaded in the shopping bag, the width was $2.5 \mathrm{~cm}$. After the shopping bag was hanged in the hook with $8 \mathrm{~kg}$ glass balls, the width decreased to $2.1 \mathrm{~cm}$. The sewing thread on the handle belts was broken when the hanging times passed 7200 times. The handle belts snapped soon after a crack appeared on the handle belts when the hanging times passed 46800 times (i.e. 13 testing cycles). Figure 5 shows the hanging test process of
NWB2. The width of handle belts decreased from $3.0 \mathrm{~cm}$ to $2.8 \mathrm{~cm}$ when $8 \mathrm{~kg}$ glass balls were loaded. Holes appeared on the handle belts when the hanging times passed 39600 times (i.e. 11 testing cycles). However, after reciprocating hanging 72000 times (i.e. 20 testing cycles), the handle belts still not snapped though the width decreased to approximately $2.1 \mathrm{~cm}$.

According to the results of the hanging tests, another three more non-woven shopping bags of each kind were selected for hanging tests. They were hanged 13 testing cycles (NWB1) and 20 testing cycles (NWB2) respectively. All the six non-woven shopping bags were not damaged after the hanging test. Than the tensile strength (TS) of handle belts (TS-HB), vertical fabric of bag body (TS-VF), crosswise fabric of bag body (TS-CF), seams jointing handle belts and bag body (TS-SHB) and seam on the bag body (TS-SBB) were tested according to ISO 9073-3:1989 Textiles - Test methods for nonwovens - Part 3: Determination of tensile strength and elongation. Tear resistance (TR) of vertical fabric of bag body (TR-VF) and crosswise fabric of bag body (TR-CF) were tested according to ISO 9073-4:1997 Textiles Test methods for nonwovens - Part 4: Determination of tear resistance. The results can be seen from figure 6 and figure 7 .

From figure 6 and figure 7 it can be seen that all the tensile strength and tear resistance of the tested nonwoven shopping bags decreased after hanging tests. For NWB1, TS-HB decreased the most, by approximately $38.1 \%$, followed by TS-SHB $(32.4 \%)$ and TSVF $(21.6 \%)$. TS-CF decreased the least $(7.8 \%)$. For NWB2, TS-SHB, TS-HB and TS-VF were also the three items that decreased larger than any other parts. Their descent ranges were $23.2 \%, 17.9 \%$ and $17.0 \%$, respectively. TS-SBB decreased the least $(4.9 \%)$ though it was the largest strength.

The force analysis of hanging tested non-woven shopping bags is shown in figure 8 . When non-woven shopping bags were hanged in the hook of the instrument for hanging tests with $8 \mathrm{~kg}$ glass balls loaded,

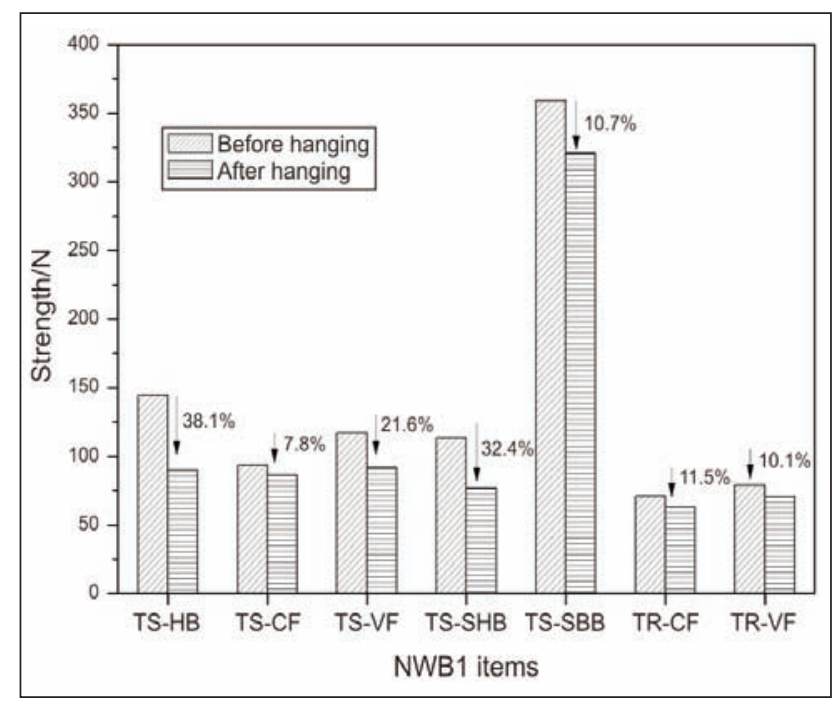

Fig. 6. Strengths test results of NWB1 


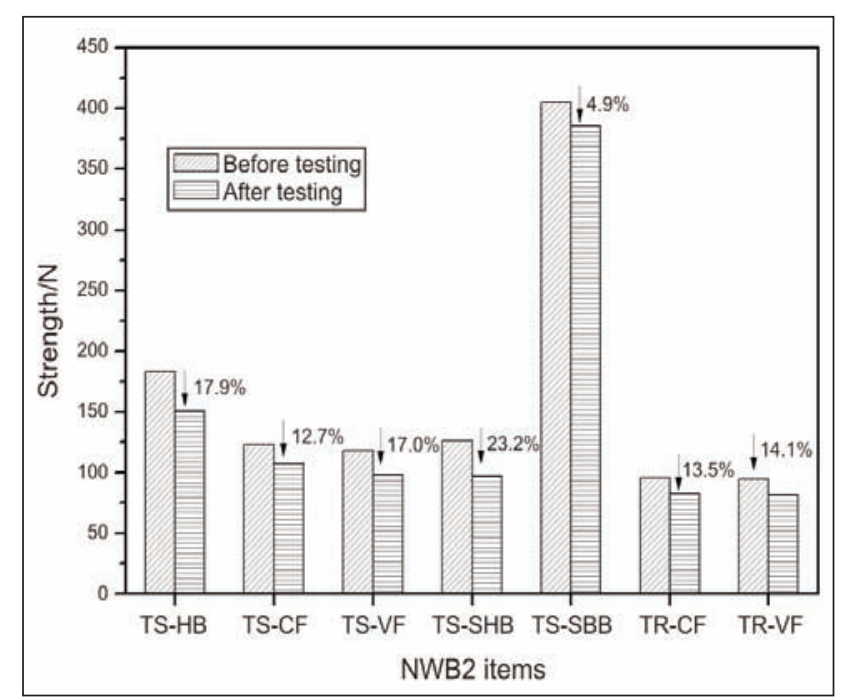

Fig. 7. Strengths test results of NWB2

the entire tensile load caused by gravity was applied on the handle belts. There were stress concentrations on the seams jointing handle belts and bag body. The handle belts and seams jointing handle belts and bag body fatigue fast during reciprocating motion. Their tensile strength decreased largely as a result. Therefore, descent ranges of TS-HB and TS-SHB were larger than other parts for the two kinds of non-woven shopping bags. What's more, the reciprocating motion was in vertical direction, so the vertical fabric of bag body also bears considerable tensile load and TS-VF reduced largely.

The handle belts of NWB1 were sewed with thread. Generally, the extensibility of the sewing thread and handle belts were different. In this case, the handle belts and the stitch were elongated by the loaded glass balls during hanging test. The sewing thread broke in advance when the elongation of the handle belts exceeded the maximum elongation of the sewing thread (see figure 4). Besides, sewing may damaged the non-woven fabric of the handle belts if the needle cut off the fibers. Thermal attachment is a new high-efficiency technology in non-woven shopping bag production. Cut pieces of non-woven fabrics are attached with ultrasonic wave to produce a nonwoven shopping bag. There are uniform bounding points instead of stiches on the fabric. This can avoid the cutting damage on the shopping bags. However, the bonding temperature must be controlled in a suitable range in order to avoid the bounding points melt into holes. Generally, when the bounding points are exposed continuous tensile strength, they will crack eventually (figure 5).

The width also has considerable effect on the durability of the handle belts. The wider of the handle belts, the more durable. The testing results of the two kinds of handle belts supported this (figure 4 and figure 5). Besides, it is more convenient for customers to carry groceries using non-woven shopping bags with wider handle belts as their hands feel less tighten. However, wider handle belts consume more non-woven fabric causing the increasing of production

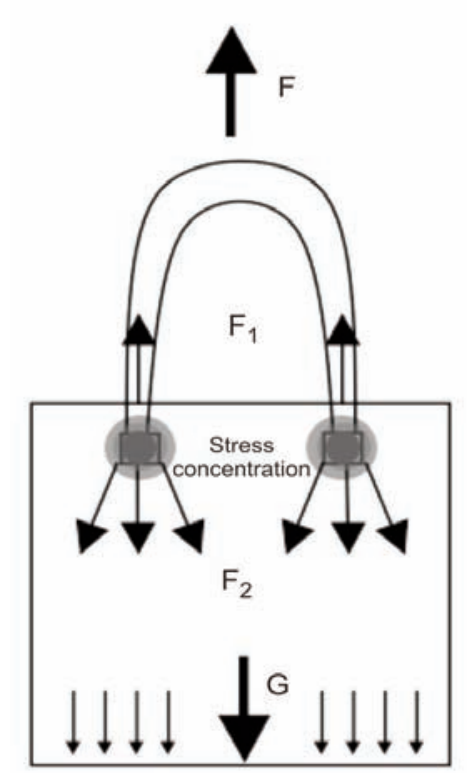

Fig. 8. Force analysis of the hanging tested non-woven shopping bags

cost. It was pointed out that $3.0 \sim 3.5 \mathrm{~cm}$ was the most reasonable width considering the function and production costs of handle belts. Non-woven shopping bags produced with heavier fabric are more durable in use. For example, tensile strengths and tear resistances of NWB2 were larger than that of NWB1 even though NWB2 were reciprocating hanged much more times than NWB1. The gram weight of non-woven fabric for shopping bags production is generally between $50 \mathrm{~g} / \mathrm{m}^{2}$ and $100 \mathrm{~g} / \mathrm{m}^{2}$. A survey showed that $75 \sim 80 \mathrm{~g} / \mathrm{m}^{2}$ was mostly selected as it not only satisfied the reuse requirement but also saved production costs.

\section{CONCLUSIONS}

Attention to environmental protection concerns has been steadily increasing in the popular sphere. People can help protect the environment by adopting a green lifestyle. In particular, education about environmental protection issues and policies designed to encourage "green" behaviors have been taken to promote the adoption of reusable shopping bags. In China, non-woven shopping bags were widely used to carry purchased groceries and goods after prohibiting the distribution of free plastic shopping bags. Carrying capacity is the important factor that affect the reusable times of non-woven shopping bags. This paper encompasses the study of testing method for the carrying capacity of non-woven shopping bags. The testing results showed that handle belt and the seam jointing handle belt and bag body fatigued faster as they bear more load than other parts during hanging tests. They were the most important two factors that limit the carrying capacity. It is meaningful to pay more attention to these two components in designing and producing non-woven shopping bags. Thermal attachment technology was better than sewing technology as it caused less cutting damages 
on the fabric during the production of non-woven shopping bags. Increasing the width of handle belts and the gram weight of non-woven fabric can improve the carrying capacity and shopping bags will be reused more times.

Evaluating the testing method and effect factors of carrying capacity is meaningful for the producing and using of non-woven shopping bags. Nevertheless, it is recognized that this provides a partial overview of usability of non-woven shopping bags. The overall systematic research on the eco-performance (e.g., carbon footprint, water footprint) of non-woven shop- ping bags has significant importance. It should gain more attention in future research.

\section{Acknowledgements}

The authors are grateful to the Zhejiang Provincial Natural Science Foundation for providing funding supports to this research through project LQ16G030012, to Zhejiang Sci-Tech University for providing funding supports to this research through project "Zhejiang Sci-Tech University Scientific Research Foundation (15072022-Y)" and "Zhejiang Top Priority Discipline of Textile Science and Engineering (2013YBZX03)". The authors are also grateful to reviewers for their constructive, detailed and responsible comments on the manuscript.

\title{
BIBLIOGRAPHY
}

[1] Muthu S.S., Li Y., Assessment of environmental impact by grocery shopping bags: An eco-functional approach, Springer Verlag, Singapore, 2013.

[2] Aarts H., Dijksterhuis A., Habits as knowledge structures: automaticity in goal- directed behavior. In: Journal of Personality and Social Psychology. 2000, vol. 78, no. 1, pp. 53-63.

[3] Ouellette J.A., Wood W., Habit and intention in everyday life: the multiple pro- cesses by which past behavior predicts future behavior. In: Psychological Bulletin. 1998, vol. 124, no. 1, pp. 54-74.

[4] Ohtomo S., Ohnuma S., Psychological interventional approach for reduce resource consumption: Reducing plastic bag usage at supermarkets. In: Resources, Conservation and Recycling. 2014, vol. 84, no. 2, pp. 57-65.

[5] http://iems.ust.hk/wp-content/uploads/2014/09/IEMS-Thought-Leadership-Brief_no2.pdf

[6] http://www.nytimes.com/2012/02/09/business/energy-environment/should-plastic-bags-be-banned.html

[7] http://www.npr.org/blogs/thetwo-way/2014/09/30/352774915/ban-on-single-use-plastic-bags-is-enacted-incalifornia

[8] Muthu S.S., Li Y., Hu J.Y., Mok P.Y., Carbon footprint of shopping (grocery) bags in China, Hong Kong and India. In: Atmospheric Environment, 2011, vol. 45, no. 2, pp. 469-475.

[9] Wang L.L., Reach on the performance and evaluation methods of non-woven eco-shopping bags, Master of Science Thesis, Donghua University, 2010.

\section{Authors:}

\author{
LAI-LI WANG ${ }^{1,2}$ \\ XUE-MEI DING 3 \\ XIONG-YING WU4 \\ ${ }^{1}$ National Engineering Laboratory for Textile Fiber Materials and Processing Technology \\ Zhejiang Sci-Tech University, Hangzhou 310018, China \\ ${ }^{2}$ Zhejiang Sci-Tech University (Engineering Research Center of Clothing of Zhejiang Province) \\ Hangzhou 310018, China \\ ${ }^{3}$ Fashion Institute of Design, Donghua University, Shanghai, 200051, China \\ ${ }^{4}$ Shanghai Entry-exit Inspection and Quarantine Bureau, Shanghai, 200135, China
}

\section{Corresponding author:}

LAI-LI WANG

wangll@zstu.edu.cn 


\title{
Innovative design and simulation of clothing products for children with atypical changes in conformation and posture
}

\section{REZUMAT - ABSTRACT}

\section{Design inovativ și simularea produselor de îmbrăcăminte pentru copiii cu modificări atipice ale conformației și ținutei}

\begin{abstract}
Lucrarea prezintă etapele de proiectare a produselor de îmbrăcăminte pentru copiii cu modificări atipice ale conformației și ținutei, simularea virtuală și modelarea pentru verificarea corp-produs. Tehnologia de proiectare este inovativa și permite obținerea unor modele personalizate prin metoda made-to-measure aplicată modelelor standardizate pentru toate grupele de vârstă ale copiilor, prin selectarea metodei corespunzătoare tipo-dimensiunii subiectului studiat. Numărul mare de date antropometrice existente și vizualizarea corpului virtual permit identificarea zonelor corpului care prezintă modificări ale conformației și ținutei și furnizează informații proiectantului și tehnicianului de modele, în scopul de a dezvolta produse adecvate în ceea ce privește funcționalitatea și estetica. Cu ajutorul software-ului de simulare Optitex 3D, modelarea simulărilor se realizează pe corp până la îndeplinirea gradului de conformitate a produsului proiectat.
\end{abstract}

Cuvinte-cheie: îmbrăcăminte pentru copii, modificări atipice, conformație, modele, simulare 3D

\section{Innovative design and simulation of clothing products for children with atypical changes in conformation and posture}

The paper presents the design stages of clothing products for children with atypical changes in conformation and posture and the virtual simulation and modeling for the body-product verification. The design technology is an innovative one that allows obtaining the customized patterns by made-to-measure method applied to standardized patterns for all age groups of children, selecting the one corresponding to the typo-dimension of studied subject. The large number of existing anthropometric data and viewing virtual body allows the identification of areas of the body that shows changes in conformation and posture and provides information to the designer and pattern technician in order to develop suitable products in terms of functionality and aesthetics. With the help of simulation software Optitex 3D simulations modeling is performed on the body until fulfillment of the compliance degree for the designed product.

Keywords: children's clothing, atypical changes, conformation, patterns, 3D simulation

\section{INTRODUCTION}

The anthropometric survey was developed by INCDTP, by using for measuring the mobile scan system "Anthroscan - Human Solutions", for children with bodies that deviate from normality, both in terms of size as circumferences, lengths and widths and as proportions and body postures.

The most common changes in conformation and posture are due to deficiencies in the back, legs, uneven disposition of body fat etc. These children represent a category of wearers for that clothing products designed based on anthropometric standards are not conformable, requiring the design of customized patterns that take into account the conformational changes of posture and special needs where appropriate. This is done with made-to-measure program, replacing the standardized anthropometric data with customized ones and then applying specific design algorithms.

\section{EXPERIMENTAL WORK}

Anthropometric data analysis undertaken by 3D scanning of areas with atypical changes in conformation and posture

For children with atypical changes in conformation and posture, it is not possible to use the virtual dummy because it cannot be parameterized proportionality in the limits of the body and cannot reproduce the deficiencies at spine or limbs level. Subsequently, the virtual body resulting from scanning is used for simulation and modeling of virtual clothing products. The importance of clothing products design and simulation for children with atypical changes in conformation and posture is a considerable one. Given the disproportionate body parts, they could not be included in production series and by wearing inappropriate products decreases physical and psychological comfort. A case study is illustrated in figure 1 , respectively a male child 8 years old and height of $134 \mathrm{~cm}$, on which a designed product - 


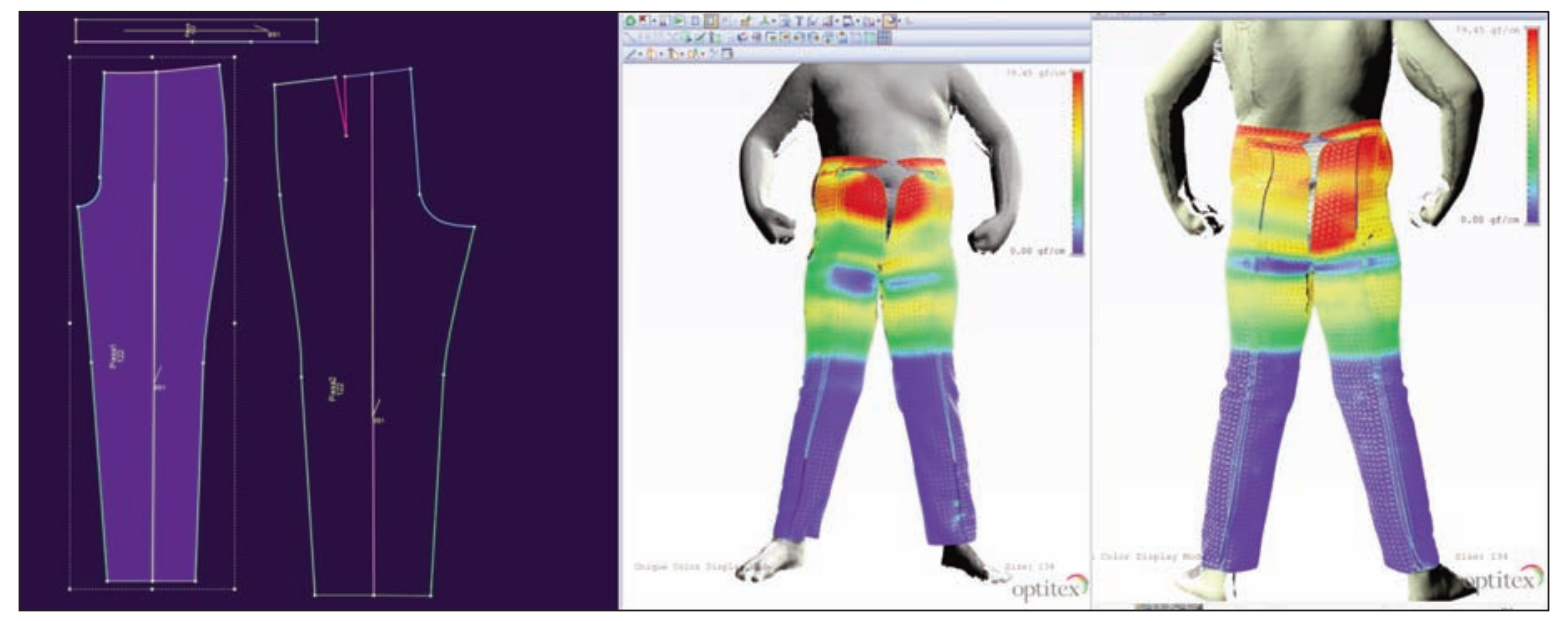

Fig. 1. Incorrect disposal on the body of standardized size trousers

trousers for boys was simulated based on anthropometric standard SR 13546/2012, corresponding to age and its height [1].

In this case the biggest change is in the abdomen level, creating disproportionality in the lower torso. It involves non-conformity in clothing products with waist support, especially in areas of the abdomen, hips and thighs, both in terms of dimensions and aesthetics. It was also observed the atypical position of the legs, with a deformity at the knees that affects the product draping on the body.

\section{Design of basic patterns for clothing products for children with atypical changes in conformation and posture}

A body with atypical changes in conformation and posture is a special case in terms of shape and size appropriate clothing product. Therefore, the proper method for its designing is the Made-to-Measure method. This uses the geometric method for patterns design based on primary and secondary dimensions taken directly from the scanned body.

At this stage of design, the research of atypical body changes intervenes and the development of design algorithms suitable for the type of change in conformation or posture.

The application of the methodology for the pattern design Made-to-measure, in the case of children with atypical change in conformation is due to uneven distribution of adipose tissue requires pre-established steps:

Step 1. Identify the area or areas with atypical changes in conformation and posture (figure 2).

Step 2. Fit the subject in an appropriate anthropometric standard sizes of gender, age and height; according to the statement, 8 years old, height $134.5 \mathrm{~cm}$. Thus, fit into the group "boys aged from 6 years to 8 years, $134 \mathrm{~cm}$ ".

Step 3. The type of clothing product that requires dimensional changes is pants [2]. Construct a personal table with anthropometric data necessary for trouser pattern design (table 1).

Step 4. Access the data base with patterns corresponding to the type of product to be designed and the typo-dimension that fits the subject; in this case access the trousers pattern for boys aged 6 and 8 years old, height $134 \mathrm{~cm}$ (figure 3 ).

Step 5. Select the size that fits the subject and check off the option MTM in the table "Edit set sizes"; select the appropriate size to height 134 and turns in MTM size [3].

Step 6. Replace in the table the necessary dimensions for pattern design, the dimensions taken from the personal protocol of anthropometric measurements (figure 4).

Step 7. Automatically obtain the changed pattern with personal anthropometric measurements.

Step 8. Due to the disposal of the fat tissue on the inner thighs and a deficiency of the lower limbs, the legs tend to sit in an unnatural position, with feet pointing outwards. This causes unsightly folds on the outside of the trousers and a trouser seam upright and inward position. This inconvenience was removed by bowing outward and trouser leg and the seam line change. In figure 5, it can be noticed the difference between the two patterns, the pattern for normal conformation (red) and the one for atypical conformation (blue).

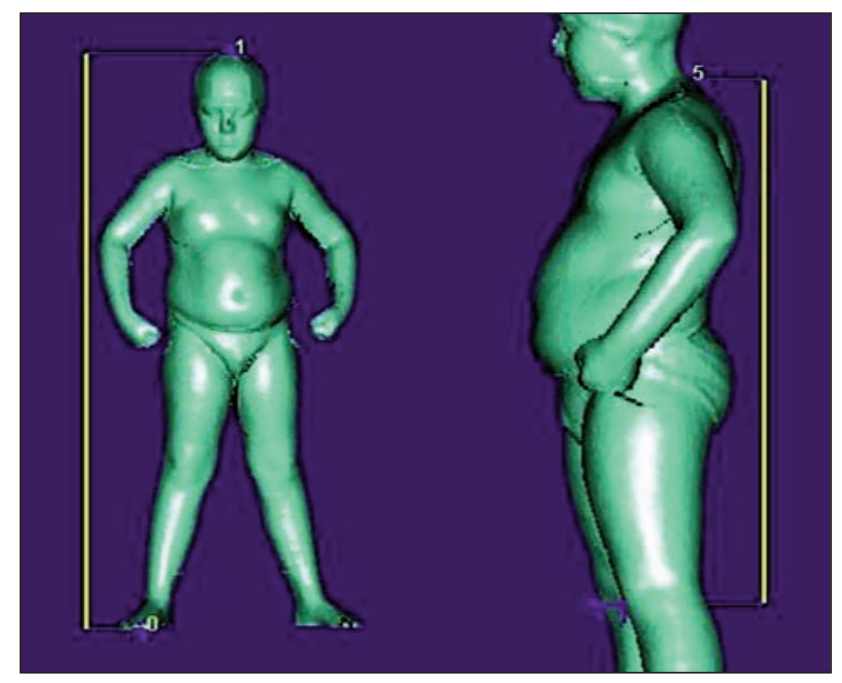

Fig. 2. Atypical change in conformation at the abdomen and lower torso level 


\begin{tabular}{|l|c|c|c|}
\hline \multicolumn{4}{|c|}{ NAME AND SURNAME, GENDER M, AGED 8 YEARS, HEIGHT 134 CM } \\
\hline \multicolumn{1}{|c|}{ Anthropometric size } & $\begin{array}{c}\text { Anthropometric } \\
\text { size code }\end{array}$ & $\begin{array}{c}\text { Standardized } \\
\text { value }\end{array}$ & $\begin{array}{c}\text { Personalized } \\
\text { value }\end{array}$ \\
\hline Body height & 0010 & 134 & 134,5 \\
\hline Waist circumference & 6510 & 60 & 81,4 \\
\hline Maximum hips circumference & 7525 & 72,8 & 85 \\
\hline Hips circumference & 9511 & 40 & 50 \\
\hline Knee circumference & 9521 & 30 & 33 \\
\hline Minimum ankle circumference & 9581 & 17 & 18 \\
\hline The lateral length of the leg (waist to ground) & 9036 & 83,3 & 83 \\
\hline Inner leg length (pubic point to ground) & 9021 & 61,3 & 61 \\
\hline
\end{tabular}

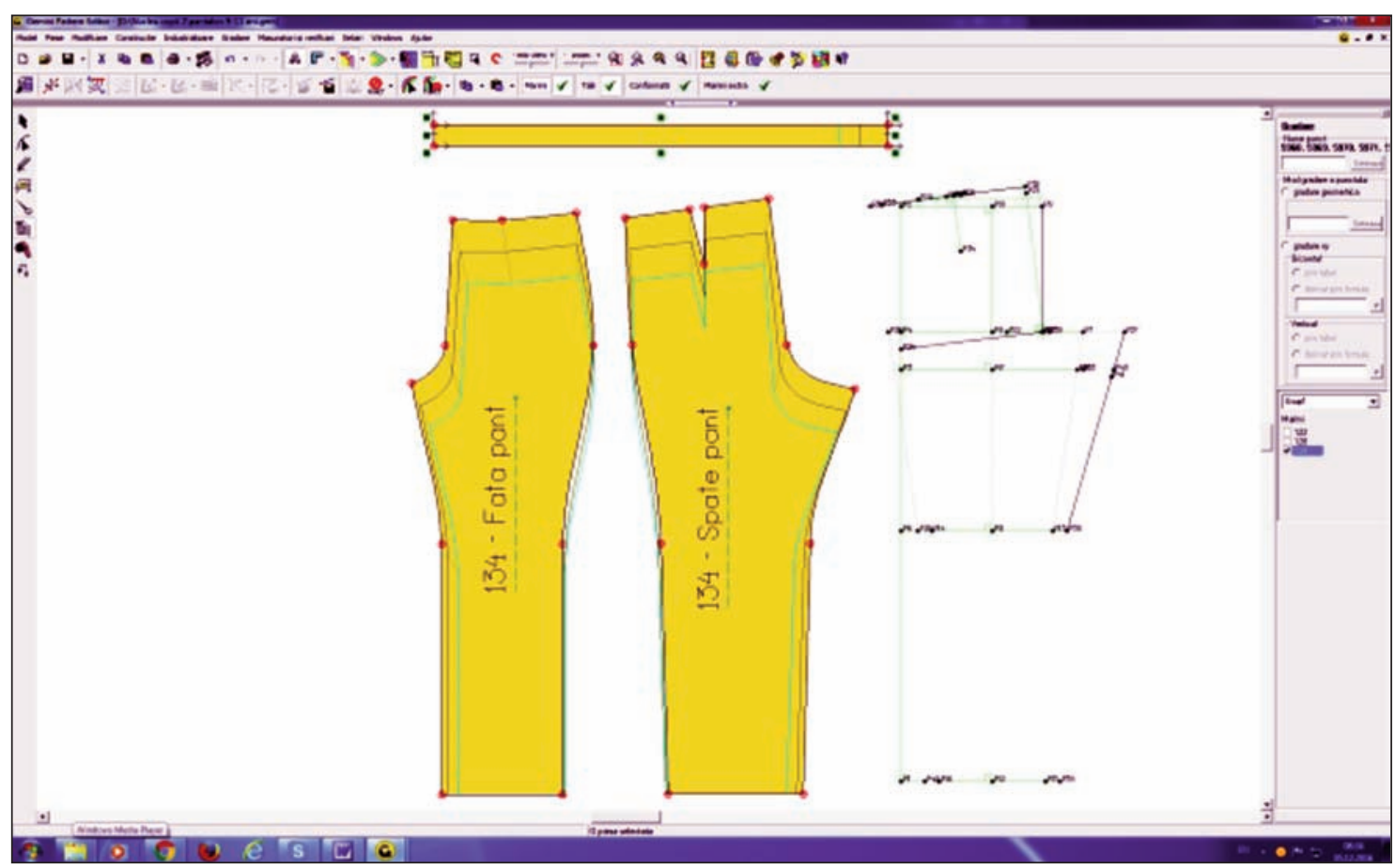

Fig. 3. The basic pattern for trousers boys aged $6-8$ years

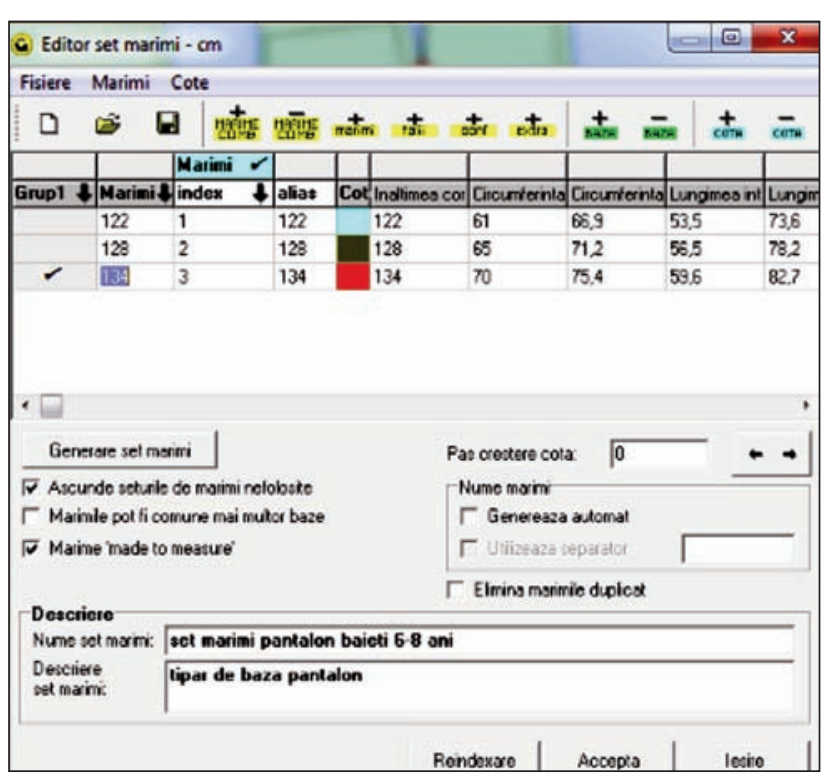

Fig. 4. Entering the personal allowances in the Sizes Editor

\section{RESULTS AND DISCUSSIONS}

Virtual simulation and modeling methodology of clothing products for highlighting the body-product correspondence for children with atypical changes in conformation and posture

The designed product is subject of simulation and modeling on the virtual body in order to analyze the body-product correspondence and the visualization of product draping on the body [4].

Step 1. Import the virtual body from the database resulting from the studied subject body scan in the Optitex-PDS-3D Simulation program.

Step 2. Import the pattern for the customized product from Gemini Made-to-measure design program (figure 6).

Step 3. Identify the clothing product parts in relation to the 3D position and the sewing lines are established.

Step 4. The clothing product parts are positioned on the virtual body (figure 7). 


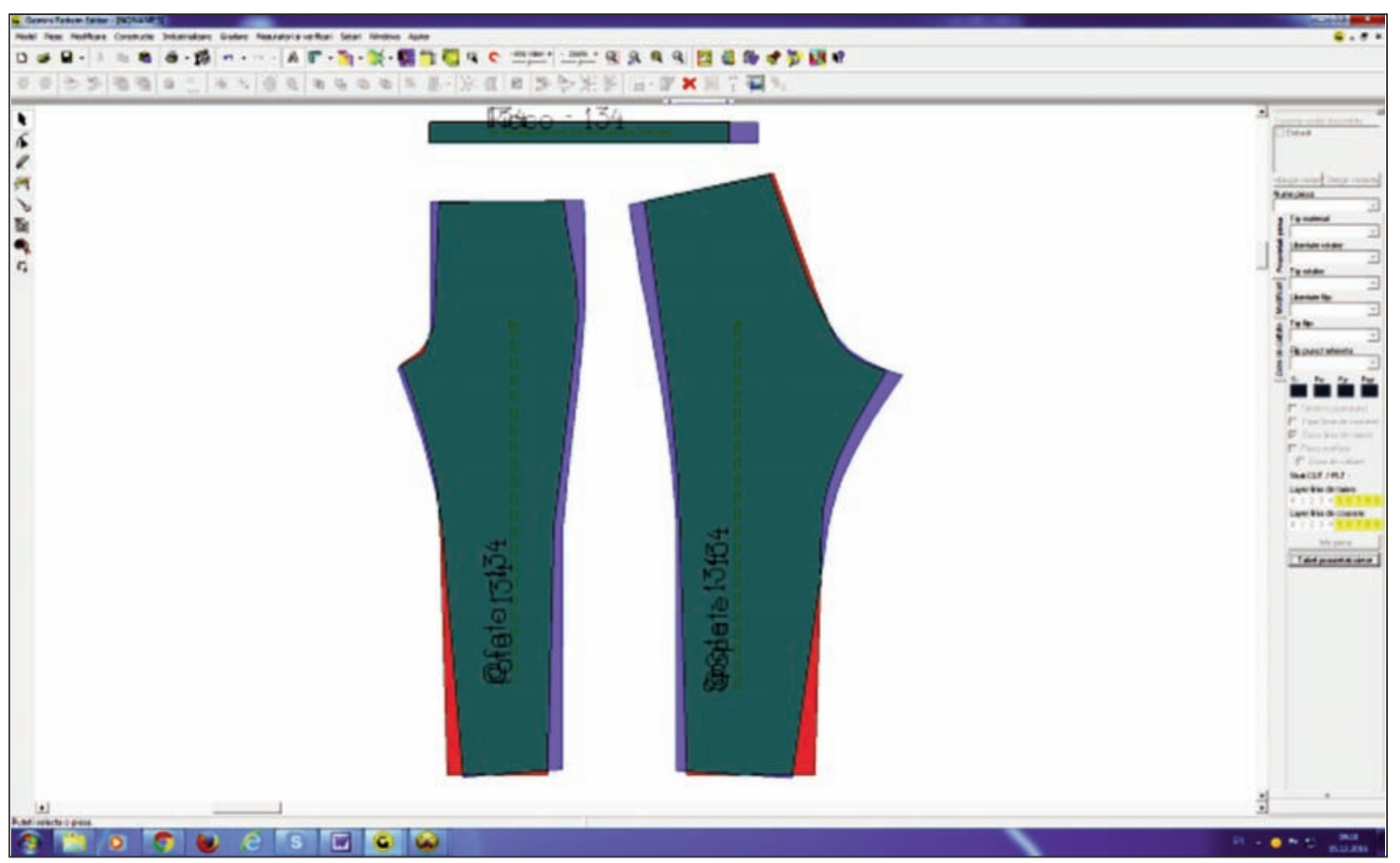

Fig. 5. Customized pattern versus pattern for standard typo-dimension (red)

Step 5. Clothing product simulation processes (figure 8).

Step 6. It assesses the product matching on the body and examines its appear-ance (figure 9).

Step 7. The product modeling is achieved by changing the 2D pattern in the non-compliant area or areas.

Step 8. Resuming from point 4.

From the general observation of the product trousers in the case of atypical change in conformation in the lower torso area, it results that it shows no unsightly folds and the comfort degree is proper, following the tension map for this:

- in hips and thighs level, the blue and green colors are presented, which shows that the product does not create tension in these areas;

- in the abdomen area, the red color appears because it is the support point of the trousers and the near to the body increases.

Subsequently, a suitable product will result in terms of pattern design.

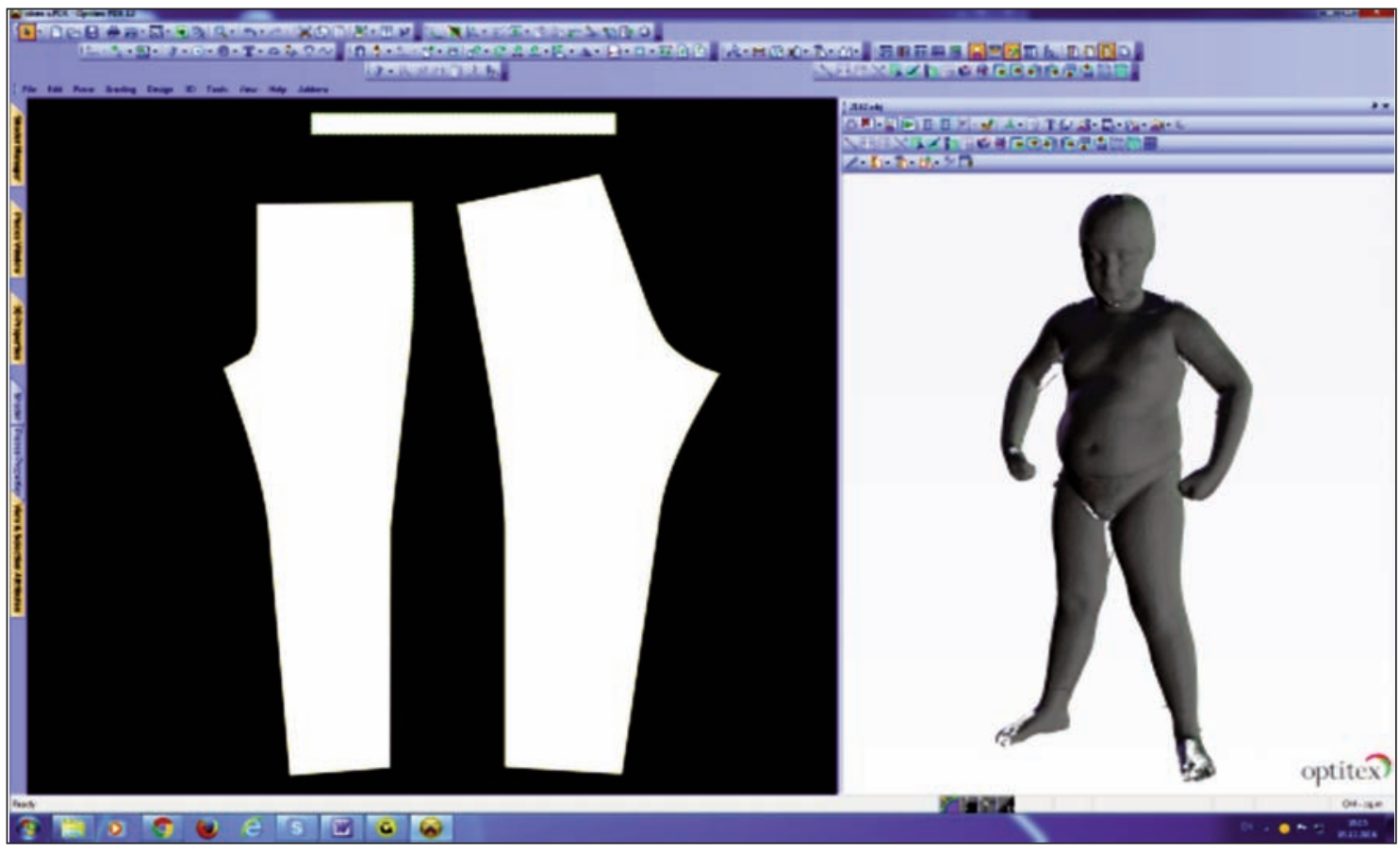

Fig. 6. Importing the virtual body and the designed pattern in the 3D simulation program 


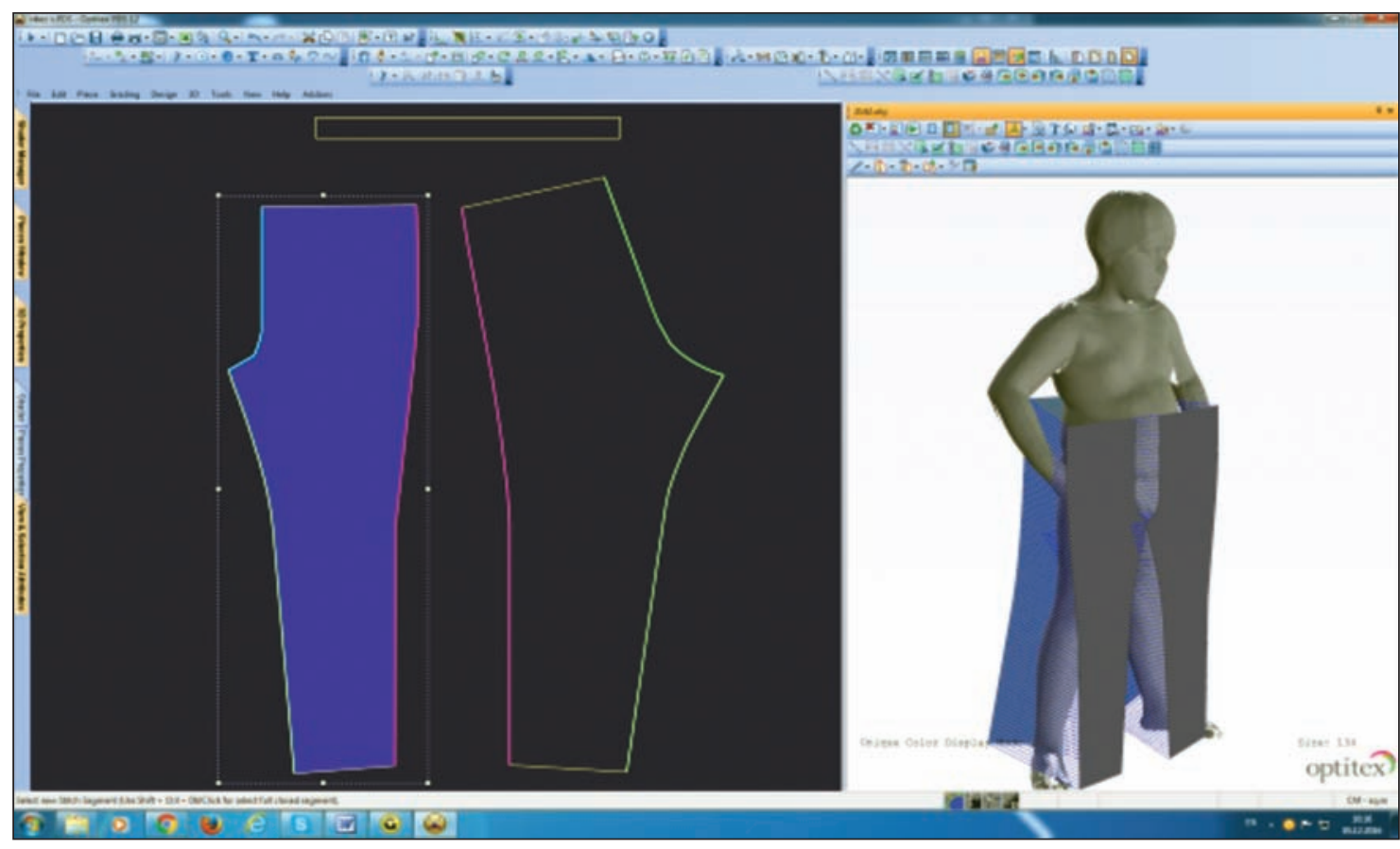

Fig. 7. Positioning the pattern parts on which the seam lines were established

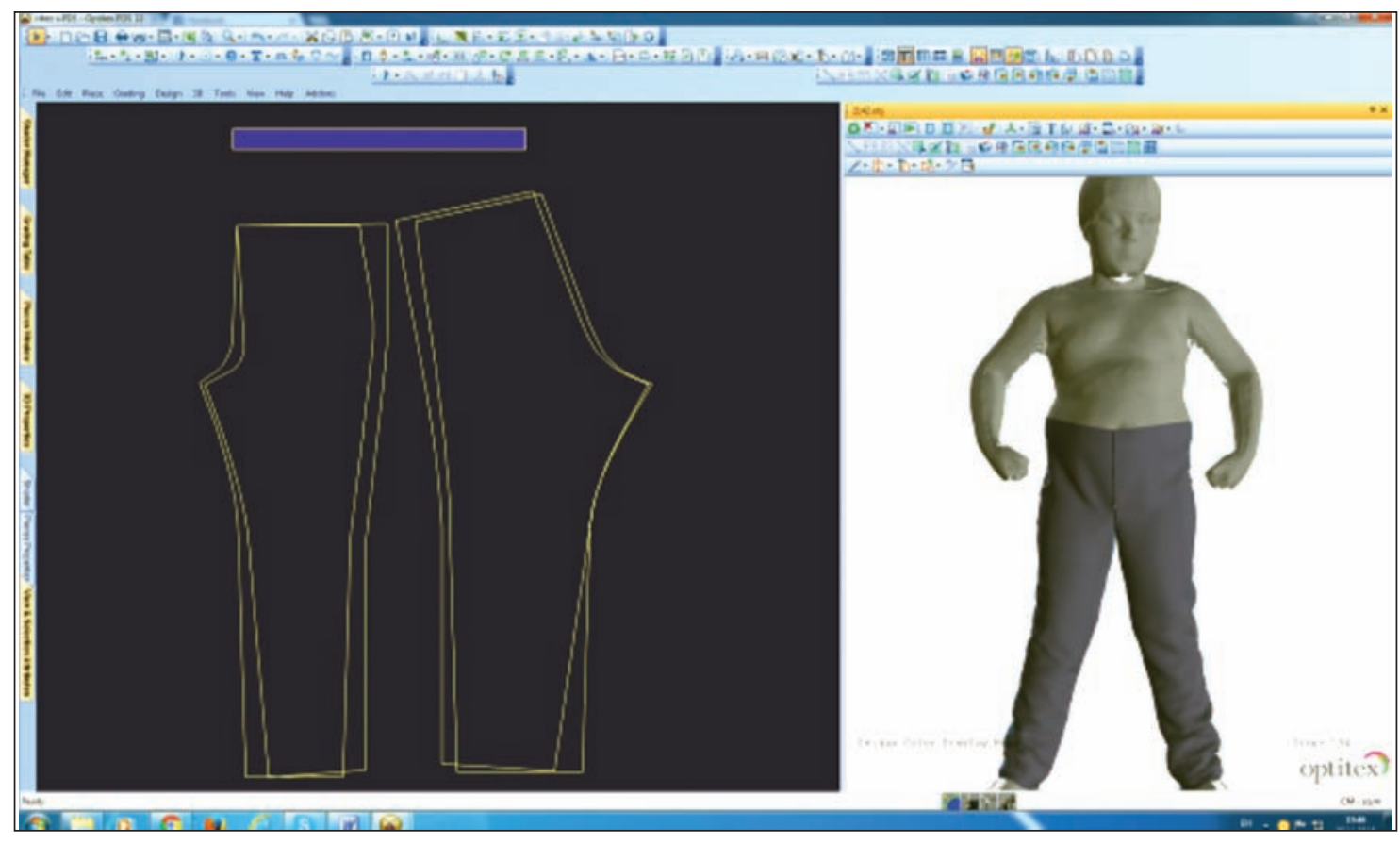

Fig. 8. 3D simulation of the customized trousers for the body with atypical modification in conformation

\section{CONCLUSIONS}

The paper presents the method of designing the basic patterns for clothing products for children with atypical changes in conformation and posture, using anthropometric measurements taken by 3D scanning and the technique of checking the dimensional correspondence body-product by product modelling and simulation on the virtual dummy.

Application of research results will allow the creators and designers of clothing items for children to design products perfectly adapted to their standard sizes and needs as follows:
1. Viewing and analyzing the body deformation directly on the scanned body and to identify ways to adapt clothing products to mitigate defects and increase comfort;

2. Using 3D customized anthropometric dimensions needed in based patterns made-to-measure design for clothing product type;

3. The use of indicators of general characterization of shape and constructive features of clothing products for children with atypical changes in conformation and posture depending on the degree and 


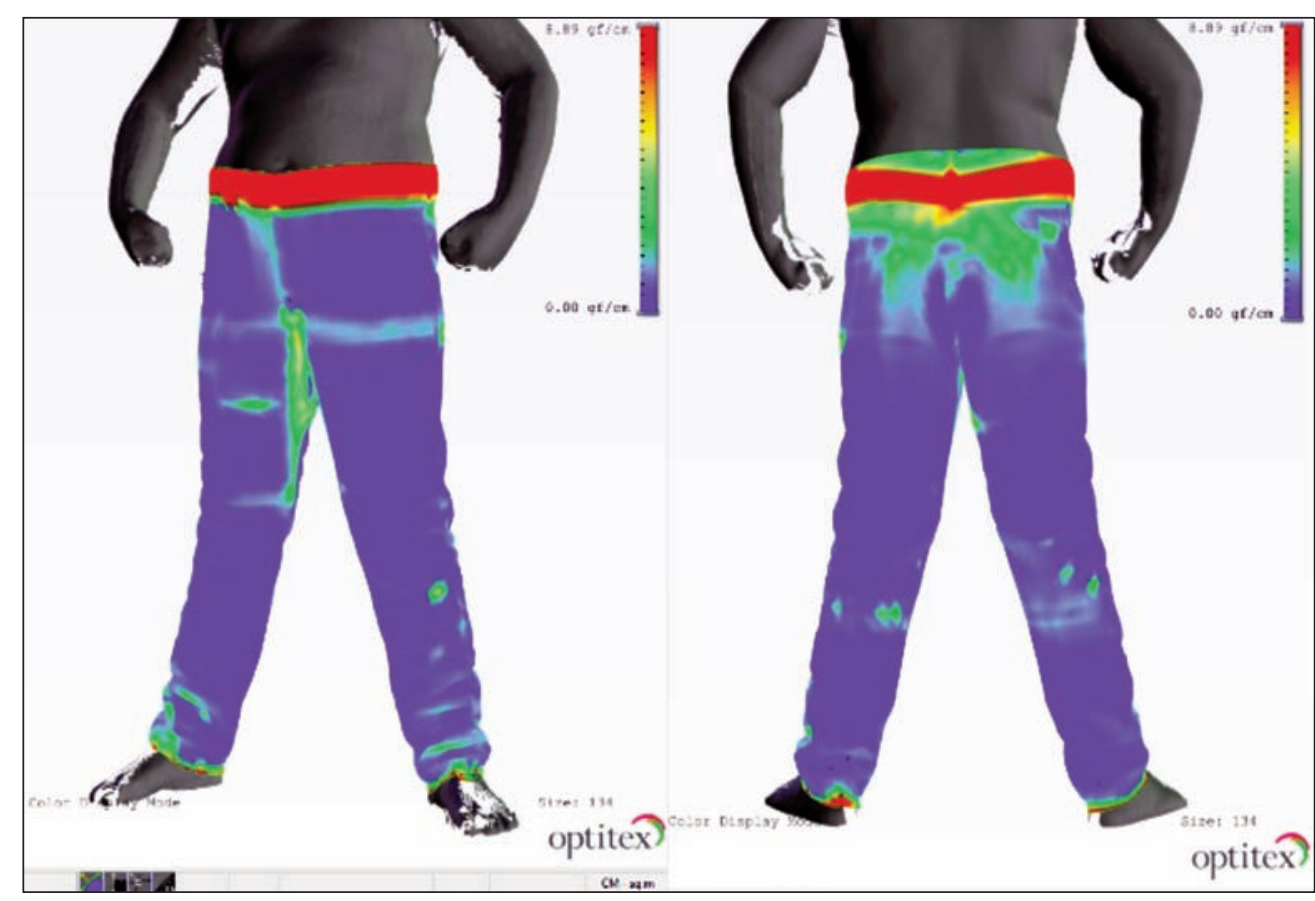

Fig. 9. Simulation of customized trousers for the body with atypical modification in conformation

the deformation of the body, the destination and the type of product;

4. Using the design method of automated basic patterns, according to customized anthropometric dimensions and customized patterns by applying specific design algorithms;

5. Using the 3D Optitex PDS modelling-simulation software of $2 \mathrm{D}$ patterns on virtual body for which the clothing products were designed and the visualization of body-product correspondence on the tension map.

\section{ACKNOWLEDGEMENTS}

This paper was elaborated as part of the Nucleu Program, executed with the support of ANCSI, project no. PN 16340501 .

\section{BIBLIOGRAPHY}

[1] *** Standard SR 13546/2012. Confecții. Dimensiunile corpului pentru copii cu varsta cuprinsă între 6 şi 19 ani

[2] Antonio Donnanno, La tecnica dei modelli, In: Gonne e camicie, Pantaloni e tute, Editura Ikon editrice, Milano

[3] Olaru Sabina, Filipescu Emilia, Avadanei Manuela, Mocenco Alexandra, Popescu Georgeta, Saliștean Adrian, Applied 3D Virtual Try-On for Bodies with Atypical Characteristics, In: revista cotata ISI Procedia Engineering, vol. 70, 2015, ISSN, 1877-7058, pp. 672-681

[4] Emilia Filipescu, Sabina Olaru, Elena Filipescu, Eco-design al îmbrăcămintei prin simularea în spațiul virtual, In: Buletinul AGIR, Supliment 2/2012, pp. 153-159

Authors:

\section{GEORGETA POPESCU \\ CLAUDIA NICULESCU \\ SABINA OLARU}

National R\&D Institute for Textiles and Leather, Bucharest Lucrețiu Pătrășcanu street, no. 16, sector 3, postal code 030508 ,

Bucharest - ROMANIA

e-mail: certex@certex.ro

Corresponding author:

GEORGETA POPESCU

georgeta.popescu@certex.ro 


\title{
Comparison of mechanical properties, hand and tailorability of wool blended fabrics for outerwear clothing
}

\author{
DOI: $10.35530 / I T .068 .01 .1278$
}

\section{REZUMAT - ABSTRACT}

\section{Comparație între proprietățile mecanice, tușeul și capacitatea de croire a țesăturilor din lână în amestec pentru îmbrăcămintea de exterior}

Lucrarea face o comparație între proprietățile mecanice, tușeul și capacitatea de croire a țesăturilor din lână în amestec, pentru îmbrăcămintea de exterior. Țesăturile cu legătură pânză și diagonal cu aceeaşi compoziție fibroasă și desimea firelor de urzeală și bătătură identică au fost testate pe instrumentele KESF-B pentru evaluarea obiectivă a materialelor textile la sarcini mici. Proprietățile mecanice ale țesăturii cu legătură pânză și diagonal evidențiază diferențe la încovoiere, forfecare și în proprietățile de suprafață. Țesătura cu legătură pânză are o rezistență la forfecare și o rugozitate a suprafeței mai mare decât țesătura cu legătură diagonal. Legătura diagonal are o rezistență la încovoiere, un histerezis și o energie de compresie mai mare. Diferența dintre tușeul primar selectat și tușeul total a influențat în mare măsură selecția țesăturilor pentru costumele de vară sau iarnă. Ambele tipuri de țesături investigate au prezentat performanțe similare ale capacității de coasere, având aceiași parametri de diagramă a capacității de croire în afara zonei de control.

Cuvinte-cheie: evaluarea obiectivă a țesăturii, tușeul țesăturii, capacitatea de croire, legătura țesăturii

\section{Comparison of mechanical properties, hand and tailorability of wool blended fabrics for outerwear clothing}

The paper compares mechanical properties, hand and tailorability of the wool blended fabrics for outerwear clothing. The fabrics in plain and twill weave of identical fibre composition, and identical warp and weft count were tested on KESF-B instruments for fabric objective evaluation under small loads. Mechanical properties of plain and twill weave fabric shows difference in bending, shearing and surface properties. The plain weave fabric has higher shearing strength and surface roughness than twill weave. Twill weave obtains higher bending strength, bending hysteresis and compression energy. The difference in selected primary hands and total hand greatly influenced selection of fabrics for summer or winter suits. Both investigated fabrics showed similar sewability performance, having same parameters of tailorability chart out of control zone.

Keywords: fabric objective evaluation, fabric hand, tailorability, fabric weave

\section{INTRODUCTION}

The phenomena of fabrics hand is one of the most significant characteristics in determining fabric marketing, and defining scope of fabric end-use performance.

Applications of objective measurements in fabric evaluation, quality assurance in garment making and product design were suggested by Postle, Kawabata and other researchers [1-2]. Kim et al. investigated the garment performance and mechanical properties of thin worsted fabrics under various wet processing conditions and finishing processes [3]. The effect of wet scouring in wet finishing and dry finishing on crease recovery, formability, drape and hand were studied. They also evaluated instrumental methods for measuring the surface frictional properties of six fabrics finished with different softeners [4]. Robinson et al. reported the influence of pattern design and fabric type on the hand characteristics of pigment prints [5]. Results showed that fabric and pigment type had a greater influence on hand characteristics that the pattern designs. Anon investigated the effect of softeners in pigment printing [6]. The softener based on a silicone micro emulsion provided more stable films with improved elasticity, which reflected in fabric hand. Mukhopadhyay measured KESF characteristics of eight fabric groups structured by fiber content, fabric construction and special finishing treatment by the KES-F system [7]. He found that fabric construction has some influence on fabric stiffness, but not on hysteresis. Polyester-lining fabrics have high bending stiffness and polyester/cotton fabrics have high shear stiffness and hysteresis. Matsudaira and Matsui followed the changes of mechanical properties and fabric hand of polyester fabrics through wet processing and the finishing stages [8]. Balci and Gençer investigated the necessity of the cellulase enzyme application for cotton based woven fabrics [9]. They found out that the sequence, before or after dyeing, of application of cellulase enzyme treatment especially affected the handle properties. Geršak investigation was aimed to clarify the influence of fabric mechanical behavior on form changes, as well as on the impact of particular fabric mechanical properties on garment appearance quality [10]. The results indicated high correlation between garment appearance quality and formability, 
INVESTIGATED FABRIC PARTICULARS

\begin{tabular}{|c|c|c|c|c|c|c|}
\hline \multirow{2}{*}{$\begin{array}{c}\text { Fabric } \\
\text { weave }\end{array}$} & \multicolumn{2}{|c|}{ Yarn count, tex } & \multirow{2}{*}{ Turns, $\mathbf{m}^{-1}$} & \multicolumn{2}{|c|}{ Thread density, $\mathbf{c m}^{\mathbf{- 1}}$} & \multirow{2}{*}{\begin{tabular}{c} 
Fabric weight, \\
\cline { 5 - 6 }
\end{tabular}} \\
\cline { 2 - 3 } & warp & weft & & warp & weft & \\
\hline Plain & $18 \times 2$ & $18 \times 2$ & Z700/S700 & 29.0 & 20.0 & 200 \\
\hline Twill & $18 \times 2$ & $18 \times 2$ & Z700/S700 & 35.4 & 24.4 & 250 \\
\hline
\end{tabular}

elastic potential and draping. Tsucada et al. shown that the changes in tensile, shearing, bending and compression behavior of grafted wool fabrics are due to the reduction of the free internal volumes of the fabrics, leading to a tightening of its texture [11]. A comparative study has been carried out to evaluate the performance of jeans and trousers produced by low-torque yarns to conventional ring and rotor yarns [12]. The results from the objective measurements of fabric performance indicated that compared to the fabrics produced from conventional ring and rotor yarns, the low-torque ring yarn fabrics exhibit higher compression energy (WC), lower mean deviation of friction (MMD) and higher values of Numeri and Fukurami. Behera and Pattanayak investigated the measurement of drape of apparel fabric by using digital image processing [13]. In the study, bending rigidity, tensile, shear and compressional properties of fabrics were also measured by KES system. In our previous paper we investigated the effect of fabric structure variation on fabric water vapour permeability and air permeability properties and bending and drapes properties [14-15].

The aim of this paper is to investigate the effect of fabric weave on primary, total hand and tailorability of fabrics for outerwear clothing.

\section{EXPERIMENTAL WORK}

\section{Materials and method}

The fabrics investigated are wool/PES/Lycra woven fabrics of the same fibre composition, yarn count and turns. The fabrics designated have all structure parameters identical and differ in weave. The samples particulars are depicted in table 1.

The samples are tested on KES-FB system for mechanical properties under low load. The system and consists of: KES-F1 for tensile and shearing testing, KES-F2 for bending testing, KES-F3 for compression testing, and KES-F4 for investigating surface friction [16-19]. The system provides total of 16 properties measured at low loads. Before testing, the samples were conditioned under standard atmospherics conditions, $20 \pm 2{ }^{\circ} \mathrm{C}$ and $65 \pm 2 \%$ relative humidity. The measurements are then transformed into primary hand values and total hand values for winter and summer suiting fabrics.

\section{RESULTS AND DISCUSSION}

The results of KESF mechanical properties of the investigated fabrics are presented in table 2.

Comparison of tensile properties of plain and twill fabric shows that the differences are more prominent in warp and weft directions. The greatest differences are found in fabric extensibility. In warp direction, plain fabric has $29.3 \%$ higher extensibility than twill (4.53 to $3.2 \%$ ). Opposite to that, in weft direction, plain fabric has lower extensibility for $26.7 \%$ (14.83\% to $18.78 \%$ ). Figure 1 shows tensile extension properties of one of plain and twill tested sample.

Plain fabric compared to twill has all bending properties in all directions substantially lower. The more significant change occurs in weft direction where plain has lower $\mathrm{B}$ and $2 \mathrm{HB}$ for $43.5 \%$ and $77.2 \%$ respectively (table 3 ). In warp direction the plain fabric has also lower $\mathrm{B}$ and $2 \mathrm{HB}$ for $15.6 \%$ and $39.2 \%$. Plain fabric has lower warp and weft density and fabric weight, which results in lower bending stiffness. Although plain one has lower thread density in both directions in relation to twill for the same percentage $(22 \%)$, the substantial lower bending rigidity and hysteresis compared to twill is in weft direction. Higher thread density of twill fabric contributes to higher bending stiffness. On the other hand, plain weave is

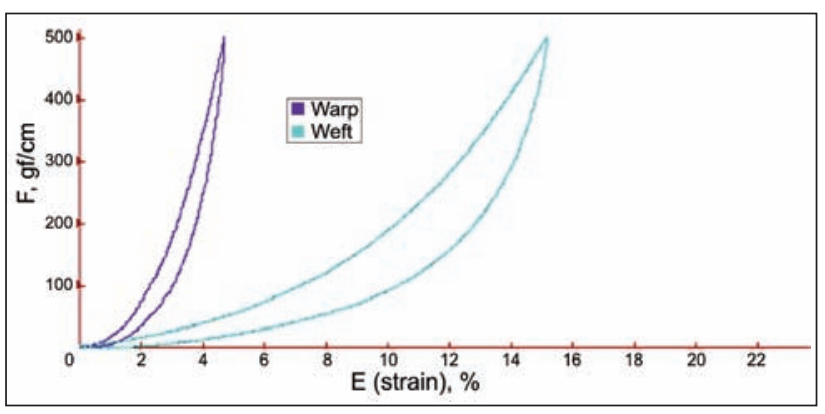

a

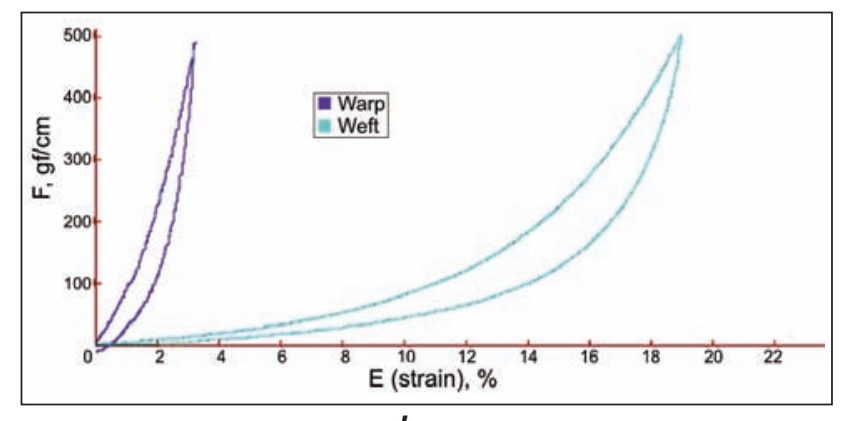

b

Fig. 1. Tensile properties fabrics by warp and weft: $a-$ Plain and $b-$ Twill 


\begin{tabular}{|c|c|c|c|c|c|c|}
\hline \multicolumn{7}{|c|}{ MECHANICAL PROPERTIES UNDER LOW LOADS OF PLAIN AND TWILL WEAVE FABRIC } \\
\hline \multirow{2}{*}{ Properties } & \multicolumn{3}{|c|}{ Plain } & \multicolumn{3}{|c|}{ Twill } \\
\hline & Warp & Weft & Average & Warp & Weft & Average \\
\hline \multicolumn{7}{|l|}{ Tensile } \\
\hline EM [\%] & 4.526 & 14.828 & 9.677 & 3.198 & 18.780 & 10.989 \\
\hline LT [-] & 0.613 & 0.598 & 0.606 & 0.746 & 0.514 & 0.630 \\
\hline WT $\left[\mathrm{cN} \cdot \mathrm{cm} / \mathrm{cm}^{2}\right]$ & 6.930 & 22.190 & 14.560 & 5.970 & 24.130 & 15.050 \\
\hline RT [\%] & 65.650 & 63.270 & 64.460 & 57.860 & 62.070 & 59.965 \\
\hline \multicolumn{7}{|l|}{ Bending } \\
\hline $\mathrm{B}\left[\mathrm{cN} \cdot \mathrm{cm}^{2 /} \mathrm{cm}\right]$ & 0.077 & 0.131 & 0.104 & 0.089 & 0.188 & 0.139 \\
\hline $2 \mathrm{HB}[\mathrm{cN} \cdot \mathrm{cm} / \mathrm{cm}]$ & 0.029 & 0.054 & 0.041 & 0.040 & 0.096 & 0.068 \\
\hline \multicolumn{7}{|l|}{ Shearing } \\
\hline $\mathrm{G}\left[\mathrm{cN} /\left(\mathrm{cm}^{0}\right)^{1}\right]$ & 1.143 & 1.634 & 1.388 & 0.820 & 1.258 & 1.039 \\
\hline $2 \mathrm{HG}[\mathrm{cN} / \mathrm{cm}]$ & 0.773 & 1.345 & 1.059 & 0.751 & 1.587 & 1.169 \\
\hline $2 \mathrm{HG} 5[\mathrm{cN} / \mathrm{cm}]$ & 3.010 & 3.110 & 3.060 & 2.370 & 2.980 & 2.675 \\
\hline \multicolumn{7}{|l|}{ Surface } \\
\hline MIU [-] & 0.109 & 0.094 & 0.102 & 0.107 & 0.099 & 0.103 \\
\hline MMD [-] & 0.058 & 0.035 & 0.046 & 0.016 & 0.017 & 0.017 \\
\hline SMD $[\mu \mathrm{m}]$ & 13.024 & 8.687 & 10.856 & 3.675 & 4.107 & 3.891 \\
\hline \multicolumn{7}{|l|}{ Compression } \\
\hline LC [-] & & - & 0.271 & & - & 0.285 \\
\hline $\mathrm{WC}\left[\mathrm{cN} \cdot \mathrm{cm} / \mathrm{cm}^{2}\right]$ & & - & 0.101 & & - & 0.123 \\
\hline $\mathrm{RC}[\%]$ & & - & 55.267 & & - & 56.761 \\
\hline
\end{tabular}

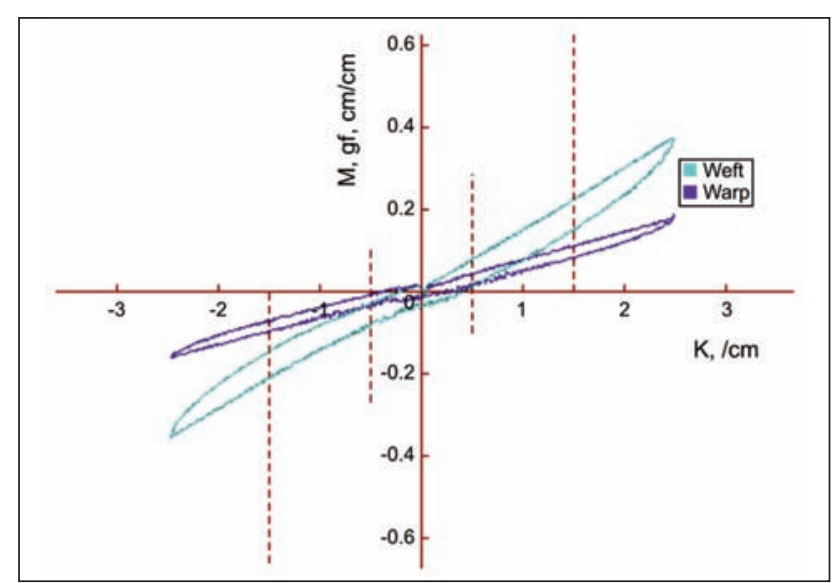

a

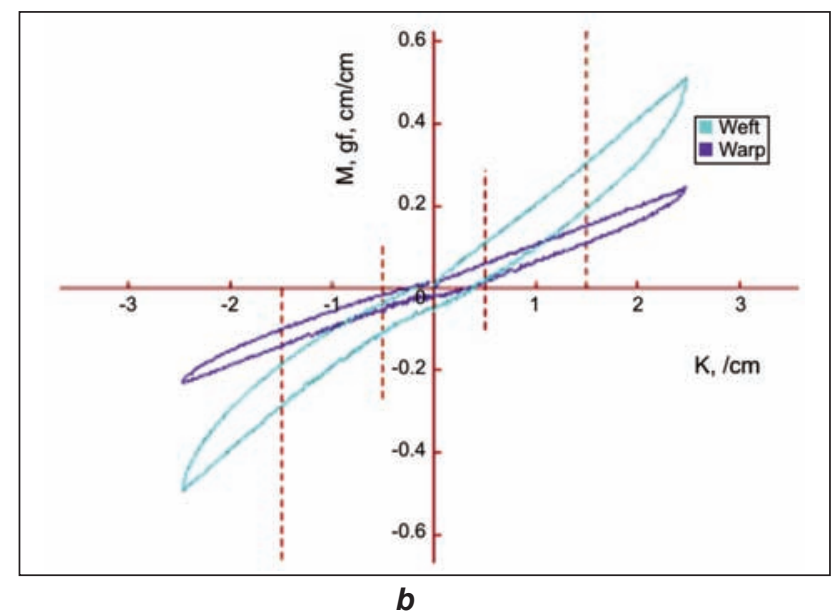

Fig. 2. Bending properties by warp and weft: $a-$ Plain and $b-$ Twill

more closed weave and gives higher rigidity than twill if the fabrics have the same cover factor. In this case, twill fabric has higher cover factor which explains its higher bending rigidity. Figure 2 shows the comparison of bending rigidity properties of one of plain twill tested samples.

Analysis of the shear properties shows that the plain fabric has significantly higher values of shear stiffness. Plain fabric obtains higher shear rigidity than twill for $28.2 \%$ and $23 \%$ in warp and weft directions. Plain one has also considerable higher value of hysteresis of shear force $2 \mathrm{HG} 5$ in warp direction $(21.3 \%)$. The higher shear stiffness of plain fabric compared to twill is a result of the type deformation which occurs at shear, i.e. rotation and displacement the one thread system over another. The plain weave compared to twill has greater number connective points, or less float, and the movement of one thread system over another is more difficult which consequently increases shearing rigidity. Figure 3 shows the comparison of shear rigidity properties of one plain twill tested samples.

Regarding the surface properties, especially large differences between plain and twill fabric occurs in the geometrical roughness (SMD) and mean deviation of coefficient of friction (MMD). Fabric in plain 

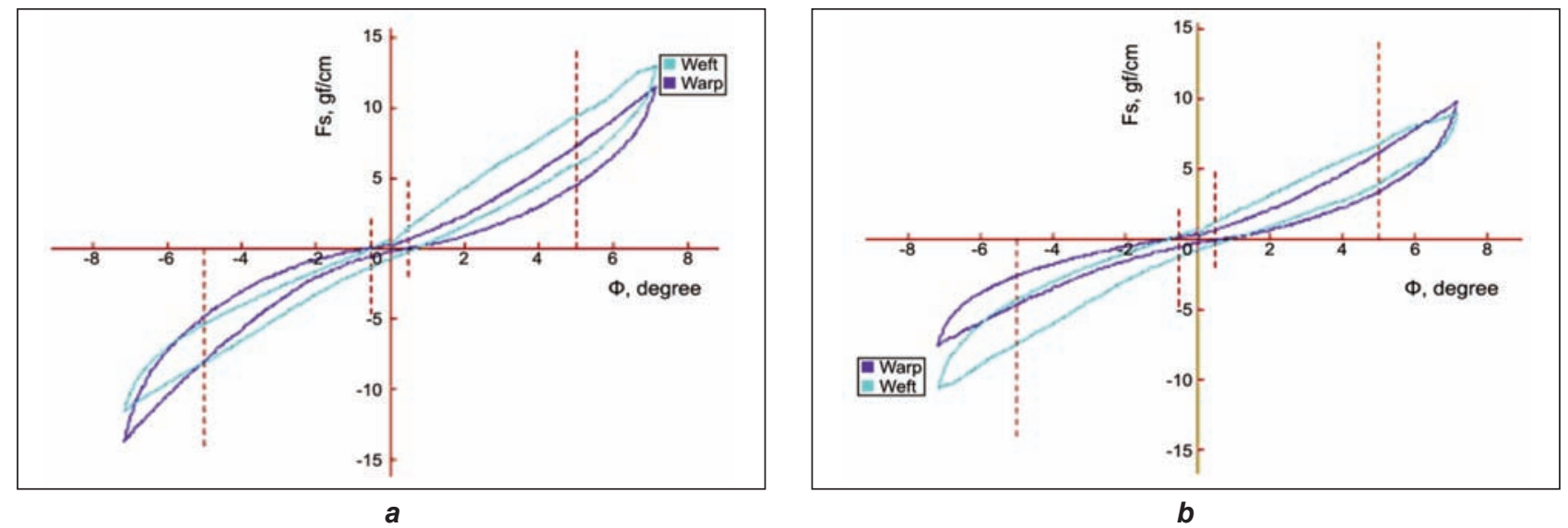

Fig. 3. Shear properties by warp and weft: $a-$ Plain and $b-$ Twill
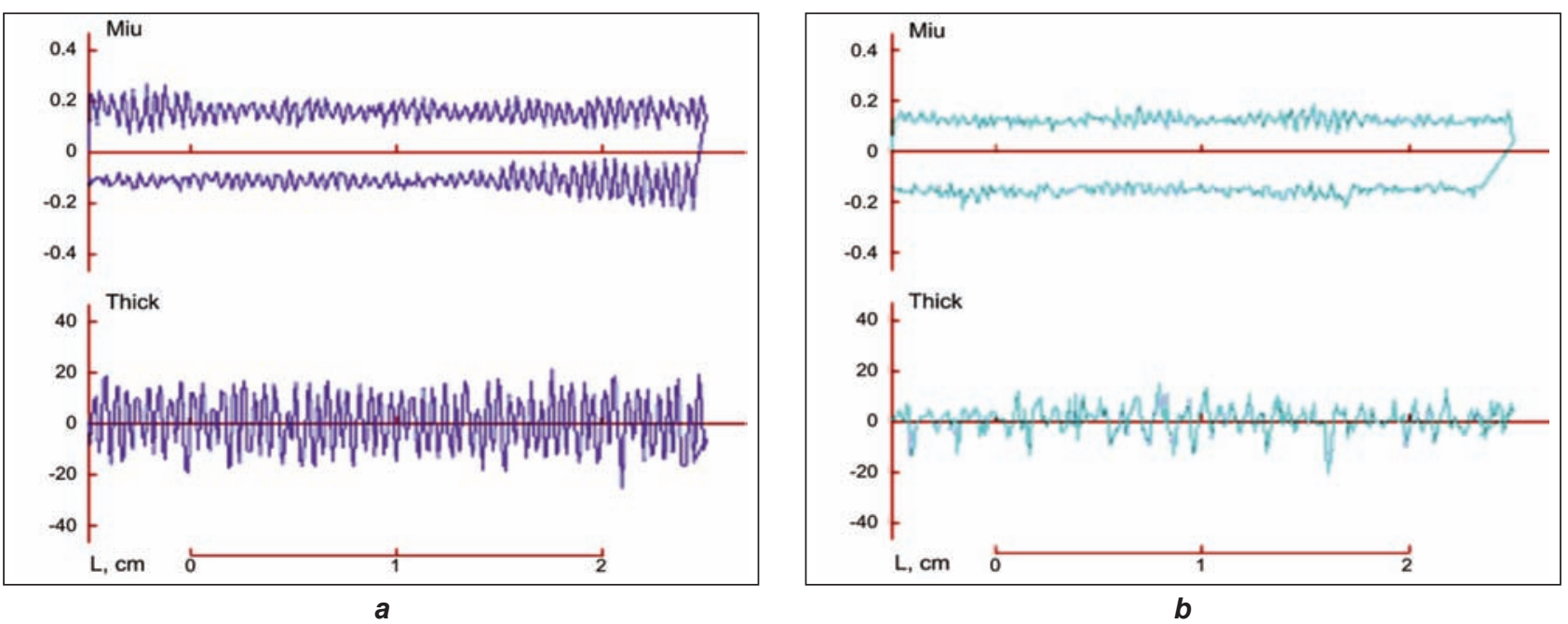

Fig. 4. Coefficient of friction MIU and geometrical roughness SMD of plain fabric in: $a$ - warp direction and $b-$ weft direction

weave has SMD and MMD values in all directions significantly higher compared to twill fabric: geometrical roughness is higher for $71.8 \%$ and $52.7 \%$ in warp and weft direction respectively. Also, plain fabric has higher deviation of coefficient of friction: $72.1 \%$ by warp and $50.7 \%$ by weft. The great difference in values can be a great contribution of weave, since plain weave having lower thread floating and higher crimp, obtains higher surface roughness. The difference in surface properties between the two fabrics can be clearly noticed on the graphs of coefficient of friction and geometrical roughness (figure $4, a$ and $b$, figure $5, a$ and $b$ ). It is also noticeable that the difference in geometrical roughness between two fabrics is more pronounced in warp direction.

Regarding the compression properties, the plain fabric obtains lower compression energy than twill for $21.9 \%$.

Primary and total hand value - THV of investigated fabrics for men's winter and summer suit are given in table 3 for plain and twill fabric.

\begin{tabular}{|c|c|c|c|c|c|}
\hline \multicolumn{6}{|c|}{$\begin{array}{l}\text { PRIMARY AND TOTAL HAND VALUE FOR MEN`S WINTER AND MEN`S SUMMER-SUIT FABRICS, } \\
\text { PLAIN AND TWILL WEAVE FABRICS }\end{array}$} \\
\hline \multicolumn{3}{|c|}{ Men's Winter-suit fabrics } & \multicolumn{3}{|c|}{ Men's Summer-suit fabrics } \\
\hline Primary hand & Plain & Twill & Primary hand & Plain & Twill \\
\hline KOSHI & 6.12 & 5.97 & KOSHI & 6.75 & 6.65 \\
\hline NUMERI & 0.93 & 5.01 & SHARI & 7.52 & 3.81 \\
\hline \multirow[t]{2}{*}{ FUKURAMI } & 1.18 & 4.42 & FUKURAMI & 4.53 & 5.25 \\
\hline & & & HARI & 7.6 & 7.52 \\
\hline THV & 1.34 & 3.22 & THV & 3.75 & 2.62 \\
\hline
\end{tabular}



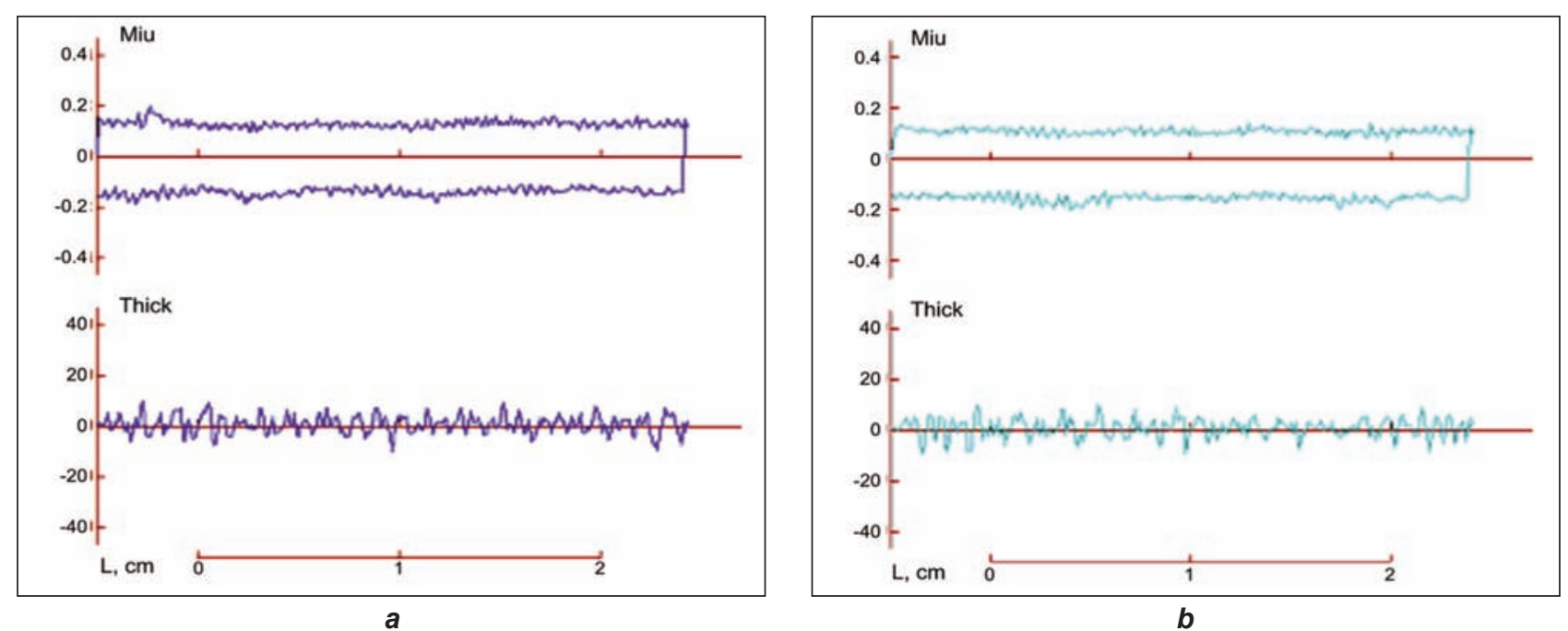

Fig. 5. Coefficient of friction MIU and geometrical roughness SMD of twill fabric in: $a$ - warp direction and $b$ - weft direction

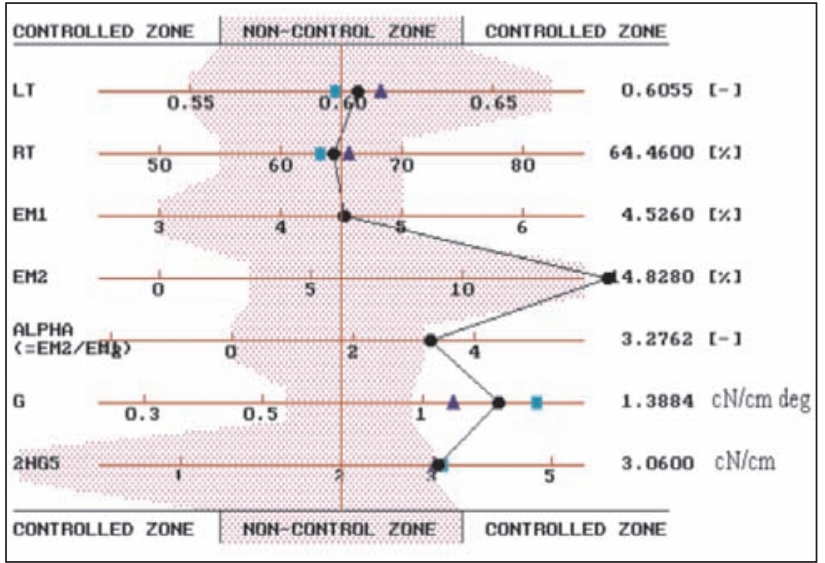

a

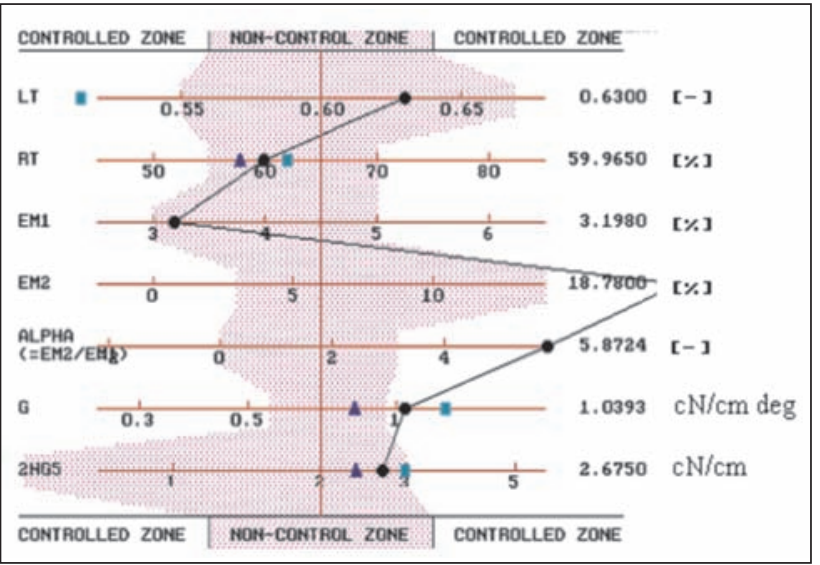

b

Fig. 6. Tailorability chart for plain (a) and twill (b) fabrics

Regarding hand properties for winter suits, there is great difference between plain and twill fabric. Plain fabric has very low THV of 1.34, while twill high value of 3.22. This is a result of differences in primary hand values of (Numeri) and fullness (Fukurami). Plain fabric has low Numeri (0.93) and Fukurami (1.18). On the contrary, twill has much higher values of Numeri (5.01) and Fukurami (4.42). Smoothness and Fullness of the fabric has great influence to total hand. Otherwise, higher value for (Fukurami) fullness is a result of $21.0 \%$ higher work of compression for twill fabric compared to plain fabric. Higher value for smoothness is a result of lower geometrical roughness for twill fabric compared to plain fabric. Results favour twill fabric as much better choice for winter suits.

Regarding hand properties for summer suits, there is great difference between plain and twill fabric in primary hand of Shari i.e. crispness of the fabric. The very high value of Shari results in very high THV of 3.75 for plain fabric. Results favour plain fabric for being much better choice for summer suit compared to twill fabric.
Figure 6 represents tailorability charts for investigated fabrics. Both fabrics have the same parameters EM2, a and $G$ out of the control zone. Twill fabric has somewhat greater value of EM2 (18.78\%) and a (5.8724) out of control zone compared to plain fabric, suggesting larger possible sewing problems when sewing with fullness and appearance of seam pucker. Only plain weave has 2 HG5 value slightly out of control zone, indicating possible problems in sewing operations with overfeed.

\section{CONCLUSIONS}

Comparison of KESF mechanical properties, between plain and weave fabric of identical fiber composition and warp and weft count, has shown differences between two fabrics in bending, shearing, surface and compression properties.

Compared to twill fabric, the plain fabric has higher shearing strength and hysteresis, geometrical roughness (SMD) and mean deviation of coefficient of friction (MMD). The twill fabric has higher values of bending strength, bending hysteresis and compression 
energy. Plain fabric has higher tensile strength in warp direction, while twill fabric in weft direction. Comparison of primary and total hand values of both fabrics shows great influence of weave on hand properties. Higher values of Numeri, Fukurami and Total Hand for twill weave, favouring twill fabric as better choice for winter-suits. Much higher values of Shari for plain fabric, as well as higher Total hand, favors this fabric as much better choice for summer-suit. The both plain and twill fabric have most values of tailorability chart in safe zone. Values EM2, a and G are out of the control zone for both fabrics. Only plain fabric has the parameter $2 \mathrm{HG} 5$ slightly out of the control zone, indicating potential sewing problems in sewing with overfeed.

\section{BIBLIOGRAPHY}

[1] Postle, R., Mahar, T. J. Basic Requirements for an International Objective Measurements Programme for Wool Fabric Quality, In: The Textile Machinery Society of Japan, Osaka, Japan 1982, pp. 1-22

[2] Postle, R., Kawabata, S., Niwa, M. Objective Evaluation of Apparel Fabrics, In: Textile Machinery Society of Japan, Osaka, Japan 1983

[3] Kim, S. J., Lee, D. H., Min, S., Bae, K. H. Effect of finishing process on physical properties of the thin worsted fabrics, In: Proceedings $77^{\text {th }}$ World Conference of the Textile Institute, Niches in the World of Textiles, 1997, vol. 2, no. 2, pp. 203

[4] Kim, J. J., Hamouda, H., Shalev, I., Barker, R. L. Instrumental methods for measuring the surface frictional properties of softener treated fabrics, In: Textile Chemist and Colorist, 1993, vol. 25, no. 8, pp. 15-20

[5] Robinson, K. L., Chambers, E., Gatewood, B. M. Influence of pattern design and fabric type on the hand characteristics of pigment prints, In: Textile Research Journal, 1997, vol. 67, no. 11, pp. 837-845

[6] Anon, Softeners in pigment printing, In: Textile, 1995, vol. 44, no. 8, p. 355

[7] Gong, R. H., Mukhopadhay, S. K. Fabric objective measurement: a comparative study of fabric characteristics, In: Journal of the Textile Institute, 1993, vol. 84, no. 2, pp. 192-198

[8] Matsudaira, M., Matsui, M. Changes in the mechanical properties and fabric handle of polyester-fiber through the finishing stages, In: Journal of the Textile Institute, 1992, vol. 83, no. 1, pp. 144-155

[9] Balci, O., Gençer, U. Cellulase enzyme application for the cotton based woven fabrics, Part II. The determining of necessity and cellulase enzyme application sequence in the finishing process, In: Industria Textila, 2013, vol. 64, no. 2, pp. 80-88

[10] Geršak, J. Investigation of the impact of fabric mechanical properties on garment appearance, In: Tekstil, 2003 , vol. 52, no. 8, pp. 368-379

[11] Tsukada, M., Khan, M. M. R., Miura, T., Postle, R., Sakaguchi, A. Mechanical performance of wool fabrics grafted with methacrylamide and 2-hydroxyethyl methacrylate by the Kawabata Evaluation System for Fabric method, In: Textile Research Journal, 2013, vol. 83, no. 12, pp. 1242-1250

[12] Hua, T., Tao, X. M., Cheng, K. P. S. Comparative study on appearance and performance of garments made from low-torque ring, conventional ring and open-end spun yarn fabrics using subjective and objective evaluation methods, In: Textile Research Journal, 2014, vol. 84, no. 13, pp. 1345-1360

[13] Pan, R., Zhu, B., Li, Z., Liu, J., Gao, W. A. K. A simulation method of plain fabric texture for image analysis, In: Industria Textila, 2015, vol. 55, no. 1, pp. 28-31

[14] Nofitoska, M., Demboski, G., Ćortoševa, S. Influence of fabric structure parameters on the water vapor and air permeability, In: Tekstil, 2011, vol. 60, no. 8, pp. 376-383

[15] Nofitoska, M., Demboski, G., Carvalho, M. Â. F. Effect of Fabric Structure Variation on Garment Aesthetic Properties, In: Tekstil ve Konfeksiyon, 2012, vol. 22, no. 2, pp. 132-136

[16] Manual for Tensile and Shear Tester KES-FB-1, Kyoto, Japan: KATO Tech Co., Ltd.

[17] Manual for Pure Bending Tester KES-FB-2, Kyoto, Japan: KATO Tech Co., Ltd.

[18] Manual for Compression Tester KES-FB-3, Kyoto, Japan: KATO Tech Co., Ltd.

[19] Manual for Surface Tester KES-FB-4, Kyoto, Japan: KATO Tech Co., Ltd.

\section{Authors:}

\section{Assistant prof. dr. MAJA JANKOSKA}

Prof. dr. GORAN DEMBOSKI

University "Ss. Cyril and Methodius", Skopje

Faculty of Technology and Metallurgy, Department of Textile Engineering

Str. Rudjer Boskovic no.16, 1000 Skopje, Macedonia

Corresponding author:

MAJA JANKOSKA

maja@tmf.ukim.edu.mk 